Kemenszky Ágnes:

A nemzetközi területi adminisztráció balkáni modelljei: Bosznia-Hercegovina és Koszovó 
Nemzetközi Tanulmányok Intézet

Témavezető:

Dr. Rostoványi Zsolt

egyetemi tanár

A bíráló bizottság névsora:

CKemenszky Ágnes 
Budapesti Corvinus Egyetem

Nemzetközi Kapcsolatok Multidiszciplináris Doktori Iskola

\section{A nemzetközi területi adminisztráció balkáni modelljei: \\ Bosznia-Hercegovina és Koszovó}

Ph.D. értekezés

Kemenszky Ágnes

Budapest, 2012 
Bokorné Szegő Hannának 


\section{TARTALOMJEGYZÉK}

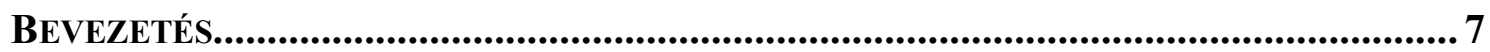

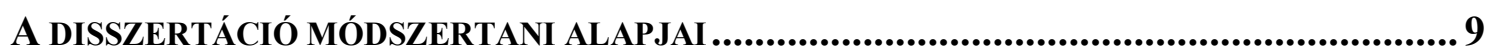

1. A NEMZETKÖZI TERÜLETI IGAZGATÁS ELMÉLETE................................................ 12

1.1. Fogalmak operacionalizálása ........................................................ 12

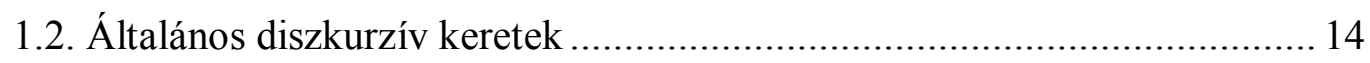

1.2.1. Békefenntartás vagy nemzetközi területi adminisztráció? ............ 17

1.2.2. Nemzetközi területi adminisztráció v. állam- és nemzetépités ...... 19

1.3. A nemzetközi igazgatás példái a 20. században: történeti áttekintés .......... 22

1.3.1. A Nemzetek Szövetsége idején müködö igazgatási modellek........ 22

1.3.2. Nemzetközi igazgatás a második világháborút követöen.............. 27

1.4. A nemzetközi területi igazgatás osztályozása ...................................... 61

1.4.1. A beavatkozás mértéke szerinti osztályozás ..............................6 61

1.4.2. Célok, funkciók szerinti osztályozás .........................................66

1.5. A nemzetközi területi igazgatással kapcsolatban felmerülö vitás kérdések,

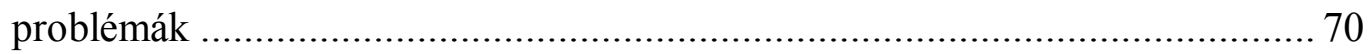

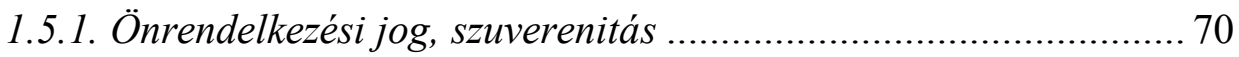

1.5.2. A szabályozó jogi környezet hiánya .......................................... 74

1.5.3. A nemzetközi területi adminisztráció legitimitása ....................... 75

1.5.4. A nemzetközi területi adminisztráció elszámoltathatósága .......... 79

2. NEMZETKÖZI TERÜLETI IGAZGATÁS BOSZNIA-HERCEGOVINÁBAN........................83

2.1. Bosznia-Hercegovina a daytoni megállapodás elfogadás után .................. 83

2.1.1. A nemzetközi igazgatás jogi alapja: daytoni megállapodás ......... 84

2.1.2. A boszniai állam felépitése és müködése 1995 után.................... 85

2.1.3. A boszniai állam müködési zavarai .......................................... 95

2.1.4. A fömegbizott intézménye ................................................... 99

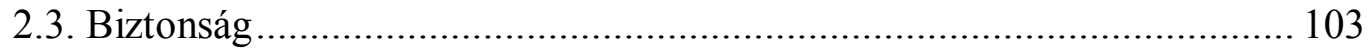

2.3.1. Nemzetközi katonai erök ................................................... 103

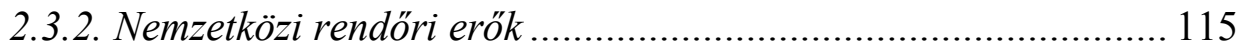

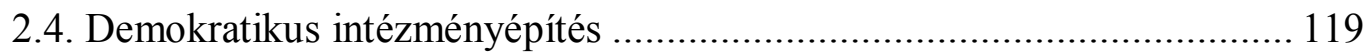


3. A NEMZETKöZI IGAZGATÁs KoSZOVÓBAN....................................................... 128

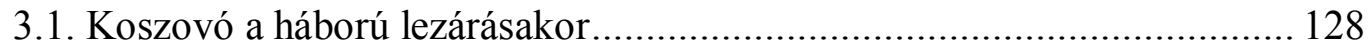

3.1.1. A nemzetközi igazgatás jogi alapja: az 1244-es számú BT

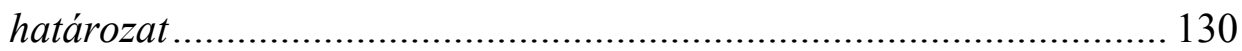

3.2. Nemzetközi igazgatás Koszovóban 1999 és 2008 között........................ 132

3.2.1. Az UNMIK eredeti pilléres szerkezete és az SRSG................... 134

3.2.2. Az UNMIK-vezette nemzetközi civil igazgatás szakaszai ........... 135

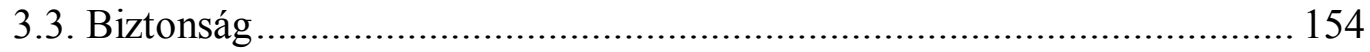

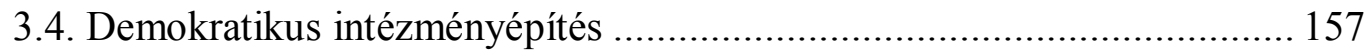

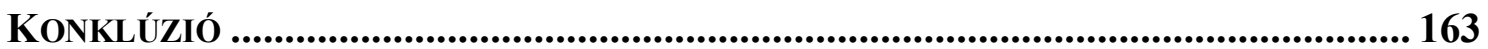

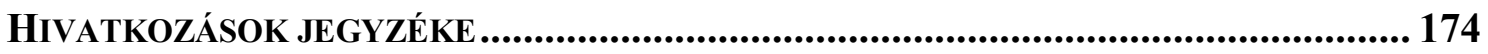

A SZERZŐ TÉMÁBAN MEGJELENT PUBLIKÁCIÓI ................................................... 191 


\section{BEVEZETÉS}

A nemzetközi területi adminisztrációk vizsgálatának aktualitása az utóbbi évtizedekben nem szorul különösebb indoklásra: Afganisztánban, Irakban, Kelet-Timorban, BoszniaHercegovinában, Koszovóban és számos afrikai országban müködtet a nemzetközi közösség napjainkban is katonai és civil aspektussal bíró igazgatási missziókat. Le kell szögeznünk azonban, hogy a nemzetközi igazgatás első példáinak alkalmazására már a huszadik század első évtizedeiben sor került, fejlődésében pedig fontos állomás volt először a Nemzetek Szövetsége, majd az Egyesült Nemzetek Szervezetének gyakorlata.

A nemzetközi területi igazgatás jelenkori példái azonban jelentős részben a poszthidegháborús nemzetközi rendszer által kitermelt (vagy inkább akkorra eszkalálódott) válságok szükséges következményei. A nemzetközi kapcsolatokkal foglalkozók körében mára már nem kérdőjelezik meg azt az alapvető tényt, hogy a hidegháború vége óta az államokon belüli és nem az államok közötti konfliktusok fenyegetik egyre inkább a nemzetközi békét és biztonságot. ${ }^{1}$ Az államokon belül pedig leggyakrabban az ott élő etnikumok közötti viszályok erősödnek fegyveres összecsapásokká, polgárháborúkká, s különösen nagy a veszély ennek bekövetkeztére a multietnikus társadalmakban. A hidegháború vége óta ilyen, etnikai jelleggel is bíró konfliktusok törtek ki a délszláv régióban, a posztszovjet térségben, Ázsiában és Afrikában is; az ezeken a területeken életre hívott nemzetközi adminisztrációs modellek müködtetésének fô oka, hogy a szóban forgó célállamok (vagy állam alatti entitások) nem képesek a fegyveres válságból kilábalva kormányzati funkcióikat gyakorolni. Ezt a szerepet vállalják fel ideiglenes jelleggel a nemzetközi területi adminisztráció civil komponensének intézményei, a nemzetközi katonai jelenlétre pedig legtöbbször azért van szükség, hogy a harcok kiújulását megakadályozza és így a térség biztonságát garantálja, valamint azért is, hogy a polgári adminisztráció stabil körülmények között müködhessen.

\footnotetext{
${ }^{1}$ Sollenberg és Wallensteen szerint 1995-ben a világban zajló mind a harminc súlyos fegyveres konfliktus államon belüli konfliktus volt. (Sollenberg-Wallensteen [1996] p. 15.) Ugyanerbben az évben a Heidelberg Egyetem kutatócsoportja 35 súlyos államon belüli konfliktust tartott számon, míg 2007-ben 32-t. (Conflict Barometer [2008] p. 2.)
} 
A nemzetközi igazgatás egyes modelljei a bevonódás mértékét és az átvett igazgatásikormányzati jogosítványok körét tekintve sokfélék, de minden esetben igaz, hogy alkalmazásukat a következő paradoxon kíséri: a nemzetközi igazgatás létezésének célja, hogy a válságból kilábaló entitás önkormányzó képességét helyreállítsa, saját sorsának irányítását fokozatosan a helyi lakosság kezébe adja (vagyis hagyja érvényesülni az önrendelkezési jogot), miközben a nemzetközi adminisztrációs struktúra - müködése nyomán - éppen az önrendelkezési jogukban korlátozza ezen területek lakosságát. A dolgozat a két esettanulmány (Bosznia és Koszovó) kiválasztásával a balkáni térségre fókuszál, ahol a jelenleg is müködő nemzetközi területi adminisztrációs modellek a két állam újjáépítésén és a gazdasági, társadalmi, jogi, intézményi és biztonsági konszolidáció megvalósításának céljából tevékenykednek.

A disszertáció egyik célja annak vizsgálata, hogy - a nemzetközi adminisztráció elméleti alapvetéseinek és eddigi gyakorlatának áttekintése után - megállapítsa a balkáni területi igazgatás példáiról (a boszniai és a koszovói modellről), hogy a többi esethez képest eltérő - esetleg addig nem tapasztalt - karakterisztikákkal bírnak-e?

A disszertáció másik célja az, hogy megvizsgálja: a nemzetközi területi adminisztráció balkáni példái hogyan értékelhetők a célokat és a megvalósítás hatékonyságát illetően a Balkán konszolidálása terén, s igazolható-e az a feltételezés, hogy megfigyelhető valamiféle határozott irányú - és az igazgatási modellek egyfajta „evolúcióját” bizonyító - pozitív irányú elmozdulás a válságok (boszniai és koszovói) kezelését illetően. Azaz: a kilencvenes évek elejétől jelen levő, és tevékenységükkel sok kritikai megjegyzést provokáló nemzetközi aktorok ${ }^{2}$ mit tanultak a térségben eltöltött csaknem két évtized alatt, törekedtek-e (törekednek-e) arra, hogy eddigi tapasztalataikból

\footnotetext{
${ }^{2}$ A nemzetközi területi adminisztrációk alanyain, vagyis a nemzetközi szereplőkön (aktorokon) a dolgozatban szuverén államokat, univerzális, partikuláris vagy regionális nemzetközi szervezeteket vagy nemzetközi NGO-kat értünk. Utóbbiakat - a nem kormányzati szervezeteket - nem tárgyalja részletesen a dolgozat, hiszen lehetetlen lenne pontosan számba venni a több ezer térségben tevékenykedő szervezetet, ezért az NGO-kat illetően csak általános jellegủ megállapításokat teszünk szerepükről. Az egyéb nemzetközi szervezetek közül a dolgozat vizsgálati fókusza elsősorban az Egyesült Nemzetek Szervezetére, a NATO-ra, az Európai Unióra, az Európai Biztonsági és Együttmüködési Szervezetre és az Európa Tanácsra irányul, $\mathrm{s}$ természetesen - a téma tárgyalásához szükséges mértékben - olyan sajátos formációkat is érintünk, mint az ún. Kontakt Csoportot vagy a G8-ak csoportját, valamint a nemzetközi pénzügyi szervezetek közül a legfontosabbakat. A dolgozat abból az alapvető feltételezésből indul ki, hogy a nemzetközi szervezetek és együttműködések tevékenységét alapvetően meghatározhatják és befolyásolhatják a tagállamok nemzeti érdekei, ezért a nemzetközi szereplők közé sorolom az egyes államokat is, s abban az esetben, ha valamely nemzetközi szervezet tevékenysége mögött tetten érhető a nemzeti érdek vagy sajátos külpolitikai törekvés, ezt jelzem is.
} 
kiindulva egy komplex és együttmüködésen alapuló stratégiát dolgozzanak ki arra, hogy a régiót a működőképes piacgazdasággal rendelkező demokratikus jogállamok sorába vezessék? A dolgozat egyik feltevése, hogy történt előrelépés ezen a területen, de amennyiben a nemzetközi közösség hatékonyabbá kívánja tenni ténykedését a térségben (és esetleg a világ más régióiban), akkor több ponton kell újragondolnia tevékenységét.

\section{A DISSZERTÁCIÓ MÓDSZERTANI ALAPJAI}

A dolgozat a nemzetközi adminisztrációk müködésére fókuszál Boszniában és Koszovóban, mindkét helyen a válságok fegyveres szakaszainak lezárulása után. A nemzetközi szervezetek / aktorok tevékenysége adott dimenziók mentén vizsgálható, ezek: a biztonsági, a demokratikus jogállamiság intézményrendszerét illetö, a humán és a gazdasági aspektusok. A négy dimenzió közül a dolgozatban az elsö kettő vizsgálatával foglalkozunk részletesen, a másik kettő későbbi kutatások irányát jelölheti ki.

A disszertáció a boszniai és koszovói eseményekre koncentrál, s a nemzetközi közösség e két válsággal kapcsolatos magatartását teszi elemzés tárgyává. Ezt a szükítést indokolja a téma behatárolásának szükségessége, valamint az alábbi tények:

1) ez a két válság tekinthető a legsúlyosabbnak a térségben - mind az emberi, mind az anyagi áldozatokat tekintve -, s itt került sor mindkét esetben a válság fegyveres konfliktussá eszkalálódására is;

2) a nemzetközi közösség az említett két válság során reagált a legdinamikusabban a térség eseményeire, $\mathrm{s}$ avatkozott be fegyveresen mindkét esetben;

3) a két válság időben és térben is eltér, ugyanakkor számos hasonlóságot fedezhetünk fel tulajdonságaikban: mindez jó alapot nyújthat a komparatív elemzéshez;

4) a nemzetközi közösség továbbra is jelen van a két vizsgált területen: mind a polgári, mind pedig a katonai igazgatás területén meghatározó szerepet játszik, ez a Balkán többi országában így nem jellemző. 
A dolgozatban nem térünk ki a válságok történeti előzményeinek vagy krónikájának ismertetésére, több remek magyar nyelvü monográfia és tanulmánykötet foglalkozik ezzel, s számos idegen nyelvű munka is rendelkezésünkre áll. ${ }^{3}$ Szintén nem kívánja a dolgozat bemutatni azt, hogy a vizsgálódás célállamai (Bosznia és Koszovó) egészen pontosan meddig jutottak el napjainkra a demokratizálódás útján, hogyan alakultak belső reformjaik stb. Csak azok a belső folyamatok, események kerülnek említésre, amelyek a nemzetközi szerepvállalás szempontjából alapvető jelentőségüek, vagy magyarázó körülményként szükséges azok ismerete.

Mindkét esettanulmányra jellemző, hogy a dolgozat a válságok fegyveres szakaszának lezárulása utáni időszakban vizsgálódik: Bosznia esetében napjainkig, Koszovóban pedig elsősorban a szakaszhatárként jellemezhető 2008-as évig, amikor Koszovó egyoldalúan kinyilvánította függetlenségét és ugyanebben az évben a nemzetközi területi adminisztráció is jelentős változásokon ment keresztül. A tematikus lehatárolások kereteit a választott dimenziók jelölik ki.

A dolgozat első, bevezető szakasza két funkciót kell, hogy ellásson: egyrészt az eddig megvalósult nemzetközi adminisztrációkkal kapcsolatos elméleti hátteret vázoljuk itt fel (a disszertáció által felvetett kérdések vizsgálatához szükséges mértékben), másrészt megismerkedünk az eddigi gyakorlati példákkal.

A dolgozat második és harmadik részében a két esettanulmány kap helyet, mindkettőnél bemutatjuk elsőként a válságot lezáró, ún. rendező dokumentumokat - Boszniánál az 1995-ös daytoni megállapodást, Koszovónál pedig az 1999-ben elfogadott 1244. sz. BT határozatot -, majd ahol szükséges, kitérünk a nemzetközi civil és biztonsági jelenlétet alapvetően meghatározó környezeti tényezők bemutatására, végül a választott dimenziók (a biztonsági és a demokratikus intézményépítést illető aspektusok) mentén vizsgáljuk és értékeljük a nemzetközi területi adminisztráció modelljeit. A boszniai és a

\footnotetext{
${ }^{3}$ A magyar és idegen nyelvű általános források - korántsem teljes - sorában az alábbi munkákat érdemes kiemelni: Juhász József [1999]: Volt egyszer egy Jugoszlávia. A délszláv állam története. Aula, Budapest; Juhász József et al. [2000]: Koszovó. Egy válság anatómiája. Osiris, Budapest; Jelavich, Barbara [1996]: A Balkán története I, II. Osiris, Budapest; Kaplan, Robert D. [1994]: Balkan Ghosts. A journey through history. Picador, New York; Malcolm, Noel [1996]: Bosnia. A Short History. Papermac, London; Judah, Tim [2008]: Kosovo: What Everyone Needs to Know. Oxford University Press, Oxford; Malcolm, Noel [2002]: Kosovo. A Short History. Pan Books, London; King, Ian - Mason, Whit [2006]: Peace at any price. How the world failed Kosovo. Hurst, London; Bieber, Florian et al. [2009]: Understanding the War in Kosovo. Routledge, London.
} 
koszovói rész struktúrája és felépítése több helyen azonban eltérő logikát követ, ennek az az oka, hogy az alapvető jellemzőiket illetően lényeges különbségek vannak a két választott entitás között. Boszniában a nemzetközi igazgatás egy szuverén, működőképes demokratikus intézményrendszerrel bíró államba települt, ahol a nemzetközi komponens az állam irányításában a helyi elem mellett jelenhetett meg; itt éppen ezért a boszniai intézményekre is nagyobb hangsúly kell, hogy helyeződjön. Koszovóban ezzel szemben egy nem szuverén és bizonytalan státuszú entitásban a nemzetközi területi adminisztráció civil komponense müködésének kezdeti szakaszában az igazgatási funkciókat közvetlenül gyakorolta, a helyi autonóm szervek minimális bevonásával. A koszovói részben éppen ezért inkább a közvetlen nemzetközi igazgatással foglalkozunk hosszabban, s azzal az átmeneti időszakkal, amikor a kompetenciák átadása a helyi szerveknek már megkezdődött, de a nemzetközi komponens még hangsúlyosan jelen van, a koszovói intézmények bemutatásának kevesebb teret szentelünk. A két vizsgált dimenzió természetesen mindkét esettanulmányban megjelenik (bár szintén nagyobb tér jut itt is a boszniai modellnek), s mind Boszna-Hercegovina, mind pedig Koszovó esetében be kívánjuk bemutatni, hogy az egyes politikaterületeken mely intézmények és miként vállaltak aktív szerepet a nemzetközi adminisztrációs modellek működtetésében. 


\section{A NEMZETKÖZI TERÜLETI IGAZGATÁS ELMÉLETE}

\subsection{Fogalmak operacionalizálása}

A ,területi adminisztráció” kifejezést a szakirodalom gyakran alkalmazza a nemzetközi igazgatási struktúrák megjelölésére, az viszont meglehetősen tág keretek között mozog, hogy az egyes szakértők mit értenek alatta: ez elsősorban attól függ, hogy az adminisztráció mely fajtáját sorolják ide. A tág értelmezésre mutat példát Wilde, aki a nemzetközi területi igazgatást az idegenben végrehajtott igazgatási misszió egy fajtájának tekinti. A fogalom Wilde szerint a következőképpen definiálható: „a »területi igazgatás« egy adott területi egység müködtetésére formálisan létrehozott és helyben müködtetett irányítási struktúra”, amely jellegét tekintve lehet korlátozott vagy átfogó, attól függően, hogy a nemzetközi struktúra csupán felügyeleti és ellenőrzési jogokat gyakorol-e a helyiek irányítása alatt álló igazgatás felett, vagy azt teljes egészében maga müködteti. (Wilde [2001] p. 585.)

Chesterman már egy szükebb értelmezést alkalmaz: következetesen az ,átmeneti igazgatás” kifejezést használja a nemzetközi adminisztrációra, s olyan műveletet ért alatta, amelyben a nemzetközi aktorok a választások lebonyolításában, az emberi jogok vagy a jogállamiság területén történő technikai segítségnyújtásban, a védelmi szektor reformjában vagy a fejlesztési segélyezés valamely formájában vesznek részt, miközben az állami jogosítványok egy részével vagy egészével ideiglenesen rendelkeznek. (Chesterman [2004] p. 5.)

A Handbook on United Nations Multidimensional Peacekeeping Operations címü kiadvány az ENSZ ideiglenes vagy átmeneti igazgatása alatt egy állam területén megvalósuló, s a törvényhozói, a végrehajtó és a bírói ágra is kiterjedő hatalmat ért. (DPKO [2003] p. 20.)

Stahn definíciója hasonlít az ENSZ imént ismertetett meghatározásához, amennyiben szerinte egy nemzetközi entitás által kivitelezett - végrehajtó, törvényhozó vagy bírói hatalomgyakorlásról van szó a nemzetközi területi igazgatás esetében, méghozzá egy 
olyan területen, amelyet valamely közösségi érdek mentén ideiglenesen nemzetközi felügyelet vagy támogatás alá helyeztek. (Stahn [2008] pp. 44-45.)

Utolsóként mutatjuk be Zaum definícióját, amely azon túl, hogy az egyik legteljesebb fogalommeghatározást adja, egyben átvezet bennünket a következő tárgyalt témára is: hogyan lehet elkülöníteni a konfliktus sújtotta régiókban jellemző más jellegü nemzetközi szerepvállalástól a nemzetközi területi adminisztrációt?

Zaum szerint a nemzetközi igazgatás a következőképpen definiálható: nemzetközi szereplők kormányzati funkciókat gyakorolnak egy meghatározott földrajzi terület felett, s az utóbbi időben létrejött nemzetközi igazgatási példákban a nemzetközi szereplők bekapcsolódnak az adott terület politikai és társadalmi intézményeinek létrehozásába vagy megreformálásába. A meghatározás három olyan elemet tartalmaz, amely egyben alkalmas arra is, hogy megkülönböztesse a nemzetközi igazgatást a nemzetközi szerepvállalás más formáitól (kolonialista protektorátus, gyámsági rendszer, fejlesztési szervezetek), ezek az elemek:

- nem egyetlen ország hozza létre és müködteti, hanem egy nemzetközi szervezet (Népszövetség, ENSZ, EBESZ, EU) vagy egy olyan nemzetközi grémium, amely széleskörü nemzetközi összefogással jött létre, s amely elszámolási kötelezettséggel tartozik a létrehozó nemzetközi szereplők felé;

- a nemzetközi szerepvállalás kiterjed a kormányzásra, s nem csupán támogató és / vagy ellenőrző funkciója van (ez különbözteti meg pl. a választási megfigyeléstől);

- az adminisztráció „,nemzetközi” térbeli identitása eltér a terület és az ott élő lakosság „helyi” identitásától (ez mutatja a különbséget pl. az EU-hoz képest, ahol ugyanazt a térbeli identitást vallják magukénak a részes államok és azok lakosai);

- egy negyedik jellemző tulajdonság, hogy a kormányzati funkciók meghatározott körét vállalja magára a nemzetközi adminisztráció, ez szorítkozhat néhány dologra (például a biztonság- és fiskális politikára, mint az UNTAC esetében Kambodzsában) de lehet átfogó - akár mindent felölelő - jellegü is (ilyen Koszovó és az UNMIK esete, vagy az UNTAES Kelet-Timorban) (Zaum [2007] pp. 51-52.) 
A poszthidegháborús időszakban a nemzetközi igazgatás jelentősége megnőtt, s ez a kijelentés nem csupán az ilyen jellegü missziók számának emelkedésére utal, hanem arra a tényre is, hogy a nemzetközi irányítás alatt álló adminisztrációkat jellemzően az addig megszokotthoz képest szélesebb hatáskörrel ruházták fel az alapító nemzetközi szereplők. ${ }^{4}$ Egy adott országban zajló fegyveres konfliktus esetében a nemzetközi közösség - fegyveres erőszakkal járó vagy anélküli - beavatkozásához és a fegyverszünetet követően a célországban való további tartózkodásához több fogalom is kapcsolódik, ilyenek a békefenntartás, békeépítés, nemzetépítés, államépítés. Az imént felsorolt fogalmak egyben kijelölik azokat a kereteket is, amelyeken belül sokan értelmezik a nemzetközi területi igazgatást - az ilyen módon történő címkézés azonban nemcsak hogy félrevezető, de egyéb problémákat is felvet. A továbbiakban elsőként ismertetjük azokat a leggyakoribb narratívákat, amelyeken belül (vagy inkább azokkal szorosan egybefonódva) a nemzetközi igazgatás eseteit legtöbbször értelmezik. Ezt követően pedig - a szükséges lehatárolások nyomán - a nemzetközi rendszer említett jelenségeit és a nemzetközi igazgatást igyekszünk egymástól megkülönböztetni. ${ }^{5}$

\section{2. Általános diszkurzív keretek}

Wilde szerint a nemzetközi igazgatás tárgyalása a szakirodalomban leggyakrabban négy diszkurzív keretbe helyezve történik, ezek pedig: a ,progresszív történeti”, a „célorientáltan leegyszerüsítő”, a „,bukott állam” és a „technokrata” narratíva. (Wilde [2004])

A ,progresszív történeti” megközelítést valló iskola képviselőinek meggyőződése, hogy a területi igazgatás egyes modelljei - $\mathrm{s}$ itt leggyakrabban a koszovói és a kelet-timori példákra szokás utalni - a történelemben forradalmian újak, addig meg nem tapasztalt jellegzetességgel bírók és egyfajta evolúciós folyamat csúcspontjának tekintendők. ${ }^{6}$

\footnotetext{
${ }^{4}$ Mindez persze nem jelenti azt, hogy a nemzetközi igazgatási modellek korábbi példáinál ne fordult volna elő, hogy a nemzetközi szereplők meglehetősen komplex feladatokat láttak el; a történelmi példák ismertetésénél erről még lesz szó az 1.3. alfejezetben.

${ }^{5}$ Nem mindig lehetséges és szükséges ugyanis a szétválasztás, hiszen a nemzetépítés és/vagy államépítés fogalma például szorosan összefonódhat a nemzetközi adminisztrációval: az államépítés a müködő kormányzás megteremtését vagy visszaállítását szolgálja, s gyakran a nemzetközi igazgatás egyik fontos részterületeként értelmezendő (ld. UNMIK). Más esetben a nemzetközi igazgatásnak nem célja autonóm kormányzati struktúrák létrehozása, csak valamiféle felügyeletet gyakorol a már müködő kormányzat felett egy bizonyos ideig (ld. UNTAES).

${ }^{6}$ Strohmeyer szintén a koszovói UNMIK-ot és a kelet-timori UNTAET-et tekinti a nemzetközi igazgatás
} 
Ehhez a történeti narratívához tehát szorosan kapcsolódik a kivételesség mítosza, amely az ún. generációs megközelítésben szintén megjelenik, s leginkább a nemzetközi igazgatásnak a békefenntartással összefüggésben vagy annak keretein belül történő tárgyalásánál fordul elő. A történeti szemléletre utaló fogalmak itt a „régi” és az „új”, a „klasszikus” és „új típusú”, de a békefenntartás poszthidegháborús mainstream megközelítésében is tetten érhető, amennyiben az intézmény 20. századi történetét generációkra szokás tagolni. Az egyes generációk időbeli szakaszhatárai ugyan kisebb eltéréseket mutathatnak a különböző szerzők olvasatában, de a számunkra releváns nemzetközi területi igazgatási modelleket legtöbben a békefenntartás harmadik vagy negyedik generációjaként értelmezik. (Gray [2008] p. 159., Kondoch [2001] p. 246.)

Wilde szerint ez a megközelítés azért nem helyes, mert a nemzetközi igazgatási modellek huszadi századi példáinak vizsgálata során bebizonyítható, hogy komplex missziók nem csupán az elmúlt két évtizedben müködtek (müködnek), hanem már korábban is. Szerinte túlzottan leegyszerüsítő az a megközelítés, amelynek lineáris fejlődési logikája szerint az újabb igazgatási modellek egyre összetettebb feladatkör ellátását vállalják magukra. Wilde szerint igaz ugyan, hogy a poszthidegháborús időszakban sokszorosára növekedett az ENSZ-missziók száma a világban, s ezek közt több a komplex feladatkörrel bíró is, de a hidegháború vége nem minőségi, hanem sokkal inkább mennyiségi cezúrát jelentett. (Wilde [2004] p. 79.) Ezt az álláspontot erősíti Ratner, aki ugyan használja a generációs korszakolást, de a békefenntartásról írott könyvében több esetben utal arra, hogy egyes első generációs nemzetközi igazgatási missziók az új paradigma szellemiségének megfelelően (értsd: a második generációra jellemző karakterisztikákkal) müködtek, mintegy megelőzve saját korukat. (Ratner [1997] p. 91.) Wilde amellett érvel, hogy - a történeti evolutív megközelítés hibáit elkerülendő - inkább az olyan fogalmak használata lenne ajánlott, mint: „alapvető” vs. „komplex funkciókat ellátó” vagy „multifunkcionális” nemzetközi missziók. (Wilde [2004] p. 80.)

egyfajta „csúcsmodelljének”, amennyiben az ENSZ egy egész entitásra kiterjedő igazgatási és jogrendszert hozott létre „gyakorlatilag a semmiböl” olyan módon, ahogyan azt korábban egyik missziójában sem volt jellemző. (Strohmayer [2001] p. 46.) Hasonló szellemben nyilatkozik Chopra az UNTAET-röl, amely szerinte az ENSZ ,a történelemben első alkalommal” tölti be a szuverén föhatalom szerepét egy születő nemzetállam esetében. (Chopra [2000] p. 27.) 
A jelen alfejezet elején említett irányzatok közül a másodikat „célorientáltan leegyszerüsítőnek" nevezhetjük. Ennek a narratívának a lényege, hogy a területi igazgatási modelleket - az esszencialista logikát követve - annak alapján címkézi, hogy mi a legfontosabb elérendő céljuk. Ez a megközelítés leginkább akkor érhető tetten, amikor a vizsgált nemzetközi adminisztráció létrehozását a ,konfliktust követő helyreállítással” helyezik szoros összefüggésbe. A konfliktust követő helyreállítást legfőbb célként megjelölő tárgyalásmóddal Wilde szerint több probléma is akad. Elsőként a megnevezés azt sugallja, hogy egyrészt a nemzetközi területi igazgatás a konfliktus - s általában a szükebben vett fegyveres konfliktust szokás ez alatt érteni lezárását követően áll fel, másrészt, hogy célja a konfliktus negatív következményeinek felszámolása. Azonban mindkét kijelentés túlzottan általánosító, mert ugyan igaz, hogy a területi igazgatási modellek többsége fegyveres konfliktust követően települ, ez azonban nem érvényes minden egyes esetre, például Nyugat-Új-Guinea esetében az ENSZ-igazgatás célja mindenekelőtt a terület átadásának levezénylése volt (Hollandia fennhatósága alól Indonézia szuverenitása alá). (Wilde [2004] p. 82.)

Szintén legyszerüsítő az, amikor a nemzetközi adminisztráció céljaként a konfliktus következményeinek felszámolását jelölik meg, hiszen például Bosznia esetében emellett szintén fontos volt az igazgatás polgári aspektusának megteremtésekor az a cél, hogy hozzájáruljanak egy, a nyugati sztenderdeknek megfelelő polgári demokratikus jogállam és müködő piacgazdaság megteremtéséhez, s egyúttal támogassák az új államot a háború miatt megkésett rendszerváltozás véghezvitelében. Koszovó esetében pedig az UNMIK felállítására azért volt szükség, mert a válságot lezáró 1244-es számú BT határozat a területet kivonta Szerbia fennhatósága alól, a korábban a szerbek által müködtetett államigazgatás a szerbek távozásával gyakorlatilag ellehetetlenült, s ezt az ürt töltötték ki a nemzetközi civil igazgatási struktúra telepítésével. Nem a koszovói háború közvetlen következménye volt tehát az igazgatási vákuum keletkezése, hanem az a rendezés részeként, a nemzetközi közösség döntése következtében alakult ki. Szintén ennek a megközelítésnek a hibája, hogy alkalmazása nyomán a fókuszba helyzett cél (pl. konfliktus következményeinek felszámolása) elhalványítja a komplex igazgatási struktúra által felvállalt egyéb célokat, $\mathrm{s}$ hangsúlyosan legitimálja az elsődlegesen kiemelt feladatot mindamellett, hogy eltereli a figyelmet az esetleges negatív hatásokról. (Wilde [2004] p. 89.) 
Meglehetősen sok kritika éri a diszkurzív keretrendszer harmadikként említett megközelítését, az ún. „bukott állam” paradigmát. A számunkra releváns bírálatok közül érdemes itt is kiemelni - az előző bekezdésben már kifejtett - címkézés azon következményét, hogy az túlzott kizárólagosságot biztosít az adott entitás bukott mivoltának (vagyis annak, hogy képtelen kormányozni önmagát), s ezzel más, szintén releváns problémákról eltereli a figyelmet.

A másik említésre méltó jelenség a felelősség ún. aszimmetrikus koncepciója, (Wilde [2004] p. 90.) amelynek lényege, hogy az állam helyzetét általában egyoldalúan a belső tényezők és szereplők felelősségévé teszi a „bukott állam” megközelítés, s nem foglalkozik az esetleges külső befolyásoló motívumokkal és aktorokkal (például a volt gyarmattartók hibáinak terhes örökségével, a nemzetközi pénzügyi szervezetek vagy multinacionális piaci szereplők müködésének negatív hatásaival stb.). Persze tegyük hozzá mindjárt, hogy a nemzetközi színtéren nem is áll olyan eszközrendszer a rendelkezésre ehhez, mint például a nemzetközi igazgatási struktúrák révén az egyes kormányzati deficittel küzdő államok esetében.

A negyedikként említhető ,techokrata” diszkurzív stratégia Wilde szerint a nemzetközi igazgatást nagyrészt vagy teljes egészében technokrata szemszögből közelíti, s a gyakorlati megfontolásokra fókuszál, például foglalkozik az alkalmazandó jog kérdéskörével, de nem boncolgatja a nemzetközi igazgatási elszámoltathatóságának ügyét. A megközelítés következménye tehát, hogy elfed vagy negligál számos egyéb alapvetően politikai jellegü aspektust, s az adminisztrációs modell értékelésekor így jelentősen lecsökkenti a lehetséges értékelési szempontok körét. (Wilde [2004] p. 96.)

Az általános diszkurzív keretek ismertetése után különítsük el egymástól a nemzetközi területi igazgatást és a kapcsolódó fogalmakat.

\subsubsection{Békefenntartás vagy nemzetközi területi adminisztráció?}

A szélesebb értelemben definiált, multidimenzionális békefenntartás ${ }^{7}$ egyes kategóriáit - elsősorban a békeépítésre gondolunk - viszonylag könnyü elkülöníteni a nemzetközi

\footnotetext{
${ }^{7}$ A békefenntartás definíciójára hosszú ideig kellett várni, hiszen maga a kifejezés nem szerepel pl. az
} 
adminisztrációtól. ${ }^{8}$ A békeépítés tevékenységi köre a posztkonfliktusos időszakban elsősorban a leszerelésre, a fegyveres alakulatok demobilizálására, a rendőri állomány képzésére, esetenként a demokratikus választások lebonyolításában való részvételre és a menekültek visszatérésének előmozdítására terjed ki.

Ezzel szemben a nemzetközi igazgatás két vonatkozásban is túlmutat a békefenntartáson. Az egyik, hogy mind a végrehajtó, mind a jogalkotó, mind pedig a bírói hatalmi ágakban sokkal szélesebb körben és jóval intenzívebben bevonódik az állam stabil müködésének helyreállítási folyamatába: döntéshozói és jogalkotói potenciálja kiterjedhet így az állami gazdaságpolitika alapvető aspektusaira és intézményeire, ${ }^{9}$ a médiára, az oktatási rendszerre stb. A másik jellemző különbség, hogy a nemzetközi adminisztráció sokkal inkább ,politikai” jellegü, mint a békefenntartás, mely utóbbinál alapvető törekvés a politikai színezetű vagy a pártatlanságot bármely módon megkérdőjelező döntésektől való tartózkodás. A nemzetközi igazgatás múködéséböl fakadóan - nem kerülheti el az ilyen helyzeteket, s ez nyilvánvalóan nem is célja. (Caplan [2005] pp. 2-5.)

A békefenntartás és a nemzetközi igazgatás között ugyanakkor több hasonlóságot is felfedezhetünk: elsőként a tevékenységükben mutatkozó átfedéseket említhetjük (pl. az erőszakszervezetek „pacifikálása”, demokratikus újjászervezése, vagy a menekültek visszatérésének elősegítése); másodszor azt a tényt, hogy mindkét tevékenység legitim alapját jelenti az ENSZ-felhatalmazás; harmadszor pedig utalhatunk arra, hogy a nemzetközi közösség mindkettőben számos szereplője által képviselteti magát, ezek lehetnek államok vagy egyéb nemzetközi szervezetek (pl. a békefenntartás esetében a NATO, vagy az UNMIK esetében az EBESZ).

ENSZ Alapokmányában sem, s inkább ad hoc alapon, a gyakorlat termelte ki. (Lehoczki [2004] p. 1.)

${ }^{8}$ A szélesebb értelemben definiált békefenntartás esetében a Boutros Boutros-Ghali akkori ENSZ főtitkár által 1992-ben készített Békeprogram (An Agenda for Peace) kategóriáira utalunk, amelyek a békefenntartásnak egy konfliktus különböző szakaszaiban szükséges prioritásaira utal a megalkotott fogalmakkal: preventív diplomácia, béketeremtés, békefenntartás (szüken értelmezett), békekikényszerítés, békeépítés. (An Agenda for Peace [1992])

${ }^{9}$ Gondolhatunk itt a vámpolitikára, a monetáris és fiskális politikára, a közművekre, a vállalkozói környezet vagy a tulajdonjogok szabályozására, az adórendszerre stb. 


\subsubsection{Nemzetközi területi adminisztráció v. állam- és nemzetépítés}

A szakirodalom a nemzetközi igazgatás kapcsán is gyakran használja az állam- és nemzetépítés fogalmait, ám pontos jelentésükkel a legtöbb munka adós marad. Jelen dolgozatnak nem célja az állam- és nemzetépítés igen kiterjedt szakirodalmát bemutatni, s nem célunk a nemzet- és nacionalizmuselméletek alapvetően modernista vagy esszencialista irányzatainak és alirányzatainak bemutatása sem. Ehelyütt megelégszünk néhány szakértő álláspontjának ismertetetésével.

Wolfrum szerint az államépítés az állami struktúra fizikai infrastruktúrájának kiépítését, tulajdonképpen az államigazgatás megszervezését jelenti. (Wolfrum [2005] p. 653.) Ezzel szemben - vagy inkább ezen túlmenően - a nemzetépítés arra a folyamatra utal, amelynek során egy adott területen élő emberek egy állam lakosságává válnak, s már nemzetként kell rájuk tekintenünk. A nemzet nem kizárólag a lakosság tagjai között meglévő etnikai rokonságon alapul - bár a nemzetépítést gyakran kíséri az etnikai homogenizáció politikai instrumentalizációja -, hanem legalább annyira fontos a közös értékekben való hit, a közös múlt, valamint az közös kulturális jellemzők (föként a nyelv és a vallás) és a szolidaritás. Az állam- és nemzetépítés a válság sújtotta régiókban természetesen szorosan összefügg egymással, általában elöbbi járul hozzá az utóbbihoz, de csak abban az esetben, ha összeegyeztethetőek. A nemzetközi adminisztráció kapcsán gyakran merül fel az a kritika, hogy a helyi hagyományokhoz és kultúrához nem kötődő, az adott területen gyökértelen nyugati minták oktrojálása az államépítés során nem képes érdemben előmozdítani a megbékéléshez szükséges nemzetépítése folyamatot, sőt inkább akadályozza azt. (Wolfrum [2005] p. 654.)

Stahn osztja Wolfrum érvelését annyiban, hogy az államépítés és a nemzetépítés időnként szorosan összekapcsolódik egymással. Államépítés alatt a válság sújtotta társadalmak újjáépítését érti elsősorban a szükséges intézmények létrehozása révén, a nemzetépítés viszont szerinte komplexebb folyamat, amennyiben nem elégszik meg az intézményi környezet létrehozásával, hanem ezen túl célul tűzi ki a nemzeti összetartozás érzésének felélesztését és ennek alapján új identitás megteremtését. (Stahn [2008] pp. 404-405.) 
Vannak szerzők, akik a nemzetközi területi adminisztrációt nem különböztetik meg élesen az államépítéstől, inkább a kettő közti kapcsolatot hangsúlyozzák: Caplan szerint a nemzetközi igazgatás olyan művelet, amelynek a célja, hogy egy új állam létrejöttét segítse, vagy legalább mozdítsa elő a lényegi autonómia megvalósulását. Szerinte a nemzetközi adminisztrációnak gyakran integráns része az államépítés, $\mathrm{s}$ azon erőfeszítéseket jelenti, amelyek célja, hogy hatékony és autonóm kormányzati struktúrát hozzanak létre vagy állítsanak helyre egy államban vagy egy területen, ahol az addig nem létezett, vagy ha igen, akkor súlyosan erodálódott. A nemzetközi adminisztrációnak nem feltétlenül feladata az autonóm kormányzat létrehozása, KeletSzlavóniában például éppen az volt a cél, hogy a terület felett, ahol az autonóm kormányzati jogköröket a háború végére a horvátországi szerbek gyakorolták - miután a délszláv válság idején szakadár formációként kiszakították Horvátországból a keletszlavóniai részt is -, visszaállítsák a horvát állam szuverenitását. (Caplan [2005] p. 3.)

Tansey abban látja a nemzetközi adminisztráció lényegét, hogy annak feladata nem az államépítés, hanem a rezsim-építés, vagyis direkt módon járul hozzá egy teljesen új politika rendszer létrehozásához; így pl. Boszniában és Koszovóban azt a folyamatot felügyeli és irányítja, ahogyan a korábbi nem-demokratikus struktúrák helyén demokratikus politikai szabályozóerők és intézmények jönnek létre. Míg az államépítés - ahogy a neve is jelzi - államot épít, addig a nemzetközi adminisztráció egy meghatározott rezsim létrehozására törekszik. A rezsim definíciója pedig a következő: szabályok, eljárások és normák összessége, amelyek meghatározzák, hogy az elit milyen úton juthat hatalomhoz, s ha azt megszerezte, milyen módon kell vele élnie. A demokratikus rezsimépítés így szükebb fogalom, mint az államépítés, mert ennek során a nemzetközi igazgatás csak az adott politikai rendszer létrehozására tett erőfeszítéseire fókuszál, de az állami müködést biztosító egyéb intézményekkel és folyamatokkal nem foglalkozik. (Tansey [2009] pp. 5-6.)

A legvilágosabban talán Chesterman világítja meg a nemzetközi adminisztráció és az államépítés viszonyát. Szerinte az államépítés kifejezés a „,kiterjedt - elsősorban, de nem kizárólag az ENSZ által kivitelezett - nemzetközi beavatkozásra utal, amely túlmutat a hagyományos békefenntartás és békeépítés mandátumán és olyan kormányzati struktúrák kiépítésére vagy újraépítésére irányul, amelyek képesek biztosítani az állampolgárok fizikai és gazdasági biztonságát.” (Chesterman [2004] 
p. 5.) Ez az államépítő tevékenység sokféle politikai, biztonsági, gazdasági ún. kvázikormányzati funkciót is magába foglalhat (pl. a védelmi szektor megreformálásában és a választások lebonyolításában nyújtott segítség). Az ,átmeneti adminisztráció” annyiban tér el az államépítéstől, hogy bár céljai ugyanazok - önálló működésre képes demokratikus kormányzati rendszer létrehozása -, de azokat úgy éri el, hogy az államhatalmi jogosítványok egy részét vagy egészét magához ragadja egy meghatározott időre.

A fogalmak operacionalizálása és lehatárolása után bemutatjuk a nemzetközi területi igazgatás történeti példáit. A példák egymásutánisága a kronológiai logikát követi, $\mathrm{s}$ ehelyütt jelezzük, hogy a bemutatott nemzetközi adminisztrációs struktúrák köre szükíthető vagy bővíthető lenne annak fényében, hogy mit is tekintünk nemzetközi területi adminisztrációnak; tekintve, hogy Zaum definíciója és Chesterman lehatárolása tünik a leghasznosabbnak témánk körüljárása során, ezért a példákat is ennek alapján választottuk ki. A másik ide kívánkozó megjegyzés: olyan eseteket mutatunk be az alábbiakban, ahol a létrehozás óta eltelt idő lehetővé teszi a leíráson túl a példák elemzését is, ezért a bemutatásban a legújabban létrehozott modellek közül jónéhány nem szerepel.

Talán kissé szokatlan módon az igazgatási példák bemutatását követően térünk rá a nemzetközi adminisztráció osztályozására, erre azért van szükség, mert egyrészt a példák ismerete szükséges ahhoz, hogy a csoportosítások mögött húzódó logika érthető legyen, másrészt ezáltal is igyekszünk elkerülni a dolgozatban az ismétlődéseket. 


\subsection{A nemzetközi igazgatás példái a 20. században: történeti áttekintés}

\subsubsection{A Nemzetek Szövetsége idején müködö igazgatási modellek}

A nemzetközi igazgatás gyakorlatának csíráit érdemes egészen a Nemzetek Szövetségéig visszavezetni. ${ }^{10}$ Első pillantásra talán kevésbé tủnik relevánsnak a történelmi példák és előzmények sorát ilyen messziről indítani, mégis azt állítjuk, hogy a népszövetségi nemzetközi rendszer tartogat mondanivalót a mai nemzetközi területi adminisztrációk vonatkozásában is.

Az első világháborút követően a versailles-i békében megtörtént a háború lezárása, Európa határainak újrarajzolása és a vesztesek korábbi gyarmatainak elosztása. Ezzel párhuzamosan jött létre egy új - valójában az első - univerzalizmusra törekvő nemzetközi szervezet, a Nemzetek Szövetsége (Népszövetség), amely többek között a wilsoni 14 pontban is vázolt önrendelkezési jog érvényre juttatását is vállalta. A vesztes államok (elsősorban Németország és az Oszmán Birodalom) birtokában levő európai területek ,igazgatására” a Népszövetség égisze alatt létrejött a mandátumrendszer. Itt fontos megjegyezni, hogy a mandátumrendszer nem elsősorban a wilsoni szellemiség mentén kibontakozó altruista kollektív cselekvés megnyilvánulásaként jött létre végül, hanem sokkal inkább a győztes hatalmak érdekei szerint formálódott. Ez abból is kitünik, hogy a vesztesek Európán kívüli gyarmatainak újraosztása és müködtetése ügyében a győztes hatalmak - érdekközösséggé formálódva - végül kevés beleszólást engedtek a Népszövetségnek, itt a multilateralizmus ugyanis már érdekeik ellen való volt. A Nemzetek Szövetsége inkább az európai vitás ügyekben juthatott nagyobb szerephez, itt ugyanis már jóval megosztottabbak voltak a győztesek a megoldásokat illetően. (Lásd a jelen fejezetben később.)

A mandátumterületeket három kategóriába sorolták aszerint, hogy az adott entitás mennyire képes kormányozni magát, illetve mennyire szorul a fejlett hatalmak

\footnotetext{
${ }^{10}$ Egyes szakértők a 20. század első évtizedéig, az 1903-ban makedón területen létrehozott, s 1908-ig müködő - az Osztrák-Magyar Monarchia és Oroszország kezdeményezésére felállított - nemzetközi igazgatási modellig vezetik vissza a példák sorát. Ebben az időszakban igyekeztek az európai hatalmak a délszláv keresztények és a muszlimok együttéléséből fakadó feszültségeket minimalizálni és stabilizálni a térséget. (Halász [2005/a] 248-249. o.)
} 
támogatására. ${ }^{11}$ Az első csoportba („A” kategória) az Oszmán Birodalom közel-keleti területei ${ }^{12}$ kerültek brit és francia mandátumterületként. Ezeket az entitásokat tekintették a függetlenedésre leginkább érettnek, a mandatárius állam feladata pedig abban állt, hogy segítse a mandátumterületet a kormányzásban addig, amíg az erre magától nem lesz képes szuverén államként. A második csoportba („,B” mandátumterület) az afrikai német gyarmatokat sorolták, a mandatáriusok itt is a britek és a franciák voltak, kiegészülve Belgiummal. ${ }^{13}$ Az ebben a kategóriában található, önállóságra kevésbé érett területek esetében a mandatárius gyakorolta ugyan a kormányzati funkciókat, de bizonyos megkötésekkel. A harmadik, ún. „C” kategóriájú - önkormányzásra leginkább

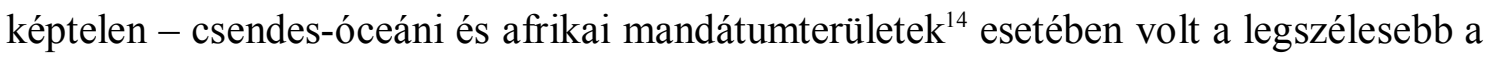
mandatárius jogosítványainak köre: ezeket a területeket sajátjaként (államterülete szerves részeként) igazgathatta. (Matz [2005] pp. 72-73.)

Karakteresebb és sikeresebb a Népszövetség szerepvállalása az európai ügyekben; a szervezet három esetben vállalta magára több-kevesebb mértékben az igazgatási funkciók gyakorlását: a Saar-vidéken, Gdańskban és Felső-Sziléziában.

\subsubsection{Saar-vidék}

A Saar-vidék sorsa az első világháború utáni Párizs környéki békerendezés következtében úgy alakult, hogy a terület a vesztes Németországtól népszövetségi irányítás alá került 1920-ban. Az ásványkincsekben (föként szénben) gazdag Saar-vidék német terület volt, de a háborúban győztes Franciaország igényt formált rá

\footnotetext{
${ }^{11}$ A „támogató hatalmak” részben a világháború gy”zztes hatalmai közül kerültek ki (Nagy-Britannia, Franciaország és Belgium), hozzájuk csatlakozott az afrikai kontinensen Dél-Afrika, a csendes-óceáni térségben pedig Ausztrália, Új-Zéland és Japán.

${ }^{12}$ „A” besorolású brit mandátumterület lett Irak és Palesztina (Transzjordániával együtt), a franciák kapták meg Libanont és Szíriát. A területek mindegyike elnyerte függetlenségét 1949-re.

13 „B” mandátumterületként Nagy-Britanniáé lett Tanganyika, közös brit-francia mandátum lett Togó és Kamerun, Belgiumnak pedig Ruanda-Urundi jutott. Mindegyik terület átkerült a második világháború után az ENSZ gyámsági rendszerébe, függetlenségüket csak a dekolonizációs folyamat során érték el.

${ }^{14}$ „C" mandátumterület lett német (később Nyugat-) Szamoa Új-Zéland irányítása alatt; Ausztrália ÚjGuineát és Naurut kapta (utóbbit a Brit Birodalom nevében kormányozta); Japán több kisebb csendesóceáni szigetet kapott a korábbi, egyenlítőtől északra fekvő német kézben levő szigetekből; Dél-Afrika pedig Délnyugat-Afrika (a későbbi Namíbia) felett gyakorolhatta a mandatárius jogokat. Az ENSZ megalakulása után a területek mindegyike átkerült a gyámsági rendszerbe, kivéve Délnyugat-Afrikát, mivel Dél-Afrika nem fogadta el a terület átminősítését és az ezzel járó kötelezettségeket, s továbbra is mandátumterületeként kívánta müködtetni Délnyugat-Afrikát. Az üggyel a Nemzetközi Bíróság több alkalommal is foglalkozott - 1950-es tanácsadó véleményében és az 1960-ban Libéria és Etiópia által a Dél-afrikai Köztársaság ellen indított ügyekben -, s évtizedekig napirenden volt az ENSZ-ben, végső rendezésére azonban csak 1990-ben került sor Namíbia függetlenné válásával.
} 
mindenekelőtt saját gazdasági érdekeit szem előtt tartva. A Nemzetek Szövetsége magához vonta a terület irányítását 15 éves átmeneti időszakra, ezt követően népszavazást kellett tartani a státuszt illetően. ${ }^{15}$ A Népszövetséget nem kötötte a népszavazás eredménye - ahogy akkoriban fogalmaztak, csak tetszés szerint figyelembe vehették vagy figyelmen kívül hagyhatták azt -, a lakosság azonban túlnyomó többségben a Németországgal való újraegyesülés mellett döntött, a Népszövetség pedig elfogadta ezt. (Chesterman [2004] pp. 18-19.) A területi igazgatás példái közül a Saarvidék esetében a szuverenitás azonban nem szállt át teljes egészében a Nemzetek Szövetségére, a terület de iure német fennhatóság alatt állt, a kormányzati jogokat viszont a szóban forgó időszakban a nemzetközi szervezet gyakorolta. (Wilde [2008] pp. 112-114.) Chesterman hívja fel arra a figyelmet, hogy a szuverenitás itt sajátos módon „háromfelé oszlott”, amennyiben formálisan Németországé maradt, anyagi érdekektől vezérelve Franciaország formált jogot rá, a valódi kormányzó hatalmat illetően pedig a Népszövetséghez került. A szuverenitás tradicionális szemlélete sérült így oly módon, hogy az állami szintről a szuverenitás egyrészt „felfelé mozdult”, s egy kormányközi nemzetközi szervezethez került, másrészt „lefelé” is, hiszen végső soron a nép döntött a terület sorsáról. (Chesterman [2004] p. 19.)

\subsubsection{Gdańsk}

Gdańsk 1920 és 1939 között állt részben népszövetségi irányítás alatt. Wilson az 1918 januárjában megfogalmazott 14 pontjában ${ }^{16}$ a független lengyel államért szállt síkra, amelynek a politikus véleménye szerint szabad és biztonságos tengeri kijáratot kellett biztosítani. Ennek a kívánalomnak a megvalósulása volt lényegében az a döntés, amely Gdańskot - a háború utáni rendezés részeként - a Nemzetek Szövetsége védelme alatt álló szabad városnak nyilvánította. ${ }^{17}$ (Wilde [2008] p. 114.) Fontos szempont volt a rendezésnél, hogy a Németországtól elszakított és többségében németek által lakott

\footnotetext{
${ }^{15}$ A népszavazáson a következőről döntöttek a terület lakosai: Franciaországhoz szeretnének tartozni, 2) Németországhoz szeretnének ismét csatlakozni, 3) továbbra is az első világháború utáni népszövetségi irányítás alatt kívánnak maradni.

16 "An independent Polish state should be erected which should include the territories inhabited by indisputably Polish populations, which should be assured a free and secure access to the sea, and whose political and economic independence and territorial integrity should be guaranteed by international covenant." (Point XIII.) (President Woodrow Wilson's Fourteen Points [é. n.])

${ }^{17}$ Formálisan itt sem gyakorolt kizárólagos jogokat a Népszövetség, hanem más nemzetközi aktorokkal együttesen irányította a területet. A versailles-i döntés értelmében Németország lemondott mindennemü jogáról és címéről a Szövetséges és Társult Hatalmak javára, amelyek cserébe Gdańsk-ot (Danzigot) „Szabad Városként” népszövetségi védelem alá helyezték. (Wilde [2008] p. 114.)
} 
terület ne veszítse el német jellegét, éppen ezért a Népszövetség a város vezetésében a helyi szervekkel osztozott. A szervezet jogosítványai csak bizonyos területekre terjedtek ki: egyrészt a Gdańsk és Lengyelország közötti vitás kérdések rendezésére, másrészt pedig a város szabad státuszát veszélyeztető lengyel alkotmányos rendelkezések megsemmisítésére. (Chesterman [2004] p. 20.) 1939. szeptember elsején a német agressziónak Gdańsk is áldozatul esett, így ismét német ellenőrzés alá került, s elkezdődött a második világháború, amely egyben a népszövetségi rendszer teljes összeomlását is jelentette.

\subsubsection{Felsö-Szilézia}

A Nemzetek Szövetségének több területi vitát is sikerült rendeznie, ezek közül az egyik legbonyolultabb a német-lengyel vegyes lakosságú, Németországhoz tartozó FelsőSzilézia esete volt. A kérdéses területen megvalósuló rendezés 1922 és 1937 között egyértelmüen a Népszövetség egyik sikereként könyvelhető el. Az elözményekröl annyit érdemes tudni, hogy 1919 és 1921 között a lengyel lakosság vezetésével FelsőSziléziában több felkelés zajlott a német uralom ellen, míg a Népszövetség végül úgy döntött, hogy népszavazást ír ki a terület hovatartozását illetően. Az 1921. márciusi referendum eredményeként a többség (60\%) a Németországhoz tartozás mellett döntött (a helyi lakosságban egyébként hozzávetőlegesen ugyanennyi, 60\% volt a németek aránya). Májusban kitört a harmadik lengyel felkelés a területen, ezután a Nemzetek Szövetsége a további vérontás megelőzése érdekében a terület megosztása mellett döntött, amelyet megerősített az 1922 májusában kötött német-lengyel megállapodás is. (Campbell [1970])

A megosztás következményeként a szénben gazdag területek Lengyelországhoz, a szénre épülő fejlett ipari területek pedig Németországhoz kerültek. Annak érdekében, hogy a korábban szervesen összefonódó ipari termelés és a gazdasági kötelékek fennilletve megmaradjanak, átmeneti időszakra (15 évre) a terület különleges státuszt nyert el: részben a helyi lengyel és német fél, részben pedig a Népszövetség irányítása alá került. Az 1922-es német-lengyel megállapodásban a felek megegyeztek, hogy a személyek szabad mozgását és az akadálymentes szénszállítást lehetővé teszik a határokon át, a Nemzetek Szövetsége pedig a megállapodás betartását felügyelte a 
felállított Vegyes Bizottság révén. ${ }^{18}$ (Chesterman [2004] pp. 21-22.) A fenti rendszer sikeresen müködött egészen 1937-ig, a nemzetiszocialista rezsim térnyerése nyomán azonban egyre inkább háttérbe szorult a kompromisszumos megoldáskeresés, $\mathrm{s}$ ismeretes, hogy Lengyelország 1939. szeptember 1-jei lerohanásához (és a második világháború kitöréséhez) az ürügyet éppen a Felső-Szilézia német részén zajló események szolgáltatták. ${ }^{19}$

A területi adminisztrációk történelmi példái sorába illeszthető, bár a szakirodalomban inkább kvázi-igazgatási példákként említik (Chesterman [2004] p. 22.) a Memelvidéken és a kolumbiai Leticiában megvalósuló beavatkozást.

\subsubsection{Memel-vidék}

A Memel-vidék hovatartozása felett éles ellentét bontakozott ki Lengyelország és Litvánia között, utóbbi számára a terület az egyetlen kijárat volt a Balti-tengerre. A versailles-i béke értelmében a Memel-vidék feletti szuverén jogairól lemondott Németország, a terület pedig ideiglenes kondomíniumként brit-francia-olasz-japán közös irányítás alá került a francia főmegbízott vezetésével. 1923 januárjában Litvánia lerohanta és elfoglalta a területet, s a fennhatóság megszerzésének eme sajátos módját végül is elfogadták a szövetséges és társult hatalmak. Az 1924. májusi Memelkonvencióban Litvánia és a szövetségesek megállapodtak abban, hogy Litvánia kizárólagos szuverenitása érvényesül a jövőben a terület felett, azonban az államnak biztosítania kell a vidék német lakosságának a kulturális autonómiát, Lengyelországnak pedig lehetővé tennie a szabad hajózást és a kikötőhasználatot. A memeli kikötőt nemzetközi területté nyilvánították, s egy irányító hatóság ${ }^{20}$ felügyelete alá helyezték, amiben a három tag egyike a népszövetségi képviselő volt (egy litván és egy helyi tag mellett). (Chesterman [2004] pp. 23-24.) Az 1924 és 1939 közötti korlátozott nemzetközi szerepvállalásnak itt is a német terjeszkedés vetett véget 1939 márciusában, amikor is a németek elfoglalták a Memel-vidéket.

\footnotetext{
${ }^{18}$ A Vegyes Bizottságban a két német és két lengyel tag mellett az elnök a Népszövetség képviseletében semleges félként volt jelen, s jogosítványai értelmében egyrészt megvétózhatott bármilyen németországi vagy lengyelországi jogszabályt, amely Felső-Szilézia kialkudott helyzetét negatívan befolyásolta volna, másrészt a végső döntés is őt illette a német-lengyel megállapodás vitás kérdéseiben.

19 A német részen fekvő Gleiwitzben müködő rádióállomásról a nácik 1939. augusztus 31-én elterjesztették, hogy azt a lengyelek a határt átlépve megtámadták (ezt alátámasztandó bizonyítékokat is hamisítottak a helyszínen), erre hivatkozással indult meg Lengyelország ellen másnap a támadás.

${ }^{20}$ International Harbour Board
} 
Megállapítható, hogy a „kvázi” jelző indokolt a nemzetközi igazgatás ezen példája esetében, hiszen a nemzetközi komponens a jogosultságok csupán szük körét birtokolta a tényleges irányításban - a kikötőt felügyelő vegyes összetételü grémium népszövetségi tagjának szerepében -, a területre pedig sokkal inkább volt jellemző a kiterjedt autonómia, mint a „nemzetköziesítés”. (Wilde [2008] p. 128.)

\subsubsection{Leticia}

A másik kvázi-adminisztráció helyszíne a dél-amerikai kontinens, itt a kolumbiai Leticiában igyekezett a Nemzetek Szövetsége a Kolumbia és Peru közötti területi vitát megoldani. Az eset sajátossága, hogy - az előbbi példákkal ellentétben - itt nem az első világháborút követő európai területi rendezés vitái miatt merült fel a Népszövetség bevonódása. (Wilde [2008] p. 128.) A szervezet szerepe mindössze abban állt, hogy beavatkozásával biztosította: egy adott terület feletti szuverenitás békés módon szálljon át egyik államról a másikra. A népszövetségi szerepvállalás előzménye az volt, hogy 1932-ben Peru lerohanta a Kolumbiához tartozó Leticiát, s a sérelmet szenvedett fél a Nemzetek Szövetségéhez fordult. A rendezés értelmében Peru egyéves átmeneti időszakra (1933-1934-ben) átadta a terület irányítását a Népszövetségnek, amely ez idő alatt a területet maga igazgatta ,a kolumbiai állam nevében” - vagyis a szuverén jogok de iure birtokosa ekkor már Kolumbia volt,$-{ }^{21}$ egy év múltán pedig a szuverenitás gyakorlása - immár de facto is - Kolumbiára szállt. ${ }^{22}$ (Chesterman [2004] p. 24.)

\subsubsection{Nemzetközi igazgatás a második világháborút követően}

\subsubsection{A gyámsági rendszer és az önkormányzattal nem rendelkezö területek}

A második világháború lezárását követően a nemzetközi területi igazgatás elsősorban két vonatkozásban értelmezhető. Egyik formája a háború lezárásához szorosan kapcsolódik, s a legyőzött, s önkormányzati jogaiktól részben vagy egészben megfosztott országokban valósult meg, jelesül Németországban, Ausztriában,

${ }^{21}$ A kolumbiai állam állta az egyéves nemzetközi igazgatás összes költségét, csapataival segítette a nemzetközi szervezet munkájában, s és a Nemzetek Szövetségének zászlaja mellett Leticiában ott lengett Kolumbiai nemzeti lobogója is. (Wilde [2008] p. 128.)

${ }^{22}$ A felek mindezt egy megállapodásban is rögzítették 1933 májusában. (Chesterman [2004] p. 24.) 
Olaszországban és Japánban. A nemzetközi igazgatás másik tevékenységi területe az önkormányzatisággal a háború előtt vagy alatt sem rendelkező területekhez kapcsolódott, dolgozatunkban csupán az utóbbiakra térünk ki.

Már a háború idején megállapodtak a későbbi győztes hatalmak - többek között az 1941-es Atlanti Chartában -, hogy a szabadságuktól megfosztott népeknek vissza kell nyerniük szuverenitásukat. ${ }^{23}$ (Churchill [1999] pp. 559-560.) Azokat a területeket azonban, amelyek a második világháború végén - és alatta - nem rendelkeztek önkormányzatisággal, mégsem kezelték egységesen a második világháborút követően. Ebben a témában az Amerikai Egyesült Államok és az Egyesült Királyság között ugyanis éles ellentét bontakozott ki, melynek lényege az volt, hogy a britek nem szerették volna, ha a Brit Birodalom részét képező területeket azonos elbánás alá veszik a mandátumrendszerből „megörökölt” és a vesztesekhez tartozó entitásokkal. Winston Churchill éppen ezért nyilvánvalóvá tette, hogy a megszállt európai területekre és a vesztesek Európán kívüli területeire alkalmazhatóak a Chartában rögzített elvek, a Föld mintegy negyedét kitevő Brit Birodalom azonban más elbánás alá kell, hogy essen. Ahogy Winston Churchill megfogalmazta: „Nem azért lettem Őfelsége miniszterelnöke, hogy a Brit Birodalom felszámolásánál elnököljek.” (Egedy [1998] p. 240.)

Ennek értelmében a függőségben levő entitások ${ }^{24}$ egyik része a népszövetségi mandátumrendszert felváltó gyámsági rendszer része lett. Az ENSZ Alapokmányának 77. cikke részletesen kitér arra, hogy a gyámsági rendszerbe a korábbi mandátumterületek, a vesztesektől elcsatolt területek, valamint azok a területek kerülnek, amelyeket az igazgatásukért felelős államok önként a gyámsági rendszer hatálya alá helyeznek. Ennek értelmében a korábbi „A”, „B” és „C” kategóriájú mandátumterületek a gyámsági rendszer részei lettek, hozzájuk csatlakozott még 1949ben a korábbi Olasz Szomáliföld, a japán mandátumterületek pedig az USA gyámsága alá kerültek. Tervezték, hogy Jeruzsálemet az ENSZ gyámsága alá helyezik, de ez az elképzelés végül nem valósult meg.

\footnotetext{
${ }^{23}$ Az Atlanti Chartában (1941. augusztus 12.) az ide vonatkozó rész: „,[...] tiszteletben tartják minden népnek azt a jogát, hogy megválaszthassa, milyen kormányzati formában kíván élni; továbbá azt kívánják, hogy helyreállítassanak mindazon népek szuverén jogai és önkormányzata, amelyeket erőszakkal fosztottak meg ezektöl.” (Churchill [1999] p. 560.)

${ }^{24}$ 1945-ben ezen területek lakosainak száma hozzávetőlegesen 750 millió fő volt. (Chesterman [2004] p. 37.)
} 
A gyámsági rendszer több tekintetben is túlmutatott a mandátumrendszer kitüzött céljain. Egyrészt már nem sorolta kategóriákba a gyámsági területeket aszerint, hogy mennyire szorulnak ,gyámkodásra” (ld. a mandátumrendszerben az „A”, „B” és „C” kategóriák), hanem mindegyik területre vonatkozott az Alapokmány 76. cikk b. bekezdése, miszerint a gyámsági rendszer célja az önkormányzatiság fejlesztése vagy a függetlenség előmozdítása. ${ }^{25}$ Szintén különbség, hogy a gyámságot gyakorló hatalmak felett szorosabb ellenőrzést gyakorolt a Gyámsági Tanács, amely szerv jelentőségét mutatja az a tény is, hogy az ENSZ főszervei közé sorolták a szervezet alapításakor. A Tanács elsősorban a kötelezően benyújtandó jelentéseken keresztül ellenőrizte a gyámságot gyakorló hatalmakat, de - jelentős eltérés a mandátumrendszerhez képest, hogy - a gyámság alá volt területek lakossága petícióval is fordulhatott a Gyámsági Tanácshoz, amelynek jogában állt ellenőrző missziókat küldeni az adott területre. (Chesterman [2004] pp. 38-40.) A gyámsági rendszer 1945 és 1994 között müködött, ezalatt mind a 11 gyámsági terület függetlenedett, ${ }^{26}$ éppen ezért jelenleg a Gyámsági Tanács inaktív intézmény.

A gyámság alá nem volt többi, ún. önkormányzattal nem rendelkező terület - így a Brit Birodalomhoz tartozó számos entitás - sorsáról az Alapokmány 73. cikke ${ }^{27}$ rendelkezik,

${ }^{25}$ A gyámsági rendszer alapvető célja „,[...] előmozdítani a Gyámság alatt álló területek lakosságának politikai, gazdasági, szociális előrehaladását, valamint a nevelésügy fejlesztését; továbbá a fokozatos haladást az önkormányzati képesség vagy függetlenség felé, tekintetbe véve az egyes területek és népek különleges viszonyait, az érdekelt népesség szabadon nyilvánított akaratát, valamint a Gyámságra vonatkozó egyes megállapodások megfelelő rendelkezéseit; [...]”(Halmosy [1985] pp. 19-44.)

${ }^{26}$ A gyámsági területek (zárójelben a gyámságot gyakorló hatalom) sorsának alakulása: 1) Brit-Togó (Nagy-Britannia) a brit tulajdonú Aranyparttal egyesült 1957-ben Ghána néven; 2) Francia-Togó (Franciaország) 1960-ban Togó néven függetlenedett; 3) Olasz Szomáliföld (Olaszország) Brit Szomálifölddel egyesült Szomália néven 1960-ban; 4) Francia Kamerun (Franciaország) 1960-ban független Kamerun lett, 1961-ben a terület kiegészült a Brit Kamerun déli részével; 5) Tanganyika (NagyBritannia) 1961-ben függetlenedett, majd 1964-ben Zanzibárral egyesülve Tanzánia lett; 6) NyugatSzamoa (Új-Zéland) 1962-ben lett független, 1997-töl a neve Szamoa; 7) Ruanda-Urundi (Belgium) helyén 1962-ben két független állam jött létre, Ruanda és Burundi; 8) Nauru (Ausztrália) 1968-ban lett független; 9) Új-Guinea (Ausztrália) Pápuával egyesülve 1975-ben létrehozta Pápua-Új-Guineát; 10) a Csendes-óceáni Gyámsági Terület (USA) Palau kivételével 1986-ban feloszlott: az Északi-Marianaszigetek az USA fennhatósága alá kerültek, a Marshall-szigetek és a Mikronéziai Szövetségi Államok az USA társult államaként független államok lettek; 11) Palau (USA) 1994-ben függetlenedett, de továbbra is az USA társult állama maradt. (Chesterman [2004] pp. 40-41.)

27 „XI. fejezet: Önkormányzattal nem rendelkező területekre vonatkozó nyilatkozat

73. cikk

Egyesült Nemzeteknek azok a tagjai, amelyek olyan területek igazgatásáért vállaltak vagy készek vállalni a felelősséget, amely területek népei az önkormányzat mértékét még nem érték el, elismerik e területek lakossága érdekei elsőbbségének alapelvét. Magasztos megbízatásnak tekintik azt a kötelességüket, hogy a nemzetközi békének és biztonságnak a jelen Alapokmánnyal létesített rendje keretében e területek lakosságának jólétét tőlük telhetőleg előmozdítsák és ebből a célból 
ebben az igazgatásért felelős államok vállalnak meghatározott - ám csupán általánosságokban megfogalmazott - kötelezettségeket. (Halmosy [1985] pp. 19-44.) A 77. cikk szerinti gyámsági rendszer alá helyezett, s a 73. cikk szerinti önkormányzattal nem rendelkező területek közti legfőbb különbség abban áll, hogy előbbiek kapcsán egyértelmü cél volt a területek függetlenségének biztosítása, utóbbiaknál viszont az igazgatásért felelös állam diszkrecionális joga volt arról dönteni, hogy milyen fokú önállóságot biztosít az irányítása alatt álló entitásnak. (Chesterman [2004] p. 38.) Megváltozott azonban a helyzet az ötvenes és hatvanas évek fordulójára, amikorra egyértelmüen látszott, hogy a dekolonizációs hullámot nem lehet feltartóztatni. Az ENSZ Közgyülés 1960. december 14-én fogadta el 1514. (XV) számú határozatát „Nyilatkozat a gyarmati országoknak és népeknek nyújtandó függetlenségről” címmel (röviden csak dekolonizációs határozatként utalunk a dokumentumra), ${ }^{28} \mathrm{~s}$ ebben hitet tett amellett, hogy az önrendelkezés sokkal inkább jog, semmint elv, s a függésben levő területek népeinek joga van eldönteni, hogy milyen rendszerben kívánnak élni. A dekolonizációs folyamat előmozdítása érdekében az ENSZ létrehozta a Dekolonizációs Bizottságot, ${ }^{29}$ mára pedig 16 kivétellel $^{30}$ az összes önkormányzattal nem rendelkező terület elnyerte függetlenségét.

a) az érdekelt népek kultúrája tiszteletben tartásának kötelezettségével biztosítsák azok politikai, gazdasági, szociális előrehaladását, nevelésügyük fejlesztését, az igazságos bánásmódot velük szemben és védelmüket a visszaélések ellen;

b) az egyes területek és népeik különleges viszonyainak és elörehaladottságuk különböző fokának megfelelően kifejlesszék ezek önkormányzati képességét, vegyék tekintetbe a szóban levő népek politikai törekvéseit és támogassák őket szabad politikai intézményeik fokozatos kifejlesztésében;

c) elősegítsék a nemzetközi békét és biztonságot;

d) előmozdítsák a fejlődést segítő intézkedéseket, támogassák a kutató munkát, együttmüködjenek egymással és ha szükséges, a szakosított nemzetközi szervezetekkel abból a célból, hogy a jelen cikkben felsorolt szociális, gazdasági és tudományos célok a gyakorlatban is megvalósulást nyerjenek és

e) a Főtitkárnak tájékoztatás céljából, a biztonság és az alkotmányjogi meggondolások által megkívánt határokon belül, rendszeresen statisztikai és más technikai természetủ tájékoztatásokat nyújtsanak azoknak a területeknek gazdasági, szociális és nevelésügyi helyzetére vonatkozóan, amelyekért különkülön felelősek, kivéve azokat a területeket, amelyekre a XII. és XIII. fejezetek rendelkezései vonatkoznak." (Halmosy [1985] pp. 19-44.)

${ }^{28}$ Declaration on the granting of independence to colonial countries and peoples

${ }^{29}$ Hivatalos nevén: Special Committee on Decolonization, de használatos még a Committee of 24 kifejezés is az intézményre.

30 Jelenleg 16 önkormányzattal nem rendelkezö területet tart számon az ENSZ, ezek a következök (zárójelben az igazgatásért felelős állam): 1) Amerikai Szamoa (USA); 2) Amerikai Virgin-szigetek (USA); 3) Anguilla (Nagy-Britannia); 4) Bermuda (Nagy-Britannia); 5) Brit Virgin-szigetek (NagyBritannia); 6) Falkland-szigetek (Nagy-Britannia); 7) Gibraltár (Nagy-Britannia); 8) Guam (USA); 9) Kajmán-szigetek (Nagy-Britannia); 10) Montserrat (Nagy-Britannia); 11) Nyugat-Szahara (vitatott, Marokkó vagy a helyi Polisario Front); 12) Pitcairn-szigetek (Nagy-Britannia); 13) Szent Ilona (NagyBritannia); 14) Tokelau-szigetek (Új-Zéland); 15) Turks- és Caicos-szigetek (Nagy-Britannia); 16) ÚjKaledónia (Franciaország). (UN [é. n./a]) 
A második világháború utáni nemzetközi rendszer szabályozási kereteinek felvázolása után a továbbiakban sorra vesszük a nemzetközi területi igazgatás példáit 1945 után. Ahogyan azt korábban is jeleztük, tekintettel arra, hogy a nemzetközi adminisztráció esetei többféleképpen csoportosíthatók, az alábbiakban kronológiai sorrendben haladunk az egyes példák bemutatásánál, s a következő (1.4.) fejezetben vállalkozunk az igazgatási modellek osztályozására.

\subsubsection{Kongó}

A kongói konfliktus rögtön azután tört ki, hogy a belgák kivonulásával 1960-ban függetlenedett az ország. A zavargások hamarosan az egész országra kiterjedtek, a katangai és dél-kasai részek elszakadást fontolgattak - előbbi éppen az országban maradó belga erők hathatós támogatásával,$-{ }^{31}$ a politikai vezetők kiéleződő szembenállása ellehetetlenítette az egységes irányítást, az ország pedig mindeközben egyre sodródott az anarchia felé. Az ENSZ meglehetősen gyorsan és hatékonyan reagált az eseményekre, 1960. július 14-én az ENSZ Biztonsági Tanácsa elfogadta a 143. számú határozatot, (S/RES/143 [1960]) amely segítséget ígért a kongói kormánynak a rend helyreállításában, felügyelte az akkor már jogellenesen Kongóban tartózkodó belga csapatok kivonulását és technikai segítségnyújtást ígért. Az $\mathrm{ONUC}^{32}$ telepítése a $\mathrm{BT}$ határozat elfogadását követően 48 órán belül megkezdődött, s igen nagyszámú, mintegy 20 ezer fös kontingens érkezését jelentette. (UN Peacekeeping Operations, - ONUC [é. n.]) A kezdetben elöirányzott, viszonylag egyszerü mandátumot ki kellett később terjeszteni, tekintettel a bonyolult körülményekre.

$\mathrm{Az}$ ONUC a területi adminisztrációk vizsgálatánál mindenképpen mérföldkőként tartható számon, egyrészt a misszióban részt vevők magas létszáma miatt, másrészt pedig azért, mert a katonai jelenlét civil funkciókkal is kiegészült. A polgári igazgatás legfőbb feladata az volt, hogy kitöltse a sietve távozó belgák után hagyott igazgatási ürt, erre a nehezen felálló, s belső viszályaival foglalatoskodó kongói vezetés ugyanis nem volt képes. Az ONUC sikereit azonban elhomályosítja egyrészt, hogy az ENSZ ebben a misszióban elsőként tapasztalta meg nagyszámú alkalmazottjának - mintegy 250 főnek,

${ }^{31}$ A belgáknak jelentős gazdasági éredekeltségeik voltak Kongóban, ezek sorsa vált kérdésessé a függetlenedést követően.

32. Organisation des Nations unies au Congo - ONUC, angol elnevezése: The United Nations Organization in the Congo. Az elnevezés 1963-tól: Opération des Nations unies au Congo. 
köztük Dag Hammarskjöld ENSZ főtitkárnak - az elvesztését, másrészt pedig az a tény, hogy az ENSZ 1964-es kivonulását követően a Mobutu Sese Seko által müködtetett kleptokrácia sem hozott békét a kongóiaknak. (Chesterman [2004] p. 84.)

\subsubsection{Nyugat-Új-Guinea (Pápua)}

Nyugat-Új-Guinea 1828 óta Hollandia tulajdonában volt, s a hovatartozása akkor vált kérdésessé, amikor 1948-ban Hollandia elismerte a független Indonéziát. Indonézia ezt követően folyamatosan vitatta a holland jelenlétet Nyugat-Új-Guineán, mivel szerinte a terület a 17. századtól Indonézia részét képezte, ezért a hollandoknak át kellene azt adniuk az újonnan függetlenedett államnak. (UN Peacekeeping Operations - UNSF [é. n.]) A kérdésben nem tudtak megegyezni az érintettek, ezért az ENSZ-hez fordultak, ahol több évig napirenden volt a kérdés, a megegyezésre végül a főtitkár jószolgálati és az ENSZ kitartó közvetítői tevékenysége eredményeként került sor. Hollandia és Indonézia 1962. augusztus 15-én tüzszüneti megállapodást írt alá, (Gruss [2005] pp. 117-126.) az ENSZ Közgyülése pedig ugyanezen év szeptember 21-én - egy nappal a tüzszüneti megállapodás ratifikációjának lezárulása után - elfogadta a rendezést célzó 1752-es számú határozatát, (A/RES/1752(XII) [1962]) amely tudomásul vette a felek közti megállapodás létrejöttét és felhatalmazta a főtitkárt a megfelelő intézkedések megtételére.

A megállapodás értelmében Nyugat-Új-Guinea igazgatása az ENSZ Ideiglenes Végrehajtó Hatóságára (United Nations Temporary Executive Authority - UNTEA) száll át 1962. október 1. és 1963. május 1. között, ezután pedig Indonézia kapja meg a terület feletti adminisztrációs jogot. (Chesterman [2004] p. 66.) Az UNTEA feladata tehát az volt, hogy hét hónapos átmeneti időszakra - amíg a Nyugat-Új-Guinea feletti fennhatóság át nem száll Hollandiáról Indonéziára - teljes körűen igazgassa a területet, garantálja a jog uralmát és a biztonságot, valamint az emberi jogok érvényesülését. Az UNTEA munkáját segítette az idevezényelt, mintegy 1500 fős ENSZ-kontingens, az UNSF (United Nations Security Force) is, amely elsősorban a hollandok kivonulásáért, a tüzszünet betartásáért és a biztonságos körülményekért felelt. (Gruss [2005] p. 107.) 
Az ENSZ szerepvállalása sikeresnek tekinthető, hiszen az UNTEA (az UNSF-fel) elvégezte a feladatát, $s$ a terület feletti igazgatás jogát átadta a meghatározott időben Indonéziának. Ezt követően az UNTEA kivonult a térségből.

Az 1962-es indonéz-holland megállapodás arról is rendelkezett (ld. XVIII. cikk), hogy Indonézia az ENSZ főtitkár által kinevezett megbízottal együtt biztosítja, hogy a nyugat-új-guineaiak szabadon véleményt nyilvánítsanak arról, hogy Indonéziával vagy nélküle képzelik el a jövőjüket. A megállapodás nem rögzíti e véleménynyilvánítás pontos kereteit és körülményeit, de tény, hogy az indonéz kormányzat ebben a témában nem engedett beleszólást az ENSZ-megbízottnak. Utóbbi ugyanis a népszavazás kiírását támogatta, ahol a lakosok egyénenként nyilváníthattak volna véleményt, az indonéz fél viszont - hagyományaira hivatkozva - azt a megoldást választotta, hogy a nép helyett annak képviselőivel nyilváníttatott véleményt: a képviselő testületeket ${ }^{33}$ szavaztatta meg 1969. július 14. és augusztus 2. között, amelyek egyöntetűen az Indonéziához tartozás mellett voksoltak. ${ }^{34}$ Az ENSZ megbízottja végül jelentésében elfogadásra javasolta a tradicionális indonéz megoldást, de sajnálatát fejezte ki amiatt, hogy a kormány nem teljesítette vállalt kötelezettségét a szabad véleménynyilvánítás területén, mert szoros politikai ellenőrzés alatt tartotta a pápuai lakosságot. (Chesterman [2004] p. 67.)

\subsubsection{Namíbia}

A későbbiekben Namíbiának nevezett Délnyugat-Afrika az első világháború után mandátumterületként Dél-Afrikához került. A második világháborút követően az ENSZ döntött arról, hogy a megszünt mandátumrendszer területeit átviszik a gyámsági rendszerbe; Dél-Afrika volt az egyetlen a korábbi mandatáriusok közül, amely ezt visszautasította Délnyugat-Afrika esetében.

Az ENSZ-ben a következő évtizedekben szinte folyamatosan napirenden volt az ún. délnyugat-afrikai ügy, érdemi elörelépés azonban sokáig nem történt. 1950-ben a

\footnotetext{
${ }^{33}$ representative councils vagy consultative assemblies

${ }^{34} \mathrm{Ha}$ valóban a nyugat-új-guineai lakosságot szavaztatják meg, korántsem biztos, hogy ugyanez az eredmény született volna, az emberek valószínüleg Indonézia ellen voksoltak volna. Az UNTEA kivonulását követően ugyanis az indonéz kormányzat - hatalma megszilárdítása érdekében - számos megszorító intézkedést léptetett életbe, többek között a szólás- és sajtószabadságot korlátozta. (Gruss [2005] p. 112.)
} 
Nemzetközi Bíróság tanácsadó véleményében ${ }^{35}$ tulajdonképpen elfogadta Dél-Afrika érvelését - miszerint szuverén államként, amely nem volt alapító tagja a világszervezetnek (1945 novemberében csatlakozott végül), nem kényszeríthető arra, hogy a gyámsági rendszerbe vigye Dél-Afrikát -, s arra az álláspontra helyezkedett, hogy Délnyugat-Afrika esetében Dél-Afrika tegyen eleget a továbbiakban is mandatáriusi kötelezettségeinek (annak ellenére, hogy sem a Népszövetség, sem a mandátumrendszer már nem létezett) és nyújtson be éves jelentést az ENSZ-nek arról, miként igazgatja a rábízott területet. (Matz [2005] p. 79.) Dél-Afrika egyetlen jelentést sem nyújtott be az ENSZ-nek.

1960-ban Libéria és Etiópia keresetet nyújtott be a Nemzetközi Bíróságon Dél-Afrika ellen, miszerint nem teljesíti mandátumos kötelezettségeit, saját államterülete részeként bánik Délnyugat-Afrikával, kiaknázza természeti erőforrásait és kiterjeszti rá az apartheid-rendszert. A Bíróság 1966-os döntésében ${ }^{36}$ kétségbe vonta, hogy Etiópiának és Libériának közvetlen érdekei füződnének Délnyugat-Afrika sorsának alakulását illetően, így a keresetet nem találta megalapozottnak és elutasította, mindazonáltal megállapította, hogy Dél-Afrika valóban nem teljesíti a korábban számára előírt kötelezettségeket. (Matz [2005] p. 80.) Éppen ezért a Közgyülés úgy döntött, (A/RES/2145(XXI) [1966]) hogy Délnyugat-Afrika nem tekinthető mandátumterületnek többé, felette az igazgatást a függetlenség eléréséig az ENSZ gyakorolja a továbbiakban, 1967-ben létre is jött az ENSZ Délnyugat-afrikai Tanácsa (United Nations Council for South West Africa), amit egy évvel később átneveztek az ENSZ Namíbiai Tanácsának (United Nations Council for Namibia).

A hatvanas-hetvenes években a Biztonsági Tanács is többször napirendjére vette a délnyugat-afrikai ügyet, s a BT, a Közgyülés és a Nemzetközi Bíróság is több alkalommal megállapította, hogy Dél-Afrika jogellenesen jár el, mert nem veszi figyelembe az ENSZ különböző szerveinek döntéseit, $\mathrm{s}$ továbbra is sajátjaként birtokolja a délnyugat-afrikai területet. (UN Peacekeeping Operations - UNTAG [é. n.]) Mindeközben 1960-tól a formálódó namíbiai erők elkeseredett harcot vívtak a sokkal tapasztaltabb és szervezettebb dél-afrikai katonasággal.

${ }^{35}$ A tanácsadó vélemény teljes szövegét ld: Advisory Opinion of 11 July 1950 - International Status of South West Africa (including the text of the declaration of Judges Guerrero, Zoricic et Badawi Pasha)

${ }^{36}$ A döntés teljes szövegét ld: Judgment of 18 July 1966 - South West Africa (Liberia v. South Africa) és Judgment of 18 July 1966 - South West Africa (Ethiopia v. South Africa) 
1978-ban az ún. Nyugati Összekötő Csoport ${ }^{37}$ állt elő azzal az ötlettel, hogy tartsanak választásokat és állítsanak fel alkotmányozó nemzetgyülést Namíbiában, s e folyamatokat az ENSZ különleges namíbiai megbízottja és az őt segítő helyi ENSZmisszió felügyelje. 1978. szeptember 29-én az ENSZ BT 435-ös határozatával döntöttek az UNTAG (United Nations Transition Assistance Group) felállításáról, (S/RES/435 [1978]) amely azonban csaknem egy évtizeddel később kezdte csak meg müködését. Dél-Afrika ugyanis nem adta hozzájárulását az ENSZ-misszió namíbiai telepítéséhez.

1980-ban végül Dél-Afrika hajlandó volt tárgyalóasztalhoz ülni a Nyugati Összekötő Csoport nyomásának engedve, engedményekre azonban továbbra sem hajlott, sőt újabb feltételt támasztott, amellyel újabb évekre visszavetette a megegyezés lehetőségét: kinyilvánította ugyanis, hogy abban az esetben hajlandó erőit visszavonni Namíbiából, ha Kuba is kivezényli csapatait Angolából. 1988-ban végül Dél-Afrika, Angola és Kuba megállapodtak $^{38}$ abban, hogy 1989 áprilisában az UNTAG Namíbiába települ, ugyanekkor az UNAVEM (United Nations Angola Verification Mission) Angolában kezdi meg a kubai csapatok kivonulásának felügyeletét. (Chesterman [2004] p. 60.)

Az UNTAG meglehetősen komplex feladatokat ellátó misszió volt, tevékenysége civil és katonai komponensre tagolódott, ezekben 124 ország küldöttei teljesítettek szolgálatot, az ENSZ különleges megbízottjaként pedig a finn Marti Ahtisaari mindkettőt felügyelte és irányította. A polgári komponens egyik legfontosabb pillére a mintegy 1500 fős rendőri kontingens volt, ők ellenőrizték a helyi biztonsági erőket, s biztosították a választások konfliktusmentes lebonyolítását. (UN Peacekeeping Operations - UNTAG [é. n.]) A választásokra 1989 novemberében került sor - s a várakozásoknak megfelelően a $\mathrm{SWAPO}^{39}$ nyerte el a szavazatok többségét -, novemberben felállt az alkotmányozó nemzetgyülés, amely 1990 elején elfogadta az ország alkotmányát. Namíbia 1990. március 21-én nyerte el függetlenségét.

\footnotetext{
${ }^{37}$ Az 1977-ben a namíbiai rendezés előmozdítása céljából alakult csoport tagjai: az Amerikai Egyesült Államok, Franciaország, Kanada, Nagy-Britannia, NSZK.

${ }^{38}$ Agreement Among the People's Republic of Angola, the Republic of Cuba, and the Republic of South Africa.

${ }^{39}$ Délnyugat-afrikai Népi Szervezet (South-West African People's Organization)
} 


\subsubsection{Nyugat-Szahara}

Nyugat-Szaharát a 19. századtól 1976-ig a spanyolok birtokolták, akik, mielőtt kivonultak, 1975-ben titkos megállapodásban egyeztek meg Nyugat-Szahara két szomszédjával, Marokkóval és Mauritániával a terület felosztásáról a két állam között. Hiába kiáltották ki a Szaharai Arab Demokratikus Köztársaság létrejöttét 1976 februárjában, a két szomszédos állam bevonult Nyugat-Szaharába még ugyanebben az évben, ekkor vette kezdetét az az elkeseredett harc, amit az itt élő nép, a szahravik vívnak a megszállók ellen. Mauritánia 1979-ben kivonult, Marokkó azonban tovább terjeszkedett, s mivel képtelen volt teljes győzelmet aratni a szahravikat képviselő Polisario Front (Frente Popular de Liberación de Saguía el Hamra y Río de Oro) felett, ezért a nyolcvanas években egy több, mint $2400 \mathrm{~km}$ hosszú falat épített NyugatSzaharában, amely végighúzódva az országon, elválasztja egymástól a nyugati, Marokkó által megszállt területeket és a keleti, a Polisario Front irányítása alatt levő részeket. A szahravi lakosság túlnyomó része az ország megszállás alatt álló részén él, azzal a több százezer telepes marokkóival együtt, akiket az ún. „zöld menet” keretében és azt követően telepített az országba Marokkó az etnikai arányok megváltoztatása érdekében. Az országnak ez a fele rendelkezik egyébként Nyugat-Szahara természeti kincseivel is - föként értékes foszfátlelőhelyekkel, valamint a halban és feltehetően kőolajban és földgázban is gazdag atlanti-óceáni partszakasszal -, a Polisario Front ellenőrizte részek viszont alig lakott sivatagos részek. A Front legfőbb bázisa és egyben támogatója Algéria, a megszállást követően ide menekültek a szahravik tízezrei, akik azóta is az itteni menekülttáborokban élnek, létszámuk 100 és 200 ezer közé tehető. (Jensen [2005] p. 14.)

Az ENSZ fơtitkárának jószolgálati missziója és az Afrikai Egységszervezet (később Afrikai Unió) 1985 óta igyekszik megállapodásra bírni a feleket, akik 1988-ban alá is írtak egy ún. „rendezési javaslatot”. Ezt az ENSZ főtitkára 1990 nyarán be is nyújtotta a Biztonsági Tanácsnak a megállapodásban foglaltak végrehajtására vonatkozó elképzeléseivel együtt. ${ }^{40} \mathrm{~A}$ dokumentum lényege az volt, hogy a feleknek a tüzszünetre vonatkozó megállapodását követően az ENSZ szervezésében és felügyeletével

\footnotetext{
${ }^{40}$ A fötitikár által jegyzett dokumentum címe: The Situation Concerning Western Sahara. Report of the Secretary General. 18 June 1990. Később Pérez de Cuéllar kiegészítette az 1990-es jelentésében írottakat (The Situation Concerning Western Sahara. Report of the Secretary General. 19 April 1991.)
} 
népszavazást tartanak, amelyen a nyugat-szaharai lakosság kinyilváníthatja akaratát, hogy független államban kívánnak-e élni, vagy egyesülnének inkább Marokkóval. A BT 690. számú határozatával létre is hozta a MINURSO-t (United Nations Mission for the Referendum in Western Sahara), (S/RES/690 [1991]) valamint egy 1991 szeptemberétől tartó átmeneti időszakra különleges megbízottat nevezett ki, aki minden, a referendummal kapcsolatos döntésben illetékes volt. A népszavazás tervezett időpontja 1992. januárra esett, de már a MINURSO helyszínre telepítése is akadályokba ütközött, s a misszió végül az eredetileg tervezett létszám egy tizedével (mintegy 100 fővel), a fegyverszünet betartásának ellenőrzésére érkezett meg Nyugat-Szaharába. (UN Peacekeeping Operations - MINURSO [é.n.])

Hamarosan kiderült, hogy a megállapodás, amelyre hivatkozással az egész ENSZmisszió létrejött, korántsem jelent szilárd alapot az együttmüködéshez. Az 1991 szeptemberében hatályba lépő tüzszünetet a felek többször megsértették, de még ennél is nagyobb problémát jelentett, hogy Marokkó és a Polisario Front vég nélküli vitába kezdett arról, hogy kik a választásra jogosultak. Marokkó álláspontja szerint minden olyan személy, aki Nyugat-Szaharában él - ez elfogadhatatlan volt a Polisario Frontnak, mert a mintegy félmilliós lakosság túlnyomó részét a marokkói telepesek adták, akik nyilvánvalóan a Marokkóval való egyesülés mellett szavaztak volna. A Polisario Front érvelése szerint a választásra csakis a szahravik jogosultak, vagyis azok, akik NyugatSzaharában maradtak, és azok is, akik elmenekültek a szomszédos országokba. A MINURSO 1993 májusában felállított a választásra jogosultak regisztrációjára egy bizottságot (Identification Committee), 1996 májusában azonban felfüggesztette ennek tevékenységét, mivel a felek nem hajlottak a kompromisszumra. ${ }^{41}$

A MINURSO a nemzetközi beavatkozások sorában egyértelmüen sikertelen kísérletként van jelen, egy olyan próbálkozásként, amely beleragadt a felek technikai kérdésekről folytatott vitának álcázott időhúzási törekvéseibe (ld. szavazásra jogosultak körének megállapítása). A misszió sikertelenségének azonban más okai is vannak, legföképpen az az általános érdektelenség, ami megmutatkozott a kérdés irányában a potens hatalmak részéről. Érdekes adalékot közöl a témához Chesterman, amikor leírja Goulding memoárjára hivatkozva -, hogy 1997-ben az akkori ENSZ különleges

\footnotetext{
${ }^{41}$ 1997-ben újra munkába állt a Bizottság, és a választásra jogosultak számbavételét 1998-ban le is zárta, de sem Marokkó, sem a Polisario Front nem engedett követeléseiből.
} 
megbízott, James Baker mit válaszolt a Polisario Front képviselőjének kérdésére, amikor az illető azt firtatta, hogy miért nem kezeli a kelet-timorihoz hasonlóan a nyugat-szaharai ügyet az ENSZ. Baker válasza az volt, hogy akkor részesülnek majd azonos elbánásban a kelet-timoriakkal a szahravik, ha találnak ők is maguknak egy Ausztráliát, amely hajlandó akár katonailag is beavatkozni az érdekükben. ${ }^{42}$ (Chesterman [2004] p. 70.)

A MINURSO a mandátumában eredetileg előirányzott feladatoknak csak egy részét végezte el, valóban hatékonyan hozzájárult a fegyverszünet ellenőrzéséhez, és számos programot indított a szétszakított szahravi családok érdekében. Elsődleges feladatához azonban, a népszavazás megszervezéséhez, még nem tudott hozzákezdeni. A kétezres évek második felében a vitában álló felek ismét tárgyalóasztalhoz ültek, ez idáig áttörés nem történt.

\subsubsection{Kambodzsa}

Kambodzsa 1953-ban nyerte el függetlenségét Franciaországtól, az ezt követő évtizedek során a lakosság elszenvedte a belpolitikai hatalmi játszmák következményeit, de a legnagyobb szenvedést a kambodzsai társadalomra a Vörös Khmer uralma hozta 1975 és 1979 között. A Pol Pot vezette rezsim nemcsak társadalmi pozíció alapján, hanem az etnikai hovatartozás okán is üldözte az ország lakosait: a nagyszámú kínai és vietnámi kolónia lélekszáma az évtized végére töredékére apadt az üldöztetések következtében. A kommunista rezsim a vietnámiakat a rendszer megdöntésére törekvő ,átszivárgó” elemeknek tekintette, $s$ többször intézett támadásokat vietnámi területek ellen is. (Keller [2005] p. 135) Többek között ez is volt az oka annak, hogy végül a szomszédos Vietnam intervenciója véget vetett 1978 végén a vörös khmerek uralmának, amelynek során több, mint egymillió ember lelte halálát a „gyilkos mezőkön”, az átnevelő táborokban vagy a börtönökben.

\footnotetext{
${ }^{42}$ Az Amerikai Egyesült Államok és Franciaország a vitában Marokkót támogatja. Nem véletlen, hogy az ENSZ köreiben is - amely pedig eredetileg támogatta a szahravik ügyét - egyre inkább elterjedt az a vélekedés a kétezres években, hogy a legéletszerübb megoldás a nyugat-szaharai ügy rendezésére az lenne, ha a terület Marokkóhoz tartozna, és kiterjedt autonómiajogokat kapna azon belül. Éppen az amerikai James Baker volt az, aki különleges nyugat-szaharai megbízottként elöállt ezzel a javaslattal 2001-ben.
} 
A harcok azonban nem szüntek meg a vietnámi intervenciót követően, a defenzívába szorult vörös khmerek tovább harcoltak, s a nyolcvanas években is végig polgárháborús állapotok uralkodtak az országban. Mindeközben az ENSZ a nyolcvanas években több sikertelen kísérletet tett a helyzet rendezésére, és igyekezett humanitárius segítséget nyújtani a szenvedő lakosságnak. 1989 tavaszán végül Vietnam bejelentette, hogy kivonul Kambodzsából, katonái novemberre el is hagyták az országot. 1991. október 23-án a párizsi megállapodás ${ }^{43}$ véget vetett a konfliktusnak, s létrehozta a Legfelsőbb Nemzeti Tanácsot mint az állami hatalom legfőbb birtokosát, amely aztán felhatalmazta az ENSZ-et, hogy a megállapodás betartatását minden szükséges eszközzel biztosítsa. (Chesterman [2004] p. 74.)

Az ENSZ Biztonsági Tanácsa a 745. számú határozatával létrehozta az UNTAC-ot (United Nations Transitional Authority in Cambodia), (S/RES/745 [1992]) amelynek feladata volt a tüzszünet és a külföldi csapatok kivonásának ellenőrzése; a kambodzsai fegyveres alakulatok leszerelése; a közigazgatás ellenőrzése és felügyelete, ideértve a rendőri erőket is; az emberi jogok érvényre juttatása és a szabad választások lebonyolítása. Az UNTAC létszáma a misszió müködése alatt 15000 és 22000 fö között mozgott, akik több mint 100 államból érkeztek, a nemzetközi jelenlét gerincét a mintegy 3600 fös nemzetközi rendőri kontingens adta. A sikeresnek értékelhető választásokat 1993 májusában tartották, ezután az UNTAC kivonult Kambodzsából. (UN Peacekeeping Operations - UNTAC [é. n.])

\subsubsection{Szomália}

Szomália 1960-ban lett független, amikor egyesítették a korábbi Brit Szomáliföldet Olasz Szomálifölddel, s így Afrika egyik etnikailag leginkább homogén állama jött létre. 1969-ben vértelen puccsal Sziad Barré vette át a hatalmat, s egészen 1991-ig vezette az országot az ún. tudományos szocializmus ideológiájának szellemiségében. A rezsim 1977-ig baráti viszonyt ápolt a Szovjetunióval, a szakításhoz az vezetett, hogy a SZU a Szomália és Etiópia között zajló 1977-1978-as ogadeni háborúban az etiópok mellé állt. ${ }^{44}$ Az expanzív szándékokkal és a Nagy-Szomália elképzelés megvalósítása

\footnotetext{
${ }^{43}$ Agreement on a Comprehensive Political Settlement of the Cambodia Conflict.

44 Etiópia és Szomália között a viszony hagyományosan feszült volt. Etiópiában (több más környező országhoz hasonlóan) jelentős számú szomáli népesség él. Az etióp-szomáliai háborúkban az etiópiai
} 
céljából indított háború Szomália vereségével végződött. A nyolcvanas években az ország egyértelműen az USA érdekszférájába került, s csak az amerikai fél segítségével sikerült területi integritását megőriznie az 1982-es etióp-szomáliai határháborúban. (Phillip [2005] p. 522.)

Mindeközben Szomália nem volt mentes a belső feszültségektől sem. Már a nyolcvanas években elkezdtek szerveződni a Sziad Barré-ellenes csoportok, amelyeknek 1991-ben sikerült megbuktatniuk az elnököt. Hamarosan ezután egymás ellen fordultak a felkelő csoportok és 1991-től gyakorlatilag máig tartó polgárháborúba sodorták az országot és annak lakosságát. A küzdelem hamarosan két szembenálló csoport között zajlott, az egyiket a szomáliai ideiglenes elnök, Ali Mahdi, a másikat pedig Farrah Aidid katonai vezető irányította. A hatalmat egyiküknek sem sikerült megszerezni, az ország azonban anarchikus állapotba süllyedt, s a regionális nemzetközi szervezetek - úgymint az Afrikai Unió, az Arab Államok Ligája és az Iszlám Konferencia Szervezete - megoldási kísérletei sem vezettek eredményre. (UN Peacekeeping Operations - UNOSOM I. [é. n.])

A lakosság szenvedéseit és az egyre kritikusabb ellátási nehézségeket súlyosbította az aszály, s mindez éhínséghez és 300000 ember halálához vezetett. A szomáliak nagy számban menekültek az országon belül és azon kívülre is: a belső menekültek száma 1,7 millióra tehető, az országot pedig hozzávetőlegesen kétmillióan hagyták el. (Phillip [2005] p. 524.) A nemzetközi segélyszervezetek tehetetlenek voltak, hiába érkeztek meg az országba a szállítmányok, azok a folyamatos fosztogatások és rablások, a közutak állapota és a veszélyes környezet miatt a legritkább esetben jutottak el az éhezőkhöz.

Az ENSZ csak ezek után kezdett foglalkozni a szomáliai üggyel, ennek kapcsán fel is merült a világszervezettel szemben a kettős mérce vádja, miszerint a balkáni eseményekre ekkoriban sokkal nagyobb figyelmet fordított, mint az Afrika szarván zajló eseményekre. A humanitárius katasztrófa ténye ekkorra nyilvánvalóvá vált, a szomáliai események már a térség békéjét és biztonságát is veszélyeztették, a regionális szervezetek pedig nem értek el kézzelfogható eredményt. Az ENSZ-nek (a fentebb említett regionális szervezetekkel együtt) végül sikerült a feleket tárgyalóasztalhoz

szomáli törzsek belülről igyekeztek destabilizálni Etiópiát és segíteni Szomáliát. 
ültetni és rávenni őket egy tűzszüneti egyezmény aláírására. Ezt követően az ENSZ BT 751. számú határozatával 1992 áprilisában létrehozta az UNOSOM-ot (United Nations Operation in Somalia), (S/RES/751 [1992]) amely a tüzszünet betartását ellenőrző 50 katonai megfigyelőjével települt Szomáliába. Később mintegy 3000 fős biztonsági alakulat érkezett az országba, amelynek feladata a humanitárius segélyszállítmányok célba juttatása volt, de az egyre romló körülmények között az UNOSOM tehetetlennek bizonyult. Az éhezések miatt közvetlen életveszélyben levők száma másfél millióra emelkedett, számos új fegyveres frakció jelent meg, amelyek felett Mahdi és Aidid sem tudott ellenőrzést gyakorolni, utóbbi ráadásul egyre nyíltabban szembehelyezkedett az ENSZ-szel.

1992 novemberében az USA felajánlotta az ENSZ-nek, hogy kifejezetten a szomáliai segélyek biztosítására többnemzetiségü humanitárius missziót szervezne. Az ENSZ kapott az alkalmon, a BT pedig felhatalmazta a létrejövő UNITAF-ot (Unified Task Force), hogy „minden szükséges eszközt” (by all necessary means) vessen be, hogy a segélyszállítmányok eljussanak rendeltetési helyükre. (S/RES/794 [1992]) A 24 ország katonáiból álló 37000 fös UNITAF év végére teljesítette vállalt feladatát, (Phillip [2005] p. 536.) miközben az UNOSOM is a térségben maradt, és a két intézmény között - főként a tevékenységükben mutatkozó átfedések és az eltérő mandátumok miatt - nem volt konfliktusmentes a kapcsolat.

1993 elején az ENSZ úgy döntött, hogy tekintettel arra, hogy az UNOSOM nem sok eredményt tudott felmutatni a szomáliai helyzet megoldása terén, új missziót hív életre, felváltva ezzel nemcsak a később UNOSOM I.-nek nevezett UNOSOM-ot, hanem az UNITAF-ot is. ${ }^{45} 1993$ márciusában a 814-es számú BT határozattal hozta létre az UNOSOM II.-t, amely kibővített mandátummal és jelentősen megnövelt létszámmal kezdte meg müködését. (S/RES/814 [1993]) A kibővített mandátum értelmében az UNOSOM II. már jogosult volt céljai elérése érdekében a fegyverhasználatra, erre korábban az UNOSOM I. esetében csak önvédelmi célból volt lehetőség. Az UNOSOM II. feladatai közé tartozott a humanitárius segélyszállítmányok biztosítása, valamint a gazdasági, társadalmi és politikai újjáépítéshez való hozzájárulás; a 22000 fös kontingens tevékenysége pedig az egész országra kiterjedt. (UN Peacekeeping

\footnotetext{
${ }^{45}$ Az UNITAF 1993. május 4-én vonult ki Szomáliából.
} 
Operations - UNOSOM II. [é. n.]) Az UNOSOM II. sem tudott azonban véget vetni az anarchikus állapotoknak és képtelen volt a harcban álló feleket megegyezésre bírni, mindeközben pedig egyre veszélyesebb (és egyre ellenségesebb) környezetnek bizonyult Szomália a békefenntartók számára: a misszió müködése alatt 154 kéksisakos vesztette életét. Az ENSZ végül 1994 novemberében az UNOSOM II. mandátumának 1995. márciusi megszüntetéséröl döntött. (S/RES/954 [1994])

Az UNOSOM nemcsak a területi adminisztrációk vizsgálatánál tartogat számunkra mondanivalót, hanem a békefenntartás történetében is mérföldkőnek számít, ahol az ún. harmadik generációs békefenntartás kezdetét éppen a szomáliai ENSZszerepvállaláshoz kötik. Itt derült ki ugyanis, hogy az elsősorban békefenntartó funkció ellátásán alapuló mandátum elégtelennek bizonyul a megváltozott nemzetközi körülmények ${ }^{46}$ között, ezzel ugyanis eredményt elérni szinte lehetetlen (erre bizonyíték az UNOSOM I.). A kilencvenes évektől jellemző (poszthidegháborús) megváltozott környezet jellemző vonásai az alábbiakban foglalhatók össze: nem államok közti, hanem államon belüli konfliktusok a jellemzőek; a békefenntartók nem a válságok lezárulása után, hanem még a válságok alatt érkeznek az adott térségbe; a polgárháborús viszonyok között gyakran nem világos, hogy melyik fél az államhatalom birtokosa, ezért a consent fogalma sokszor értelmezhetetlen; a környezet veszélyes, időnként kifejezetten ellenséges a nemzetközi szervezetek jelen levő alkalmazottaival szemben. Az imént sorolt karakterisztikák mindegyike jellemző a szomáliai esetre, mérföldkő jellege így igazolható és érthető. Jelentős tanulság a szomáliai precedensből még, hogy sokkal inkább előtérbe helyeződik a poszthidegháborús időszak válságainál a békefenntartásnak a békekikényszerítési aspektusa (lásd az UNOSOM II. bővülö mandátumát a fegyverhasználat terén). Szintén jelentős változás, hogy a korábbi klasszikus, alapvetően biztonsági jellegü szerepvállaláson túl (biztonságos környezet megteremtése, felek szétválasztása, tüzszünet betartásának ellenőrzése stb.) a nemzetközi jelenlétnek sokkal inkább multidimenzionálisnak kell lennie, s fel kell vállalnia egyéb - megbékélés előmozdítása, aknaszedés, vagy humanitárius, politikai, jogi, gazdasági feladatok stb. - elvégzését is. A nemzetközi területi adminisztrációk is ennek következtében válnak egyre komplexebbekké, s terjed ki tevékenységük egyre

\footnotetext{
${ }^{46}$ A témáról 1d. bővebben többek között: Prandler Árpád (szerk.) (2011): Nemzetközi szervezetek és intézmények. Aula Kiadó, Budapest, pp. 185-192.
} 
több területre a kilencvenes évektől. A szomáliai nemzetközi szerepvállalás során például elsőként vállalt fel az UNOSOM II. humanitárius feladatokat. A misszió jelentőségét nem a sikerei adják (hiszen összességében inkább sikertelennek tekinthető), hanem mindazon tanulságok, amelyekkel a békefenntartás és a területi igazgatás vizsgálata számára szolgált.

\subsubsection{Bosznia-Hercegovina}

A nemzetközi területi igazgatásra több példát is említhetünk a Balkánon, így BoszniaHercegovinát - s azon belül külön is Mostart és Brčkót -, valamint Koszovót. Boszniával és Koszovóval ehelyütt azonban csak röviden foglalkozunk, éppen csak annyira, amennyire a történeti áttekintés során szükséges, hiszen mindkettőt részletesen megvizsgáljuk a dolgozat későbbi fejezeteiben, s az e részeknél említett intézményeket is részletesen bemutatjuk.

A jugoszláv dezintegrációs folyamatot kísérő délszláv válság 1995 októberében véget ért, december 14-én Párizsban pedig aláírták a daytoni megállapodást. A békemegállapodás a háború utáni rendezés legfőbb dokumentuma, mert 11 melléklete részletesen szabályozta a háború utáni helyzetet, különösen a háború által leginkább sújtott Bosznia-Hercegovina felépítését és működését, s az ország három államalkotó nemzetének (bosnyákok, szerbek és horvátok) az állam irányításában való részvételét. A megállapodás rögzítette továbbá az állam közigazgatási felosztását, a szövetségi (Bosznia-Hercegovina) és az entitás (Bosznia-hercegovinai Föderáció és Republika Srpska) szintü legalapvetőbb politikai intézményeket, valamint részletesen kitért a nemzetközi jelenlétre is.

A nemzetközi civil igazgatás egyik intézménye az 1995 decemberében létrehozott és 2002 decemberéig müködő UNMIBH (United Nations Mission in Bosnia and Herzegovina), amelynek legfőbb feladata a rendőrségi és igazságszolgáltatási reformok segítése, vezetője pedig az ENSZ főtitkárának különleges megbízottja (Special Representative of the Secretary-General and Coordinator of United Nations Operations in Bosnia and Herzegovina - SRSG). Az UNMIBH része volt 2002-ig az ENSZ rendőri alakulata, vagyis az IPTF (United Nations International Police Task Force), ennek helyébe lépett az Európai Unió Rendőri Missziója (European Union Police Mission - 
EUPM). Az UNMIBH az imént említett feladatokon túl az ENSZ egyéb, helyszínen zajló intézményeit és azok tevékenységét is ellenőrizte, úgymint a gazdasági segélyezés, az infrastruktúra helyreállítása, a menekültek visszatérése, az aknaszedés, a választások, az emberi jogok érvényesülése stb. (UN Peacekeeping Operations - UNMIBH [é. n.])

A nemzetközi adminisztráció polgári komponensének központi intézménye a nemzetközi közösség fömegbízottja és annak hivatala (Office of the High Representative in Bosnia and Herzegovina - OHR), ${ }^{47}$ valamint a Békevégrehajtó Tanács (Peace Implementation Council - PIC). A főmegbízott a legfőbb felelőse a daytoni szerződés polgári rendelkezései végrehajtásának, s 2002 és 2011 között a nemzetközi közösség főképviselője egyben az Európai Unió különleges bosznia-hercegovinai képviselője ${ }^{48}$ is volt. (Oellers-Frahm [2005] p. 207.) A civil igazgatásban több más nemzetközi szervezet (pl. EBESZ) is részt vett, az első években az átfedésekből és a hierarchikus viszonyok szabályozási hiányosságaiból több probléma is fakadt. Erre reagálva 1997ben született döntés arról, az OHR-é a végső szó a vitás kérdésekben. (Bíró [é. n.] 6. o.)

A nemzetközi igazgatás biztonsági aspektusának legfőbb letéteményese az ENSZfelhatalmazással, békefenntartóként a helyszínen tartózkodó eleinte NATO- (IFOR, SFOR), majd később EU-hadtest (EUFOR Althea), ${ }^{49}$ amely a békemegállapodás katonai rendelkezéseinek végrehajtását ellenőrzi.

Bosznia-Hercegovina két leginkább megosztott városa különleges irányítás alá került. A zömmel bosnyák-horvát vegyes lakosságú ${ }^{50}$ közép-boszniai Mostar (ahol a délszláv válság idején elkeseredett harc dúlt a bosnyákok és a boszniai horvátok között) 1994 júliusában EU-irányítás alá került (European Union Administration of Mostar EUAM). 1997 januárjában megnyílt az OHR regionális irodája a városban, amely az EUAM helyébe lépett. A másik nemzetközi irányítás alá vett város az észak-boszniai (a

\footnotetext{
${ }^{47}$ A rövidítéssel a személyre és a hivatalra is utalunk.

${ }^{48}$ European Union Special Representative - EUSR

49 IFOR (Implementation Force): 1995 decemberétöl 1996 decemberéig Bosznia-Hercegovinában müködő békefenntartó misszió, amelynek kötelékében ENSZ-felhatalmazással NATO- (és kis számban nem NATO-) tagállamok tevékenykedtek. Az IFOR-t 1996 decemberében a hasonló jellemzőkkel bíró SFOR (Stabilization Force) váltotta, amelytől a békefenntartói feladatokat 2004-től a zömmel EU által delegált EUFOR (European Force) Althea vett át.

${ }^{50}$ Mostar lakosságának kb. 3/4-e bosnyák és horvát (fele-fele arányban), 20\%-a pedig szerb. Az 1991-es népszámlálás szerint a bosnyákok, horvátok és szerbek aránya 35\%, 34\% és 19\% volt. (Popis stanovništva, domaćinstava, stanova i poljoprivrednih gazdinstava [1991] p. 17.)
} 
horvát határ mellett fekvő) Brčko, amely ugyan többségében bosnyákok által lakott, ${ }^{51}$ jelentőségét azonban nem lakosságának etnikai összetétele, hanem sokkal inkább földrajzi elhelyezkedése adja. A város ugyanis az entitások határán, az ún. posavinai folyosón helyezkedik el, azon a néhány kilométeres földsávon, amely a Republika Srpska északi és keleti fele közötti összeköttetést és folytonosságot biztosítja, ugyanakkor az egyetlen kijáratot jelenti az országból a Föderáció számára észak felé, éppen ezért birtoklása a délszláv válság alatt is kulcsfontosságú volt. A daytoni megállapodás külön rendelkezik Brčkóról, miszerint az ún. Brčkói Körzet területileg mindkét entitáshoz tartozik (a körzet egyik fele a Föderációban, másik a Republika Srpskában van, maga a város az utóbbiban), nem áll azonban egyik irányítása alatt sem, hanem az OHR által kinevezett és kiterjedt jogkörökkel rendelkező Felügyelö (Supervisor) irányítja. A nemzetközi igazgatás célja a menekültek visszatérésének és a város multietnikus jellegének biztosítása. Brčko széleskörű önállósággal és önkormányzatisággal rendelkezik, gyakorlatilag Bosznia harmadik entitásaként értelmezhető. (Chesterman [2004] p. 78.) Bár Brčkóra általában a sikeres nemzetközi igazgatás példájaként szoktak utalni, az igazság azonban az, hogy sem Mostarban, sem pedig Brčkóban nem sikerült felszámolni a megosztottságot. ${ }^{52}$

\subsubsection{Kelet-Szlavónia, Baranya és Nyugat-Szerémség}

A délszláv válság egyik kulcsmomentuma volt, amikor a többségében szerbek lakta horvátországi Krajinában, Kelet- és Nyugat-Szlavóniában, valamint Baranyában 1991ben a helyi szerbek a Jugoszláv Néphadsereg hathatós támogatásával kinyilvánították az ún. Krajinai Szerb Köztársaság elszakadását Horvátországtól. Ezután ugyanis ezeket a részeket egészen a háború végéig a szerbek tartották ellenőrzésük alatt, miközben nagy számban menekültek el innen a nem szerb nemzetiségüek. 1995 májusában és augusztusában a Vihar és Villám hadműveletek keretében Horvátország visszaállította területi integritását és visszaszerezte a szerbektől egyharmadnyi szakadár államterületét - Kelet-Szlavónia, Baranya és a Nyugat-Szerémség kivételével, amelyek visszafoglalásáról nemzetközi nyomásra mondott le. 1995 novemberében az erduti

\footnotetext{
${ }^{51}$ Brčko lakossága az utolsó, 1991-es népszámlálás szerint 87627 fő volt, ennek 44\%-a bosnyák, 25\%-a horvát, 21\%-a pedig szerb. (Popis stanovništva, domaćinstava, stanova i poljoprivrednih gazdinstava [1991] p. 16.)

${ }^{2}$ A témáról lásd bővebben az International Crisis Group anyagait: Bosnia: A Test of Political Maturity in Mostar. ICG, Europe Briefing N54, 27 Jul 2009; és Brčko Unsupervised. ICG, Europe Briefing Nº6, 8 Dec 2011.
} 
megállapodásban ${ }^{53}$ a horvátok megegyeztek a helyi szerbekkel, hogy Kelet-Szlavóniát átmenetileg nemzetközi igazgatás alá helyezik. A megállapodás értelmében a Biztonsági Tanács 1996 januárjában az 1037. számú határozatával létrehozta az UNTAES-t (United Nations Transitional Administration for Eastern Slavonia, Baranja, and Western Sirmium), (S/RES/1037 [1996]) vezetőjének különleges megbízottat nevezett ki az amerikai Jacques Paul Klein személyében, a misszió központját pedig a délszláv háború kezdeti szakasza egyik legszörnyübb vérengzésének helyszínére, (Chesterman [2004] p. 71.) Vukovárba helyezték.

A 30 ország 2800 fős katonai és civil képviselőiből álló UNTAES-nek polgári és katonai feladatai is voltak, előbbiek közé a közigazgatás müködtetését, a közszolgáltatások biztosítását, a rendőri erők felállítását, a választások megszervezését, a terület gazdaságfejlesztési programjának meghatározását és a menekültek visszatérésének elősegítését sorolhatjuk. A biztonsági komponens részeként pedig a misszió feladata volt a rendfenntartáson túl a leszerelés ellenőrzése, a menekültek és belső menekültek biztonságos visszatérésének biztosítása az ENSZ Menekültügyi Főbiztosságával (UNHCR) együttmüködésben, valamint általánosságban az erduti megállapodás rendelkezései érvényre juttatásának előmozdítása. (UN Peacekeeping Operations - UNTAES [é. n.])

A misszió sikeresnek tekinthető, hiszen a leszerelést a vállalt határidőre befejezték (1996. június 20-ra), az átmeneti rendőri erőket megszervezték, az 1997 áprilisában tartott választások pedig incidens nélkül zajlottak. A siker titka minden valószínüség szerint a jól definiált és kellően szúkre szabott mandátumban, a felek kompromisszumkészségét szilárdan megalapozó egyezményben, valamint a hiteles szankcionálási potenciállal felvértezett egységes és erőskezü nemzetközi irányításban rejlett. Az egyetlen kevésbé sikeres terület a menekültek mérsékelt visszatérése volt, ez azonban jóval komplexebb kérdés annál, semhogy csupán az UNTAES sikertelenségeként értékeljük. A misszió 1998. január 15-én beteljesítette mandátumát és megszünt, helyére 180 fös civil kontingens érkezett maximum kilenc hónapos időtartamra a rendőrségi reformok ellenőrzésére. (Chesterman [2004] p. 71.)

\footnotetext{
${ }^{53}$ Basic Agreement on The Region of Eastern Slavonia, Baranja, And Western Sirmium.
} 


\subsubsection{Kelet-Timor}

A portugál gyarmatosítók a 16. században jelentek meg Timorban, a 19. században pedig a térségben szintén jelen levő Hollandiával megállapodtak, hogy Nyugat-Timor a hollandoké, Kelet-Timor pedig a portugáloké lesz. 1960-ban, amikor Indonézia elnyerte függetlenségét Hollandiától, a nyugat-timori részt az indonéz államterület részévé nyilvánították, a keleti rész pedig portugál uralom alatt maradt. 1955-ben Portugália felvételt nyert az ENSZ-be. A világszervezet nyomására 1960-ban a portugál uralom alatt álló területek - köztük Kelet-Timor is - önkormányzatisággal nem rendelkező terület lett, (A/RES/1542(XV) [1960]) amely felett az irányító hatalom szerepét továbbra is a portugál állam látta el. (Benzing [2005] p. 300.)

A függetlenség opciója a dekolonizációs folyamatban kissé megkésetten, csak 1974-ben merült fel Kelet-Timor számára, amikor a Portugáliában lezajlott puccs következtében hatalomra kerülö rezsim - elödjével ellentétben - támogatta a korábbi gyarmatok autonómiájának kibővítését. A formálódó kelet-timori politikai erők azonban megosztottak voltak a terület jövőjét illetően: némelyik a függetlenséget támogatta, volt, amelyik az Indonéziával való egyesülést pártolta, mások pedig a Portugáliával való államjogi kötelékek fenntartásáért szálltak síkra. A belső viszályok hamarosan polgárháborúba sodorták a területet, végül a győztes függetlenségpárti politikai erő, a Falintil $^{54} 1975$ novemberében kikiáltotta a Kelet-timori Demokratikus Köztársaságot. A vesztes UDT ${ }^{55}$ ekkor Indonéziához fordult segítségért, amely válaszképpen 1975. december 7-én megszállta Kelet-Timort. A nemzetközi közösség nagy része elítélte az indonéz lépést, s hasonló szellemiségben az ENSZ Közgyülése és a Biztonsági Tanács is foglalkozott néhány határozat erejéig ${ }^{56}$ a kelet-timori kérdéssel, a kérdés azonban valószínűleg köszönhetően Indonézia nemzetközi rendszerben betöltött stratégiai fontosságának - lényegében két évtizedre lekerült a napirendről. 1976 nyarán Indonézia a területet 27. tartományává nyilvánította, miközben az ENSZ továbbra is portugál irányítás alatt álló, önkormányzattal nem rendelkező területként kezelte azt.

\footnotetext{
${ }^{54}$ Falintil (Forças Armadas de Liberatação Nationalde Timor Leste): Forradalmi Front a független KeletTimorért.

${ }^{55}$ UDT (União Democrática Timorense): Timori Demokratikus Unió.

${ }^{56}$ Vö. A/RES/3485 (XXX) of 12 December 1975, S/RES/384 (1975) of 22 December 1975, S/RES/389 (1976) of 22 April 1976.
} 
A kelet-timoriak a Falintil vezetésével mindeközben folytatták a kezdetben fegyveres, majd a nyolcvanas évektől inkább a passzív ellenállásban megnyilvánuló ellenállásukat az indonéz megszálló hatalom ellen. A térség akkor került ismét a nemzetközi érdeklődés homlokterébe, amikor 1991 novemberében a santa cruzi mészárlásban az indonéz erők 270 fegyvertelen tüntetőt öltek meg, amikor a tömegbe lőttek. (Benzing [2005] pp. 300-303.) Az áttörésre azonban 1997-ig, az indonéz elnök Suharto haláláig várni kellett, ugyanis utódja, Habibie volt az, aki hajlandó volt napirendre venni a kelettimori ügyet. 1999. május 5-én az ENSZ gyámkodása mellett szerződésben ${ }^{57}$ állapodott meg Indonézia és Portugália, hogy a világszervezete felügyelete mellett a kelet-timori nép referendumon (popular consultation) nyilváníthatja ki akaratát a terület státuszát illetően, s eldöntheti, hogy Kelet-Timor Indonézián belül élvezzen-e „speciális autonómiát”, vagy legyen független. 1999. augusztus 8-ra tüzték ki a népszavazást, amelynek felügyeletével a BT 1246. sz. határozatával létrehozott UNAMET-et (United Nations Mission in East Timor) bízták meg. (S/RES/1246 [1999]) A referendumot azonban el kellett halasztani augusztus végére, mert az idérkező UNAMET azzal szembesült, hogy a körülmények nem alkalmasak a szabad választás megtartására, az Indonéz-párti milíciák ugyanis megfélemlítették a függetlenségpárti lakosokat, $\mathrm{s}$ sokukat meg is öltek. Némiképp érthetetlen volt, hogy a kelet-timori biztonságos környezet biztosítása miért lett a megállapodások értelmében az indonéz erőszakszervezetek feladata, amelyek sokáig láthatóan nem kívántak érdemben fellépni a jogsértő milíciákkal szemben, de elutasították a nemzetközi biztonsági erők behívását. A népszavazásra végül 1999. augusztus 30-án sor került, a részvétel 98\%-os volt, s a szavazók 78\%-a támogatta a függetlenséget. (Fox [2008] p. 99.) A népszavazást követően újra fellángolt az erőszak és a milíciák még kegyetlenebb hadjáratot indítottak a kelet-timori lakosság ellen, az indonéziai hivatalos erők pedig továbbra sem tudtak és nem is akartak tenni semmit ennek megfékezésére. Az UNAMET evakuálta alkalmazottait és hozzátartozóikat Ausztráliába, a kelet-timori lakosok százezrei pedig vagy Nyugat-Timorban vagy más országokban kerestek menedéket. (UN Peacekeeping Operations - UNTAET [é. n.]) A nemzetközi közösség erőteljes nyomást gyakorolt az indonéz kormányra: az APEC ${ }^{58}$ politikai és gazdasági szankciókat helyezett kilátásba,

\footnotetext{
${ }^{57}$ Agreement between the Republic of Indonesia and the Portuguese Republic on the question of East Timor. Annex I to the Report of the Secretary-General on the Question of East Timor. (A/53/951$\mathrm{S} / 1999 / 513$ [1999])

${ }_{58}$ Ázsiai és Csendes-óceáni Gazdasági Együttmüködés (Asia-Pacific Economic Cooperation - APEC):

21 tagot számláló, 1989-ben létrejött regionális nemzetközi szervezet. (http://www.apec.org/)
} 
(Chesterman [2004] p. 63) az amerikai elnök az IMF-segélyek visszafogásával fenyegetett (ne feledjük, ekkoriban zajlott a súlyos távol-keleti pénzügyi válság), a Világbank elnöke személyesen írt levelet az elnöknek, Portugália heves kirohanásokat intézett az ENSZ fórumain Indonézia ellen, Brazília pedig egyenesen arra célzott, hogy vannak államok, amelyek készek fegyveres is beavatkozni Kelet-Timorban. (Fox [2008] p. 101.) Indonézia végül meghátrált és megadta jóváhagyását (consent) a nemzetközi békefenntartók Kelet-Timorba telepítéséhez. Az INTERFET-et (International Force in East Timor) 1999 szeptemberébe az 1264-es számú ENSZ BT határozat hozta létre, (S/RES/1264 [1999]) a 9150 katonából és 1540 polgári alkalmazottból álló misszió vezetését Ausztrália vállalta magára. (Igaz [2004] p. 19.) A nemzetközi erők megérkezését követően az indonéziai katonaság és a közigazgatásban dolgozó indonéz állami alkalmazottak elhagyták Kelet-Timort, az UNAMET pedig visszatelepült a fővárosba, Dilibe, s hozzáfogott a legégetőbb feladat ellátásához: a nélkülöző lakosság számára a segélyszállítmányok megszervezéséhez. 1999. október 19-én Indonézia parlamentje, a Népi Tanácskozó Gyülés elismerte a kelet-timori referendum eredményét, az ENSZ pedig a megváltozott körülmények miatt 1999 októberében új missziót, állított fel, az UNTAET-et (United Nations Transitional Administration in East Timor). (S/RES/1272 [1999])

Az UNTAET mandátuma sokban hasonlított a koszovói UNMIK-éhoz, feladatai a következők voltak: a közigazgatási rendszer kiépítése, a biztonságos körülmények és a közrend garantálása, a menekültek visszatérésének segítése, a közszolgáltatások biztosítása, a humanitárius segítségnyújtás koordinálása, fejlesztés és rehabilitáció. Az UNTAET civil komponensének része volt a több, mint másfélezer fös nemzetközi rendőri erő, katonai komponense pedig az INTERFET-et váltotta fel. Az UNTAET müködése alatt fokozatosan kiépültek a kelet-timori demokratikus intézmények, parlamenti és elnökválasztásokat tartottak, megalakult a parlament és a kormány. Az UNTAET küldetése véget ért 2002 májusában, Kelet-Timor pedig 2002. szeptember 27én az ENSZ 191. tagállama lett. A nemzetközi közösség mindazonáltal nem hagyta magára az új államot, az UNTAET-et felváltó új misszióról döntött 2002 májusában, (S/RES/1410 [2002]) ez volt az UNMISET (United Nations Mission of Support in East Timor), amely a kelet-timori intézményeket támogatta a stabilitás megteremtésében, a demokrácia és a jog uralma kiépítésében, az intézményi kapacitás fejlesztésében, a belső és külső biztonság garantálásában és a határellenőrzésben. Az UNMISET 
fokozatosan átadta összes jogosítványát a helyi eröknek, mandátuma 2005 májusában járt le, helyébe pedig a rövid ideig, 2006 augusztusáig müködő UNOTIL lépett (United Nations Office in Timor-Leste). (S/RES/1599 [2005]) Ennek mandátuma szintén különbözött az előző missziókétól, amennyiben már csupán a tanácsadás volt a fő profilja a közigazgatás, a jó kormányzás, a rendőrségi reformok, a határellenőrzés és az emberi jogok területén, állománya 120 szakértőből állt. (UN Peacekeeping Operations UNMISET [é. n.]) Az UNOTIL-t a ma is müködő UNMIT (United Nations Integrated Mission in Timor-Leste) váltotta ismét eltérő mandátummal, (S/RES/1704 [2006]) amiben nagy szerepe volt annak, hogy 2005 tavaszán-nyarán a komplex politikai és társadalmi feszültségek következményeként újra zavargások támadtak a térség legszegényebbnek tartott fiatal országában. Az UNMIT 1600 nemzetközi rendőrből, valamint katonai összekötő tisztekből és civil alkalmazottakból tevődött össze, mandátuma pedig az alábbiakra terjedt ki: a stabilitás megteremtése érdekében a kormány és az állami intézmények támogatása, a demokratikus kormányzás kultúrájának megteremtése, a politikai dialógus előmozdítása, a 2007-es parlamenti és elnökválasztások megszervezésében és lebonyolításában segítségnyújtás, az emberi jogok garantálása, a válságot követő újjáépítésben és fejlesztésben az ENSZ más szerveivel való együttműködés és koordináció. Később a mandátumot - miután 2008 elején ismét kiújult az ellenségeskedés, s magát az elnököt is támadás érte - tovább bővítették az alábbi területekkel: az igazságszolgáltatási szektor reformjának és az intézményi kapacitásépítési folyamatnak a felgyorsítása, a közrend fenntartásában elsőrendű fontosságú kelet-timori rendőrség (Policia Nacional de Timor-Leste - PNTL) további fejlesztése. Az UNMIT jelentős szerepet kapott a 2010-es helyhatósági választások megszervezésében és lebonyolításában is, s ugyanezt kérte a kelet-timori politikai vezetés a 2012-es parlamenti és elnökválasztásokon is.

A kelet-timori területi adminisztráció a szakirodalomban az egyik leginkább tárgyalt a nemzetközi igazgatási példák sorában - az UNTAES és a későbbiekben tárgyalt UNMIK mellett -, s ez a számos, egymást követő kelet-timori misszió közül elsősorban az UNTAET-re vonatkozik, amelynek idején az ENSZ a kelet-timori terület feletti igazgatást teljes mértékben átvette. Valóban sok hasonlóság van az említett missziók között (s az UNTAET esetében a koszovói „minta” másolása is meglehetősen egyértelmü, s kézenfekvő is), több vonatkozásban azonban a területi adminisztrációk speciális esetét képviseli az UNTAET. Az egyik sajátosság, hogy a kelet-timori példa a 
késői dekolonizáció tipikus esete, a kettős megkésettség oka pedig az, hogy az eleve csak a hetvenes évek közepén napirendre került Portugáliától való függetlenedés megvalósulását az azonnali indonéz megszállás még hosszú ideig gátolta. A másik sajátos vonása a kelet-timori esetnek, hogy az ENSZ a leginkább radikális államépítő szerepre Kelet-Timor esetében vállalkozott, ${ }^{59}$ (Benzing [2005] pp. 297-298.) olyan környezetben ráadásul (s nevezhetjük ezt a harmadik sajátosságnak), ahol nem voltak az önkormányzatiságnak egyáltalán semmiféle hagyományai. Szintén speciálisnak tekinthető Kelet-Timor abban a vonatkozásban, hogy viszonylag problémamentes környezetben végezte az ENSZ az államépítő tevékenységét, amennyiben a kis területü Kelet-Timorban nem kellett számolni a társadalmat megosztó etnikai ellentétekkel; (Traub [2000] p.75-81.) és világos volt az is, hogy a végcél a teljes függetlenség és az önkormányzásra képes állam kiépítése, s mind a helyi lakosság, mind pedig a politikai vezetés egyöntetűen támogatta a nemzetközi szerepvállalást. Fontos különbség továbbá Koszovóval szemben az is, hogy a beavatkozó nemzetközi szervezetek és államok között nem volt jelen az a megosztottság, ami a balkáni missziók esetében egyértelműen tapasztalható a helyzetértékelés és a feladat-meghatározás eltérő interpretációi nyomán. (Chesterman [2004] p. 60) Szintén egyéni karakterisztika, ahogy az egymást követő kelet-timori ENSZ-missziók igyekeztek alkalmazkodni a megváltozott körülményekhez és az akut kérdéseket előtérbe helyezni az újabb és újabb mandátumok meghatározásakor. Felróható persze az ENSZ-adminisztrációnak, hogy ezek az adaptációs ingerek általában kissé megkésetten jelentkeznek, de ne feledkezzünk meg arról, hogy a nemzetközi területi igazgatás úttörö példája a kelet-timori eset.

\subsubsection{Sierra Leone}

A nyugat-afrikai Sierra Leonét az angolok a 18. és 19. század elején szerezték meg, s irányították egészen az ország 1961-es függetlenségéig. Sierra Leonében 1991-ben véres polgárháború tört ki a szomszédos Libéria által támogatott lázadó erők, a Foday Sankoh vezette Forradalmi Egységfront (Revolutionary United Front - RUF) és a

\footnotetext{
${ }^{59}$ Az ENSZ ezen szerepvállalása egyfelől összecseng Boutros Boutros-Ghalinak, az ENSZ főtitkárának 1992-es Békeprogramjával (An Agenda for Peace), amely a világszervezet helyének és szerepének újradefiniálására tesz kísérletet a poszthidegháborús időkben, másfelől nem tükrözi azt a szkepticizmust, amit a 2000-es Brahimi-jelentésböl olvashatunk ki, ahol az ENSZ algériai nagykövete óva inti az ENSZet attól, hogy a klasszikus, első generációs békefenntartáson túl magára vállaljon olyan feladatokat, amelyeket aztán nem lesz képes teljesíteni egyszerüen azért, mert nem alkalmas rá.
} 
kormányerők között. ${ }^{60} \mathrm{Az}$ ország irányítása a polgárháború alatt többször is cserélődött a gyakori puccsok következtében. 1995 májusában a lázadók már a fővárost, Freetownt fenyegették, ekkor az ország vezetése felfogadta a dél-afrikai Executive Outcomes cég fizetett zsoldosokból álló seregét, amely lényegében egy hónap alatt visszaverte a RUFot és visszaállította a kormány ellenőrzését a gyémántbányák felett is. (Keen [2005] pp. 151-152.) 1996. november 30-án megkötötték az abidjani fegyverszüneti egyezményt, Elefántcsontpart, az Afrikai Egységszervezet, az ENSZ és a Brit Nemzetközösség közvetítésével. A dél-afrikai zsoldosok kivonása után azonban egyre inkább elharapódzott ismét az erőszak, 1997 májusában pedig egy újabb puccsal hatalomra került erők kiegyeztek a RUF-fal, amelynek fontos pozíciókat jutattak az állami vezetésben. Az ECOWAS ${ }^{61}$ döntő lépésre szánta el magát, s 1997. júniusban és 1998. februárban a Nigéria-vezette ECOMOG-ot (Economic Community of West African States Monitoring Group) küldte Sierra Leonéba, hogy helyreállítsa a rendet. ${ }^{62}$ $\mathrm{Az}$ ECOMOG végül márciusra visszaszorította a RUF erőit. (Goldmann [2005] pp. 460-463.)

1998 júliusában az ENSZ BT felhatalmazásával érkezett Sierra Leonéba az UNOMSIL (United Nations Observer Mission in Sierra Leone) azzal a mandátummal, hogy ellenőrizze a békét és a leszerelési folyamatot. (S/RES/1181 [1998]) Az UNOMSIL azonban feladatát nem tudta beteljesíteni, mert a harcok ismét fellángoltak. Mivel sem az ECOMOG, sem pedig az ENSZ nem szeretett volna túlzottan bevonódni a sierra leonei válságba, ezért a nemzetközi közösség elkezdte szorgalmazni a felek közti megegyezést a hatalommegosztásról. Ennek a folyamatnak az eredménye volt az loméi megállapodás, ${ }^{63}$ amelyben az érintettek többek között abban is megállapodtak, hogy

\footnotetext{
${ }^{60}$ A RUF-nak nem voltak elérendő politikai céljaik, sem ideológiájuk, a polgárháború nem is etnikai vagy vallási választóvonalak mentén zajlott. A nyilvánvaló mozgatóerő a RUF számára a Sierra Leone gyémántban gazdag területei feletti ellenörzés megszerzése volt. A „véres gyémántok” Libériába kerültek, amely Charles Taylor elnök vezetésével jelentős bevételeket szerzett azok értékesítéséböl, ezért érdekében állt a RUF támogatása.

${ }^{61}$ Nyugat-afrikai Államok Gazdasági Közössége (Economic Community of West African States ECOWAS; Communauté économique des États de l'Afrique de l'Ouest - CEDEAO): 1975-ben létrejött regionális gazdasági tömörülés, 15 tagállama van, a nigériai Abudjában székel. (http://www.ecowas.int/) ${ }^{62}$ A beavatkozás legitim jellege kérdéses, ugyanis ENSZ BT felhatalmazás nélkül indították útjára a missziót. Az ECOWAS sem hatalmazta fel az akcióra Nigériát, de ez valójában irreleváns abból a szempontból, hogy erőszak ilyen módon történő alkalmazására a nemzetközi jog jelenleg érvényes szabályai szerint csak BT felhatalmazás birtokában lehetséges, s a felhatalmazásnak explicitnek és elözetesnek kell lennie. Az utólagos felhatalmazásról ld. Simma, Bruno et al. (2002): A Charter of the United Nations. A Commentary. Oxford University Press, idézi Goldmann (2005) pp. 470-471.

${ }^{63}$ A megállapodás teljes szövegét lásd: Peace Agreement Between the Government of Sierra Leone and the Revolutionary United Front of Sierra Leone.
} 
Sankoh nemcsak az elnökhelyettesi pozíciót kapja meg, hanem a gyémántbányászatot irányító tárcát is. Hamarosan kiderült azonban, hogy Sankoh nem kívánja betartani a loméi megállapodásban foglaltakat és pozícióját használja fel arra, hogy továbbra is irányíthassa az illegális gyémántkereskedelmet.

Az ENSZ 1999 októberében úgy határozott, hogy egy nagyobb létszámú és kiterjedtebb mandátumú békefenntartó kontingenst vezényel az országba, ez volt az UNAMSIL (United Nations Mission in Sierra Leone). (S/RES/1270 [1999]) A békefenntartók feladata lett volna a civilek védelme, azonban nem sikerült a rendet helyreállítania, sőt, többször a RUF támadásainak céltáblája volt az UNAMSIL, s egy alkalommal 500 kéksisakost ejtettek túszul a felkelők. Az ENSZ erre reagálva megemelte a kontingens létszámát 13 ezerre, majd 17 ezerre, s újabb feladatokkal bízta meg, mint például a kormányépületek, repülőterek és fontosabb közlekedési csomópontok biztosítása, és az igazságszolgáltatásért felelős szervek segítése. (Chesterman [2004] pp. 86-87.) A helyzet konszolidálásának kulcsa valószínűleg egyrészt abban rejlett, hogy a kezdeti korlátozott fegyverhasználat helyett a BT felhatalmazta az UNAMSIL-t, hogy az ellenséges akciókra „erőteljes” ellentámadással feleljen, másrészt pedig abban, hogy az UNAMSIL-t 2000-ben a sierra leonei hadseregen túl brit intervenciós erők is támogatták, s együtt végül sikerrel visszaszorították a RUF-seregeket. Az abujai tüzszüneti megállapodás megkötését követően több intézkedést is hoztak, amivel megpróbálták megakadályozni Libéria és a RUF kapcsolatfelvételét, s így az utóbbit igyekeztek meggyengíteni. Sierra Leonében létrehozták a súlyos humanitárius jogsértéseket elkövetők megbüntetésére a helyi büntetőtörvényszéket, amelynek vádlottai közé került Sankoh is. 2002-ben elnöki, 2004-ben pedig helyhatósági választásokat tartottak az UNAMSIL közremüködésével, amelynek mandátuma végül 2005 decemberében járt le (Goldmann [2005] pp. 464-465.)

Az UNAMSIL-ra minden valószínűség szerint a békefenntartás sikertelen missziójaként fognak utalni, ami több tényezőre vezethető vissza. A legfontosabb ezek közül minden bizonnyal az, hogy a misszió felkészületlennek mondható - Malone és Thakur egyenesen „drámaian rosszul felszerelt és hiányosan képzett csapatokról” beszél (Malone-Thakur [2001] p. 17.) -, ami nyilvánvalóan a nemzetközi közösség részérö1 jelentkező érdektelenségnek és a felelősségvállalás elkerülésének köszönhető. 


\subsubsection{Koszovó}

Amint arra a boszniai nemzetközi területi adminisztráció rövid leírásánál fentebb már utaltunk, a balkáni példák közül a koszovói UNMIK (United Nations Interim Administration Mission in Kosovo) is a dolgozat későbbi részében kerül bővebb kifejtésre, itt csak a legszükségesebb mértékben térünk ki bemutatására.

A kilencvenes évek második felére a délszláv térség talán legproblémásabb gócpontja, Koszovó is háborúba sodródott. A többségében albánok lakta szerbiai tartomány már a nyolcvanas évek óta kiterjedtebb autonómiát, később függetlenséget követelt magának, amire a belgrádi vezetés egyre keményebb fellépéssel reagált, végül a nyolcvanas évek végén teljesen visszavonta Koszovó autonómiáját. A koszovói albánok kezdetben passzív ellenállással és a hivatalos intézmények bojkottjával reagáltak, a kilencvenes évek közepére viszont megjelentek a radikálisabb erők is, melyek fegyveres úton kívánták céljaikat elérni. Az 1989-1999-es koszovói válságnak 1999 márciusa és júniusa között a NATO-beavatkozás vetett véget, a légi bombázás lezárulását rögtön követte a rendező dokumentum, az ENSZ BT 1244. számú határozatának ${ }^{64}$ elfogadása.

A BT határozat amellett, hogy lezárta a válságot, rendelkezett a tartományba telepített nemzetközi polgári és biztonsági jelenlétről. A civil igazgatás központi keretintézménye az UNMIK lett, amelynek koordináló szerepével igyekeztek harmonizálni a különböző nemzetközi szereplőknek (EU, EBESZ, nemzetközi pénzügyi szervezetek stb.) a stabilitás érdekében a térségben tett erőfeszítéseit. (UN Peacekeeping Operations UNMIK [é.n.]) A nemzetközi polgári igazgatási struktúra irányítója Koszovóban az ENSZ fő́titkárának koszovói különmegbízottja (Special Representative of the SecretaryGeneral for Kosovo - SRSG), akinek ma már feladatai közé tartozik az is, hogy a 2008tól Koszovóban tevékenykedő EULEX-szel együttmüködjön. Az EULEX (European Union Rule of Law Mission) eredetileg azért érkezett volna a térségbe, hogy az UNMIK helyébe lépjen, de utóbbi komplex területi igazgatást megvalósító mandátuma helyett jóval kevesebb végrehajtási jogosítvánnyal rendelkezve és szükebb területen lássa el feladatát. A koszovói szerbek és albánok, valamint Belgrád ellenállása és vitája a

${ }^{64}$ S/RES/1244 (1999) of 10 June 1999. Forrás: http://www.un.org/Docs/scres/1999/sc99.htm (letöltés: 2010.08.05.) 
nemzetközi adminisztráció struktúráját illetően megakadályozta a békés átmenet megvalósulását, így ma Koszovóban párhuzamosan müködik az UNMIK és az EULEX.

A nemzetközi biztonsági erőket az ENSZ-felhatalmazással rendelkező, de a NATO vezetése alatt álló KFOR (Kosovo Force) adja, amely azzal a céllal érkezett Koszovóba, hogy megakadályozza az ellenségeskedések kiújulását, garantálja a biztonságot, segítse a koszovói albánok fegyveres erejének leszerelését és munkáját a civil igazgatással együttmüködésben végezze. (Friedrich [2005] pp. 235-237.)

A koszovói igazgatási modell - hasonlóan a boszniaihoz - egy, a korábbi konfliktust lezáró nemzetközi dokumentum (ez esetben egy BT határozat) alapján kialakított struktúra alapján müködik. A rendező dokumentum azonban nem határozta meg a terület végleges státuszát, és ebből számos bonyodalom származott. A státuszhelyzet sajátos „rendezése” - amikor a koszovói parlament 2008 februárjában egyoldalúan deklarálta Koszovó függetlenségét Szerbiától - pedig jelentős feszültségeket okozott mind a regionális balkáni, mind pedig a szélesebb értelemben vett nemzetközi környezetben. A koszovói nemzetközi területi adminisztráció az eddigi legkomplexebb igazgatási misszió, amely számos tanulsággal szolgálhat a téma kapcsán, ezek kifejtésére a dolgozat későbbi részében térünk ki.

\subsubsection{Afganisztán}

Afganisztán újfajta tapasztalatokkal gazdagíthatja a nemzetközi területi igazgatással kapcsolatos szakirodalmat, számos tekintetben ugyanis speciálisnak tekinthető. Az egyik ilyen sajátosság - amely az afganisztáni és az iraki beavatkozásra is érvényes megállapítás -, hogy a terrorizmus ellen indított háború következményeként jelentek meg a nemzetközi erők az országban. (Chesterman [2004] p. 87.) A további sajátosságok Afganisztán történelmében és egyedi politikai-társadalmi hagyományaiban és felépítésében gyökereznek. Afganisztán azon kevés nem-európai államok közé tartozik, amelyeket klasszikus értelemben soha nem gyarmatosítottak. ${ }^{65}$

\footnotetext{
${ }^{65}$ Az afgán államiság eredete a 18. századig nyúlik vissza, ám a terület stratégiai jelentőséggel bírt, mivel a brit és az orosz birodalmak között helyezkedett el. Söt, az állam mai határai is az említett nagyhatalmak szándékai és érdekei mentén kerültek kialakításra. A britek a 19. század első felében elérték terjeszkedésük során az afgán határokat, több háborút is vívtak az afgánokkal, majd - a 19. század utolsó és a 20. század első évtizedeire - ki is terjesztették rájuk a befolyásukat, Afganisztán 1919-ben azonban
} 
(Afsah-Guhr [2005] pp. 388-392.) Ennek a ténynek a jelentősége - és relevanciája a területi igazgatás kapcsán - abban áll, hogy Afganisztán esetében a külső hatalom által irányított adminisztráció így nem rendelkezik precedenssel. Hozzá kell, hogy tegyük, hogy az államfogalom értelmezése is problematikusnak tünik, újabb sajátosság ugyanis, hogy Afganisztán esetében - persze nem csupán itt - az erős államnak nincsenek hagyományai. Az állam lényegében a különböző, általában törzsi hagyományok mentén szerveződő csoportok laza szövetsége, amely csak néhány közös, a kohéziót minimális szinten biztosító intézménnyel rendelkezik, ilyen például a szövetségi gyülés, a Loja Dzsirga, vagy korábban a király. A helyzetet tovább bonyolítja - és az előzőekből egyenesen következik -, hogy az alapvetően törzsi rétegzettségü társadalomban a nemzetfogalom sem értelmezhető, talán csak a huszadik század második felétől, a szovjet intervenció óta töltődött meg némi tartalommal. ${ }^{66}$

Afganisztán huszadik századi történelme bővelkedik eseményekben: puccsok zajlottak, a hidegháborús amerikai és szovjet versengés is éreztette hatását - ennek egyik tragikus fejezete volt az 1979 és 1989 közti szovjet intervenció. A szovjetek által támogatott rezsim 1992-ben megbukott és a - korábban a szovjetbarát rezsim ellen harcoló, amerikaiak által támogatott - mudzsahedek szerezték meg az irányítást, ők azonban képtelenek voltak megszilárdítani hatalmukat és kiterjeszteni az egész ország területére, ehelyett Afganisztán a hadurak irányítása alá került és polgárháborúba süllyedt. Ennek igyekeznek véget vetni 1996-ban a tálibok, akik uralmuk hét éve alatt aztán iszlám államot építettek ki, s kemény kézzel, számos humanitárius jogsértést elkövetve vezették az országot. Mindeközben az ellenzéki, ún. Északi Szövetség - amely a tálibrezsim ellenében szerveződő számos csoportot tömörített - az ország északkeleti csücskébe szorult vissza. A tálibok fogadták be az országba Oszáma bin Ládent - az alKáida terrorszervezet vezetőjét - és társait. (Barfield, [2010] pp. 249 - 260.)

2001. szeptember 11-én az al-Káida terrorszervezet több városban, összehangolt támadást hajtott végre az Amerikai Egyesült Államok ellen Erre reagálva az USAvezette koalíció megtámadta Afganisztánt azzal a céllal, hogy az al-Káida

újra független lett.

${ }^{66}$ Fontos megjegyezni, hogy nem a civilizációs-kulturális nézőpontból kitekintve említjük meg mindezeket a tényeket, és nem arra szeretnénk utalni, hogy a külső államépítési kísérletek az említett okok miatt eleve kudarcra vannak ítélve - csupán arra tettünk kísérletet, hogy a körülményeket bemutassuk. 
terrorszervezetet felszámolja és megdöntse az azt támogató tálib-rezsimet, utóbbi sikerült is 2011. novemberre. December 5-én lezárult a bonn-petersbergi konferencia, itt elfogadták azt a többlépcsős rendezési tervet, amely az afganisztáni demokratikus átalakítás és helyreállítás lépéseit és a nemzetközi szerepvállalás kereteit volt hivatott meghatározni. A nemzetközi szerepvállalás katonai aspektusának megvalósítására létrehozták az ISAF-ot (International Security Assistance Force), a polgári igazgatás központi intézménye pedig az UNAMA (United Nations Assistance Mission in Afghanistan) lett, mindkettőt BT-határozat hozta létre. ${ }^{67}$

A nemzetközi beavatkozásról élénk vita zajlott, amelyben a kulcskérdés az volt, hogy mekkora teret engednek az ENSZ-nek az afganisztáni újjáépítési folyamatban. Az eredmény végül a Lakhdar Brahimi egykori afganisztáni ENSZ-különmegbízott által kidolgozott és az ENSZ főtitkárának jelentésében közzétett és a mérsékelt beavatkozást preferáló ún. light footprint stratégia ${ }^{68}$ lett, (A/56/875-S/2002/278 [2002]) amelynek értelmében a nemzetközi igazgatásnak mindenekelött a helyi közigazgatásra kell támaszkodnia, azt támogatnia, szem előtt tartva a helyi struktúráknak és azok felelősségének elsődlegességét. A limitált beavatkozás mentén az ENSZ szerepvállalása elsősorban a civil igazgatásban értelmezhető, a multinacionális katonai szerepvállalásban kezdettől fogva az USA játszotta a meghatározó szerepet (bár a misszió irányítása hathavonta más államhoz került), 2003-tól pedig a NATO hivatalosan is átvette az ISAF irányítását.

A polgári igazgatásban az ENSZ BT határozatokban meghatározott eredeti, majd később kibővített mandátuma meglehetősen általános és korlátozott volt, s a következő területekre terjedt ki: a kormány támogatása az olyan kritikus területeken, mint a biztonság, a kormányzás, a gazdaságfejlesztés és a regionális kooperáció; a későbbi 2010 januárjában Londonban, 2010 júniusában pedig Kabulban tartott - konferenciákon elfogadott rendelkezések végrehajtásának előmozdítása; az emberi jogoknak, különösen a nők és gyermekek védelmének biztosítása; valamint más, a helyszínen tevékenykedő nemzetközi szervezetekkel való együttmüködés. (UN Peacekeeping Operations -

\footnotetext{
67 Az ISAF-ot létrehozó dokumentum: S/RES/1386 (2001) of 20 December 2001.; az UNAMA felállításáról rendelkező BT határozat: S/RES/1401 (2002) of 28 March 2002.

68 A kifejezés fordítására kevesen vállalkoznak, akik igen, azok általában a „könnyü lábnyom” fordítást használják. A témáról és az afganisztáni nemzetközi szerepvállalás kapcsán ld. Marton Péter (2009): Az államépítés sorrendisége és az afganisztáni bonyodalmak. Külügyi Szemle, 1. sz., pp. 18-40.
} 
UNAMA [é.n.]) Az afganisztáni rendezés egyik sajátossága azonban az is, hogy a legfőbb rendező dokumentumot, a bonni megállapodást sokkal inkább értelmezhetjük egy, a további tárgyalások alapvető irányait meghatározó keretegyezmények, semmint a kívánatos végleges állapotokat bebetonozó megállapodásnak. Az ENSZ-nek lehetősége nyílt arra, (Chesterman [2004] p. 91.) hogy mindig a változó körülményeknek megfelelően tudja az afganisztáni intézményeket támogató tevékenységét kifejteni és így hatékonyabban müködni. Az afganisztáni szerepvállalás egyik lényeges jellemzője ez, mert így az ENSZ nem szorult be tehetetlenül abba csapdába, amibe Bosznia esetében a daytoni megállapodás, Koszovó esetében pedig az 1244. számú BT határozat gyakran erre kényszeríti. A nemzetközi szerepvállalás ezen rugalmas keretébe illeszkednek a folyamatosan szervezett találkozók és konferenciák, ahol az aktuális eseményeket tárgyalták meg a felek és ennek megfelelően hozták meg döntéseiket. Ezek közül az egyik legfontosabb a 2006. januári londoni konferencia és az ott elfogadott Afganisztáni Egyezmény (Afghanistan Compact), ${ }^{69}$ amely a bonni folyamatot lezárva annak helyébe lépett és 2010-ig irányozta elő a követendő stratégiát: itt a hangsúly már nem az intézmények felállításán volt - hiszen ez a bonni folyamatban megtörtént -, hanem a hatékony müködtetésükre helyezödött. Szintén ezen a konferencián fogadták el az Afgán Nemzeti Fejlesztési Stratégiát (Afghanistan National Development Strategy ANDS), ${ }^{70}$ amely az afgán kormányzat legfontosabb feladatait vette számba, s meg kell még említenünk a 2008-as párizsi, majd a - fentebb már említett - 2010-es londoni és kabuli konferenciákat. (UN Peacekeeping Operations - UNAMA [é. n.])

\subsubsection{Irak}

Mai területén az első világháború után jött létre Irak, ekkor a népszövetségi mandátumrendszer részeként Nagy-Britannia irányítása alá került több más, korábban az Oszmán Birodalomhoz tartozó területtel együtt. 1932-ben a független Irak ugyan de iure létrejött, a britek azonban továbbra is befolyásuk alatt tartották a királyságot. Irak történelme bővelkedik véres puccsokban, amelyek a hatalomváltást rendre biztosították, nem volt ez másként a hidegháború évtizedeiben sem. 1958-ban időközben Irak köztársaság lett, a hatvanas években pedig hatalomra került a szocialista ideológiát magáénak valló Baász Párt, amelynek egyik vezetője, Szaddám Huszein, 1979-ben

\footnotetext{
${ }^{69}$ A dokumentum teljes szövegét ld.: The Afghanistan Compact.

${ }^{70}$ Islamic Republic of Afghanistan Afghanistan National Development Strategy 1387-1391 (2008-2013)
} 
magához ragadta a hatalmat. Több, az országban kisebbségben élő vallási és etnikai csoporttal (siíták, kurdok) szemben elnyomó politikát alkalmazott a rezsim, amire válaszul többször rendszerellenes megmozdulások zajlottak az országban; ráadásul szomszédai közül Irak a nyolcvanas években Iránnal keveredett csaknem egy évtizedes háborúba (első Öbölháború, 1980-1988), majd Kuvaitot szállta meg (második Öbölháború, 1991). Utóbbi esetében az Amerikai Egyesült Államok vetett véget a válságnak úgy, hogy támadást intézet Irak ellen, Szaddám Huszein végül kénytelen volt kivonulni Kuvaitból, s - mivel az amerikaiak a beavatkozás után nem döntötték meg a rezsimjét - elviselni a vereséggel járó következményeket. Ezek egyike volt az a nyugati követelés, (S/RES/687 [1992]) hogy Irak semmisítse meg tömegpusztító fegyvereit, s engedje be a nemzetközi ellenőrző missziót országa területére. ${ }^{71}$ (Marr [2011] p. 237.) 1998-ban Irak kiutasította a fegyverzetellenőröket, megszegve nemzetközi kötelezettségeit, s ezzel megteremtve a 2003-as harmadik Öbölháború egyik hivatkozási alapját.

Az Amerikai Egyesült Államok vezetésében már 1998-ban megfogalmazódott a szándék a Szaddám-rezsim megbuktatására, prioritást azonban csak a 2001. szeptember 11-i terrortámadás után kapott, az ún. gonosz tengelye ${ }^{72}$ ellen vívott küzdelem részeként. Az USA 2003. március 19-én megtámadta Irakot, a hivatalos okok között a tömegpusztító fegyverek megléte és a nemzetközi terrorizmus támogatása állt, később mindkettőről kiderült, hogy gyenge lábakon álló vádak, s maradéktalanul egyik sem bizonyítható. (Marr [2011] pp. 261-263.) A beavatkozással a másik súlyos probléma, ami aláásta az amerikai akció nemzetközi jogi legitimitását, hogy nem volt kifejezett és előzetes BT felhatalmazás a hadművelet megindítása előtt. 2003. május elejére a Szaddám-rezsimet sikerült megdönteni, ekkor azonban sürgetően merült fel a kérdés, hogy miként igazgassák Irakot a győzelmet követően.

A válságot követő nemzetközi jelenlétről jelentős viták zajlottak, a fő kérdés az volt, hogy milyen szerepet szánjanak az ENSZ-nek. Közvetlenül a beavatkozást megelőzően úgy tünt, hogy - főként az USA európai szövetségesei, a britek nyomására - jelentős

\footnotetext{
${ }^{71}$ A nemzetközi ellenőrző ENSZ-misszió az UNSCOM (United Nations Special Commission) volt (http://www.un.org/Depts/unscom/), amely együttmüködött a Nemzetközi Atomenergia Ügynökséggel (International Atomic Energy Agency - IAEA) (www.iaea.org)

${ }^{72}$ A kifejezést George Bush használta elsőként 2002 januárjában, amikor a gonosz tengelyéhez sorolta Irak mellett Iránt és Észak-Koreát is.
} 
szerepet szánnak majd a világszervezetnek az iraki újjáépítési folyamatban. Időközben azonban az amerikai vezetésben a Bush enök és a védelmi minisztérium által preferált irány kerekedett felül, miszerint a válság után az USA játssza a főszerepet az iraki rendezésben. Mindazonáltal az ENSZ-nek is juttattak szerepet, többek között azért is, hogy az USA katonai intervencióját követően a nemzetközi jelenlét legitimációs bázisa erősebb legyen a nemzetközi, és nem utolsósorban a helyi, iraki környezetben. (Chesterman [2004] p. 93.) Az ENSZ ennek megfelelően - hivatalosan az iraki ideiglenes vezetés kérése nyomán - az 1500. számú BT határozattal létrehozta az ENSZ Iraki Segélymisszióját, (S/RES/1500 [2003]) az UNAMI-t (United Nations Assistance Mission in Irak), amelynek munkáját az ENSZ által delegált különleges megbízott ${ }^{73}$ irányította. Az UNAMI mandátuma meglehetősen korlátozott volt, s lényegében a formálódó iraki hatalmi szervek támogatására és tanácsokkal való ellátására szorítkozott, ${ }^{74}$ valamint tevékenységi körébe tartozott az Irakban tevékenykedő számos ENSZ-intézmény munkájának koordinálása.

A tényleges hatalom, amint erre már utaltunk, az amerikai katonai beavatkozást közvetlenül követően az Egyesült Államok kezébe került, pontosabban a Pentagon alá tartozó egyik intézményhez, a még 2003 januárjában létrehozott ORHA-hoz (Office for Reconstruction and Humanitarian Assistance). A szervezet néhány hónapos müködése kevés figyelmet érdemel, annál inkább jelentős a megszűnése nyomán (és a feladatait átvéve) létrejött Koalíciós Átmeneti Hatóság (Coalition Provisional Authority - CPA). (Marr [2011] p. 258.) A CPA - élén az ún. kormányzóval - átmeneti kormányzószervként működött, amely az adminisztrációs funkciók teljes skáláján tevékenykedett, tehát a végrehajtó, a törvényhozó és a bírói ágakban is. A CPA is az USA védelmi minisztériumának egyik intézménye volt, jelentéstételi kötelezettsége a védelmi miniszter felé volt. 2004. június 28-án fejezte be müködését, ekkor minden hatalmát átadta az újonnan létrejött Iraki Ideiglenes Kormánynak. (Chesterman [2004] p. 95.) A nemzetközi katonai jelenlétről ehelyütt annyit érdemes megjegyezni, hogy az itt állomásozó kontingens többnemzetiségü, a koordinált irányítás pedig szintén az USA feladata.

\footnotetext{
${ }^{73}$ Az első különleges megbízott a brazil diplomata, Sérgio Vieira de Mello volt, aki áldozatul esett a 22 halálos áldozatot követelő, az ENSZ misszió központja ellen intézett bombatámadásnak 2003. augusztus 19-én. A merényletet az al-Káida vállalta magára. A nemzetközi területi igazgatás történetében valószínủleg ez volt a legtöbb civil nemzetközi tisztségviselő halálát követelő támadás. (Marr [2011] p. 275.)

${ }^{74}$ A mandátumról ld. részletesen: UNAMI mandate.
} 
Az iraki nemzetközi területi igazgatás több szempontból is sajátos. Elsőként érdemes kiemelnünk, hogy - hasonlóan az afganisztáni misszióhoz - ez is a terrorellenes harc részeként végrehajtott beavatkozást követően kezdte meg müködését. Másodsorban azért is egyedi, mert a területi igazgatások esetében a nemzetközi jelenlét általában azért válik szükségessé, mivel a helyi állami intézményeket vagy valamilyen belső megosztottság vagy hatalmi versengés, vagy a müködésképtelenség akadályozza abban, hogy ellássák feladatukat. Irakra ezek egyike sem volt jellemző, itt a humán, az intézményi és a gazdasági kapacitásoknak az állam müködéshez szükséges mértéke rendelkezésre állt. (Chesterman [2004] p. 96-97.) Szintén speciálisnak tekinthető Irak abban a vonatkozásban is, hogy az ENSZ szerepe a nemzetközi polgári igazgatásban kifejezetten marginális, s a katonai intervenciót végrehajtó állam, az USA irányítja a nemzetközi adminisztráció - kezdeti, meghatározó szakaszában legalábbis - polgári és (egyébként multinacionális kivitelezésü) katonai aspektusát is.

\subsection{A nemzetközi területi igazgatás osztályozása}

\subsubsection{A beavatkozás mértéke szerinti osztályozás}

A nemzetközi területi igazgatás csoportosításának nehézsége egyfelől abban rejlik, hogy minden egyes gyakorlati példa több, egyedinek tekinthető sajátossággal bír, másfelől abban, hogy nincs kialakult - és a nemzetközi szereplök által elfogadott - koherens stratégia és szabályrendszer. Wolfrum szerint az összehasonlítás alapját meghatározott szempontok szerinti összehasonlíthatóság adja - ezek hasonlósága illetve különbözősége teremt lehetőséget az osztályozásra - a szempontok pedig a következők:

1. a nemzetközi jelenlét jogi alapja,

2. a nemzetközi igazgatás mandátuma (jogosultságok köre),

3. a célok és végül

4. a résztvevők. 
Ez alapján a nemzetközi igazgatás két megközelítése különböztethető meg: az elsőnél a célállamban a nemzetközi szereplő tevékenysége alapvetően a technikai segítségnyújtásra korlátozódik (pl. népszavazás lebonyolítása, választások felügyelete stb.), a második megközelítésnél pedig már közvetlen igazgatási funkciókat is átvesz a beavatkozó fél. Az első csoport (technikai segítségnyújtás) tovább bontható két alcsoportra aszerint, hogy ki a beavatkozás alanya: egyik esetben az ENSZ vagy megbízásából egy másik nemzetközi szervezet, másik esetben egy állam vagy államok egy csoportja - a második esetre is jellemző azonban, hogy a beavatkozó állam / államok az ENSZ felhatalmazásának birtokában tevékenykednek. (Wolfrum [2005] p. 656.)

Ennél a csoportosításnál számunkra a második megközelítés különösen érdekes vagyis az a kategória, amikor a beavatkozó fél már közvetlen igazgatási funkciókat is ellát a célállamban -, mert a dolgozat elemző részének tárgyát képező mindkét balkáni példa, a boszniai és a koszovói is ebbe a kategóriába tartozik. Lényeges azonban a különbség a két eset között annyiban, hogy míg a koszovói UNMIK keretein belül kezdettől fogva széles körben valósult meg a közvetlen igazgatás, Boszniánál a nemzetközi adminisztráció jellege az idők során változott, s így delegáltak egyre több és több jogosítványt a nemzetközi polgári jelenlét legfőbb letéteményesének, a fömegbízottnak.

A nemzetközi területi igazgatás fenti csoportjaiba a történelmi példák viszonylag nehézség nélkül besorolhatók, bár vannak olyan példák, amelyek besorolása attól függ, hogy mely tulajdonságaikat helyezzük a vizsgálódás fókuszába, más példák esetében pedig - az adott eset speciális karakterisztikái alapján - a fenti csoportosítás szerinti osztályozás nem lehetséges.

A technikai segítségnyújtásra jellemzően az ENSZ vállalkozik - így volt ez a hatvanas években indított két afrikai misszióban, az ONUC-ben ${ }^{75}$ és az UNTAG-ban ${ }^{76}$ is -,

\footnotetext{
${ }^{75}$ Bár már foglalkoztunk ezzel a misszióval a történeti fejezetben (Kongó-ONUC: 1.3.2.2. alfejezet), a kongói missziónál említésre érdemes, hogy az hivatalosan ugyan a technikai segítségnyújtás kategóriájába tartozott, valójában azonban a nemzetközi komponens feladata ezen a szinten túlmutatott, amennyiben az ONUC kormányzati funkciókat is ellátott.

${ }^{76}$ Szintén volt szó már az UNTAG-ról (1.2.3.4. afejezet). Az 1966-ban létrehozott Namíbiai Tanácsot (Council of Namibia) a kilencvenes években váltotta fel az UNTAG, amely az ENSZ fötitkára különleges képviselöje irányítása alatt állt, s tevékenységi köre szűkebb volt, mint az ONUC-é. (Wolfrum [2005]
} 
megvalósulhat azonban úgy is, hogy a célállamban más nemzetközi szervezetek, államok vagy államcsoportok a nemzetközi területi igazgatás alanyai (ám ezen szereplők is az ENSZ kifejezett felhatalmazása alapján vannak jelen). Az ENSZ BTfelhatalmazással tevékenykedő regionális nemzetközi szervezetek közül Sierra Leonéban az ECOWAS, ${ }^{77}$ a boszniai Mostarban az Európai Unió irányít, Koszovóban pedig a NATO a nemzetközi biztonsági jelenlét legfőbb letéteményese. A második világháború utáni, új alapokra helyezett nemzetközi rendszerben a nemzetközi területi igazgatás megvalósulásának egyik első példája Líbia, ahol két állam: Nagy-Britannia és Franciaország képviselték a nemzetközi közösséget, míg az évszázad végén KeletTimorban Ausztrália, Szomáliában és Irakban pedig az Egyesült Államok ${ }^{78}$ voltak a beavatkozás központi szereplői. Afganisztánban sajátos megoldás érvényesült: itt is megjelennek a vezető hatalmak, de központi szerepük csak szektorális keretek között, az általuk irányított területen van. ${ }^{79}$ (Wolfrum [2005] pp. 658-659.)

A nemzetközi területi adminisztráció második típusa az, amikor a beavatkozó fél már közvetlen kormányzati funkciókat is átvesz a célállamban. Erre a közvetlen irányításra már a népszövetségi időkből is hozhatunk példákat, így Gdańsk esetét, amikor a „szabad város” 1919 és 1939 között a Nemzetek Szövetsége irányítása alatt állt, élén a szervezete főmegbízottjával. Szintén ebből az időszakból említhető a Saar-vidék, amit a versailles-i békeszerződés értelmében 1920 és 1935 között közvetlenül irányított a Népszövetség egy bizottságon keresztül, amely a kormányzati feladatok ellátásáért felelt, egészen addig, amíg a 15 év leteltével meg nem tartották a népszavazást a terület végső hovatartozásáról. Szintén népszövetségi, de már nem európai példa a kolumbiai Leticia, ahol - miután Peru elfoglalta a területet és így viszály keletkezett a két állam között a terület hovatartozását illetően - 1933-1934-ben gyakorolta a közvetlen irányítást az univerzális szervezet. ${ }^{80}$ (Wolfrum [2005] pp. 659-660.)

pp. 657-658.)

Economic Community of West African States - ECOWAS / Communauté économique des États de l'Afrique de l'Ouest - CEDEAO: a nyugat-afrikai régió 1975-ben létrehozott, s a gazdasági integráció előmozdítását megcélzó szervezete, jelenleg 15 tagja van.

${ }^{78}$ Irakban az ún. vezető hatalmakkal kiegészülve, de az USA vezető szerepével, az ENSZ korlátozott szerepvállalása mellett.

79 Például Németország felelt elsődlegesen a rendőrség felállításáért, Olaszország pedig az igazságszolgáltatás kiépítéséért.

${ }^{80}$ A történeti részné részletesebben volt róluk szó, vö. 1.3.1.1. (Saar), 1.3.1.2. (Gdańsk) és 1.3.1.5.-ös (Leticia) alfejezetekkel. 
A népszövetségi esetek tekinthetők az ENSZ-igazgatás egyfajta előzményének, a közvetlen irányítás gyakorlata azonban igazán az évszázad második felében teljesedett $\mathrm{ki}$ - akkor is inkább ${ }^{81}$ a poszthidegháborús időszakban -, s kontúrjai is szükségképpen változtak a nemzetközi környezet változásainak megfelelően. Ezen változások egyik legfontosabbikaként említi Stahn azt, hogy az ENSZ békefenntartó gyakorlata nyomán hogyan módosult a funkcionális munkamegosztás a különböző ENSZ-szervek között. A népszövetségi időkben és az ENSZ müködésének kezdetén még a föszervek voltak közvetlenül felelősek a felügyeletért, később azonban egyre inkább az vált jellemzővé, hogy a Biztonsági Tanács és a Közgyülés továbbutalta az igazgatási felelősséget az ENSZ főtitkárának, aki pedig ledelegálta egy általa megbízott tisztségviselőnek (főmegbízott vagy különleges megbízott), akinek a feladata az volt, hogy a célállamban lássa el a mandátumban meghatározott feladatokat. A Biztonsági Tanács megtartja magának a jogot a nemzetközi adminisztráció létrehozására (felhatalmazás, mandátum meghatározása), a végrehajtásról azonban lemond, az ellenőrzésben viszont ismét ő játssza a főszerepet, amennyiben a végrehajtásért felelős intézmények a BT-nek jelentenek rendszeres időközönként. (Stahn [2008] p. 396.)

Rátérve a közvetlen irányítás példáira: az ENSZ direkt irányítása alatt állt Kambodzsa 1992-1993-ban, s itt is egy nemzetközi szerződés (az 1991. szeptemberi párizsi szerződés) alapján döntött az ENSZ BT az UNTAC ${ }^{82}$ létrehozásáról 1992-ben. A világszervezet kambodzsai missziója komplex nemzetközi területi adminisztráció volt (a későbbi példák közül az UNTAET-re és az UNMIK-ra hasonlít ebben), ahol a végrehajtó hatalmon túl az ENSZ a törvényhozói hatalmat is gyakorolta, sőt az igazságszolgáltatásban is jelentős jogosítványai voltak. A délszláv háború lezárását követően Horvátországnak a szerbek lakta és a háború idején az ő irányításuk alatt levő területein - Kelet-Szlavóniában, Baranyában és a Nyugat-Szerémségben - állt fel az UNTAET. A közvetlen irányítás létrehozásáról a Horvátország és a horvátországi szerbek által megkötött erduti megállapodás ${ }^{83}$ alapján került sor, amelynek nyomán a

\footnotetext{
${ }^{81}$ A hidegháborús időszakban viszonylag kevés példát találunk a közvetlen igazgatás megvalósulására, az egyik ilyen az UNTEA (részletesebben ld. 1.3.2.3. alfejezetet), amelynek az volt a funkciója, hogy biztosítsa: a vitatott státuszú Nyugat-Új-Guinea békés módon kerül át az átmeneti közvetlen irányítás végén Hollandiától Indonéziához. (UN Peacekeeping Operations - UNSF [é. n.]) Az ENSZ-misszió itt sajátos módon a felek által aláírt, s ENSZ-közvetítéssel tető alá hozott nemzetközi kormányközi megállapodás (az 1962. szeptemberi new yorki megállapodás) alapján jött létre. Az átmeneti időszakban a szervezet birtokolta a végrehajtó hatalmat. (Wolfrum [2005] p. 661.)

${ }^{82}$ UNTAC (részletesebben ld. az 1.3.2.6. alfejezetben)

${ }^{83}$ A szerződés (amelyet 1995 novemberében kötöttek a felek) hivatalos elnevezésében az „alapszerződés”
} 
különleges megbízott meghatározott végrehajtó jogosítványokat átvett a helyi intézményektől. ${ }^{84}$ (Wolfrum [2005] pp. 661-662.) Az egyik legerősebb végrehajtói hatalommal rendelkező nemzetközi területi igazgatás Koszovóban valósult meg a koszovói válság 1999. júniusi lezárása után, itt is direkt irányítás érvényesül. A nemzetközi jelenlét két pillére az ENSZ vezette, több nemzetközi szervezet részvételét koordináló civil igazgatási misszió, az UNMIK; és a biztonságot szavatoló, ENSZfelhatalmazással idevezényelt békefenntartó NATO-erö, a KFOR. ${ }^{85}$ A közvetlen igazgatás utolsó, általunk említett példája az 1999-től Kelet-Timorban müködő UNTAET, ${ }^{86}$ amely a közvetlen igazgatási missziók közül egyértelmüen a legkiterjedtebb hatalommal rendelkező példa volt, ami a terület teljes irányítását átvette annak 2002 tavaszi tényleges függetlenségéig. (Wolfrum [2005] p. 663.)

A nemzetközi területi igazgatási fenti osztályozása alapján egyik csoportba sem sorolható, hanem külön kategóriát képez a Bosznia-Hercegovinában megvalósuló igazgatási modell. A boszniai misszió elsősorban amiatt tekinthető speciálisnak, hogy az idők során jelentős változásokon ment át anélkül, hogy lényegi tulajdonságai (legitimitás, struktúra, elnevezés stb.) módosultak volna. Az eddig felsorol példáknál tapasztalhattuk, hogy nem ritka, hogy a misszió feladatköre átalakult (a megváltozott környezetnek és igényeknek megfelelően), de mindenütt azt láthatjuk, hogy az irányító nemzetközi szereplö (általában az ENSZ) ilyenkor új szervezeti alapokra helyezte a nemzetközi jelenlétet. Vagyis új alapító dokumentummal (általában BT határozattal), más elnevezéssel és eltérő mandátummal létrehozott egy új intézményt. Bosznia esetében ez nem így történt: az intézményrendszer nem változott, a misszió legitimációs bázisaként szereplő Daytoni megállapodást sem váltotta fel egy új dokumentum, ehelyett egy azt kiegészítő dokumentumban (Bonn powers) rögzítették az új szerepkört.

A közvetlen igazgatás kategóriáját Stahn is használja saját osztályozásánál, ő a direkt és az indirekt igazgatást különbözteti meg egymástól. Nála a közvetlen igazgatás definíciója a következö: a nemzetközi igazgatás alanyai (végrehajtója) a nemzetközi

\footnotetext{
kifejezés szerepel. Forrás: UN Peacekeeping Operations - UNTAES.

${ }^{84}$ A közvetlen irányításra további példák is említhetők, pl. Koszovó (UNMIK, KFOR).

${ }^{85}$ Az UNMIK-ról, a KFOR-ról (Kosovo Force - KFOR) és a koszovói direkt irányítás egyéb jellemzőiről a koszovói esettanulmányban részletesebben is szó lesz. (3. fejezet)

${ }^{86}$ A függetlenség kikiáltását követően az UNTAET-et felváltotta 2002-től az UNMISET (United Nations Mission of Support to East Timor), majd 2005-töl az UNOTIL (United Nations Office in East Timor). Mindhárom missziót ENSZ BT határozattal hozták létre. (részletesen ld. 1.3.2.10. alfejezetben)
} 
szervezetek szervei, kiegészítő szervei, vagy olyan egyéb intézmények, amelyeket a nemzetközi szervezetek közvetlenül hatalmaznak fel az igazgatási feladatok ellátására. Ezzel szemben a közvetlen igazgatást az jellemzi, hogy egy jogi személyiséggel rendelkező nemzetközi intézmény gyakorolja az igazgatási jogokat a felhatalmazó nemzetközi szervezet megbízása és mandátuma alapján, anélkül azonban, hogy maga az adott nemzetközi szervezethez tartozna. (Stahn [2008] p. 397.)

Stahn a direkt-indirekt felosztás mellett még kétfajta szempontból csoportosítja a nemzetközi szervezeteket. Egyrészt annak alapján, hogy mennyire osztják meg egymás közt az igazgatás felelősségét a területi adminisztráció nemzetközi alanyai, megkülönbözteti a kizárólagos adminisztrációt (exclusive governance) a társ-igazgatás (co-governance) esetétől, sőt alkot egy harmadik kategóriát is, a támogató missziót (assistance mission). ${ }^{87}$ (Stahn [2008] pp. 397-398.)

\subsubsection{Célok, funkciók szerinti osztályozás}

Az átmeneti jellegü nemzetközi igazgatási missziók csoportosítása többféle szempont alapján lehetséges Chesterman szerint is, aki úgy véli, hogy a leginkább egyértelmü a nemzetközi igazgatási szerveknek juttatott hatalom szerinti kategorizálás. Az ideiglenes nemzetközi igazgatási missziók esetében két igen lényeges jellegzetességet figyelembe kell venni a csoportosításnál. Az egyik az adminisztráció átmeneti jellege - a nemzetközi szerveknek juttatott hatalom, jogosítványok puszta leírása ugyanis nem tartogathat számunkra sok mondanivalót -, a másik pedig az a tény, hogy a nemzetközi igazgatási rendszerek mindig egy adott környezetben müködnek, s ezen társadalmipolitikai-gazdasági környezet jellegzetességei határozzák meg a müködés feltételeit és hordozzák magukban a lehetséges kockázati tényezőket. Chesterman az előző okfejtésből kiindulva a célokat és a helyi politikai környezetet figyelembe véve az alábbi csoportosítást javasolja az átmeneti nemzetközi igazgatás esetében (ehelyütt nem mutatjuk be részletesen az egyes példákat, csak zárójelben jeleztük, hogy azok a csoportosítás mely pontjának feleltethetők meg):

${ }^{87}$ A Stahn-féle - a kizárólagosság-megosztottság dichotómia mentén történő - osztályozásra példák: 1. kizárólagos: Saar, Leticia, Nyugat-Új-Guinea, Namíbia, Kelet-Szlavónia, Koszovó, Kelet-Timor; 2. társigazgatás: Gdańsk, Kongó, Kambodzsa, Szomália, Bosznia; 3. támogató misszió (Memel, Líbia, Eritrea, Namíbia, Nyugat-Szahara, Afganisztán, Irak, Libéria, Kongó) (Stahn [2008] pp. 397-398.) 
1. dekolonizációs folyamatot kísérő: itt a nemzetközi igazgatás célja, hogy a teljes függetlenséghez vezető úton nyújtson segítséget a születő államnak (pl. Namíbia, Kelet-Timor);

2. területátadást kísérő: az adott terület az érintett felek közti megállapodás értelmében egy szuverén állam fennhatósága alá kerül az átmeneti igazgatás időszakát követően (pl. Nyugat-Új-Guinea, Nyugat-Szahara, Kelet-Szlavónia);

3. választásokat kísérő: az ideiglenes igazgatás a demokratikus választások lebonyolítását követően véget ér, ha az adott állam lakossága akaratának megfelelően felállt az új kormányzat (pl. Kambodzsa);

4. békefolyamatot kísérő: az ideiglenes nemzetközi igazgatás egy konfliktus lezárását követően kezd müködni általában úgy, hogy a misszió mandátuma lejáratának időpontját nem definiálják (pl. Bosznia-Hercegovina, Koszovó);

5. anarchiát kísérő: de facto igazgatás, amikor az állami struktúra szétesése következtében az állam müködésképtelen (pl. Kongó, Szomália, Sierra Leone). (Chesterman [2004] pp. 56-86.)

Az előző osztályozáshoz hasonló kategóriákat fogalmaz meg Stahn, amikor funkciók szerint csoportosítja a nemzetközi igazgatás egyes eseteit. Ennek alapján négy olyan politikai célt tudunk elkülöníteni, aminek beteljesítése a nemzetközi területi adminisztrációk célja lehet. (A funkcionális csoportosítás egyes elemeinél zárójelben soroljuk fel a példákat. Ugyanaz az eset több kategóriában is megjelenhet attól függetlenül, hogy a nemzetközi közösség céljai mik voltak eredetileg, és ez hogyan változott az idők során.) (Stahn [2008] pp. 395-406.)

1. Területi viták rendezése - minden bizonnyal az egyik legrégebbi szerep, amit a nemzetközi igazgatásnak be kellett töltenie, három fajtája létezik:

- státuszrendezés: egy válság sújtotta területen a szemben álló felek mindegyike igényt tart, általában történeti-politikai-kulturális okokra hivatkozva (Saarvidék, Koszovó)

- semlegesítés: a terület hovatartozása itt is vitatott, a nemzetközi adminisztráció célja, hogy elszigetelje azt a szembenálló felek mindegyikétől a feszültségek csökkenése érdekében, és nemzetközi igazgatás alá vonja a békés rendezésig (Gdańsk; s ez lett volna a trieszti és jeruzsálemi igazgatás célja is, ha 
megvalósultak volna). A nemzetközi igazgatás azonban minden esetben ideiglenesnek bizonyult (néhol az eredeti, az állandóságot sem elvető elképzelések ellenére). Idővel az ENSZ gyakorlatába úgy épült be a semlegesítést célzó nemzetközi jelenlét, hogy már létrejöttekor is átmeneti megoldásnak szánták, amíg az adott terület kormányzati struktúráját meg nem szilárdítja egy válságot követően (Kambodzsa, Koszovó), ez az eset azonban már egy következő kategóriához vezet bennünket, az államépítéshez (ld. alább).

- területátadás: a nemzetközi területi igazgatás addig müködik, amíg a szóban forgó terület át nem kerül végső tulajdonosa fennhatósága alá (pl. Nyugat-ÚjGuinea, Kelet-Szlavónia). A nemzetközi adminisztráció egyik legsikeresebb funkciójának bizonyult ez, ennek oka pedig a világos mandátum és a felek megállapodásán nyugvó megvalósítás.

2. Dekolonizáció: az ENSZ gyakorlatában a népek önrendelkezési jogának érvényre juttatása volt az elsődleges funkciója a területi igazgatás egyes eseteinek. Ezek az igazgatási struktúrák akkor álltak fel, ha a döntéshozó hatalmak nem tudtak megállapodni egy-egy terület hovatartozásáról a függetlenedéskor (Líbia és Eritrea esetében a korábbi olasz gyarmati területek felosztásában nem volt konszenzus a második világháború győztes hatalmai között); vagy ha a korábbi gyarmatosító és egy, a területtel szomszédos hatalom között feszültek ellentétek a terület végső státuszát illetően (pl. Kelet-Timor esetében Hollandia és Indonézia között); vagy külön érdemes megemlíteni itt Namíbia speciális esetét, amikor egy nemzetközi szervezet (az ENSZ) és egy regionális hegemón (DélAfrika) keveredett vitába.

3. Államépítés: itt a válság sújtotta társadalmak államépítési folyamatainak előmozdítására áll fel a nemzetközi igazgatás, ezek az esetek a második világháborút követő időszakban jellemzőek. (pl. Kongó, Kambodzsa, Koszovó, Afganisztán, Irak, Libéria, Elefántcsontpart).

4. Intervenció legitimálása: ezekben az esetekben a válság lezárása céljából a nemzetközi közösség tagjai (szervezetek vagy államok csoportjai) fegyveres erőszakot alkalmaztak (BT felhatalmazással vagy anélkül), a háború lezárulása után pedig azonnal felállt a nemzetközi igazgatás (Koszovó, Irak, Afganisztán). Természetesen ez nem azt jelenti, hogy a BT felhatalmazás hiányában - pl. Koszovó esetében - a felálló nemzetközi területi adminisztráció ex post facto hatállyal legitimálta volna a válságot lezáró NATO-bombázásokat. Ez a mai 
nemzetközi rendszerben nem megengedett, mivel a felhatalmazásnak mindig explicitnek kell lennie, és a beavatkozást megelőzően kell, hogy az arra illetékes szerv (ENSZ BT) döntsön róla. Nem a NATO akcióját legitimálta tehát a felálló nemzetközi igazgatás, hanem a beavatkozás szükségességét igazolta.

Wilde a nemzetközi igazgatás funkció szerinti csoportosításánál mindössze két kategóriát alkot: (Wilde [2001] pp. 586-602.)

1. a „,Szuverenitás-probléma” megoldására létrehozott nemzetközi igazgatási modellek semleges térbeli identitásuknak köszönhetően lehetnek alkalmasak azon helyzetek megoldására, amikor egy adott terület hovatartozás miatt nézeteltérés van a helyi szereplők között (pl. Leticia, Nyugat-Új-Guinea, Kelet-Szlavónia, Saar, Mostar).

2. a „kormányzás-probléma” felszámolása céljából felállított nemzetközi területi adminisztráció esetében már nem identitás-különbségekkel kell megküzdeni, hanem vagy azzal, hogy egyetlen helyi szereplő sem képes ellátni a kormányzati funkciók gyakorlásának funkcióját (ez a kormányzás hiányának esete), vagy azzal, hogy a kormányzati hatalom birtokosai nem megfelelő módon látják el e feladatokat, ami nem felel meg bizonyos politika célkitüzéseknek (ilyenkor beszélhetünk a ,jó kormányzás” hiányáról, pl. Kongó, Namíbia, Koszovó, KeletTimor).

Lényegében szintén a funkcionalitás oldaláról közelít a nemzetközi igazgatás felállításának szükségességéhez Wolfrum, amikor azt állítja, hogy a nemzetközi igazgatások kapcsán mindegyik gyakorlati példára elmondható, hogy a - helyi konfliktus lezárását követően megjelenő - nemzetközi jelenlét célja a kormányzati vákuum ideiglenes betöltése céljából áll fel, ám különbségek mutatkoznak a beavatkozás szükségességét magyarázó közvetlen okokat illetően (ez tehát Wolfrum immár második csoportosítása). Az okok:

- a kormányzati struktúra összeomlása a válság során vagy az államiság egyes konstitutív elemeinek sérülése (például az ország bizonyos területének kiválása nyomán, mint Kelet-Timor esetében);

- államon belül, különböző csoportok között zajló (gyakran etnikai) konfliktusok (Afganisztán);

- az állam felbomlása (Bosznia, Koszovó); 
- dekolonizáció (Namíbia);

- a terület idegen uralom vagy irányítás alá kerülése (Irak).

A nemzetközi igazgatás minden esetben ideiglenes jelleggel látja el a kormányzati funkciókat, majd átadja azokat a helyi, demokratikusan választott politikai szereplöknek. (Wolfrum [2005], p. 650.)

\subsection{A nemzetközi területi igazgatással kapcsolatban felmerülö vitás kérdések, problémák}

A továbbiakban érintünk néhány olyan kérdéskört, amelyek gyakran felmerülnek a nemzetközi területi adminisztrációk kapcsán, föként akkor, amikor azok értékeléséről van szó. Ezen témák egy része az eddig tárgyalt elméleti részekben is felbukkant (pl. a szuverenitás-probléma), ehelyütt azonban érdemesnek találtuk egy csokorba szedni őket.

\subsection{1. Önrendelkezési jog, szuverenitás}

Müködése során a nemzetközi igazgatás számos dilemmával küzd, ezek közül az egyik legfontosabb az önrendelkezési jog nyilvánvaló sérülése. A nemzetközi igazgatás keretei között ugyanis legtöbbször erősen korlátozott a célállam állampolgárainak azon joga, hogy államuk politikai-gazdasági berendezkedését illetően szabadon döntsenek, s demokratikusan megválasszák azt a politikai elitet, amelynek kezébe helyezik országuk irányítását. Az is igaz azonban, hogy ezen állampolgárok nagy valószínüséggel a későbbiekben sem tudnák ezeket a jogaikat gyakorolni a nemzetközi adminisztráció jelenléte nélkül.

Ami a szabályozó nemzetközi jogi környezetet illeti, mint a nemzetközi rendszer oly sok intézménye, a nemzetközi területi adminisztráció gyakorlatában is elöfordul, hogy egy jogi norma szembekerül egy másikkal. Itt ráadásul kogens normákról beszélünk, amelyek között nincs hierarchia, így széleskörü mérlegelés tárgya annak eldöntése, hogy az adott helyzetben a döntéshozó melyiknek biztosít elsőbbséget. Az ENSZ 
Alapokmánya hitet tesz egyrészt a népek önrendelkezési joga mellett, ${ }^{88}$ (ENSZ Ao. [1945] 1/2. cikk) másrészt a nemzetközi béke és biztonság megőrzésének fontosságát is vallja. ${ }^{89}$ (ENSZ Ao. [1945] 2/6. cikk) A kollíziós helyzetet remekül lehet szemléltetni Koszovó példáján. Azon túl, hogy az Alapokmányban mindkét elv előkelő helyen szerepel, a koszovói válságot lezáró 1244. számú BT határozatban is megjelenik egy ellentmondás. Szerepel benne ugyanis a Jugoszláv Szövetségi Köztársaság szuverenitása és területi integritása melletti állásfoglalás ${ }^{90}$ - paradox módon mindamellett, hogy dokumentum következményeként Szerbia szuverenitása alól kivonták a koszovói tartományt -, ugyanakkor megjelenik benne az az igény, hogy a koszovói népnek érdemi autonómiát biztosítsanak. És ezen a ponton el is érkeztünk az önrendelkezés belső és külső oldalához. A belső önrendelkezés alatt általában azt értjük, hogy egy népnek joga van ahhoz, hogy maga döntse el, milyen kormányzati formában kíván élni, de vonatkoztathatjuk arra az esetre is, amikor egy államban az ott kisebbségben élő közösség autonómiát kap. A külső önrendelkezés klasszikus értelmezése a tényleges függetlenséghez való jog (egy államra vonatkoztatva), de értelmezhetjük úgy is, hogy egy adott kisebbség - önrendelkezési jogával élve kiszakad az addig lakhelyéül szolgáló államból, és új államot alapít vagy csatlakozik egy szomszédos államhoz. A nemzetközi rendszerben mára már bevett gyakorlattá vált, hogy bizonyos kivételektől eltekintve (dekolonizáció, elnyomás) a nemzetközi közösség a belső önrendelkezést támogatja a külsővel szemben, vagyis nem támogatja a szecessziós megoldásokat. A BT szempontjából érthető ez a hozzáállás, hiszen a mai viszonyok között kicsi annak a valószínüsége, hogy egy államterület kiszakadása (az ott élő lakossággal együtt) békés úton mehetne végbe. Ez esetben pedig a BT a nemzetközi biztonság és béke megőrzésének szükségességét rendszerint előtérbe helyezi a népek önrendelkezési jogával szemben. Többek között ennek is köszönhető, hogy a státuszrendezést célzó erőfeszítések Koszovó esetében nem vezettek eredményre.

\footnotetext{
${ }^{88}$ Az Egyesült Nemzetek célja, hogy ,[...]a nemzetek között a népeket megillető egyenjogúság és önrendelkezési jog elvének tiszteletben tartásán alapuló baráti kapcsolatokat fejlessze és az általános béke megerösítésére alkalmas egyéb intézkedéseket foganatosítson;" (ENSZ Ao. [1945] 1/2. cikk)

89 „A Szervezet biztosítja, hogy amennyiben a nemzetközi béke és biztonság fenntartása érdekében szükséges, azok az Államok is, amelyek az Egyesült Nemzeteknek nem tagjai, ezeknek az elveknek megfelelően járjanak el." (ENSZ Ao. [1945] 2/6. cikk)

90 „újfent megerősítve a tagállamok elkötelezettségét a Jugoszláv Szövetségi Köztársaság és a régió többi államának szuverenitása és területi épsége iránt, a Helsinki Záróokmány és a 2 . melléklet rendelkezéseinek megfelelően”, [a nemzetközi polgári igazgatás] „a.végső rendezésig előmozdítja Koszovó érdemi autonómiájának és önkormányzatiságának megvalósulását, maradéktalanul figyelembe véve a 2. mellékletet és a Rambouillet-i egyezményeket"( S/RES/1244 [1999] preambulum és 11/a. cikk) (A Szerző saját fordítása.)
} 
A gyakorlatban esetenként változó, hogy a nemzetközi igazgatás minimális marad-e amellett, hogy a helyi politikai elit kezébe kerülnek a kormányzati jogkörök, vagy a nemzetközi jelenlét erős, és a végrehajtó hatalom birtoklására is kiterjed azzal a céllal, hogy egy átmeneti időszakot követően - immáron stabil viszonyok között - adja át az irányítást a helyi politikai elitnek.

A nemzetközi területi igazgatás kapcsán felvetődik a hagyományos szuverenitásértelmezés átértékelése. A szuverenitás - klasszikus meghatározása szerint - egy állam igényének elismerése arra nézve, hogy egy egyértelmüen definiált terület felett a főhatalom gyakorlója legyen. A szuverenitás értelmezése az idők során folyamatosan változott, talán pontosabb lenne úgy fogalmazni: hogy ha a szuverenitást nem egy normának, hanem sokkal inkább normarendszernek tekintjük, akkor elemei közül a különböző időszakokban más és más került előtérbe. Az bizonyos, hogy a területi főhatalom elvének kizárólagosan államközpontú megközelítése mára erősen megkérdőjeleződött (a nemzetközi területi igazgatás gyakorlata pedig ezen az alapon nehezen is lenne értelmezhető). A szuverenitás „emberközpontúbb” (nép-központúbb) értelmezése felé az elmozdulás a népszövetségi időkben kezdődött (a nemzeti kisebbségek védelme első, intézményesített formában történő elismerésével), s még hangsúlyosabban előtérbe került a dekolonizációs folyamat során, amikor a népszuverenitás kifejeződéseként az önrendelkezési jog nemzetközi védelme felerősödött. (Stahn [2008] p. 755.)

A változás következő hulláma a kilencvenes évekre tehető, amikorra világossá vált: a korábbi, a negatív szuverenitást előtérbe helyező megközelítést végképp felváltotta az a meggyőződés, hogy az államnak két irányban, egyrészt a nemzetközi közösség többi tagja felé, másrészt saját állampolgárai felé is vannak kötelezettségei, s utóbbi egyre nagyobb hangsúlyt kapott. A téma felkerült az ENSZ napirendjére is, ahol Kofi Annan tette fel elsőként a kérdést, hogy vajon az államot vagy az embert illeti-e az elsőbbség akkor, ha a nemzetközi közösség választásra kényszerül. A védelmezés felelösségének (responsibility to protect) koncepciója ${ }^{91}$ is ezt az elmozdulást tükrözi, amelyet egy -

\footnotetext{
${ }^{91}$ A megközelítés lényege, hogy elsődlegesen az állam kötelessége megvédeni a területén élő embereket, $\mathrm{s}$ ha erre nem képes vagy nem hajlandó, akkor a védelmezés felelőssége a nemzetközi közösségre száll, amely szükség esetén dönthet úgy is, hogy a lakosság érdekében beavatkozik a célállamban, amelynek
} 
egyébként a szuverenitás kérdéskörével foglalkozó - kanadai think tank ${ }^{92}$ vetett fel elsőként 2001-ben, az ENSZ pedig az évtized közepétől szintén foglalkozik vele.

A nemzetközi területi adminisztráció tovább „rombolta” a szuverenitás-dogmát amennyiben megkérdőjeleződött az a jogi doktrína, hogy a területi főhatalom csakis az államot illetheti meg -, hiszen gyakorlata során nem-állami szintű entitásokat ruházott fel kiterjedt hatalmi (jellemzően állami) jogosítványokkal. A nemzetközi igazgatási missziók felállítása arra a feltételezésre épül, hogy egy adott entitásnak először meg kell felelnie bizonyos feltételeknek, s csak azután válhat jogosulttá az önkormányzásra vagy a függetlenedésre, erre a jelenségre utal a „kiérdemelt szuverenitás” (earned sovereignty) kifejezés. (Stahn [2008] p. 756.) A kiérdemelt szuverenitás koncepciója alapján háromféle forgatókönyv létezik, az adott terület sajátos körülményei határozzák meg, hogy melyiket kell alkalmazni. A ,szakaszolt szuverenitás" ${ }^{93}$ (phased sovereignty) esetében az adott terület az idők során egyre több hatalmi jogosítványhoz jut hozzá, $s$ így szerzi meg végső státuszát; ha a „feltételes szuverenitás” (conditional sovereignty) által kijelölt úton halad, akkor pedig a státuszrendezést megelőzően meghatározott kritériumokat (pl. emberi jogok, jogállamiság stb.) kell teljesítenie (pl. Koszovó). Azt az esetet, amikor egy egyébként szuverén entitás a jelen levő nemzetközi igazgatási és / vagy katonai missziók által szuverén jogainak gyakorlásában korlátozva van, „korlátozott szuverenitásnak” (constrained sovereignty) nevezzük (pl. BoszniaHercegovina). (Williams-Pecci [2004] p. 20.)

A nemzetközi területi igazgatás kapcsán - és mintegy a gondolat lezárásaként - érdemes még megemlítenünk a Zaum által „szuverenitás-paradoxonnak” nevezett jelenséget, melynek lényege, hogy a nemzetközi területi adminisztráció felállításával a szuverenitást azért korlátozzák, hogy a szuverén állam létrejöhessen. (Zaum [2007] p. 5.)

szuverenitása - s hozzá kapcsolódóan a beavatkozás tilalmának elve is - ilyen módon nyilvánvalóan sérül.

92 ICISS - International Commission on Intervention and State Sovereignty. Az eredeti tanulmány címe: The Responsibility to Protect. Report of the International Commission on Intervention and State Sovereignty.

${ }^{93}$ Példák: Nyugat-Szahara, Kelet-Timor. 


\subsubsection{A szabályozó jogi környezet hiánya}

Szintén problémát jelent a nemzetközi igazgatás esetében, hogy a nemzetközi jogi környezet szegényes a követendő normák tekintetében, s az egyes esetek igen változatos képet mutatnak mind a legitimáció, mind a hatáskörök, mind a szereplök tekintetében, s leginkább az adott konfliktust lezáró nemzetközi szerződések, megállapodások vagy a nemzetközi szervezetek határozatai irányadóak a fenti szempontoknál. Az „alulszabályozás” egyik veszélye abban állhat, hogy bizonyos nemzetközi szereplők egyéni érdekeiknek megfelelően befolyásolják a nemzetközi területi missziók müködését. Persze fel kell, hogy vessük azt a kérdést is, hogy vajon milyen mértékü egységes szabályozás lenne szükséges, arányos és elégséges ahhoz, hogy a nemzetközi területi igazgatási missziók müködésének hatékonysága ne csökkenjen? Fennáll ugyanis a veszélye annak, hogy a túlszabályozás viszont azzal a következménnyel járna, hogy a nagyon széles körben és aprólékosan szabályozó normák rendszere miatt az igazgatott területek sokféleségére és azok egyedi jellegzetességeire, körülményeire képtelen lenne kellö érzékenységgel reagálni a mandátum megalkotója.

Az egységes nemzetközi szabályozás / jogi környezet hiánya jelenti egyfelől a rendelkezésre álló normák alacsony számát, másrészt a meglévők alkalmatlanságát a jelenkori helyzetek szabályozására. A kevés rendelkezésre álló nemzetközi norma, amellyel számolhatunk: az 1907-es hágai konvenció (42-56. cikkek), a negyedik genfi jegyzőkönyv (27-34. és 47-78. cikkek) és az első kiegészítő jegyzőkönyv, valamint a nemzetközi szokásjog egyes elemei. (Wolfrum [2005] p. 651.) A másik súlyos probléma, amint azt fentebb már említettük, hogy a meglévő szabályok nem képesek az egyes helyzetek sajátosságainak megfelelően szabályozni a beavatkozás körülményeit; vegyük sorra a kérdés különböző aspektusait.

Az első probléma a rendelkezésre álló szabályokkal, hogy legalább annyira, de legtöbbször inkább szolgálják a beavatkozó (megszálló) állam érdekeit, mint a célállam állampolgáraiéit. Másodikként említhető, hogy alapvetően a status quo ante helyreállítását célozzák, s többször így maga a nemzetközi beavatkozás jelenti a gátját az egyébként szükséges és időszerü átalakulásnak. Szintén gondot jelent (harmadik), hogy a nemzetközi jelenlét alappilléreként legtöbbször az ENSZ-et jelölik meg, holott ez az univerzálisnak tekinthető nemzetközi szervezet kevéssé alkalmas ilyen feladatok 
ellátására, több ok miatt is. Egyrészt elégtelen nemzetközi jogi megalapozottság hiányában nem képes alkalmazkodni a komplex és egyedi helyzetekhez, másrészt pedig nem rendelkezik megfelelő mandátummal, sőt helyenként még a legitimitása is megkérdőjeleződik. (Wolfrum [2005] pp. 651-652.) Az alapító atyák az ENSZ-et a második világháború végi nemzetközi rendszer követelményeinek és a győztes nagyhatalmak érdekeinek megfelelően, elsősorban a nemzetközi béke és biztonság védelmére hozták létre. Azok a normák, amelyek az ENSZ Alapokmányában vannak lefektetve és a szervezet müködését szabályozzák - legyenek még ma is bármily magasztosak és tiszteletre méltóak - egyben gúzsba is kötik a szervezetet és tehetetlenségre kárhoztatják. Az ENSZ és a nemzetközi közösség számára lehetséges kiútnak a regionális nemzetközi szervezetek bevonása mutatkozik a válságkezelésbe, itt azonban sokadszor szembesülünk az erre vonatkozó nemzetközi szabályozás elégtelen mivoltával.

\subsubsection{A nemzetközi területi adminisztráció legitimitása}

A nemzetközi igazgatás müködése többféle, a legitimitást alátámasztó bázisra helyezhető, alapvetően azonban ezek a források két csoportba sorolhatók. Az első csoportba azok az eljárásjogi (procedurális) aktusok tartoznak, amelyek segítségével valamely szereplő átruházza a hatalmat a nemzetközi adminisztrációra (hozzájárulás, delegálás). A hozzájárulás (consent) a legitimitást biztosító egyik legerősebb forrás (egyben a klasszikus békefenntartás egyik alapköve), amikor a célállam maga kéri a nemzetközi igazgatás alá helyezését, ${ }^{94}$ a delegálás esetében pedig valamely entitás joghatósága felett hatalommal bíró intézmény jogosítványait átruházza - részben vagy egészben delegálja - egy másik intézménynek (a joghatóság ebben az esetben természetesen származékos és sosem teljes). Előfordulhat olyan eset is, amikor a célállam megadta a hozzájárulását, de az igazgatási funkciók delegálása is megtörténik - ebben az esetben a legitimitás jóval erősebb lesz (hisz két forrásból táplálkozik). (Wolfrum [2005] p. 671.)

\footnotetext{
${ }^{94}$ Vannak persze olyan nézetek is, miszerint egy kormányzatnak csak akkor van joga arra, hogy hatalmat gyakoroljon a polgárok közössége felett, ha annak minden egyes tagja hozzájárulását adta ehhez. Ez a feltétel - amely persze nagyon kicsi eséllyel teljesül bárhol is - vonatkoztatható a nemzetközi igazgatásra is, föként, ha az kormányzati funkciókat is gyakorol.
} 
A legitimitást megalapozó elemek második kategóriájába azok a tényezők sorolhatók, amelyeket a nemzetközi közösség olyan alapvető normának tart, amelyeket feltétlenül érvényre kell juttatni, s ez a nemzetközi közösség egészének felelőssége (nemzetközi béke és biztonság védelme, emberi jogok érvényesülése, a kormányzás szükségessége). ${ }^{95}$ (Zaum [2007] p. 58.) Az alábbiakban - alapvetően Zaum modellje nyomán - megvizsgáljuk, hogy a nemzetközi területi igazgatás két példájánál (Bosznia és Koszovó esetében) hogyan érvényesülnek ezek az alapok.

\subsubsection{A boszniai nemzetközi területi igazgatás legitim alapjai}

- Hozzájárulás:

Bosznia esetében a hozzájárulás felsorolható a nemzetközi igazgatás legitim bázisai között, hiszen a daytoni megállapodásban a keretegyezményt aláíró felek elfogadták magukra nézve a dokumentum rendelkezéseit, a nemzetközi polgári és katonai jelenlét Boszniába települését is. ${ }^{96}$ A boszniai nemzetközi adminisztráció elsődleges legitim alapja tehát a daytoni megállapodás.

- Delegálás:

A joghatóság átadása itt nemzetközi szerződéssel történt (daytoni megállapodás), $\mathrm{s}$ nem BT határozaton alapult. Mindazonáltal azon intézmények egy részét, amelyek a boszniai nemzetközi igazgatásban tevékenyen részt vettek, ENSZ BT határozat hozta létre vagy hatalmazta fel (az ENSZ Ao. VII. fejezet alapján) az igazgatás katonai vagy polgári aspektusában való részvételre (pl. az IFOR-t az 1031. sz., az SFOR-t az 1088. sz. BT határozat).

\footnotetext{
${ }^{95}$ Ezek a normák a ius cogens normák közé tartoznak, melyek definíciója az 1963-as, a szerződések jogáról szóló bécsi egyezmény szerint: „az általános nemzetközi jog feltétlen alkalmazást igénylő szabálya olyan normát jelent, amelyet az államok nemzetközi közössége, mint egész, olyanként fogadott el és ismert el, mint amelytöl nem lehet eltérni és amelyet csak a nemzetközi jognak az ugyanilyen jellegü későbbi szabályával lehet megváltoztatni.” (Bécsi egyezmény [1963] 53. cikk)

${ }^{96}$ Két ponton inog meg a hozzájárulás mint legitimáló tényező: az egyik, hogy a keretmegállapodást nem a boszniai szerbek és a boszniai horvátok írták alá, hanem Horvátország és Szerbia politikai vezetői, $\mathrm{s}$ ezért nagy valószínűséggel nem állítható, hogy minden érintett fél hozzájárulása adott volt az aláiráskor. A másik tényező, hogy a daytoni megállapodás ugyan rögzítette a fömegbízott pozícióját és szerepét, az idők során azonban jelentősen kibővítették a mandátumát, ezt pedig a Biztonsági Tanács hagyta jóvá, $\mathrm{s}$ nem egy, az érintett helyi szereplők által aláírt szerződésben rögzítették a változtatásokat. (Zaum [2007] pp. 59-60.)
} 
- Nemzetközi béke és biztonság megőrzése:

A boszniai háború 1992 és 1995 között - és a párhuzamosan 1991-től Horvátországban és rövid ideig 1991-ben Szlovéniában zajló háborúkkal együtt nemcsak az ország és szomszédai, de az egész Balkán stabilitását veszélyeztette és súlyos következményekkel járt Európa többi államára nézve is (instabil környezet, migráció stb.). Az ENSZ BT több határozatában hivatkozott a válság nemzetközi békét és biztonságot veszélyeztető hatására, ami megalapozza a VII. fejezet alapján történő intézkedést.

- Emberi jogok és demokratizálódás:

A délszláv válság során - főként Boszniában - a lakosság jelentős hányada elszenvedte a humanitárius jogsértések valamely formáját, az etnikai tisztogatás mindennapos volt, a háború során közel százezren meghaltak, a külső és belső menekültek száma pedig több százezerre tehető. A humanitárius katasztrófa megalapozta már a háború alatt is az ENSZ BT kényszerintézkedéseit, a rendezés során pedig nagy hangsúlyt kaptak az emberi jogokkal kapcsolatos rendelkezések. A daytoni megállapodás tételesen felsorolja az alapvető emberi jogokat és szabadságokat, s rendelkezik az alapvető emberi jogi intézmények létrehozásáról is, az alkotmány pedig felsorolja azokat a nemzetközi emberi jogi egyezményeket is, melyekben Bosznia részes állam. (Daytoni megállapodás [1995] 6. sz. és 4. sz. mellékletek) Ami a demokratizálódást illeti, a nemzetközi területi adminisztrációk, pontosabban a kereteik közt tevékenykedő nemzetközi szervezetek egyaránt vallják a liberális demokrácia univerzalizmusát, s tevékenységükkel és eszközeikkel igyekeznek ezt megalapozni. (Csicsmann [2006] pp. 51-54.)

- Kormányzás:

A háború lezárását követően Boszniában felálltak az alkotmányban rögzített központi és decentralizált szervek, ám elsősorban a súlyos politikai-etnikai polarizáció következtében az állam müködtetése nagy nehézségekbe ütközött, a nemzetközi közösség támogatását igényelte, s szükségessé tette ideiglenesen bizonyos kormányzati jogkörök átvételét. A polgári igazgatás vezetőjét végrehajtó jogosultságokkal ruházták fel (s ezek körét az idők során még ki is bővítették). ${ }^{97}$

\footnotetext{
${ }^{97}$ A nemzetközi igazgatással és jogosítványaival részletesen foglalkozik a boszniai esettanulmány a 2 . fejezetben.
} 


\subsubsection{Legitimitás a koszovói igazgatásnál}

- Hozzájárulás:

Koszovónál a hozzájárulás csak közvetett formájában létezik, de érdemes megemlíteni. Az 1998-1999-es háborút lezáró rendező dokumentum az 1244-es BT határozat, amelynek elfogadását közvetlenül megelőzte a kumanovói katonaitechnikai megállapodás aláírása (ebben jelenik meg a hozzájárulás motívuma). ${ }^{98} \mathrm{~A}$ dokumentum azonban nem konszenzuson alapult, hiszen a szerbek írták alá, akiknek szuverén jogai a koszovói tartomány felett megszüntek az 1244-es BT határozat elfogadásával, ráadásul a kumanovói megállapodás aláírói között nem voltak ott a koszovói lakosok kilenc tizedét kitevő albánok - a közvetettséget ez indokolja.

- Delegálás:

Nemzetközi szerződés hiányában az ENSZ Biztonsági Tanácsa 1244. sz. határozatával ruházta a koszovói nemzetközi adminisztrációra a Koszovó feletti joghatóságot az ENSZ Alapokmányának VII. fejezete alapján, mely lehetőséget ad a BT számára, hogy a nemzetközi béke és biztonság veszélyeztetése esetén lépéseket - akár fegyveres kényszerintézkedést - foganatosítson. Az ENSZ Alapokmány szerint (41. cikk [1945]) a BT-nek jogában áll fegyveres erő felhasználásával nem járó egyéb intézkedéseket tenni, így akár egy adott terület felett átvállalni a kormányzati jogokat, vagy azokat átadni egy másik nemzetközi szervezetnek vagy államok egy csoportjának. (Wolfrum [2005] p. 669.) Az ENSZ-tagállamok - így a Jugoszláv Szövetségi Köztársaság is - a szervezethez való csatlakozáskor ezen rendelkezéseket és az azokból fakadó jogokat és következményeket magukra nézve elfogadták. A koszovói nemzetközi igazgatás elsődleges legitim bázisa az 1244-es BT-határozat. ${ }^{99}$

- Nemzetközi béke és biztonság megörzése:

A koszovói válság háborús szakasza 1998-1999-ben a JSzK és annak tartománya, Koszovó közt zajlott, de potenciális destabilizáló hatásával veszélyeztette az egész

\footnotetext{
${ }^{98}$ A megállapodás a NATO és a Jugoszláv Szövetségi Köztársaság (Slobodan Milošević képviseletében) közti szerződés, amelyben a szerbek elfogadják, hogy Koszovóba nemzetközi katonai és polgári erők települnek, amelyről részletesen rendelkezik egy BT határozat (ez lesz az egy nappal később elfogadott 1244-es). (Kumanovói megállapodás [1999])

${ }^{99}$ A delegálás esetében is felvethető az az aggály, hogy a nemzetközi közösség egésze nem áll a hatáskörátruházás jogi aktusa mögött, hiszen a BT-ben csak 15 állam szavaz, ráadásul a kettős vétó intézménye révén az öt állandó tag megkerülhetetlen egy határozat elfogadásához.
} 
térség biztonságát, így a BT joggal hivatkozott ebben az esetben is a béke és biztonság megsértésére.

- Emberi jogok és demokratizálódás:

A koszovói válságot a nemzetközi közösség humanitárius katasztrófaként értékelte, amelynek során több százezer - zömmel koszovói albán - menekült a tartományon belül, a szomszédos országokba vagy Európa más országaiba. Az 1244-es BT határozat síkra szállt az emberi jogok védelméért, kiemelte a menekültek visszatérésének fontosságát, ennél részletesebben azonban nem taglalta a témát. A nemzetközi adminisztráció polgári részét összefogó UNMIK első rendelete azonban pótolta ezt a hiányosságot. ${ }^{100}$ (UNMIK/REG/1999/1, 1. rész)

- Kormányzás:

1999 nyarán a rendezés következményeként megszünt Szerbia szuverenitása a koszovói tartomány felett, ${ }^{101} \mathrm{~s}$ a kormányzati funkciók ellátását teljes egészében a nemzetközi közösség vállalta át. Fontos, hogy a nemzetközi adminisztráció mindig csak átmeneti jelleggel szabad, hogy átvállalja a kormányzati hatáskörök gyakorlását, hiszen a háború sújtotta államok esetében a cél az önrendelkezési jog gyakorlásának „visszaadása” a helyi közösségek számára, amint az lehetséges. A nemzetközi területi adminisztrációnak tehát célja a demokratizálás, de legitimitását éppen az áshatja alá, hogy az önrendelkezést akadályozza. (Zaum [2007] p. 65.)

\subsubsection{A nemzetközi területi adminisztráció elszámoltathatósága}

Bármely politika rendszer demokratikus müködésének alappillére az elszámoltathatóság. A nemzetközi területi igazgatás esetében viszont az a sajátos helyzet áll fenn, hogy amíg a nemzetközi igazgatás létezésének egyik legfontosabb célja a demokratikus intézményrendszer megteremtése a célállamban, addig önmaga súlyos

\footnotetext{
100 „Minden Koszovóban közfeladatot ellátó vagy közhivatalt betöltő személy, miközben ellátja feladatát, tekintettel kell, hogy legyen a nemzetközileg elfogadott emberi jogi sztenderdekre és senkire vonatkozóan nem tesz semmilyen, nemen, fajon, bőrszínen, nyelven, valláson, politikai vagy más nézeteken, nemzeti, etnikai vagy társadalmi hovatartozáson, nemzeti közösséghez kötődésen, tulajdonon, születésen vagy más státuszon alapuló hátrányos megkülönböztetést.” (UNMIK/REG/1999/1, 1. rész)

${ }^{101}$ A szerbek kivonulása Koszovóból azért is bizonyult végzetesnek az állam működését tekintve, mert ahogy a nyolcvanas évektöl egyre romlott a viszony az albánok és a szerbek között (föként a koszovói autonómia 1989-es visszavonását követően), úgy az állami intézményekböl is fokozatosan egyre inkább kiszorultak az albán nemzetiségűek, s helyüket szerb tisztségviselők töltötték be. Amikor a koszovói háború befejeződött, a szerb állami hivatalnokok és alkalmazottak jelentős része elhagyta az országot, a megfelelő étszámú és képzettségü helyi szakembergárda hiánya pedig súlyos kapacitás-problémákat okozott.
} 
deficitekkel küzd ezen a területen. A nemzetközi adminisztráció tulajdonsága, hogy eltérő térbeli identitása elválasztja attól a társadalomtól, amely felett kormányzati jogokat gyakorol, létrehozása pedig egy nemzetközi szervezet jogi aktusával történik, nem pedig célállam helyi közösségének választása útján. (Zaum [2007] p. 67.)

Az elszámoltathatóság két irányban lehetséges és szükséges: egyrészt a küldő szervezet felé, ez esetben azon nemzetközi intézmény(ek) irányába, amelyek létrehozták a szóban forgó nemzetközi területi igazgatást, vagyis ahonnan annak mandátuma ered (ez az ún. belső elszámoltathatóság). Az elszámoltathatóság másik iránya azon társadalom felé mutat, amelyben az adott igazgatási struktúra tevékenykedik, ez esetben ez a célállamok társadalma (ez az ún. demokratikus elszámoltathatóság). Utóbbi lényegében az intézkedések és a döntések által érintett személyek azon joga, hogy megújítsák, visszavonják vagy felülvizsgálják a hatalomgyakorlók mandátumát. (Sklar [1999] p. 54.) A nemzetközi területi igazgatások esetében beszélhetünk belső elszámoltathatóságról, hiszen mindenütt jellemző a létrehozó nemzetközi szervezet irányában fennálló beszámolási kötelezettség. Ami a demokratikus elszámoltathatóságot illeti, az a nemzetközi területi igazgatás modelljeiböl hiányzik. (Wolfrum [2005] p. 685.)

Világosan kell látnunk, hogy ez a kérdés miért különösen jelentős a területi igazgatások gyakorlatában: minél több jogosítvánnyal rendelkezik ugyanis az adott adminisztratív struktúra (néhol az állami müködéshez kapcsolódó jogok szinte teljes spektrumával bír), annál nagyobb az elszámoltathatóság miatt fennálló demokratikus deficit. A nemzetközi területi igazgatás alkalmazottait megilletik azok - a nemzetközi kapcsolatokban egyébként teljesen általános gyakorlatként alkalmazott - a kiváltságok és mentességek, amelyekkel felvértezve a munkájuk során végzett tevékenységek kapcsán teljes, magánéletükben pedig korlátozott immunitás illeti meg őket, azaz a helyi bírói szervek előtt nem vonhatók felelősségre tetteikért.

Ennek több következménye van. Egyrészt a demokratikus felelősségre vonás hiánya azért aggályos, mert a nemzetközi közösségnek a nemzetközi területi igazgatás felállításával éppen az volt a célja, hogy a demokratikus politikai intézményeket létrehozza, és ezáltal megteremtse a demokratikus jogállam pilléreit. Ha nincs mód az elszámoltathatóságra, akkor az rossz precedenst teremt a helyi politikusoknak, s akár alá 
is áshatja a demokrácia megteremtéséhez vezető tranzíciós folyamatot. Ugyanakkor látnunk kell, hogy az elsődleges ok, amiért a nemzetközi közösség a területi adminisztrációt a helyszínre telepítette, az az, hogy előmozdítsa az önkormányzást, ami egyébként nem lenne lehetséges a konfliktus lezárása után a nemzetközi szerepvállalás nélkül, hiszen a legitim helyi politikai intézmények ekkor még hiányoznak. (Zaum [2007] p. 68.) Ezt a dilemmát nem tudjuk feloldani, így megállapíthatjuk, hogy a demokratikus elszámoltathatóság nehezen összeegyeztethető a nemzetközi területi igazgatás mandátumával. Főként igaz ez a nemzetközi területi igazgatás müködésének kezdetén, Chesterman azonban úgy érvel, hogy ha a politikai környezet normalizálódik, s a demokratikus intézményépítés egy bizonyos szakaszba ér, érdemes létrehozni azokat a mechanizmusokat, amelyek révén a nemzetközi jelenlét elszámoltatható. Ez hozzájárulna a jogállamiságon és az emberi jogok tiszteletén alapuló politika kultúra meggyökeresedéséhez, s növelné a helyiek részéröl megnyilvánuló bizalmat a nemzetközi szereplök felé. (Chesterman [2004] p. 153.)

A balkáni példákat vizsgálva Boszniában a nemzetközi szerepvállalás sokszor éppen a főmegbízott (OHR) felelősségre vonásának hiányából fakadó demokratikus deficit miatt kerül a kritikák kereszttüzébe. A fömegbízott ugyanis igen kiterjedt jogokkal rendelkezik, jogszabályokat semmisíthet meg, demokratikusan megválasztott politikusokat, magas rangú tisztségviselőket bocsáthat el hivatalukból. Ami az elszámoltathatóságot illeti, az OHR a Biztonsági Tanácsnak, az Európai Parlamentnek és a Békevégrehajtó Tanácsnak (PIC) ${ }^{102}$ rendszeres idöközönként beszámol munkájáról és annak eredményeiről. Az elszámoltathatóság ezen belső aspektusa tehát adott és létező, sőt azt mondhatjuk, hogy kifejezetten tág azon nemzetközi szereplők és intézmények köre, amelyek ellenőrzik az OHR munkáját. A vertikális elszámoltathatóság (a boszniai társadalom felé) azonban nagyrészt hiányzik; az ügyben precedens-értékü a boszniai alkotmánybíróság 2000-es döntése, ${ }^{103}$ amelynek következményeként az OHR egyes döntéseit vizsgálhatja az $\mathrm{AB}$, de a boszniai tisztségviselők és a politikai mandátummal rendelkező szereplők elbocsátása ügyében hozott OHR-határozatokra nem terjed ki az $\mathrm{AB}$ ezen joga. A legnagyobb problémát

\footnotetext{
${ }^{102}$ Tekintve, hogy a Békevégrehajtó Tanács 2000 óta nem ült össze, az OHR valójában a PIC szűkebb körű, végrehajtó szervként funkcionáló Kormányzótanácsának (Steering Board) jelent, ennek tagjai a G8ak, Törökország, az Európai Unió elnöksége, az Európai Bizottság, és Törökország (az Iszlám Konferencia Szervezetének képviseletében).

${ }^{103}$ A hivatkozott alkotmánybírósági döntés: Constitutional Court of Bosnia and Hercegovina, Decision No. U 9/00, 3 November 2000.
} 
ezzel kapcsolatban az jelenti, hogy semmilyen jogorvoslati fórum nem állt a „,sértettek” rendelkezésére, ahol panasszal élhetnének az OHR eljárása ellen. Itt pedig megint a demokratikus müködés egy újabb pillérének (a jogorvoslat biztosításának) hiányáról van szó, s ugyanakkor megvalósul az emberi jogok sérelme is.

A koszovói helyzetet tekintve az UNMIK az ENSZ föszervei felé beszámolási kötelezettséggel tartozik: a Biztonsági Tanácsnak rendszeres időközönként jelentéseket ad le, a Titkárság pedig bürokratikus felügyeletet gyakorol felette, a koszovói intézmények azonban nem vonhatják felelösségre az UNMIK alkalmazásában álló nemzetközi tisztségviselöket.

Minden Boszniában, mind pedig Koszovóban vannak ugyan ombudsmanok, akiknek legfőbb feladata, hogy őrködjenek az emberi jogok érvényesülése felett. Boszniában az ombudsmannál csak helyi intézményt lehet bepanaszolni, Koszovóban a KFOR-erők ellen nem lehet panasszal élni, mint ahogyan a koszovói ombudsman nem vizsgálhatja az UNMIK és annak egy alkalmazottja közti vitás helyzeteket se. (Chesterman [2004] p. 147.) Az UNMIK ellen fordulhatnak a koszovói állampolgárok az ombudsmanhoz, aki azonban csak ajánlás jellegü állásfoglalásokat tehet. (Wolfrum [2005] p. 686.) 


\section{NEMZETKÖZI TERÜLETI IGAZGATÁS BOSZNIA- HERCEGOVINÁBAN}

\subsection{Bosznia-Hercegovina a daytoni megállapodás elfogadás után}

Az 1991 nyara óta tartó és három balkáni országban zajló háború lezárása a daytoni megállapodással történt. A béketárgyalások az egyesült államokbeli, ohiói WrightPatterson légibázison - a külvilágtól szigorúan elzárva - zajlottak 1995 novemberében 21-ig. A dokumentum - melynek hivatalos neve: Általános keretegyezmény a békéről Bosznia-Hercegovinában (The General Framework Agreement for Peace in Bosnia and Herzegovina), a továbbiakban: daytoni megállapodás vagy keretegyezmény ${ }^{104}$ aláírására ünnepélyes keretek között Párizsban került sor 1995. december 14-én. (Juhász [1999] p. 274.) A dokumentum jelentősége mindenekelött abban áll, hogy a poszthidegháborús időszak nemzetközi területi adminisztrációi közül az egyik első igazán nagyszabású vállalkozást megalapozó dokumentumnak tekinthető.

A daytoni megállapodás elfogadása pillanatától kritikák célpontja. Ez a tény önmagában még nem meglepő, hiszen kevés békemegállapodás szolgált az érintett felek mindegyikének egyforma megelégedésére. Az kétségtelen tény, hogy a daytoni megállapodás éppen azoktól a kompromisszumoktól „terhes”, amelyek egyrészt a háborúban érintett felek (szerbek, horvátok és bosnyákok), másrészt pedig a közvetítésben legaktívabb nemzetközi aktorok érdekeinek eredőjeként születtek. A megállapodás rendelkezései annak a legkisebb közös többszörösnek tekinthetőek, amely még elfogadható volt a felek számára. Az aláírás pillanatában, a négyéves háború után, az volt a legfontosabb, hogy végre befejeződjön a megközelítőleg százezer halálos áldozattal járó véres konfliktus - nem tünt akkor megfizethetetlenül nagy árnak a felek különböző érdekeinek kielégítése.

\footnotetext{
${ }^{104}$ A daytoni megállapodás (The General Framework Agreement for Peace in Bosnia and Herzegovina) teljes szövegét lásd az OHR honlapján. (www.ohr.int)
} 
A daytoni megállapodásról bebizonyosodott az idők során, hogy olyan struktúrát vizionált, amely nem alkalmas arra, hogy megalapozza Bosznia-Hercegovina etnikumainak együttélését és arra sem, hogy megfelelően rendezze az állam sorsát hosszabb távon. A legnagyobb probléma azonban nem elsősorban a dokumentum tartalmából és konkrét rendelkezéseiből fakad, hanem abból a tényből, hogy a Daytonban vázolt (nem megfelelő) struktúra túlságosan hosszú - pillanatnyilag beláthatatlan, hogy pontosan mennyi - ideig löki tovább Boszniát azon az úton, amely a boszniai nép számára nyilvánvalóan nem elöre, a fejlödés irányába tart, hanem leginkább sehová. Arra pedig, hogy a megállapodást egy alkalmasabb, hasonló súlyú nemzetközi szerződéssel váltsák fel, vajmi kevés esély mutatkozik, mert a kompromisszumkészség meglehetősen csekély mind az államalkotó etnikumok, mind pedig a balkáni stabilizációban érdekelt felek között.

\subsubsection{A nemzetközi igazgatás jogi alapja: daytoni megállapodás}

A dokumentum rendelkezéseit olvasva szembetűnő, hogy a daytoni megállapodás szellemisége ugyanazokra az elvekre épült, amelyek a nemzetközi közösség háború alatti béketerveiben is nyilvánvalóan jelen voltak, nevezetesen: 1) a területi integritáshoz és a határok sérthetetlenségéhez történő ragaszkodás, vagyis az állam nemzetközi határai a korábbi jugoszláv belső, adminisztratív határok lettek; ${ }^{105}$ és 2) az etnikai alapú politikai hatalomgyakorlás: abból kiindulva, hogy a délszláv válság okai a nemzetközi aktorok nagy része szerint túlnyomórészt az etnikai szembenállásból fakadtak, az új államszerkezet meghatározásakor a legfontosabb elv az etnikai paritás alkalmazása volt annak érdekében, hogy az etnikumok közötti további konfliktusoknak elejét vegyék.

105 Ez a meggyőződés az 1991-ben - a jugoszláv széthullás nemzetközi jogi problémáinak megválaszolására - létrehozott tanácsadó testület, a Badinter Bizottság 2-es és 3-as számú véleményeiben jelent meg elsőként. A 3. számú (1991. nov. 20-i) véleményében a Bizottság kimondta, hogy a határok tekintetében az uti possidetis iuris elv alapján a függetlenedés pillanatában érvényes határok, vagyis a korábbi jugoszláv belső, ún. adminisztratív határok válnak nemzetközi határokká. A 2. számú véleményben (szintén 1991. november 20.) közvetett módon jelenik meg a határok sérthetetlenségének elve, méghozzá az önrendelkezéssel összefüggésben, amennyiben ott kimondták, hogy az önrendelkezés jogának gyakorlása semmiképpen sem járhat a határok megváltoztatásával. (Pellet [1992] p. 180.) (A forrásként megjelölt dokumentum tartalmazza a Badinter Bizottság véleményeit mellékletként teljes terjedelemben angol nyelven.) 
A daytoni megállapodás egy, az általános elveket tartalmazó keretmegállapodásból és a konkrét rendelkezéseket magukba foglaló mellékletekből áll, utóbbiak mindegyike önálló nemzetközi szerződésnek minősül. ${ }^{106}$

A daytoni megállapodás - a békeszerződésekre jellemző módon - rendelkezik a háború lezárásáról, különlegessége azonban abban áll, hogy egyrészt egyik melléklete BoszniaHercegovina új alkotmánya, másrészt pedig kijelöli a Boszniában felállítandó nemzetközi igazgatás alapvető szerkezetét és meghatározza az abban részt vevő nemzetközi szervezetek feladatait. Az alábbiakban röviden ismertetjük és értékeljük a békemegállapodás mellékleteinek tartalmát a dokumentum hiteles szövege alapján. Az itt használt tematikus rendezés nem felel meg a mellékletek sorrendiségének és eredeti szerkezetének, viszont mindegyik vizsgált dimenzió esetében egyfajta kiindulópontként szolgál a daytoni megállapodás szövege és mindenütt jelöljük az adott témára vonatkozó rendelkezések helyét a békedokumentumban. A „kiindulásként szolgáló alapok" ily módon történő ismertetését követően az egyes dimenzióknál felvázoljuk a legfontosabb történéseket és fejlődési irányokat a háború lezárása óta, majd külön tárgyaljuk mindenütt a nemzetközi szerepvállalást. Minden egyes vizsgált témakör összefoglaló résszel zárul.

\subsubsection{A boszniai állam felépítése és müködése 1995 után}

Ebben a fejezetben arra törekszünk, hogy bemutassuk a boszniai állam és az államrészek (entitások) felépítését, valamint az egyes közigazgatási szintekhez rendelt jogosítványokat és intézményeket. A daytoni megállapodás alábbi fejezetei a leginkább relevánsak a téma szempontjából: ${ }^{107}$

- 2. sz. melléklet: Megállapodás az entitásközi határvonalról és az ehhez kapcsolódó kérdésekről

- 4. sz. melléklet: Bosznia-Hercegovina alkotmánya

- 5. sz. melléklet: Megállapodás a viták rendezéséről (Agreement on Arbitration)

\footnotetext{
106 A keretmegállapodás aláírói a balkáni térségből Alija Izetbegović boszniai, Slobodan Milošević szerbiai és Franjo Tuđman horvátországi államelnökök, valamint tanúként - a nemzetközi közösség képviseletében - az Európai Unió, Franciaország, Németország, Oroszország, az Egyesült Királyság és az Amerikai Egyesült Államok képviselői voltak.

${ }^{107}$ A keretegyezmény többi fejezetének rendelkezéseit a további, tematikus fejezetekben tekintjük át.
} 
- 8. sz. melléklet: A nemzeti emlékhelyek védelmével foglalkozó bizottságról szóló megállapodás

- 9. sz. melléklet: Bosznia-Hercegovina közüzemi szolgáltatóinak alapításáról szóló megállapodás

Részletesebben a továbbiakban a vizsgálat szempontjából legfontosabb 2. és 4. számú melléklettel foglalkozunk, elsőként a központi (szövetségi) szintet ismertetjük, majd bemutatjuk az egyes államrészeket is. ${ }^{108}$ Utóbbira csupán rövid terjedelemben vállalkozunk, hiszen a nemzetközi közösségnek itt és az alsóbb igazgatási szinteken (kantonok, önkormányzatok) jellemzően nem akad tennivalója.

A 2. számú melléklet: az államalkotó entitások, vagyis a Bosznia-hercegovinai Föderáció (Federacija Bosne i Hercegovine, a továbbiakban Föderáció) és a Republika Srpska (a továbbiakban RS) között húzódó határról (ún. entitásközi határról) rendelkezik. A megállapodás értelmében a Föderáció az állam területének 51\%-án, a Republika Srpska pedig az állam területének 49\%-án helyezkedik el. (Daytoni megállapodás [1995] 2. sz. melléklet)

A két államalkotó résznek juttatott területek nagyságát sok kritika érte. Nyilvánvaló ugyan az a szándék, hogy a RS - amely a nemzetközi közösség szerint agresszív expanzionizmusa okán a konfliktus legfőbb okozója volt, és amely a háború során 1992re Bosznia egész területének csaknem kétharmadát ellenőrzése alá vonta semmiképpen ne kapja meg az állam területének többségét. Az entitásközi határok daytoni megállapítása azonban mégis lényegében elismerte a szerbek háború alatti területszerzésének zömét. Így az az igen súlyos vád is felvethető a daytoni rendezés

108 A daytoni megállapodás több mellékletével nem foglalkozunk részletesen a dolgozatban, ezek lényegét itt foglaljuk össze röviden.

Az 5. számú melléklet az entitásokat kötelezi a köztük fennálló vitás kérdések döntőbíróság útján történő rendezésére.

A 8. számú melléklet a nemzeti emlékhelyek megörzéséért felelős testület (Commission to Preserve National Monuments) létrehozásáról rendelkezik, amelynek két tagját (köztük az elnökét is) az ENSZ Nevelésügyi, Tudományos és Kulturális Szervezete (United Nations Educational, Scientific and Cultural Organization - UNESCO) föigazgatója nevezi ki. A tagok megbízatása öt évre szólt, és megújítható volt. A nemzetközi irányítás öt éves átmeneti időszakot követően megszünt ezen a területen, $\mathrm{s}$ a boszniai kormány kezébe került.

A 9. számú melléklet a boszniai közüzemi szolgáltatók létrehozásáról határoz, ami a súlyos anyagi károkat elszenvedett ország esetében a mindennapi élet normális menetéhez szükséges sürgös lépés volt az áram-, a víz-, és az energiaellátás, a postai és a kommunikációs szolgáltatások és a közlekedés területén. A daytoni megállapodás rendelkezett legföbb koordináló szervként a Közellátási Bizottság (Commission on Public Corporations) létrehozásáról, melynek öt tagja közül kettő nemzetközi, kijelölésük az Európai Újjáépítési és Fejlesztési Bank feladata volt. (Daytoni megállapodás [1995]) 
kapcsán - még akkor is, ha újfent elismerjük: alternatívák hiányában más lehetősége a nemzetközi közösségnek a háború lezárásakor nem volt -, hogy az 1995-ös állapotok rögzítésével a keretegyezmény valójában az etnikai tisztogatás eredményét legitimálta.

A boszniai közigazgatás négyszintü, ez a Föderáció és az RS különböző felépítéséből adódik. Amíg ugyanis a Republika Srpska nem tagolódik kisebb igazgatási egységekre, ${ }^{109}$ hanem önkormányzatokból áll, addig a Föderációt tíz kanton alkotja, ${ }^{110}$ amelyek számos önálló jogkörrel rendelkeznek, s az igazgatási struktúra harmadik szintjét alkotva „beékelődnek” a tagállami és az önkormányzati szintek közé.

\subsubsection{Bosznia-Hercegovina alkotmánya, az állam fontosabb törvényhozó, végrehajtó és birói szervei}

A daytoni megállapodás 4. számú melléklete - a szuverén államok esetében meglehetősen sajátos módon - Bosznia-Hercegovina új alkotmánya. Mint minden alaptörvény, ez is rendelkezik az állam felépítéséről, szimbólumairól, fővárosáról (Szarajevó), a tényezők szabad áramlásáról, az állam demokratikus voltáról és a demokratikus elvekről, valamint az állampolgárságról. (Daytoni megállapodás [1995] 4. sz. melléklet)

Az alkotmány tételesen felsorolja, hogy mely területek tartoznak a szövetségi állami hatáskörbe, s melyek képezik az egyes entitások felelősségi területét. Ennek alapján kirajzolódik egy meglehetősen gyenge szövetségi állam és egy, az entitásokat előtérbe helyező decentralizált struktúra. A központi (szövetségi) állami irányítású területek a következők: külpolitika; külkereskedelem-politika; vámpolitika; monetáris politika; nemzetközi intézmények és kötelezettségek finanszírozása; menekültügyi és bevándorláspolitika és -szabályozás; a nemzetközi és entitásközi büntetőjog kikényszerítése, ideértve a kapcsolatokat az Interpollal is; közös és nemzetközi kommunikációs eszközök alapítása és müködtetése; entitásközi szállítás szabályozása;

\footnotetext{
${ }^{109}$ Érdemes megjegyezni, hogy a RS-ban valójában léteznek az önkormányzatoknál nagyobb egységek, ezek a régiók, amelyek azonban - ellentétben a föderációbeli kantonokkal - nem tekinthetőek önálló igazgatási szintnek.

${ }^{110}$ A tíz kanton a következö: 1. Una-Sana, 2. Szávamellék, 3. Tuzla, 4. Zenica-Doboj, 5. Boszniai Drinamente, 6. Közép-boszniai, 7. Hercegovinai-Neretvai, 8. Észak-Hercegovinai, 9. Szarajevói, 10. 10es (vagy Livnói). Forrás: Bosznia-hercegovinai Föderáció parlamentje http://www.parlamentfbih.gov.ba (letöltés: 2011.11.21)
} 
légi forgalom ellenőrzése. (Daytoni megállapodás [1995] 2. sz. melléklet, III./1. cikk) Ezeken a zömmel klasszikusnak mondható területeken kívül minden kérdésben az entitások, vagyis a Föderáció és a RS dönthet.

A központi (szövetségi) állami intézményekről is rendelkezik az alkotmány, ezek: a kétkamarás parlament, az elnökség, a minisztertanács (a tulajdonképpeni kormány), az alkotmánybíróság és a központi bank. A szövetségi parlament 15 tagú felsőháza a Népek Háza (Dom naroda), 42 tagú alsóháza pedig a Képviselök Háza (Prestavnički dom), mindkettőben a képviselői helyek kétharmada a Föderációt (fele-fele arányban a bosnyákokat és a boszniai horvátokat), egyharmada pedig az RS-t (a szerb etnikum tagjait) illeti meg. (Daytoni megállapodás [1995] 2. sz. melléklet, IV. cikk)

A háromfős államelnökséget (predsjedništvo) (egy bosnyák, egy horvát és egy szerb taggal) közvetlenül választják az állampolgárok, a tagok négy évre látják el az államfői tisztet, egyszer újraválaszthatók (ezt követően négy évig nem jelölhetők), s konszenzussal döntenek az egyes ügyekről. Az elnökség bosnyák és horvát tagját a Föderációban, a szerb tagot pedig a Republika Srpskában választják a választásra jogosult állampolgárok. (Daytoni megállapodás [1995] 2. sz. melléklet, V. cikk) A három tag közül az elnök választásáról a szövetségi parlament dönt, a poszton nyolchavonta váltják egymást a tagok. ${ }^{111}$ (Šelo Šabić [2005] p. 194.) Mind az államfői, mind a törvényhozói hatalmat korlátozza egyfajta kvázi vétójog, amely arra ad lehetőséget a három etnikum mindegyikének, hogy az adott népcsoport vitális érdekeire hivatkozva elutasítson egy adott jogszabály-tervezetet. Ezzel a lehetőséggel igen gyakran éltek (élnek) és visszaélnek a boszniai politikusok, egyik legjelentősebb akadályát képezve ezzel az állam hatékony müködésének.

A boszniai szövetségi intézmények sorában meg kell említeni a minisztertanácsot (vijeće minstara), a tulajdonképpeni kormányt. A daytoni megállapodás elfogadása óta a kabinet ment keresztül a legtöbb változáson. Ám köszönhetően a boszniai etnikumok (főként a szerbek) körében az erős szövetségi intézmények kialakítása irányában tapasztalható heves ellenállásnak, és az ennek eredményeként megvalósított erős decentralizációnak, - a közigazgatás alsóbb szintjeinek nagyfokú önállósága miatt - ma

\footnotetext{
${ }^{111}$ Az államelnökség jelenlegi tagjai: Bakir Izetbegović (bosnyák), Nebojša Radmanović (szerb), Željko Komšić (horvát). Közülük a soros elnök most Izetbegović. (Bosznia-hercegovinai Elnökség [é. n.])
} 
is ez tekinthető a „leggyengébb” szövetségi szervnek. (Šelo Šabić [2005] p. 199.) A minisztertanács a békeszerződés értelmében 1995-ben még csupán három tárcával jött létre, ${ }^{112}$ ez a szám mára kilencre emelkedett, ${ }^{113}$ (Bosznia-hercegovinai Minisztertanács [2012]) bizonyítva, hogy az idők során a központi kormányzat megerősödésének helyesebb azt írni az erős nemzetközi nyomás miatt, hogy: megerősítésének - vagyunk tanúi. ${ }^{114}$ Fontos változás volt az is, hogy a minisztertanács elnöksége az új törvényi szabályozás értelmében nem rotál a tagok között, ${ }^{115}$ az a kikötés viszont megmaradt, hogy a kormányfő nem lehet azonos nemzetiségü az államelnökkel, mint ahogyan a kormányfó és a miniszterek helyetteseinek is más etnikumhoz kell tartozniuk, mint elöljárójuk. (Šelo Šabić [2005] p. 200.) Hasonlóan a többi parlamentáris demokráciához, munkájáról a kormány Boszniában is a parlamentnek tartozik beszámolási kötelezettséggel.

Az etnikai arányosság - hasonlóan az eddig felsorolt állami intézményekhez - a kilenctagú Alkotmánybíróság (ustavni sud) esetében is érvényesül. Az alkotmánybíróság tagjai hivataluk első ciklusában öt évig, a második ciklustól kezdve viszont 70 éves korukig tölthetik be tisztségüket, mandátumuk utóbbi esetben tehát már nem határozott időre szól. (Daytoni megállapodás [1995] 4. sz. melléklet VI/1. cikk)

Számunkra azonban, akik elsősorban a nemzetközi közösség szerepvállalására koncentrálunk, különösen érdekes az, hogy az állam felépítése kapcsán milyen hatásköröket rendel a dokumentum a nemzetközi aktorokhoz. Általánosságban elmondható, hogy a daytoni megállapodás rendelkezései alapján néhány intézmény esetében öt-hat éves átmeneti periódust követően tették lehetővé, hogy az adott terület irányítását a boszniai polgárok teljes mértékben a kezükbe vegyék, addig azonban különféle korlátozásokkal és bizonyos fokú nemzetközi jelenléttel is számolniuk kell.

\footnotetext{
${ }^{112}$ A minisztertanács gyenge mivoltát bizonyítja az is, hogy a daytoni megállapodásban még csak nem is külön cikkben rendelkeznek róla, hanem az elnökségröl szóló V. cikkben. (Daytoni megállapodás [1995] 2. sz. melléklet, V/4. cikk)

${ }^{113}$ A boszniai minisztériumok a következök: külügyi, biztonsági, védelmi, pénzügyi, igazságügyi, külkereskedelmi és gazdasági kapcsolatokkal foglalkozó, kommunikációs és közlekedési, emberi jogi és menekültügyi, civil ügyeket vivő. A jelenlegi kormányfö (a minisztertanács elnöke) a horvát nemzetiségü Vjekoslav Bevanda. (Bosznia-hercegovinai Minisztertanács [é. n.])

114 Mindazonáltal a kormányalakítás szinte minden választást követően nehézkes, amiből arra következtethetünk, hogy az erös és egységes boszniai állam híveinek létszáma a politikai elit köreiben nem nött annyira, mint amennyire ezt a nemzetközi közösség (és minden bizonnyal a boszniai állampolgárok egy része) elvárná és szeretné.

${ }^{115}$ A minisztertanács elnökét a boszniai államelnökség jelöli ki, egyetértésben a boszniai parlamenttel. (Šelo Šabić [2005] p. 200.)
} 
Az eddig tárgyalt központi állami intézmények közül a parlament, az elnökség és a minisztertanács a demokratikus szabályoknak megfelelően kinyilvánított állampolgári akarat nyomán jön létre, különösebb szerep a daytoni megállapodás rendelkezései alapján a nemzetközi szereplőknek itt nem jut. Az alkotmánybíróság esetében a kilenc tag közül négyet a Föderáció, kettőt a Republika Srpska delegál, három bírát pedig az Emberi Jogok Európai Bíróságának (az Európa Tanács egyik fő szervének) elnöke nevez ki a boszniai államelnökséggel történő konzultációt követően. A daytoni megállapodás öt év után a szövetségi parlamentnek lehetőséget adott arra, hogy a három nemzetközi bíró posztjára új választási szabályokat alkosson - azaz öt évben maximálták a nemzetközi közösség ilyen mérvü befolyását az alkotmánybíróság müködtetésében -, (Daytoni megállapodás [1995] 4. sz. melléklet VI/1d. cikk) napjainkig azonban megmaradt a három nemzetközi bírói pozíció. ${ }^{116}$

Nem említettük még a szövetségi intézmények közül a központi bankot (centralna banka), ahol a nemzetközi jelenlétet illetően hasonló a helyzet, mint az alkotmánybíróságnál. Itt is egy átmeneti periódust határoztak meg a daytoni megállapodásban, amelynek során a három etnikum egy-egy tagját tömörítő ${ }^{117}$ irányító hatóságot (upravno vijeće) a Nemzetközi Valutaalap által - a boszniai Elnökséggel történő konzultációt követően - kinevezett nemzetközi tisztségviselő vezeti (ún. kormányzóként - guverner), s ebben az első ciklusban bizonyos korlátozásokkal müködhet csak az intézmény. A második ciklustól kezdve - a központi bankra vonatkozó törvényi szabályozási környezet megteremtését követően - az államelnökség hat évre nevezi ki az öttagúra nőtt testület tagjait, s közülük kerül ki a kormányzó is. (Daytoni megállapodás [1995] 4. sz. melléklet VII. cikk) A központi bank esetében a nemzetközi szerepvállalás sikeresként értékelhető, ebben elsősorban az Nemzetközi Valutaalapnak volt elsőrangú szerepe, amely anyagi, szakmai, technikai és a szakemberképzésben nyújtott segítsége révén - a kompetenciák fokozatos átadásával -

\footnotetext{
${ }^{116}$ A kilencfös bírói testületnek napjainkban egy német, egy moldovai és egy macedón bíró is a tagja. (Bosznia-Hercegovina Alkotmánybírósága [é. n.])

117 Itt érdemes megjegyeznünk, hogy a daytoni megállapodás alapján az etnikai arányosság követelményének kétségkívül demokratikus érvényre juttatása azonban itt is azzal a következménnyel járt, hogy sem a Föderációban élő szerbek, sem pedig a Republika Srpskában élő horvátok és bosnyákok nem jelölhetők és választhatók fenti állami szervek tisztségeire, hiszen a Föderáció csak horvát és bosnyák, az RS pedig csak szerb tagokat delegálhatott ezekbe a pozíciókba.
} 
nagyban hozzájárult a stabil monetáris politika sikeres megvalósításához. ${ }^{118}$ (Šelo Šabić [2005] pp. 203-205.) A központi bank vezető tisztségviselői mára mindannyian boszniai szakemberek. (Bosznia-Hercegovina Központi Bankja [2012])

\subsubsection{Brčko Körzet}

Az államon belül sajátos igazgatási modell érvényesül a két államrész határán fekvő északkelet-boszniai Brčkóban, amelynek hovatartozása heves vitákat generált az entitásközi határvonal meghúzásakor. A városra igényt tartottak a bosnyákok, arra hivatkozva, hogy egyrészt történelmileg hozzájuk tartozik a terület, ahol egykor többségben voltak, másrészt pedig a brčkói folyosó biztosítja a kijutást a Föderációnak északnyugat felé (lényegében Nyugat-Európa irányába). A szerbek érvelése is megalapozottnak tünik, ők arra hivatkoznak, hogy mind etnikai arányuk, ${ }^{119}$ mind pedig a terület földrajzi fekvése indokolttá teszi ragaszkodásukat Brčkóhoz. Számukra is folyosóként funkcionál ugyanis, amennyiben a Republika Srpska két nagy területi egységét köti össze, amelyek között megszakad a földrajzi kontinuitás Brčko „elvesztése” esetén. A vita eldöntésére a daytoni megállapodás egy három tagot (egy bosnyák, egy szerb és egy, a Nemzetközi Bíróság által kijelölt nemzetközi bírót) tömörítő döntőbíróságot hozott létre (Arbitral Tribunal for Dispute over Inter-EntityBoundary in Brčko Area), ennek feladata lett volna egy éven belül döntést hozni az ügyben. (Daytoni megállapodás [1995] 2. sz. melléklet IV. cikk) A végső rendezést célzó megegyezésre azonban 1999-ig kellett várni, ${ }^{120}$ ennek alapján jött létre 2000. március 8-án hivatalosan Brčko Körzet, amely kezdetben a két entitás közös kondomíniuma volt, anélkül azonban, hogy bármelyik irányítása alá tartozott volna. Területének 52\%-a a Föderációhoz tartozott, 48\%-a pedig a RS-hoz (ez utóbbi részeként maga a város is), legfőbb irányítója pedig az ún. nemzetközi felügyelő (supervisor) volt,

\footnotetext{
118 A központi bank 1997 nyarán jött létre és kezdte meg működését, az addig az országban használt változatos fizetőeszközöket pedig 1998 júniusától fokozatosan váltotta fel az új hivatalos fizetőeszköz, a konvertibilis márka.

${ }^{119}$ Az International Crisis Group (ICG) a boszniai Központi Választási Bizottság adataiból kiindulva úgy becsüli, hogy Brčko lakosságának 44\%-a szerb, 41\%-a bosnyák, 14\%-a pedig horvát, de nehéz a valós arányokat megbecsülni, mert minden valószínüség szerint többen - sokan a Brčkóért folytatott politikai küzdelem tudatos lépéseként - állandó lakhelyükként úgy jelölik meg a várost, hogy ott valójában nem tartózkodnak életvitelszerüen. (ICG [2001] p. 2.) A témában ld. még az ICG korábbi elemzését Bosnia’s Brcko: Getting In, Getting On and Getting Out címmel.

${ }^{120}$ A döntőbíróság döntését ld. az alábbi címeken: http://www.ohr.int/ohr-offices/brcko/default.asp?content_id=5327 és http://www.ohr.int/ohr-offices/brcko/default.asp?content_id=5362 (letöltés: 2012.03.09)
} 
aki egyben a főmegbízott helyettese és - egy hallgatólagos megállapodás alapján amerikai. A Brčko Körzet tehát Bosznia-Hercegovina kizárólagos szuverenitása alatt álló egységes, multietnikus, önkormányzatisággal bíró demokratikus egység, amelynek saját kormánya, törvényhozó gyülése, saját rendőrsége és bíróságai vannak. A személyek szabad mozgása garantált (fizikai határok sincsenek), de egyik államrész katonái sem tartózkodhatnak a területén. Időközben annyi változás történt, hogy nem osztja már ketté az entitásközi határvonal a körzetet, hanem megkerüli azt. Brčkót sokáig „bezzeggyereknek” tartották, amely jól példázza, hogy a súlyos megosztottság körülményeiből is létezhet kiút: a menekültek visszatérése, a multietnikus oktatási rendszer és a saját rendőri erő a lehetséges együttélést pozitívan példázó olyan esetek voltak, amelyekkel a boszniai állam sajnos nem büszkélkedhetett. A nemzetközi felügyelet megszüntetése 2005 óta napirenden van, a körzetről alkotott kép azonban egyre kevésbé tünik követendő példának. A politikai vezetés - amely a Bosznia szerte vezető erőknek számító szerb, bosnyák és horvát pártok kezében van - lényegében leképezi a két frakcióra szakadt boszniai politikai szcénát (szerb és horvát pártok kontra a bosnyák és a haladónak tekinthető erők), viszont a brčkói körzet hatékony múködtetése konszenzusos döntéshozatalt igényel. Ezt egyre nehezebb volt megteremteni a döntéshozatali folyamatokban, s 2011 végére a körzet súlyos válságba süllyedt. Az a gazdasági-fejlettségbeli előny, amire Brčko korábbi, „virágzó” időszakában szert tett, felmorzsolódni látszik, a befektetők számára a politikailag egyre bizonytalanabb környezet és az igen súlyos korrupciós fertőzöttség ${ }^{121}$ már nem teszi vonzóvá a területet. (ICG [2011] pp. 4-8.) A nemzetközi felügyeletet így azóta sem szüntették meg (éppen 2011-ben halasztották el ismét a döntést erről), s úgy tünik, Brčko sajnos nem a pozitív példának bizonyult, amit Bosznia is követhetett volna, hanem Bosznia volt a negatív példa, amelyet Brčko végül követett, sőt talán még túl is szárnyalta azt.

\footnotetext{
121 A korrupció akkor harapózott el különösen, amikor a nemzetközi felügyeleten lazítva a gazdaságpolitikai döntéseket a helyiek kezébe adták, s nem avatkoztak be felülről az eseményekbe. Az esemény egy, a gazdasági, politikai, törvényhozói stb. szféra szinte minden szegmentumára kiterjedő korrupt rendszer kiépüléséhez vezetett, ahol a nepotizmus és a kenőpénzek gyakorlata mindennapos volt. Érthető ezután, hogy az önállóság további növelésétől miért ódzkodik a nemzetközi közösség. (ICG [2011] pp. 4-8.)
} 


\subsubsection{A Föderáció és a Republika Srpska}

Az entitásokról a daytoni megállapodás (és benne a boszniai alkotmány) kevés rendelkezést tartalmaz, megelégszik annyival, hogy az elkülönült (szövetségi vagy entitás szintü) és a közös (szövetségi és entitás szintü) hatásköröket - az entitásokra vonatkozóan nagy általánosságban - felsorolja. ${ }^{122}$ (Daytoni megállapodás [1995] 4. sz. melléklet III/1-3. cikkek)

\section{A Bosznia-hercegovinai Föderáció ${ }^{123}$ rendelkezik saját törvényhozói és végrehajtó} szervvel, a bírói ág alapvető szerveivel, ${ }^{124}$ saját elnökkel, valamint állami szimbólumokkal (zászló, címer, himnusz stb.). A két entitás közül ez a kevésbé centralizált, a bosnyákok és a horvátok együttélése miatt tovább tagolódik kantonokra (amint erről korábban már volt szó), majd önkormányzatokra. A Föderáció központja Szarajevó. A kétkamarás parlament a szövetségi parlamenthez hasonlóan a Képviselők Házából és a Népek Házából áll, amelyekben mindegyik államalkotó nemzet tagjai képviselve vannak. ${ }^{125}$ A legfőbb végrehajtó testület a 16 tagú kormány, ${ }^{126}$ amelynek esetében szigorúan rögzíti az föderációs alkotmány az etnikai paritás érvényre jutásának garanciáit. Eszerint a négy éves mandátummal bíró kormányban a 16 tárca közül a három nagy etnikum nyolc, öt, illetve három helyet kap, a legnagyobb létszámú etnikum (ez esetben a bosnyák) pedig nyolc miniszteri posztjából egyet a más nemzetiségűeknek

${ }^{122}$ A két államrész saját alkotmánnyal rendelkezik, ezek a későbbi módosításokkal egységes szerkezetbe foglalva hozzáférhetők a hivatalos nyelveken és angolul is az alábbi URL-címen: http://legislationline.org/

${ }^{123}$ A Föderáció lényegében az 1994. március 18-i washingtoni megállapodással jött létre, amelyben a boszniai muszlimok és a horvátok megállapodtak abban, hogy készek föderációba tömörülni a háború lezárását követően, az új boszniai állam létrejöttekor. Ez a - zömmel amerikai közvetítéssel és nyomásra létrejött - dokumentum a háború lezárásához vezető út egyik első, fontos állomásának tekinthető, mivel nemcsak hogy véget vetett a konfliktusban álló felek közül kettő között a fegyveres szembenállásnak, de jelentős részben alapját képezte a végleges rendezést szolgáló daytoni megállapodásnak is. (Washingtoni megállapodás [1994])

${ }^{124}$ A Föderációnak van alkotmánybírósága, legfelsőbb bírósága, és az emberi jogokért felelős ombudsmani hivatala is, mely utóbbi jelentősége az etnikumok közti békés együttélés szempontjából kiemelkedő jelentőségü, s mely természetesen összetételében is megfelel az etnikai kiegyensúlyozottság elvének. Az entitásszintü intézmények mellett természetesen a kantonális és az önkormányzati szinten müködő bíróságok is a bírói hatalmi ág szerves részei. 2002-ben a fömegbízott rendeletével jött létre a bírói ág „csúcsszerve”, a Legfelsőbb Bírói és Ügyészi Tanács (Visoko Sudsko i tužilačko vijeće - VSTV, High Judicial and Prosecutoral Council). Részletesebben ld.: VSTV honlapja, http://www.hjpc.ba/

${ }_{125}$ Az etnikai paritás maradéktalan érvényesítésére a Népek Házában van mód, ahol az 58 képviselőből 17-17-17 hely jut a bosnyákoknak, a boszniai szerbeknek és a boszniai horvátoknak, a maradék hét helyen a többi nemzetiség osztozik. A 98 fös Képviselők Házában a választások eredményei alapján kerülnek elosztásra a képviselői helyek, a bejutási küszöb 5\%. (Bosznia-hercegovinai Föderáció alkotmánya [1994] IV/A/1-2. cikkek)

${ }^{126}$ A Föderáció kormányának összetételéről lásd annak hivatalos honlapját a http://www.fbihvlada.gov.ba URL-címen. 
kell, hogy átadjon; ráadásul a miniszterelnök két helyettesének a másik két államalkotó nemzet tagjai közül kell kikerülniük. Ugyanezek okok mentén az entitás elnöke két helyettesének is a másik két etnikum soraiból kell származnia. (Bosznia-hercegovinai Föderáció alkotmánya [1994] IV/B/1-2. cikkek) Az alaptörvény részletesen szabályozza, hogy melyek az entitásszintü, ${ }^{127}$ és kantonszintü, valamint a közös felelősségi körbe tartozó jogosítványok, s külön felsorolja az önkormányzatokhoz delegált jogköröket is.

A Republika Srpska ${ }^{128}$ a Föderációhoz képest erősen centralizált, itt nincsenek kantonok, az igencsak domináns szerb népelem túlsúlya mellett nem is lenne sok értelme ezek kialakításának. ${ }^{129}$ A Banja Luka-i központú RS-nek saját szimbólumai vannak (zászló, címer, himnusz stb.). Az erős elnöki rendszer és az egykamarás parlament is az erősen centralizált jelleg érvényesülését biztosította egészen 2002-ig, amikor is az államalkotó nemzetek ügyében hozott döntések miatt létre kellett hozni a második kamarát is. Így a parlament áll a korábban is létező - és jelenleg 83, négy évre választott képviselöt tömörítő - Nemzetgyülésböl (Народна Скупштина Републике Српске / Narodna Skupština Republike Srpske) és a 28 tagú Népek Tanácsából (Bujeћа народа Републике Cpncke / Vijeća naroda Republike Srpske). Előbbiben legalább négy helyet kapnak a nem államalkotó közösségek tagjai (a többi mandátum a választások eredményeként oszlik el), utóbbiban pedig egyenként nyolc képviselői helyet kapnak a szerbek, a bosnyákok és a horvátok, s négy mandátumot juttatnak az egyéb etnikai és vallási közösségeknek. (Republika Srpska Nemzetgyülés, Népek Tanácsa [é. n.]) Az államelnököt közvetlenül, négy évre választják a választásra jogosult polgárok, 2002 óta helyetteseinek száma egyről kettőre emelkedett, így mindhárom államalkotó státuszú közösség tagjai képviseltetve vannak. Az etnikai balansz elve érvényesül a négy éves

${ }^{127}$ A Föderáció kizárólagos jogkörébe tartoznak az alábbi területek: a szövetségi szabályozásnak nem ellentmondó katonai és védelmi célú intézkedések; föderációs állampolgárság; a gazdaságpolitika alakítása; pénzügyek és fiskális politika; terrorizmus és szervezett bünözés elleni küzdelem; frekvenciaelosztás a médiaszektorban; energiapolitika stb. A Föderáció és a kantonok együttesen felelnek az emberi jogok érvényre jutásáért, az egészségügyi, környezetvédelmi, infrastrukturális, valamint a szociális és jóléti intézkedésekért, és közösen szabályozzák a turizmussal és a nemzeti erőforrásokkal kapcsolatos tevékenységüket. (Bosznia-hercegovinai Föderáció alkotmánya [1994] III/1-2. cikkek)

${ }^{128}$ A RS előképének tekinthető Boszniai Szerb Köztársaság szakadár formációként jött létre 1992 januárjában, a nemzetközi közösség azonban illegitim entitásnak tekintette végig a háború alatt. Éppen ez az oka annak is, hogy a szakirodalom szívesebben használja a szerb többségü államrészre a Republika Srpska megnevezést, ezzel kívánják ugyanis megkülönböztetni a daytoni rendezés során a nemzetközi közösség által legitimnek elismert államrészt a háború alatti szakadár területtöl.

${ }^{129}$ A Republika Srpskában az entitásszint alatt ugyan léteznek régiók (az öt régió: Banja Luka, Doboj, Bijeljina, Kelet-Szarajevó és Trebinje), de ezek nem tekinthetőek a kantonokhoz hasonló önálló államigazgatási szintnek. 
mandátummal bíró kormány összetételében is, ahol a tárcák elosztása ${ }^{130}$ a Föderációnál már ismertetett módon történik. A legfőbb tanácsadó testület a Szenátus, amelynek 55 tagját ${ }^{131}$ az államelnök a tudományos és kulturális élet, valamint a közszféra leginkább elismert tagjai közül nevezi ki, s amelynek feladata a tanácsadás a legnagyobb horderejü politikai, nemzeti, gazdasági és kulturális kérdésekben. Üléseit az államelnök vezeti. (Republika Srpska alkotmánya [1992] 89. cikk)

\subsubsection{A boszniai állam müködési zavarai}

Az entitások államjogi szerkezetének ismertetését követően két olyan kérdéskörre érdemes kitérni, amelyek nagyban befolyásolják a két entitás és a boszniai állam müködését is, ezek: a két entitás viszonya a közös államhoz és egymáshoz, valamint az államalkotó nemzetekről szóló vita.

A Föderáció létrejötte Bosznia-Hercegovinán belül még az 1991-1995-ös délszláv válság végén elért megbékélésen és konszenzuson alapult a boszniai muszlim és horvát közösségek között, s fontos alapját képezte a végső, daytoni rendezésnek is. Mindez azonban nem jelenti azt, hogy az együttélés azóta is harmonikus lenne a két nemzet között. S bár a szakirodalomban kevesebb szó esik a Föderáción belüli bosnyákboszniai horvát vitákról, mint a Föderáció és a RS közti ellentétekről, előbbi korántsem elhanyagolható, s szintén hozzájárul az állam elégtelen működéséhez.

A nézeteltérések egyik gyökere egészen a jugoszláv dezintegrációs folyamat kezdetéig visszavezethető, amikor is 1990-1991-ben a függetlenedési szándékok erősödésével napirendre került Bosznia további sorsa is. A három etnikum elképzelése a független Boszniáról nagyban különbözött abban, hogy unitárius vagy föderális struktúrát vizionáltak-e. A bosnyákok a legnagyobb etnikumként (az 1991-es népszámlálás szerint arányuk akkor 43,47\% volt) egységállamot szerettek volna, s ellenezték az ország területének kisebb egységekre tagolását. Ez utóbbihoz a boszniai szerb és horvát

\footnotetext{
${ }^{130}$ A RS kormányának összetételéről lásd annak hivatalos honlapját a http://www.vladars.net URL-címen. ${ }^{131}$ A Szenátus tagjait lásd az alábbi címen: http://www.predsjednikrs.net/index.php?option=com_content\&view=article\&id=121\&Itemid=169\&lang $=\mathrm{rs}$
} 
közösség ragaszkodott (arányuk 1991-ben 31,21\%. illetve 17,38\% volt), ${ }^{132}$ s végül el is érték céljukat. (Nacionalni sastav stanovništva [1993] p. 7.) A szerbek és horvátok úgy vélték, hogy „kisebbségként” a föderatív tagoltság - és ennek következtében a gyenge szövetségi állami kompetenciák és a nagyfokú decentralizáció - garantálja számukra, hogy a legnagyobb etnikummal szemben (és amellett) egyenrangú államalkotó nemzetként vehessenek részt a politikai döntéshozatali és érdekartikulációs folyamatokban. A nemzetközi közösség érthető módon támogatta ezt az igényt, a daytoni struktúra, s az etnikai paritáshoz való mindenekfeletti ragaszkodás is jól bizonyítja ezt. A RS politikusainak - és nyilván többségi szerb lakosainak - körében nagyobb az ellenszenv a közös állam iránt, de a Föderációban is szakadással fenyegetnek a belső viták, méghozzá a Föderáció szakadásával. A daytoni rendezésnél a második igazgatási szint, vagyis a Föderáció kantonokra tagolása éppen azt célozta, hogy ily módon a jogkörök azon nemzethez kerüljenek, amely az adott kantonban többségben él. A legkisebb létszámú horvátoknak kedvezett tehát a döntés, ők azonban ennél ma már többet szeretnének. A boszniai horvátság egy jelentős része ugyanis egyre elégedetlenebb a „társutas” pozícióval, s véleményük szerint a bosnyákok elnyomják őket a föderációs államrészben, éppen ezért a szerbekhez hasonló pozíciót szeretnének. Ha ez megvalósulna - amire jelenleg vajmi kevés esély mutatkozik -, akkor az ország nem két, hanem három államrészből állna, s mindegyik államalkotó nemzet saját területén kizárólagos jogköröket nyerve maga irányítaná sorsát. ${ }^{133}$

Ehelyütt foglalkozunk egy másik vitás kérdéskörrel is, az államalkotó nemzetek ügyével. A boszniai hatályos alkotmány - a daytoni megállapodás 4. számú melléklete - rögzíti, hogy Bosznia-Hercegovina államalkotó nemzetei közé a bosnyákok, a szerbek és a horvátok tartoznak. ${ }^{134}$ A két államrész, a Föderáció és a Republika Srpska

\footnotetext{
${ }^{132}$ Az etnikai arányokat tekintve megbízható friss adat sajnos nem áll rendelkezésünkre, csupán becslések, mert Bosznia - hasonlóan a balkáni országok nagy részéhez - 1991 óta nem tartott népszámlálást. A halogatásnak komoly oka van: amíg a számok nem tükrözik tényszerúen a valós állapotokat, addig a politikai szcéna szereplöi tét nélkül hivatkozhatnak saját „,felméréseikre”, s a megfelelően torzított adatokkal támaszthatják alá aktuális mondanivalójukat. A politikai játszmákon túl tehát statisztikai, nemzetgazdasági stb. okokból is hasznos lenne megismerni a lakosság pontos lélekszámát és összetételét, s egy megbízható felmérés minden kétséget kizáróan megmutatná a kilencvenes évek háborúinak hatásait is az etnikai átrendeződés vonatkozásában. BoszniaHercegovinában egyébként 2013-ban tartják majd a békekötés óta az első népszámlálást.

${ }^{133}$ A kivitelezés persze akkor sem lenne egyszerü, ha elvi síkon lehetséges volna egy ilyen megoldás: a vegyes etnikumú részek hovatartozásának kérdése újabb vitákat generálna.

${ }^{134}$ Az alaptörvény e tekintetben tehát nem kíván szakítania a korábbi jugoszláv hagyományokkal, amikor is a titói föderáció létezésének mintegy fél évszázada alatt fokozatosan formálódott a ,jugoszláv nemzetek”, a ,jugoszláv nemzetiségek” és az „egyéb nemzetiségek” kategóriájába sorolt etnikai és vallási
} 
alkotmányainak egyes rendelkezései az államalkotó státuszról kezdetben ellentmondtak a velük szemben nyilvánvalóan magasabb rendü boszniai alkotmánynak. Az alkotmányos jogsértés tényére Alija Izetbegović akkori államelnök hívta fel 1998-ban a figyelmet és fordult a boszniai alkotmánybírósághoz (AB), azt állítva, hogy alkotmánysértőek és diszkriminatívak az entitások alkotmányai, többek között az államalkotó nemzetek ügyében. A Föderáció alaptörvényében tudniillik a bosnyákokat és a horvátokat jelölték meg államalkotó nemzetnek, a RS-ban pedig ugyan nem nevesítették a szerbeket alkotmányos nemzetként, de egyfelől az a tény, hogy említést sem tettek más nemzeti közösségekröl, másfelöl és az egész alkotmány szellemisége arra engedett következtetni, hogy nem is kívánták a más nemzetiségü RS-ben élő állampolgárokat egyenrangúként kezelni a szerbekkel. Ez a helyzet a gyakorlatban azt eredményezte, hogy a Föderációban az ott élö szerbek politika jogaikat csak korlátozottan gyakorolhatták (a passzív választójoguk pl. ugyan megvolt, de aktív már nem), mint ahogyan a RS-ban élő bosnyákok és horvátok sem válhattak ugyanezért az ottani politikai közösség teljes jogú tagjává. Ez a szabályozás pedig nyilvánvalóan nem csak a nyugati demokráciákban megszokott normáknak, de a nemzetközi közösség abbéli szándékának is ellentmondott, hogy a három etnikum közti egyenlőséget mindenek felett garantálják Bosznia területén. Annál is inkább, mert hangsúlyosan támogatott elv volt a rendezés során a menekültek visszatérésének támogatása - $\mathrm{s}$ ennek részeként az ún. kisebbségi menekülteké is, vagyis pl. a bosnyákok visszatérése a RS-ba -, s az állam multietnikus jellegének megőrzése, ${ }^{135}$ így meglehetősen álságos lett volna a

közösségeknek a sora. Az az etnikum, amelynek a jugoszláv föderációban volt ,,anyaállama” (ahol értelemszerüen többséget alkotott), jugoszláv nemzet volt (pl. szerbek, horvátok, szlovének, macedónok, montenegróiak), azokat a népeket pedig, amelyek jelentős számban ugyan, de több ország területén éltek (de Jugoszláviában nem volt anyaállamuk), a jugoszláv nemzetiség megnevezéssel illették (pl. albánok). A második Jugoszláviában a ,jugoszláv nemzet” kategória feleltethető meg a ma használatos „államalkotó nemzet” kitételnek. A jelenleg hatályos boszniai alkotmány a három államalkotó nemzet felsorolása után említést tesz még a „egyéb” (others) kategóriáról (a szakirodalomban néhány helyen „,mások”-nak fordítják), a meglehetősen szerencsétlen módon megválasztott kifejezés az egyéb etnikai és vallási közösségekhez tartozókra utal. A boszniai parlament 2003-ban fogadta el a nemzeti kisebbségek védelméről szóló törvényt, amelyben 17 kisebbséget nevesítenek, ezek: albán, cseh, lengyel, macedón, magyar, montenegrói, német, olasz, orosz, roma, román, ruszin, szlovák, szlovén, török, ukrán, zsidó. (Zakon o zaštiti prava pripadnika nacionalnih manjina. [2003] 3. cikk)

${ }^{135}$ A boszniai alkotmánybíróság $(\mathrm{AB})$ az alkotmányellenességet megállapító döntésében hivatkozott többek között a háború utáni etnikai arányokra, amelyekből kitűnik, hogy mindkét államrész etnikai arányai jelentősen módosultak ugyan a többség javára, de még mindig nem elhanyagolható a kisebbségként az egyik vagy a másik entitásban élők számaránya. Az AB azt is megállapította, hogy az entitások alkotmányaiból fakadó diszkriminatív gyakorlat visszarettenti a kisebbségi menekülteket az eredeti lakhelyükre történő visszaéréstől. (ICG [2002] p. 4.) A hivatkozott etnikai arányváltozások a következők (1991 és 1997 között): a Föderációban a bosnyákok aránya 52,09\%-ról 72,61\%-ra nőtt, míg a szerbek aránya ugyanitt 17,62\%-ról 2,32\%-ra csökkent (a horvátok aránya érdemben nem változott); a Republika Srpska területén a szerbek aránya 54,3\%-ról 96,79\%-ra nőtt. (AB határozat U-5/98-III. [2000]) 
nemzetközi szereplők részéről a diszkriminatív, s a szeparációt tovább erősítő gyakorlat támogatása, ráadásul felvetette volna az etnikai tisztogatás támogatásának nyugtalanító gondolatát is.

Az alkotmánybíróság döntésében (AB határozat [2000]) elismerte az alkotmányellenesség tényét, majd ezután széleskörü és heves vita vette kezdetét a témáról, amelyben részt vettek a helyi politikai döntéshozók, a nemzetközi alkotmányjogi szakértők, s társadalmi vitára is sor került. A mintegy másfél éves kisebb alkotmányos válságként is jellemezhető - időszak alatt az entitások parlamentjei képtelenek voltak határozni alkotmányaik szükséges módosításáról, ezért 2002-ben végül az OHR „hatalmi szóval” zárta le a kérdést, és rendelkezett az alaptörvények, valamint a választási törvény szükséges változtatásairól. (OHR döntés [2002/a,b,c]) Ekkor lett hivatalos nyelv a RS-ban a szerb mellett a bosnyák és a horvát is, hivatalos írásmód pedig a cirill mellett a latin betüs is. A döntést pozitívként értékelhetjük abból a szempontból, hogy egyértelmű elmozdulást jelez a helyes irányba, vagyis egy olyan Bosznia víziója felé, ahol az etnikai arányosságnak mindent alárendelő államjogi rendszerben teret nyer egy, a multietnicitást és az emberi jogok érvényesülését előmozdító szabályozási elem.

Az imént ismertetett ügyre és annak következményeire azonban csak a helyes irányban tett egy lépésként (vagy inkább elmozdulásként) tekinthetünk, hiszen az alkotmánysértést ugyan megszüntették a bosnyákok, a szerbek és a bosnyákok vonatkozásában, de továbbra is fennmaradt az „egyéb” kisebbségek, vagyis más nemzeti és vallási közösségek esetében. ${ }^{136}$ Ezt erősítette meg az Emberi Jogok Európai Bíróságának (EJEB) 2009-es döntése is, amely kimondta, hogy a boszniai alkotmány diszkriminatív rendelkezéseket tartalmaz, amennyiben bizonyos politikai pozíciók betöltését csupán az államalkotó etnikumok (bosnyákok, szerbek, horvátok) számára

\footnotetext{
${ }^{136}$ A 2002-es alkotmánymódosítások alapvetően a három államalkotó nemzet alkotmányos jogainak helyreállitására fókuszáltak, de néhány helyen érintették a többi nemzeti közösség (az „egyéb” népcsoportok) tagjainak jogait is. Így például rendelkeztek a két entitás kormányainak összetételéről, miszerint a Föderációban a 16 tagú kormányban 8,5 és 3 helyet kell juttatni a bosnyákoknak, a horvátoknak és a szerbeknek, de a legnagyobb csoportnak (a bosnyákoknak) egy miniszteri tárcát át kell adniuk a nem államalkotó etnikumok valamely, a miniszterelnök által kijelölt képviselöjének. A Republika Srpskában szintén a 8-5-3-as szabályt kell alkalmazni a kormányalakításnál, csak itt sorrendben a szerbek, a bosnyákok és a horvátok kapják ezeket a helyeket, de itt is a Föderációnál leírt módon kell biztosítani a kormányban egy helyet a nem államalkotó kisebbségeknek. Az OHR továbbá rendelkezett arról is, hogy a legjelentősebb politikai-közjogi posztokon és a közszférában is érvényesíteni kell az egyenlő reprezentáció elvét az etnikai arányoknak megfelelően. (Šelo Šabić [2005] p. 202.)
} 
teszi lehetővé. (Sejdić és Finci ügy [2009]) A keresetet egy boszniai roma és egy zsidó állampolgár indította, ${ }^{137} \mathrm{~s}$ az EJEB a Boszniát elmarasztaló döntése indoklásában több nemzetközi emberi jogi egyezmény megsértésére is hivatkozott. ${ }^{138}$ (Semanić [2011] p. 57.) Az EJEB döntése ugyan nem hozhat gyors áttörést a kérdésben, hiszen ahhoz a boszniai alkotmányt kellene módosítani, de mindenképpen fontos mérföldkőnek tekinthető az alkotmányozási válságban és újfent aláhúzza a változtatás szükségességét.

A boszniai állam felépítésének, alapvető szabályozó elveinek, valamint a müködést gátló tényezőknek az ismertetésével felvázoltuk azt a környezetet, amely a nemzetközi területi adminisztráció müködésének közegét jelenti. A következő alfejezetben bemutatjuk a nemzetközi területi igazgatás civil aspektusainak egyik alapvető intézményét, a fömegbízott hivatalát, ezt követően pedig a két választott dimenzió (biztonság, demokratikus intézményépítés) mentén bemutatjuk és értékeljük a nemzetközi területi igazgatás boszniai modelljét. Az egyes dimenzióknál sorra vesszük azokat a nemzetközi szervezeteket is, amelyek a legfontosabb szerepet játszották az adott politikaterület müködtetésében.

\subsubsection{A fömegbízott intézménye}

A 10. számú melléklet a nemzetközi szerepvállalás szempontjából az egyik legfontosabb része a daytoni megállapodásnak. Ez rendelkezik ugyanis a fömegbízott kinevezéséről, aki a békemegállapodás polgári rendelkezéseinek végrehajtásáért a legfelsőbb szinten felelős. A melléklet I. cikk 1. pontjában közli, hogy a civil aspektusok mit is jelentenek: a humanitárius segélytevékenység folytatását, ameddig az

\footnotetext{
137 A keresetet 2006-ban Dervo Sejdić és Jakob Finci indította, előbbi roma, utóbbi zsidó származású boszniai állampolgár (mindketten neves közéleti személyiségek), akik azt sérelmezték, hogy romaként és zsidóként (tehát ha nem kívánják magukat azonosítani a három államalkotó nemzet egyikével sem) sem a Népek Házábába (a boszniai parlament felsőházába) nem indulhattak a képviselői helyek egyikéért, sem pedig a boszniai államelnöki pozícióra nem pályázhattak, mert ezen posztok megszerzésére csak az államalkotó nemzetek tagjainak volt a hatályos jogszabályok alapján lehetősége. Az EJEB az ügy vizsgálata során érvelésében utalt arra, hogy Bosznia-Hercegovina az Európa Tanácshoz történő 2002-es csatlakozásakor vállalta, hogy felülvizsgálja választási törvényeit, majd az Európai Unióval 2008-ban kötött stabilizációs és társulási egyezményében újfent megerösítette ezen vállalását - az ügy tárgyalásáig azonban nem teljesítette ezen ígéretét. (Halmai et al. [2012] p. 435.)

${ }^{138}$ Az EJEB döntése szerint: a Népek Háza képviselöi választása esetében sérült az Emberi jogok és alapvető szabadságok védelméről szóló európai egyezmény (EJEE) 14. cikke (diszkrimináció tilalma) az 1. számú kiegészítő jegyzőkönyv 3. cikkével (szabad választáshoz való jog) összhangban. Az államelnöki poszt ügyében a Bíróság megállapította, hogy az EJEE 12. számú kiegészítő jegyzőkönyvének 1. cikke a megkülönböztetés általános tilalmáról - sérült. (Polgári [2010] pp. 82-83.)
} 
szükséges; az infrastruktúra helyreállítását és a gazdasági újjáépítést; a boszniai politikai és alkotmányos intézmények létrehozását; az emberi jogok tiszteletben tartásának előmozdítását; a menekültek visszatérését és a szabad és egyenlő választások megtartását. Ezen célok megvalósításában számos kormányközi és nem-kormányzati nemzetközi szervezet és ügynökség részt vesz, köztük a koordináció pedig a főmegbízott feladata. (Daytoni megállapodás [1995] 10. sz. melléklet I. cikk) Feladata még a polgári rendelkezések megvalósulásának folyamatos ellenőrzése, kapcsolattartás a nemzetközi közösség térségben aktív tagjaival és a helyi lakosság képviselöivel, bármilyen felmerülő nehézség esetén a megoldás előmozdítása; a donorkonferenciákon való részvétel, időközönként jelentések készítése arról, hogy a polgári rendelkezések megvalósulása miként halad, valamint a Nemzetközi Rendőri Erők (International Police Task Force - IPTF) irányítása. (Blockmans [2007] pp. 65-66.)

A daytoni megállapodás rendelkezik arról is, hogy a koordináció fő szerve a nemzetközi jelenlét polgári aspektusait illetően a főmegbízott elnökletével müködő ún. Közös Polgári Bizottság (Joint Civilian Commission) lesz. A fömegbízott hatásköre csak a nemzetközi közösség polgári tevékenységének irányítására terjed ki, a katonai ügyekben semmiféle jogosítvány nem illeti meg. A nemzetközi biztonsági jelenlét legfőbb koordináló szerve és felelőse ugyanis az IFOR (Implementation Force). A főmegbízott legfeljebb információt cserélhet az IFOR parancsnokságával, s részt vehet a - polgári jelenlét esetében létrehozott Közös Polgári Bizottság mintájára létrehozott - Közös Katonai Bizottság (Joint Military Commission) ülésein. ${ }^{139}$

A daytoni megállapodás eredetileg egy évre irányozta elő a nemzetközi katonai jelenlétet a háborúból éppen csak kilábaló országban, a civil igazgatásban való nemzetközi részvételt pedig - amint az fentiekben kiderült - öt-hat évre. Azonban hamarosan nyilvánvalóvá vált, hogy a nemzetközi jelenlétre hosszabb ideig lesz szükség Boszniában, $\mathrm{s}$ nemcsak azért, mert a daytoni megállapodásban kitüzött célok megvalósítása lassan haladt, hanem elsősorban azért, mert az első demokratikus választások 1996 szeptemberében a nacionalista erők elsöprő győzelmét hozták. Mindhárom etnikum esetében a legtöbb szavazatot azok a nacionalista pártok kapták, amelyek a háború alatt is a legfőbb politikai erőnek számítottak, nevezetesen a

\footnotetext{
${ }^{139}$ Itt kell megjegyeznünk, hogy a nemzetközi polgári és katonai jelenlét ilyen éles szétválasztása számos problémát okozott a későbbiekben.
} 
bosnyákoknál a Demokratikus Akciópárt (Stranka Demokratske Akcije - SDA), a boszniai horvátoknál a boszniai Horvát Demokratikus Közösség (Hrvatska demokratska zajednica Bosne i Hercegovine- HDZ BiH), a boszniai szerbeknél pedig a boszniai Szerb Demokrata Párt (Српска демократска Странка / Srpska Demokratska Stranka - SDS ). ${ }^{140}$ Az etnikai megosztottság tehát továbbra is igen erős volt az országban, s a nemzetközi döntéshozók attól tartottak, hogy a nemzetközi erök kivonulását az ellentétek kiéleződése, akár újabb háborús konfliktussá eszkalálódása követheti.

Emiatt úgy döntöttek, hogy meghosszabbítják mind a polgári, mind pedig a biztonsági nemzetközi jelenlétet, elöször 1998 júniusáig, majd egy újabb döntéssel meg nem jelölt időpontig (egy felülvizsgálati mechanizmus müködtetése mellett). (Zaum [2007] p. 83.) Az ezt követő időszakra egyfajta kettősség jellemző: egyfelől megkezdődött a kompetenciák helyi szerveknek történő átadása, másfelől a nemzetközi közösség nemcsak, hogy kinyilvántotta a továbbiakban is elköteleződését - immáron meg nem határozott időtartamra - a boszniai állam stabilizálása és demokratizálása mellett, de még meg is erősítette azt a fömegbízott hatáskörének kiszélesítésével. Ez utóbbiról a döntés a Békevégrehajtó Tanács Bonnban, 1997 decemberében tartott ülésén született meg, emiatt nevezik a széleskörü kompetenciákat bonni jogosítványoknak (bonn powers) is. Ezzel a döntéssel a fömegbízott hatáskörét a nemzetközi civil adminisztrációkra addig nem jellemző módon kiterjesztették, s olyan erős ellenőrző és végrehajtó jogosítványokat telepítettek a posztra, hogy a fömegbízott ezután több területen de facto korlátozhatatlan teljhatalommal bíró személy lett. A daytoni megállapodás röviden definiálja csak a fömegbízott hatásköreit, azt azonban leszögezi, hogy a békemegállapodás polgári rendelkezéseinek végrehajtásáért legföbb szinten a főmegbízott felelős, s az ő joga minden ide tartozó ügyben a végső döntést meghozni. (Daytoni megállapodás [1995] 10. számú melléklet, 5. cikk) A meglehetősen általános és szükszavú daytoni megállapodáshoz képest a bonni jogosítványok a következő jogokat foglalják magukba: a fömegbízottnak joga van felülvizsgálni és módosítani minden, a boszniai jogalkotási folyamatban született jogszabályt; joga van kikényszeríteni a jog érvényesítését; jogosult elbocsátani hivatalából olyan

\footnotetext{
${ }^{140}$ A két utóbbi párt esetében azért tanácsos a „boszniai” jelző használata, mert mind a HDZ-nek, mind pedig az SDS-nek létezik az anyaországi, vagyis horvátországi és szerbiai megfelelője. A dolgozat további részében a HDZ és az SDS a boszniai pártokra utal majd.
} 
tisztségviselőket, akik véleménye szerint gátolják a daytoni megállapodásban foglalt rendelkezések végrehajtását.

A fömegbízott hatáskörének ilyen módon történő kiszélesítése sajátos helyzetet eredményezett: ahelyett, hogy az OHR fokozatosan átadta volna jogosítványait a helyi intézményeknek és így hozzájárult volna az állam intézményi kapacitásának erösítéséhez, éppen ennek ellenkezője történt: újabb jogköröket vont magához, tovább gyengítve a helyi szintet. Ez az irányváltás a nemzetközi igazgatási modellek természetes fejlődési logikájának nyilvánvalóan ellentmond, s indoklásként azt szokták felhozni, hogy azért volt erre szükség, mert csak ily módon voltak rákényszeríthető a boszniai politikai szereplők a helyes irányba történő haladás, és az ehhez szükséges reformok elfogadása. Ahogyan Julian Braithwaite, korábbi főmegbízott-helyettes találóan megfogalmazta: „A boszniai intézmények nagyon gyengék voltak, ez része volt a problémának. De annak érdekében, hogy a nacionalista erőket meggyengítsük, gyengévé kellett tennünk azokat az intézményeket, amelyeket irányításuk alatt tartottak." (Søberg [2008] p. 717.)

A bonni jogosítványaikkal egyébként a különböző főmegbízottak eltérő mértékben éltek. Westendorp, Petrisch és Ashdown mindhárman gyakran alkalmazták, SchwartzSchilling kevésbé (ő a direkt beavatkozás helyett inkább egyfajta felügyelő szerepként értelmezte a fómegbízotti pozíciót), utódja, Lajčák azonban visszatért a keménykezü stílushoz. ${ }^{141}$ A jelenlegi főmegbízott, Inzko újra inkább a helyi erőkkel való kompromisszumkeresést preferálja. A leginkább karaketeres főmegbízott (és minden bizonnyal személyiség is) Paddy Ashdown volt, aki egyetlenként töltötte ki teljes hivatali idejét, s a legtöbbször élt a bonni jogosítványokkal: 2002 és 2006 között több mint 400 alkalommal. (Domm [2007] p. 165.)

Az OHR megítélése meglehetősen ambivalens, egyfelől igaz hogy hivatali idejük alatt az említett nemzetközi képviselök - többször a „bonni fegyverrel revolverezve” a helyieket - számos eredményt elértek: Westendorp ideje alatt végre egységesítették a két államrészben addig különböző rendszámtáblákat és telekommunikációs

\footnotetext{
${ }^{141}$ A boszniai fömegbízottak (hivatali idejük zárójelben): Carl Bildt (1995-1997), Carlos Westendorp (1997-1999), Wolfgang Petrisch (1999-2002), Paddy Ashdown (2002-2006), Christian SchwarzSchilling (2006-2007), Miroslav Lajčák (2007-2009), Valentin Inzko (2009-).
} 
jogszabályokat, s olyan nemzeti szimbólumok is elfogadásra kerültek, mint a zászló, a címer és a nemzeti valuta (konvertibilis márka). Petrisch eredményei közül a legjelentősebbek az egységes tulajdonjogi szabályozási környezet megteremtése volt a két entitásban, valamint hivatali ideje alatt a nagyszámú menekült visszatérése. Ashdown teljesítményének értékelésénél ehelyütt csak arra utalunk, hogy ő kiemelten kezelte a gazdaságfejlesztés kérdését, s tevékenysége során többször hangsúlyozta, hogy Boszniának olyan fejlesztési irányokat kell megjelölnie és követnie, amellyel felgyorsíthatja az európai integrációhoz való közeledést, s ennek érdekében kemény kézzel kell felszámolni a fejlődést gátló tényezőket (programjára egyébként gyakran utalnak találóan a „bulldózer kezdeményezés” kifejezéssel). (Ó Tuathail [2006] p. 147.)

Másfelől viszont sok kritika is éri a fömegbízotti intézményt, elsősorban azzal összefüggésben, hogy gátolja az önnfennartó államhoz szükséges intézményi és politikai környezet fejlődését. Utóbbi esetében az OHR tevékenységével lényegében teret nyit a felelőtlen politizálás gyakorlatának Boszniában, hiszen a bonni korrekciósintervenciós mechanizmusokkal a kívánatos irányba tereli ugyan az eseményeket, anélkül azonban, hogy a nemkívánatos irányba igyekvőknek ténylegesen szembe keelene nézniük tetteik következményeivel. A fömegbízotti intézmény megszüntetése lényegében 2006 óta napirenden van, de mivel az etnikai-nacionalista alapvetések mentén szétszabdalt boszniai politikai szcénában mára sem jellemző az állam hatékony müködtetéséhez - és hoszzú távú fenntartásához - szükséges kompromisszumos hajlandóság, ezért az OHR továbbra is a helyén marad.

\subsection{Biztonság}

\subsubsection{Nemzetközi katonai erök}

A háború lezárása után a békés viszonyok megteremtése és a fegyveres harcok kiújulásának megakadályozása volt a nemzetközi szereplők elsődleges prioritása, éppen ezért 1995 és 1997 között a nemzetközi igazgatás biztonsági aspektusa hangsúlyosabb volt, mint a civil. A daytoni megállapodás is meglehetős részletességgel szabályozza a 
nemzetközi katonai és biztonsági jelenlétet, melynek a háború alatt is voltak előzményei.

Az ENSZ békefenntartók (ENSZ Védelmi Erő, United Nations Protection Force UNPROFOR) a térségben 1992 óta állomásoztak, ${ }^{142}$ először Horvátország területén, majd miután a háború áthúzódott Bosznia területére, még ugyanezen év nyarán a mandátumot ide is kiterjesztették. ${ }^{143} \mathrm{Az}$ UNPROFOR horvátországi - és egyáltalán balkáni - jelenlétét eredetileg egy évre tervezték, de kiderült, hogy ez a délszláv válság súlyosságának durva alulbecslését jelentette. A mandátumot az egy év letelte után folyamatosan hosszabbították, s újabb és újabb tevékenységekre terjesztették ki. (Wentz [1997] p. 15.)

Az ENSZ-erők egyik elsődleges feladata mind Horvátországban, mind pedig Boszniában a civil lakosság védelme volt, ennek biztosítására hozták létre az ún. védett övezeteket (zónákat) (United Nations Protected Area - UNPA), ahol demilitarizált környezetben kellett a lakosságot megóvni a fegyveres harcok súlyos következményeitől. A három UNPA-zóna Horvátországban Krajina, valamint Kelet- és Nyugat-Szlavónia voltak, ezeken a területeken élt a horvátországi szerb lakosság túlnyomó része. Ezen túl Horvátországban a délszláv válság lezárását célzó béketárgyalások biztonságos környezetének megteremtése, bizonyos határőrizeti és vámrendészeti funkciók ellátása, valamint helyenként a leszerelési és tűzszüneti megállapodások ellenőrzése is a mandátum része volt. Boszniában ez a szerep továbbiakkal egészült ki: itt hangsúlyos feladatként jelent meg a humanitárius segélyszállítmányok célba juttatásának elősegítése, valamint az ENSZ Menekültügyi Főbiztossága (United Nations High Commission for Refugees - UNHCR) és a Vöröskereszt térségbeli munkájának segítése. Speciális szerepe volt az UNPROFOR-

\footnotetext{
${ }^{142}$ Horvátországban 1990 óta a szerbek által többségben lakott részeken (Krajina, Kelet- és NyugatSzlavónia, Baranya) feszültség bontakozott ki a szerbek és a horvátok között, amely 1991-re fegyveres konfliktussá eszkalálódott, s amelyben a horvátokkal szemben a szerbek oldalán hamarosan a Jugoszláv Néphadsereg (Jugoslovenska Narodna Armija - JNA) alakulatai is támogató erőként jelentek meg. Horvátország úgy döntött, hogy a nemzetközi közösség segítségét kéri olyan államként, amelynek szuverenitását és területi integritását külső (szerbiai) támogatással saját kisebbsége (a horvátországi szerbek) veszélyezteti. Az UNPROFOR felállításáról 1992. február 21-én, 743. számú BT határozata elfogadásával döntött az ENSZ Biztonsági Tanácsa. (UN Peacekeeping Operations - UNPROFOR [é. n.]) ${ }^{143}$ Témánk szempontjából kevésbé jelentős, de érdemes megemlíteni, hogy az első délszláv válság idején, 1992. december 11-én, a BT 792. sz. határozatával az UNPROFOR mandátumát Macedóniára is kiterjesztette. (S/RES/792. [1992])
} 
nak a boszniai repüléstilalmi övezet ellenőrzésében is. ${ }^{144}$ Boszniában is létrehoztak az ENSZ-erők védelme alatt álló ún. biztonságos övezeteket (safe area, de nevezték biztonságos menedéknek, safe haven-nek is), ezek a következők voltak: Srebrenica, Szarajevó, Tuzla, Žepa, Goražde és Bihać. ${ }^{145}$ A legtöbb ilyen védett zónában bosnyák többségi lakosságú települések „ékelődtek be” az egyébként szerb többségü területekbe. (UN Peacekeeping Operations - UNPROFOR [é. n.])

1992 és 1995 között a békefenntartók mandátumukat tekintve inkább az első generációs békefenntartásra jellemző szerepet láttak el, amely elsősorban a felek szétválasztására és a békés viszonyok biztosítására fókuszált. A szükre szabott mandátum, az alacsony létszám és az elégtelen fegyverzet miatt azonban ez a visszafogott szerepkör nem volt alkalmas arra, hogy a békefenntartók feladatuknak megfeleljenek. ${ }^{146}$ Mandátumuk alapján csak ellenük irányuló támadás esetén, tehát önvédelmi célból használhatták csupán fegyvereiket, ennek következményeként több esetben előfordult, hogy a védelmük alá helyezett civil lakosokat mégis megtámadták, s az UNPROFOR nem tudta védelmüket biztosítani. ${ }^{147}$ A leginkább elhíresült eset az 1995 júliusában Srebrenicában lezajlott mészárlás volt, ahol néhány hét alatt mintegy 8000 bosnyák férfit és fiút végeztek ki szisztematikusan és helyeztek tömegsírokba a szerb katonai és félkatonai erők. Az események a térségben állomásozó holland kéksisakosok közvetlen szomszédságában történtek - az ENSZ-katonáknak tudomásuk volt a bosnyák lakosság összegyüjtéséről, szétválogatásáról, a nők, öregek és gyerekek elszállításáról, s végül a férfiak kivégzéséről is -, többek szerint az UNPROFOR-misszió végső összeomlása ezzel az eseménnyel teljesült be. (Oellers-Frahm [2005] p. 187.)

\footnotetext{
144 1992. október 9-én, a 781. sz. határozatában rendelkezett az ENSZ BT a boszniai repüléstilalmi övezet felállításáról. (UN Peacekeeping Operations - UNPROFOR [é. n.])

${ }^{145}$ Srebrenica biztonságos övezetté nyilvánítására az 1993. áprilisi 819. sz. BT határozattal került sor, ezt követően nyilvánítottak májusban a 824-es határozattal újabb területeket safe area-nak. (S/RES/819, $\mathrm{S} / \mathrm{RES} / 824$ [1993])

${ }^{146}$ Ezzel a ténnyel (vagyis, hogy az UNPROFOR-erők nem alkalmasak békekikényszerítési feladatok ellátására) az ENSZ is tisztában volt, ezért fókuszáltak a szerényebb eszközökkel is ellátható feladatokra, pl. a humanitárius szállítások biztosítására és a biztonságos zónák védelmére. (Mely utóbbi sajnos nem az elvárásoknak megfelelően sikerült.) (Oellers-Frahm [2005] pp. 186-187.)

147 A mandátumot - az ENSZ fótitkárának ellenzése mellett - 1993 júniusában a BT 836. sz. határozatában kiterjesztette azzal a szándékkal, hogy megakadályozzák: a szerb erők újabb támadásokat intézzenek a védett területek ellen. A kibővített mandátum lehetővé tette „minden szükséges eszköz bevetését, beleértve az erőszak alkalmazását is" a támadások megfékezésére, a békefenntartók azonban nem szívesen éltek ezzel a felhatalmazással (ld. Srebrenica). (S/RES/836 [1993])
} 
Az UNPROFOR struktúráját 1995 márciusában megváltoztatták, ${ }^{148}$ és a három országban (Horvátország, Bosznia és Macedónia) állomásozó kontingens mandátuma ettől kezdve (a háború lezárásáig) szétvált. Boszniában - változatlan név alatt - az UNPROFOR-erők 1995 decemberéig a térségben maradtak, amikor is a daytoni rendezés nyomán felállt az IFOR.

A daytoni megállapodás $1 \mathrm{~A}$ és $1 \mathrm{~B}$ számú melléklete a katonai rendelkezéseket és a regionális stabilitásról szóló megállapodást tartalmazza, az 1A melléklet rendelkezik a nemzetközi katonai jelenlétről is. ${ }^{149}$ (A katonai rendelkezések első mellékletbe foglalása is alátámasztja korábbi állításunkat, miszerint ekkor - a háború lezárása után közvetlenül - elsősorban a békés viszonyok megteremtése volt a cél.) A dokumentum rendelkezéseinek értelmében az UNPROFOR helyébe 19995. december 16-ától az ún. Végrehajtó Erők (Implementation Force - IFOR) ${ }^{150}$ léptek, amelyek az ENSZ BT felhatalmazásával jöttek létre, NATO- és nem NATO-tagállamok egyaránt hozzájárultak a felállításukhoz, ${ }^{151} \mathrm{~s}$ a NATO egységes irányítása alatt müködtek. Az IFOR a NATO addigi legnagyobb létszámú kontingensét mozgósító vállalkozás volt, a térségbe települt erők létszáma 60 ezer föt tett ki.

A melléklet az IFOR feladatát alapvetően a daytoni megállapodás katonai rendelkezéseinek végrehajtásában jelölte meg, vagyis mindenekelőtt a fegyverszünet, a kivonulás és a fegyverek begyüjtésének ellenőrzésében, valamint a boszniai légtér ellenőrzésében. A békefenntartó erők feladatává tette a megállapodás azt is, hogy „a kijelölt elsődleges feladatok és a rendelkezésre álló források függvényében” a többi, térségben tevékenykedő nemzetközi szervezetnek nyújtson segítséget munkájuk

\footnotetext{
1481995 márciusában az UNPROFOR-erők létszáma 38599 katona, 803 rendőr, 2017 civil nemzetközi és 1615 helyi alkalmazott volt. (UN Peacekeeping Operations - UNPROFOR [é. n.])

149 A daytoni megállapodás 1. számú melléklete rendelkezik továbbá az ellenségeskedések megszüntetéséről, az idegen harcoló felek (a szomszédos és más államokból ideérkező tanácsadók, szabadságharcosok, kiképzők, önkéntesek) 30 napon belül történő kivonulásáról, a boszniai harcoló alakulatok leszerelésének (redeployment) és az IFOR bevonulásának ütemezéséről, valamint a fogolycserékről. (Daytoni megállapodás [1995] 1. sz. melléklet)

${ }^{150}$ Az IFOR-erők létrehozásának jogi alapját az ENSZ Biztonsági Tanácsának 1031. sz. határozata adta meg. A katonai hadművelet kódneve Operation Joint Endeavour („közös törekvés”) volt. (S/RES/1031 [1995])

151 A hadmüveletben mindegyik NATO-tagállam részt vett, Izland, melynek nincs hadereje, orvosi kontingenssel volt jelen. A részt vevő nem NATO-tagállamok közül bizonyos államok a Békepartnerségi Program tagjai voltak (Albánia, Ausztria, Csehország, Észtország, Finnország, Lengyelország, Lettország, Litvánia, Magyarország, Oroszország, Románia, Svédország, Ukrajna), de részt vettek olyan országok is, amelyek semmilyen módon nem intézményesítették addig kapcsolataikat a szervezettel (Egyiptom, Jordánia, Malajzia, Marokkó). Oroszország részvétele 1996 januárjától a misszióban kiemelkedő jelentőségünek tekinthető. (Wentz [1997] pp. 27-28.)
} 
végzéséhez (különösen a humanitárius segítségnyújtás területén, de külön kiemeli a dokumentum a választásokat és a menekültek biztonságos visszatérését is), ${ }^{152} \mathrm{~s}$ hogy felügyelje az aknaszedési folyamatot is. A feladatok meghatározása fentiek alapján nyilvánvalóan nem túlságosan részletgazdag, ${ }^{153} \mathrm{~s}$ a dokumentum szövegezésénél is tisztában voltak azzal a készítők, hogy az ellátandó feladatok köre az idők során változhat és bővülhet (vagy éppen szükülhet) a körülmények változása függvényében. A kellő rugalmasságot az IFOR számára úgy biztosították, hogy az Észak-atlanti Tanácsnak lehetővé tették a későbbiekben az IFOR újabb feladatainak kijelölését (Daytoni megállapodás [1995] 1. sz. melléklet IV/4. cikk). Az 1. számú melléklet értelmében az IFOR jogosult volt megfigyelni, ellenőrizni és vizsgálni bármely feltehetően katonai tevékenységet végző szervezetet és annak tevékenységét, akadálytalanul mozoghatott a boszniai felségjog alatt álló szárazföldön, levegőben és vízen, és rendelkeztek arról is, hogy nem terheli felelősség a feladatai ellátása során okozott károkért. A nemzetközi katonai jelenlét irányításában fontos szerepe volt az Egyesített Katonai Bizottságnak (Joint Military Commission), amely az IFOR-erök föparancsnokának vezetésével teret biztosított az IFOR-parancsnokság alatt tevékenykedő nemzeti kontingensek vezetői számára a konzultációra és arra, hogy javaslatokat tegyenek a föparancsnoknak a misszió müködésére vonatozóan. A testület munkájában részt vehetett a nemzetközi polgári igazgatás vezetője, a főmegbízott is. Két dologra érdemes ehelyütt felhívni a figyelmet. A dokumentum egyfelől nem rendelkezik arról, hogy a hágai törvényszék (ICTY) által körözött, háborús bünök elkövetésével vádolt személyek elfogásában miként kellene részt vennie az IFOR-nak. Másfelől azt is érdemes kiemelni, hogy a daytoni megállapodás alapján a nemzetközi békefenntartók irányítása és minden ügyben a végső döntés az IFOR föparancsnokának egyszemélyes felelőssége lett, abba nem szólhat bele egyetlen más nemzetközi szereplő sem. Ezzel a döntéssel teljes mértékben elkülönítették egymástól a nemzetközi polgári és katonai igazgatást. ${ }^{154}$

\footnotetext{
${ }^{152}$ Az érintett szervezetek: EBESZ, UNHCR, IPTF.

153 A daytoni megállapodáson túl a szintén ebben az időszakban elfogadott egyéb kötelező erejü dokumentumok (általában ENSZ BT határozatok) szabályozzák részletesebben a háború lezárása utáni viszonyokat, éppen ezért ezen dokumentumok a békemegállapodással mindig együtt értelmezendők. A dolgozatban ezekre a kiegészítő dokumentumokra mindig utalunk, s jelezzük pontos fellelhetőségüket is.

${ }^{154}$, ,...] a fömegbízott nem gyakorol semmiféle hatalmat az IFOR felett és semmilyen módon nem avatkozhat bele a katonai műveletek végrehajtásába vagy az IFOR utasítási láncába”, a civil és a katonai igazgatás között a kommunikáció az együttmüködést és a konzultációt foglalja magába. (Daytoni megállapodás [1995] 10. melléklet II/9. cikk)
} 
Az IFOR egyéves mandátumának lejártakor (1996 decemberében) befejezte tevékenységét, amelyet sikeresként értékelhetünk. Ennek a sikernek minden bizonnyal az egyik feltétele az volt, hogy az elsődleges és a másodlagos célok egyértelmü elkülönítése - és viszonylag szükre szabása - hozzájárult a világos cél- és feladatmeghatározáshoz. Az IFOR tevékenységét tekintve inkább klasszikus értelemben vett békefenntartó erőként volt jelen a térségben. Szintén fontos tényező volt, hogy az ENSZ Alapokmányának VII. fejezete jelentette a katonai misszió müködésének legitim bázisát, s ez meglehetősen szélesre szabta az erőszak alkalmazásának lehetőségét az Észak-atlanti Szövetség számára, (Šelo Šabić [2005] p. 161.) amely a hatékony eröalkalmazás szempontjából egyébként is hitelesebb, mint az ENSZ békefenntartó erői ('́gy a korábbi UNPROFOR is).

A nemzetközi igazgatás első két évében (1996-1997) tehát lényegében a biztonságos környezet kiépítése volt a legfőbb feladat, amely elökészítette a terepet a civil igazgatás feladatainak beteljesítéséhez, amely már az állam stabil müködésének biztosítására és a demokratikus intézményrendszer kiépítésére fókuszált - ez egyben a nemzetközi igazgatás második szakaszának kezdetét is jelentette. A nemzetközi biztonsági jelenlét fenntartása természetesen az első szakasz lezárulása után is indokolt volt, a feladatok azonban a körülmények változásához igazodva módosultak. Amint azt említettük, egyéves müködése után 1996 decemberében az IFOR-erők mandátuma lejárt, helyükbe az ún. Stabilizációs Erők léptek (Stabilization Force - SFOR), ${ }^{155}$ amelynek nevéből is kiolvasható a megváltozott mandátum: itt már nem a daytoni megállapodásba foglalt és a válság lezárásához szükséges katonai rendelkezéseinek végrehajtásáról van szó, hanem sokkal inkább a békés viszonyok megszilárdításáról és a civil igazgatás hatékony támogatásáról.

Az SFOR ${ }^{156}$ az IFOR-hoz hasonló legitimációs bázissal bíró (ENSZ-felhatalmazás az Alapokmány VII. fejezete alapján), NATO- és nem NATO-tagállamokat ${ }^{157}$ is tömörítő,

\footnotetext{
155 A mủvelet katonai kódneve Operation Joint Guard volt az első szakaszban (1996. december 21. 1998. június 19.), és Operation Joint Forge a másodikban (1998. június 20. - 2004. december 2.).

156 Az SFOR létrehozása az 1088. sz. BT határozat elfogadásával történt (1996. december 12-én), mandátumának kezdete 1996. december 20., hossza pedig a dokumentum szerint 18 hónap. (S/RES/1088 [1996])

157 A műveletben minden NATO-tagállam részt vett, a nem-tagállamok közül pedig: Albánia, Ausztria, Argentína, Chile, Bulgária, Egyiptom, Észtország, Finnország, Írország, Lettország, Litvánia, Malajzia, Marokkó, Oroszország, Románia, Szlovákia, Szlovénia és Svédország. (A felsoroltak közül még az SFOR mandátumának lejárta előtt - 2004 márciusában - csatlakozott a Szövetséghez Bulgária, Észtország,
} 
de a NATO egységes irányítása alatt álló többnemzetiségű katonai erő volt, azonban feladatait tekintve több szempontból különbözik elődjétől, s érzékelhetően elmozdult a békefenntartástól a békevégrehajtás irányába. Elsődleges feladataként az SFOR a béke megszilárdításához szükséges biztonságos környezetet volt hivatott szavatolni, speciális feladatai pedig az alábbiak voltak: az ellenségeskedések kiújulásának és a békét fenyegető cselekményeknek a megakadályozása; olyan környezet biztosítása, amelyben a békefolyamat előrehaladhat; lehetőségeihez mérten szelektív támogatás biztosítása a civil igazgatásban részt vevő nemzetközi szervezeteknek (OHR, EBESZ, IPTF, EUPM, UNHCR. ICTY). Az SFOR elődjénél jóval kisebb létszámú kontingenssel kezdte meg munkáját, mandátumának kezdetén 32000 katona vett részt a müveletben, ez 2002 decemberére (a mandátum végére) mintegy 12000 före csökkent. (NATO SFOR [é. n.]) Mint ahogyan az a nemzetközi jelenlét katonai aspektusára általában jellemző, az SFOR is sikeres vállalkozásnak tekinthető. A többnemzetiségü katonai erők jelenléte érzékelhetően csökkent ugyan Boszniában az SFOR fennállásának idején, ez azonban annak köszönhető, hogy valóban sikerült a békés viszonyok megteremtése úgy, hogy egyre kevésbé volt szükség az erőteljes katonai jelenlétre. Az IFOR-ra jellemző visszafogottsághoz képest azonban az SFOR jóval aktívabb volt a rendezés civil aspektusainak előmozdításában - pontosabban az e területen tevékenykedő nemzetközi szervezetek munkájának segítésében -, nyilvánvalóan annak köszönhetően, hogy a nemzetközi igazgatás fókusza ekkorra (1997 után) eltolódott a biztonság elsődleges prioritásként kezelésétől a civil feladatok megvalósítása felé. Ez a változás leglátványosabban az ICTY-nal való együttmüködésben mutatkozott meg, hiszen az SFOR fennállásának ideje alatt 1997 júniusától (Belloni [2007] p. 24.) 27 személyt vett őrizetbe (hárman pedig menekülés közben életüket vesztették). (NATO SFOR [é.n.]) (Blockmans [2007] p. 85.)

Két lényeges történést érdemes még megemlíteni az SFOR müködésének idejéről: az egyik az amerikai részvétel változása, a másik pedig a civil-katonai együttmüködés erősödése. Az Amerikai Egyesült Államok jelenléte a boszniai nemzetközi katonai igazgatásban mindig is számottevő volt, s 1995-ben a rendezés ezen területén alapvetően az USA diktálta a feltételeket. Az amerikai részvétel már 1995-ben is nagy

Lettország, Litvánia, Románia, Szlovákia, Szlovénia.) Ausztrália és Új-Zéland az Egyesült Királysággal kötött megállapodás alapján kapcsolódott be a misszió múködtetésébe. (NATO SFOR [é. n.]) (Šelo Šabić [2005] p. 165.) 
vitákat váltott ki a belpolitikai színtéren, az amerikaiaknak a kilencvenes évek első felében szerzett afrikai negatív békefenntartói tapasztalatai (szomáliai fiaskó) csak felerősítették a Vietnam óta fennálló félelmeket, s - ahogyan találóan Richard Holbrooke nevezte - a Vietmalia-szindróma (Holbrooke [1998] p. 219.) arra ösztönözte az amerikai felet, hogy lehetőleg ne köteleződjön el hosszú távon a boszniai szerepvállalás mellett. Ennek lett az egyik következménye az IFOR-nak a daytoni megállapodásban rögzített egyéves mandátuma, annak világos, de meglehetősen szükre szabott és jól körülhatárolt feladatköre, valamint az a tény, hogy pl. az ICTY-nal való együttmüködés részeként explicit módon nem tették az IFOR kötelességévé a háborús bünökkel gyanúsítható személyek elfogását, csak az ehhez szükséges felhatalmazást adták meg számára. (Belloni [2007] p. 21.) Az amerikai részvétel mindezek ellenére relatíve jelentős maradt (az USA mindvégig a legnagyobb létszámú kontingenst adta az IFOR-ban és az SFOR-ban is), bár a létszámuk abszolút értelemben jelentősen csökkent (az 1995-ös 20000 főről 2002-re 3 000-re, ami az amerikai részvételi aránynak az összlétszám egyharmadáról egyhatodra való leszállítását jelenti). (Šelo Šabić [2005] p. 165$.

Az SFOR ideje alatt történt másik jelentős elörelépés, hogy 1998-ban létrejött Boszniában a civil és a katonai igazgatás koordinációját segítő szerv, a CIMIC (CivilMilitary Cooperation). A NATO CIMIC-doktrínáját a kilencvenes években fejlesztette ki, első alkalmazási területe pedig a Balkán volt. A cél az, hogy a nemzetközi katonai erők és a civilek - ideértve a civil lakosságot, a civil igazgatásban tevékenykedő nemzetközi és helyi szerveket, valamint NGO-kat - között teremtsen fórumot a párbeszédhez, s csatornát az információk áramlásához. A CIMIC képviselői ${ }^{158}$ jelen vannak a térségben tevékenykedő legfontosabb nemzetközi szervezetekben, ${ }^{159}$ és ún. funkcionális csoportjaik révén tevékenységük kiterjed az alábbi területekre: infrastruktúra, humanitárius segítségnyújtás, gazdaság, kultúra és oktatás, igazgatás, közügyek. A CIMIC létrehozását az a felismerés indokolta, hogy az IFOR müködésének idején a nemzetközi katonai erő csak korlátozott mértékben - és feladatai között nem prioritásként, hanem másodlagosként kezelve ezt a tevékenységet - nyújtott segítséget a

\footnotetext{
${ }^{158}$ A CIMIC alkalmazottai alkotják a Combined Joint Civil-Military Cooperation Task Force (CJCMTF) elnevezésű csoportot, a székhely Szarajevó. (NATO SFOR CIMIC [é. n.])

${ }^{159}$ OHR, Világbank (IBRD), UNHCR, EBESZ, IPTF. (NATO SFOR CIMIC [é. n.])
} 
civil igazgatás intézményeinek. A CIMIC létrehozása után több lehetőség nyílott a közös célok megvalósítása során a hatékony együttmüködésre a két szféra között.

A kilencvenes évek végére egyre erősödött az a felvetés, miszerint a civil komponens előtérbe kerülésével a katonai jelenlétet minimálisra kellene szorítani, esetleg teljesen kivonulni. Ezen felvetések hátterében két motívumra érdemes odafigyelni: az egyik, hogy a nemzetközi adminisztrációban részt vevő államokat csalódással töltötték el a boszniai rendezés szaporodó kudarcai. Ekkorra már jól látszottak ugyanis azok a területek, ahol az elöremozdulás vajmi kevés eséllyel kecsegtetett (mindenekelött az alkotmányos, választási és oktatási reformok megrekedése; az etnikumok közti viták élesedése, a nemzeti-etnikai alapon felépült pártstruktúra látszólagos megingathatatlansága stb.), (Solioz [2005] p. 121.) s nemcsak a helyi szereplők együttműködési hajlandóságának hiánya, hanem a daytoni rendezésből fakadó béklyók is akadályozták az eredményességet. A másik ok, miért a katonai jelenlét csökkentése felvetődött, az amerikai álláspontban keresendő. Az USA 2001-től - annak ellenére, hogy Bush elnök jóval elkötelezettebb volt a balkáni katonai jelenlétet illetően, mint elődje, Clinton - kénytelen volt átértékelni a prioritásokat 2001. szeptember 11. után: a terrorellenes háború és az afganisztáni szerepvállalás előtérbe kerülése komoly lökést jelentett a boszniai kivonulás szorgalmazásában, az iraki részvétel pedig ezt tovább fokozta. (ICG [2001] p. 4.) Az USA a háború lezárása óta a nemzetközi katonai igazgatásban játszott kiemelkedő, valójában főszerepet, a civil igazgatást addig is átengedte az európai szervezeteknek és államoknak, 2001 után azonban a biztonsági jelenlétéről is nagyrészt lemondott. ${ }^{160}$ Ezt a 2004-es isztambuli NATO-csúcson meg is erősítették a szervezet döntéshozói, amikor döntöttek az SFOR megszüntetéséröl. (NATO [é. n./a]

Mindeközben az Európai Unió egyre határozottabban elkötelezte magát a Balkán irányába, így találkozott az amerikai kivonulási szándék az erősödő európai szerepvállalási hajlandósággal. (ICG [2004]) Az EU részéről a koszovói háború ideje alatt megindított stabilizációs és társulási folyamat 2003 nyarán, a thesszaloniki tanácsülésen, újabb vállalással egészült ki: itt az uniós állam- és kormányfők kijelentették, hogy a Balkán államainak jövője az Unióban van, vagyis a jövőben az EU

\footnotetext{
${ }^{160}$ A pontosság kedveért: Boszniáról van szó ehelyütt, a koszovói KFOR-erőkben az amerikai jelenlét továbbra sem csökkent jelentős mértékben.
} 
tagjainak sorában kész üdvözölni a térség államait. A balkáni szerepvállalás az EU részéről a civil, azon belül is elsősorban a gazdasági jellegü segítségnyújtásra korlátozódott, ez változott meg 2003-2004-ben, amikor az EU először rendőri, majd katonai kontingenst vezényelt Boszniába. Utóbbi keretében 2004. december 2-án a Boszniába települt az Európai Unió EUFOR Althea ${ }^{161}$ missziója. amely folytatta elődeinek, az IFOR-nak és az SFOR-nak még a daytoni rendezés során megalapozott mandátumát. Az EUFOR-t tanácsi határozattal hozták létre, ${ }^{162}$ majd az ENSZ BT 1575ös határozatában megadta szükséges felhatalmazást is a mintegy 7000 fös - EU- és nem EU-tagállamokból álló -, ${ }^{163}$ az ENSZ Alapokmánya VII. fejezete alapján és a daytoni megállapodás szellemében tevékenykedő kontingens felállításához. (Keohane [2009] p. 213.) Az EUFOR megjelenése nem jelentette ugyanakkor a NATO-teljes kivonulását Boszniából, bizonyos feladatok ellátására ${ }^{164}$ alacsony létszámú kontingenst még állomásoztat a NATO Szarajevóban. A NATO és az EU közti feladatmegosztásról - a párhuzamosságok elkerülése érdekében - a 2003. március 17-én a Berlin Plusz megállapodásban ${ }^{165}$ rendelkeztek. (Lindley-French [2003])

\footnotetext{
${ }^{161}$ Althea görög mitológiai nőalak volt, a görög szó jelentése: gyógyító.

${ }^{162}$ A tanácsi rendelet a következő volt: (Európai Unió Tanácsa) Council Decision (2004/803/CFSP) of 25 November 2004 on the launching of the European Union military operation in Bosnia and Herzegovina. Forrás: Official Journal of the European Union, L 353, Brussels, 27 November 2004, Art. 1.Ez kiegészült még a közös akcióról szóló döntéssel: (Európai Unió Tanácsa) Council Joint Action (2004/570/CFSP) of 12 July 2004 on the European Union military operation in Bosnia and Herzegovina. Forrás: Official Journal of the European Union, L 252, 28 July 2004. (Knauer [2011] p. 5.)

${ }^{163}$ A jelenleg részt vevő EU-tagállamok (19 ország): Ausztria, Bulgária, Csehország, Egyesült Királyság, Finnország, Franciaország, Görögország, Hollandia, Írország, Lengyelország, Luxemburg, Magyarország, Németország, Olaszország, Románia, Spanyolország, Svédország, Szlovákia, Szlovénia. Nem EUtagállamok (5 ország): Albánia, Chile, Macedónia (FYROM), Svájc, Törökország. Mindösszesen 24 ország. (EUFORBiH [é. $n . / a$ ]) Az EUFOR fennállása alatt 34 volt az egy időben a misszióban tevékenykedő legnagyobb számú állam. (Keohane [2009] p. 215.)

164 A NATO elsődlegesen a boszniai védelmi reformok terén nyújt segítséget a balkáni államnak, bizonyos feladatokat pedig az Európai Unióval együttmüködve lát el, ezek: a terrorizmus-ellenes küzdelem, hírszerzés és a háborús bünökkel vádolt személyek elfogása. (NATO [é. n./b])

${ }^{165}$ A Berlin Plusz együttműködés tartalmáról ld. az alábbi dokumentumot az Európai Unió Tanácsának honlapján: EU-NATO: The Framework for Permanent Relations and Berlin plus. (Európai Unió Tanácsa [2003])

A Berlin Pluszként ismert fogalom valójában megállapodások gyüjteményére utal, pillérei a következő: az EU számára hozzáférést biztosít a NATO műveleti tervezéséhez; az EU részére meghatározott NATOeszközök és képességek rendelkezésre bocsátása; EU-múveletek esetén a NATO Európai Főparancsnokságának igénybevétele; a NATO védelmi tervezőrendszerét az EU-müveletekhez igazítják a rendelkezésre álló erők mértékének megfelelően. Maga a kifejezés (Berlin Plusz) pedig arra utal, hogy a NATO és az EU közti együttmüködés gyökerei az 1996 tavaszi NATO külügyminiszteri ülésre vezethetőek vissza, amikor a döntéshozók megállapodtak arról, hogy az Európai Biztonsági és Védelmi Identitás kidolgozásához a NATO forrásait rendelkezésre bocsátják. Ezt a találkozót Berlinben tartották, de még éveket kellett várni, hogy tényleges lépések szülessenek a kooperáció előmozdítására. A Berlin Plusz folyamat mindenképpen mérföldkőnek tekinthető a konfliktuskezelés területén megvalósuló együttmüködési folyamatban. (Lindley-French [2003])
} 
Az EUFOR mandátumában létrehozásakor katonai és támogató feladatokat különítettek el. A katonai feladatok a következők: masszív katonai jelenlét az ellenőrző, elrettentő, és ha szükséges, megelőző funkció ellátásához; a biztonságos és nyugodt környezet megteremtése, valamint az OHR munkájának támogatása és a békefolyamat hátráltatására irányuló erőfeszítések megakadályozása; hírszerzés; a daytoni megállapodásban rögzített bizonyos feladatok folytatása, úgymint légtér-ellenőrzés, az aknamentesítési folyamatban és a fegyverek begyüjtésében tanácsadás. A támogató feladatokat az alábbiakban határozták meg: az OHR támogatása misszió-végrehajtási tervének (Mission Implementation Plan - MIP) megvalósításában, ami elsősorban a szervezett bünözés elleni harc segítését jelenti a szervezet logisztikai és műveleti kapacitásainak felhasználásával; a védelmi szektor reformjának és intézményeinek támogatása; segítségnyújtás az ICTY-nak a háborús bünökkel vádolt személyek felkutatásában; a nemzetközi közösség helyszínen dolgozó alkalmazottainak evakuálása, ha szükséges. (Knauer [2011] p. 10.)

Az EUFOR fennállásának ideje alatt mandátuma fokozatosan változáson ment keresztül, ennek alapján három szakaszt különböztethetünk meg az EUFOR működésének kezdete óta. Az első szakaszban (2004 és 2007 között) a fent felsorol prioritások és jellemző karakterisztikák alapvetően megmaradtak, ${ }^{166}$ a második szakaszban (2007 és 2010 között) azonban azzal párhuzamosan, hogy az EUFOR-erők létszámát egy tanácsi döntés ${ }^{167}$ értelmében csökkentették (5 500-ről 500 före), a helyszínen maradó erők feladatai is némiképp átstrukturálódtak. ${ }^{168}$

\footnotetext{
${ }^{166}$ Az EUFOR felépítése egy három részből álló struktúrát mintáz, az egyes részek a következők: 1) eredetileg három Többnemzetiségű Mủveleti Erő (Multinational Task Forces - MNTFs) Mostar, Banja Luka és Tuzla központokkal, amelyek a 2007-es haderöcsökkentés nyomán egyesültek, s helyükbe a szarajevói székhelyü Többnemzetiségü Manőver Zászlóalj (Multinational Manoeuvre Battalion MNBN) lépett; 2) Integrált Rendőri Egység (Integrated Police Unit - IPU); 3) Összekötő és Megfigyelö Csoportok (Liaison and Observation Teams - LOTs); 4) 2010-töl negyedik komponensként csatlakoztak az első háromhoz a Mobil Kiképző Csoportok (Mobile Training Teams - MTTs). (Knauer [2011] p. 15.)

${ }^{167}$ A tanácsi dokumentum a következö volt: (Európai Unió Tanácsa) Press Release - 2789th Council meeting - General Affairs and External Relations, Council Doc. 6756/07 (Presse 39), Brussels, 5 March 2007

${ }^{168}$ Ebben az időszakban (2008-2009-ben) heves viták zajlottak az uniós tagállamokban, hogy egyáltalán fenn kell-e tartani a katonai jelenlétet Boszniában. A kivonulást támogatók - Franciaország, Spanyolország és Finnország - a belső stabilitás elégséges voltát és politikai-financiális szempontokat hangoztattak, az ellenzők - Ausztria, az Egyesült Királyság, Hollandia és Szlovákia - pedig azzal érveltek, hogy a kivonulás járhat azzal a következménnyel, hogy a destabilizáló erők meglódulnak, és fegyveres konfliktusba torkollanak a kiújuló ellenségeskedések, amelyek pedig nemcsak Bosznia, de az egész Balkán regionális stabilitását veszélyeztetik. (Keohane [2011] p. 2019.)
} 
A változást a boszniai változások generálták: hosszas meddő várakozás után létrejött a közös hadsereg és rendőrség, amely ugyan nem müködött kifogástalan hatékonysággal, de lehetővé tette, hogy a nemzetközi katonai jelenlét lecsökkenjen és teret engedjen a helyi szerveknek a biztonság fenntartásában. A politikai instabilitás azonban fennmaradt az országban - ennek egyik jele volt a koszovói függetlenség 2008. februári kinyilvánítását követő feszült helyzet Boszniában -, (Dobbins [2008] p. 158.) a mandátum alapvetően nem változott, legfeljebb a hangsúlyok tolódtak el kissé, az EUFOR helyi erőinek végrehajtó jogosítványait azonban nem csökkentették arra való tekintettel, ha esetleg szükségessé válna a nemzetközi fegyveres beavatkozás a feszültségek fokozódása esetén. A harmadik szakasz 2010-ben kezdődött és máig is tart, a mandátum ebben a szakaszban jelentősen módosult: ${ }^{169}$ a végrehajtó jogosítványok minimálisra csökkentek és előtérbe került a kapacitásépítés és a képzésben való segítségnyújtás. (Knauer [2011] pp. 10-12.) A kontingens nagysága ebben az utolsó szakaszban nem sokat változott, miután elérte azt a kritikus határt, ahol még hatékony és a boszniai nép számára hiteles erőként maradhat a térségben. Jelenleg az EUFOR erők létszáma kb. 1200 fö. (EUFORBiH [é. n./b])

Az EUFOR sikeres misszióként értékelhető, katonai és operatív szempontból mindenképp. Az Európai Uniónak sikerült legyőznie azt az ellenérzést, amit a boszniai emberek kezdetben tápláltak irányába, mivel úgy vélték, hogy - tapasztalat hiányában az uniós erők nem lehetnek olyan hatékonyak, mint a NATO katonái. Mandátumának lejártakor azonban az SFOR állományának kb. 80\%-a európai nemzetek tagjaiból állt, (Bertin [2008]. p. 64.) s a külső államok a váltás után is a térségben kívántak maradni kontingensükkel: a személyi állomány tekintetében tehát a katonák nagy része csak lecserélte SFOR egyenruháját EUFOR uniformisra. (Dobbins [2008] p. 152.) Az EUFOR megőrizte az SFOR határozott és robusztus arculatát is, jól kommunikált a helyi lakossággal és a vezetőkkel, s aktívan bekapcsolódott a szervezett bünözés elleni harcba is - így a kezdeti bizalmatlanságot sikerült felszámolnia. (Knauer [2011] p. 18.)

\footnotetext{
169 A rendelkező tanácsi döntés: (Európai Unió Tanácsa) Press Release - 2992nd Council meeting Foreign Affairs, Council Doc. 5686/10 (Presse 10), Brussels, 25 January 2010
} 


\subsubsection{Nemzetközi rendöri erök}

A nemzetközi katonai jelenlét volt a biztonságos és békés viszonyok megteremtésének legföbb záloga, ez azonban ki kellett, hogy egészüljön azzal, hogy az állam belső rendjének és a jog érvényesülésének egyik garanciájaként müködő rendőrség helyzetét is rendezik. A daytoni megállapodás 11. melléklete a Nemzetközi Rendőri Erök ( $U N$ International Police Task Force - IPTF) felállitásáról szólt, ez volt a nemzetközi biztonsági jelenlét másik fontos pillére, ez azonban - szemben a katonai pillérhez tartozó IFOR-ral - a nemzetközi igazgatás civil pilléréhez tartozott. Az IPTF vezetője az ún. biztos (commissioner) volt, aki a fömegbízott irányítása alatt áltt, $\mathrm{s}$ mind a Közös Polgári Bizottság, mind pedig a Közös Katonai Bizottság ülésein részt vehetett. Az IPTF feladata a daytoni megállapodás szerint a következő volt: a jogkikényszerítés állandó ellenőrzése, ideértve a felelős intézmények, struktúrák és folyamatok figyelemmel kísérését; ugyanezen a területen tanácsadás és tréningek szervezése; a közrendre veszélyt jelentő fenyegetések feltérképezése és az illetékes szerveknek tanácsadás a kezelésüket illetően; a boszniai kormányzati szerveknek javaslattétel a jog kikényszerítésére létrehozott hatékony intézményi struktúrára vonatkozóan. Az IPTF tehát nem funkcionált rendőrségként - hiszen végrehajtó jogosítványokkal nem rendelkezett -, legföbb feladata a hatékony rendőrségi struktúra kiépítésében nyújtott segítség volt, a nemzetközi struktúrában pedig az ENSZ UNMBiH missziójának részét képezte. Amikor 2002. december 31-én az UNMBiH mandátuma lejárt, az IPTF is megszünt, feladatait az Európai Unió rendőri missziója vette át.

Az Európai Unió Rendőri Missziója (European Union Police Mission - EUPM) az Unió történetében az európai biztonság- és védelempolitika (European Security and Defence Policy - ESDP) első - a polgári válságkezelés területén végrehajtott művelete, ${ }^{170}$ amely EU-tagállamok és nem EU-tagokat is tömörítve ${ }^{171} 2003$. január 1. és 2012. június 30. között müködött Bosznia-Hercegovina területén, kezdetben hároméves mandátummal, amelyet többször meghosszabbítottak. Azzal a céllal hozták létre, hogy hozzájáruljon egy fenntartható, professzionális, többnemzetiségü, és a legjobb európai

\footnotetext{
${ }^{170}$ Az EUPM-et létrehozó tanácsi döntés a közös akcióról: (Európai Unió Tanácsa) Council Joint Action on the European Police Mission, 2002/210/CFSP of 11 March 2002 (Európai Unió Tanácsa [2002])

${ }^{171}$ Az EUPM működtetéséhez az EU-tagállamokon túl az alábbi országok is részt vettek: Izland, Kanada, Norvégia, Svájc, Törökország, Ukrajna. (EUPM [é. n.])
} 
és nemzetközi gyakorlatoknak megfelelően müködő boszniai rendőrség létrehozásához. (Belloni [2007] p. 154.) Elődszervezetéhez, az ENSZ IPTF rendőri erőihez képest az EUPM jóval alacsonyabb létszámú személyi állománnyal - az IPTF múködése alatti legnagyobb létszáma 2000 fö volt, az EUPM-é 500 fö - és szerényebb mandátummal rendelkezett. Az EUPM-nek nem voltak végrehajtó jogosítványai (nem volt pl. joga letartóztatni vagy bünvádi eljárást kezdeményezni), feladata a mentoráló és monitoringtevékenységen túl - a végrehajtó jogok hiányában nehezen értelmezhető - vizsgálódás volt, (Šelo Šabić [2005] p. 248.) utóbbi a boszniai rendőrség vezetői és operatív képességeinek ellenőrzését jelentette, s a rendőri állomány közép- és felsővezetői rétegét vette célba. Lényeges különbség tehát az IPTF-hez képest, hogy amíg az a legsürgősebb háború utáni tennivalókra fókuszálva a rendőri állomány tagjainak nyújtott képzéseken túl nem tüzte ki célul a rendőrség megreformálását, addig az EUPM-nek éppen ez volt a célja. (Mühlman [2008] p. 48.)

Az EUPM-nek müködése során számos problémával kellett szembenéznie. A szervezet kifejezetten nehezen állt fel, a felszerelések, gépek beszerzése a bonyolult uniós eljárások miatt hosszadalmas volt, a személyi állomány gyengesége miatt pedig fennállása alatt sok kritika érte az EUPM-et. Szintén kihívást jelentett a müködési tervek elkészítése során annak eldöntése, hogy - egységes uniós gyakorlat híján - mit tekintsenek követendő példának (vagy ha úgy tetszik, ,jó gyakorlatnak”). A megoldás végül az lett, hogy bizonyos EU-tagállamok szakértői érkeztek Boszniába és saját nemzeti sztenderdjeiknek megfelelően képezték ki egy-egy szakterület helyi felelőseit. $\mathrm{Az}$ eddig felsoroltaknál jóval nehezebb megoldandó problémát jelentett a Bosznia müködéséből és a helyi viszonyokból fakadó kihívások sora. Az államigazgatás politikai-etnikai törésvonalak mentén polarizált jelleg egyébként is nehezítette a reformok előrehaladását, de a rendőrség megreformálása - amire az EUPM vállalkozott - kétségtelenül az egyik legkeményebb diónak bizonyult. A rendőrség a háború alatt fontos szereplője (aktív végrehajtója) volt az etnikai tisztogatásoknak, ${ }^{172}$ a háború végén pedig három rendőrség volt az országban (a bosnyák, a szerb és a horvát), amelyek csak

\footnotetext{
${ }^{172}$ A háború során nagy problémát jelentett, hogy annak kezdetén a három szembenálló etnikumból kettőnek (a bosnyákoknak és a horvátoknak) nem volt saját hadserege. A szerbek voltak a legjobb helyzetben, mert a Jugoszláv Néphadsereg arzenáljának túlnyomó részét és a szerb dominanciájú hadsereg személyi állományának is jelentős részét megörökölték még a háború elején. A bosnyákok és a horvátok kezdetben fegyveres erejüket abból igyekeztek létrehozni, ami rendelkezésükre állt: a rendőrökből, a területvédelmi egységek tagjaiból, hozzájuk csatlakoztak az egyre szaporodó félkatonai szervezetek és milíciák tagjai.
} 
saját nemzettársaikat türték meg a testületekben, ráadásul számos, a rendőrség állományába tartozó személy követett el háborús bünöket a délszláv válság idején. A Föderációban a bosnyákok és a horvátok ugyan végül hajlandóak voltak egységes rendőri szervezetet létrehozni - ám az etnikai paritás következményeként jellemző decentralizáció példátlanul fragmentálttá tette a rendőrségi struktúrát a Föderációban -, a szerbek azonban hallani sem akartak a rendőrség átalakításáról. ${ }^{173}$ Tovább nehezítette a helyzetet, hogy a politikai szféra, a fegyveres erők és testületek, valamint a szervezett bünözés számos ponton összefonódott. (ICG [2005] p. 2-4.)

Azonban nem csupán a helyi viszonyok nehezítették az EUPM müködését: a hatáskörök világos megosztásának hiánya az EU másik Boszniában tevékenykedő missziójával, az EUFOR-ral is feszültségeket generált. Miután 2004 decemberében az EUFOR Althea megkezdte müködését, mintegy másfél évre volt szükség, hogy a két szervezet tevékenységében jelentkező átfedéseket kiküszöböljék. Az EUFOR ugyanis szintén rendelkezett saját rendőri erővel, az IPU-val (Integrált Rendőri Egység - Integrated Police Unit), amely a szervezett bünözés elleni fellépése során számos olyan akciót kezdeményezett, amelyről nem informálta sem a boszniai hatóságokat, sem pedig az EUPM-et, s ez bizonytalan és bizalmatlanságra is okot adó helyzetet teremtett: nem volt ugyanis világos, hogy mely nemzetközi szervezet és milyen mértékben felelős Boszniában a jog kikényszerítéséért. A helyzetet tovább bonyolította, hogy a két rivális nemzetközi szereplő mindegyike az Európai Unió ESDP-missziójaként tevékenykedett, azonban meröben más megközelítés jellemezte őket: míg az EUFOR végrehajtó jogosítványaival élve inkább keményebb katonai megközelítést alkalmazott, míg az EUPM - ilyen jogok hiányában - sokkal inkább a kapacitásépítésre és a helyi erők aktív bevonására épített (volna). (Merlingen [2009] p. 164) A konfliktus feloldására végül 1996-ban került sor, amikor egy tanácsi döntés ${ }^{174}$ nyomán rendezték a két szervezet hatásköri és illetékességi viszonyait a szervezett bünözés elleni tevékenységük kapcsán. A döntés lényege, hogy az EUPM lett az „ügy gazdája”, az EUFOR pedig csak

\footnotetext{
${ }^{173}$ A Föderációban a decentralizáció miatt a kantonok önállóan irányították minisztériumaikon keresztül helyi rendőri erőiket, mindenhol helyi jogszabályok alapján folyt a bünüldözés, az igazságszolgáltatás és a büntetés-végrehajtás. A Republika Srpska-ban az ottani szabályok érvényesültek, s külön rendörsége volt Brčkónak is. Így összesen 13 különböző rendőri testület müködött Boszniában, ami a költségvetési kiadások tetemes részét emésztette fel (kb. 10\%-ot). (ICG [2005] p. 2.)

${ }^{174}$ A szóban forgó döntés: (Európai Unió Tanácsa) Common Operational Guidelines for EUPM-EUFOR support to the fight against organised crime, Council Doc. 10769/06, Brussels, 21 June 2006 (Európai Unió Tanácsa [2006])
} 
korlátozottan, támogató jelleggel, az EUPM-mel való egyeztetést követően cselekedhetett. (Knauer [2011] p. 10.)

Amint azt említettük, az EUPM 2012. június 20-ig működött Boszniában, megítélése összességében kettősnek mondható. Eredményei közé kell sorolnunk, hogy a rendőrség professzionálisabbá tétele terén fontos eredményeket ért el (ilyenek pl. az elszámoltathatóság; a kevésbé diszkriminatív rekrutálás és humántőke-menedzsment; a bünügyi helyszínbiztosítás; valamint a nyomozási és törvényszéki kapacitások és szakértelem fejlesztése), jó néhány strukturális problémát azonban nem tudott megoldani. Munkáját sokáig akadályozta a rendőrségi reform késlekedése, s amíg az ahhoz szükséges jogszabályokat nem fogadta el a boszniai törvényhozás, az EUPM tevékenysége is csak korlátozott maradhatott. A 2008-as reform azonban nem a várakozásoknak megfelelő eredményt hozott: az eredeti elképzelésekkel szemben csak felvizezett, és a hatékony müködést továbbra is gátló, kompromisszumoktól terhes megoldás született. ${ }^{175}$ (Merlingen [2009] pp. 167-170.) Az EUPM sikertelenségét azonban nem magyarázhatjuk kizárólag a körülmények sajnálatos összejátszásával, a célok beteljesítését a személyi állomány felkészültségében helyenként tapasztalható hiányosságok és a finanszírozási nehézségek is gátolták, mely utóbbi elsősorban az ún. donorfáradtságnak volt köszönhető.

\footnotetext{
${ }^{175}$ A dolgozatnak nem célja, hogy a boszniai belső folyamatokat túlzott részletességgel ismertesse, ehelyütt röviden ismertetjük a rendőrségi reform kudarcának okait. 2005-ben fogalmazták meg azokat a feltételeket, amelyeket az Európai Bizottság támasztott a rendőrség megreformálása kapcsán, ezek. 1) a boszniai központi (szövetségi) intézmények szintjére kell helyezni minden, a rendőri erők költségvetését és a törvényi-szabályozási hátteret érintő döntést; 2) a rendőrségi körzeteket technikai és nem politikai szempontok alapján kell kialakítani, és lehetővé kell tenni a rendőrségnek, hogy műveletei során (ha szükséges), az entitások közti határvonalon túl is folytathassa az intézkedést; 3 ) a rendörséget érintő kérdésekben ki kell zárni a politikai befolyásolás lehetőségét. (Juncos [2011] p. 381.) Az EU nyilvánvalóvá tette: ezek a feltételei annak, hogy Bosznia továbbléphessen a stabilizációs és társulási folyamatban. Az akkori OHR (Lajčák) határozottan kiállt a reformok mellett, még erős végrehajtó jogosítványait is használta, hogy megegyezésre kényszerítse a feleket, a Republika Srpska heves ellenállása és a nemzetközi közösség meghátrálása azonban azt eredményezte, hogy az elvárásoknak csak egy része teljesült, amikor a Népek Háza 2008 áprilisában jóváhagyta az új törvényt. Az ok minden bizonnyal az volt, hogy az egyoldalú függetlenség kikiáltása nyomán kibontakozó koszovói feszültségek miatt a nemzetközi közösség nem akart újabb gócpontot generálni. Boszniában engedtek tehát, a szerbek elérték, hogy a rendőrségi körzetek nem keresztezik az etnikumközi határvonalat, Boszniával pedig az EU aláirta a stabilizációs és társulási megállapodást 2008. június 16-án. (Belloni [2009] pp. 364-365.)
} 


\subsection{Demokratikus intézményépítés}

Az Európai Biztonsági és Együttmüködési Szervezet (EBESZ, European Biztonsági és Együttmüködési Szervezet) a nemzetközi polgári igazgatás egyik kulcsintézménye lett, amennyiben a demokratizálás / demokratizálódás folyamatában a legjelentősebb szerepet játszotta az OHR mellett. Az EBESZ fö tevékenységének megfelelően mindenek előtt a konfliktusmegelőzésben ${ }^{176}$ és a konfliktus lezárását követő demokratikus újjáépítésben jeleskedik, a nemzetközi igazgatási struktúrákban ez utóbbinak van különös jelentősége.

A demokratikus intézményépítés komplex folyamatának egyik alapvető fontosságú mechanizmusát a választások jelentik, mivel elősegítik a helyi szereplők kiválasztását és bevonódását a helyi és a nemzetközi területi igazgatásba. A választások révén helyeződik át a hatalom és a felelősség egy része a kiválasztott helyi vezetőkre, egyúttal legitimitásuk is erősödik. (Caplan [2005] p. 120.) Ez persze ideális esetben van így, a választások nem mindig működnek egy válságból kilábalt társadalomban panaceaként, föként akkor nem, ha az adott közösség etnikai vagy egyéb törésvonalak mentén súlyosan megosztott, mint ahogyan a balkáni államoknál ez feltétlenül igaz.

Az EBESZ sokrétű mandátumában ${ }^{177}$ a „leglátványosabb” - és minden bizonnyal a legtöbb energiát felemésztő - szerepe a választások megszervezésében és lebonyolításában volt, ebben a fejezetben mi is erre koncentrálunk elsősorban.

\footnotetext{
${ }^{176}$ Az EBSZ fennállása óta több mechanizmust dolgozott ki a konfliktusok előrejelzésére vagy válságok kezelésére, ezek közül hármat érdemes megemlíteni. Az ún. bécsi mechanizmus keretében 1989-től a tagállamoknak lehetöségük van rögzített keretek között kérdéseket feltenni egy másik tagállam emberi jogi rezsimjével kapcsolatban, amelynek tagállamként kötelessége ezekre választ adni. A moszkvai mechanizmust 1991 óta alkalmazzák, s lényege, hogy minimum hat tagállam létrehozhat független szakértőkből álló ad hoc missziót abból a célból, hogy vagy saját területén, vagy valamely másik tagállam területén egy emberi jogokkal kapcsolatos problémás helyzetet oldjon meg. Rendkívüli helyzetek esetén alkalmazható a berlini mechanizmus, amelyet a kilencvenes évek elején szétbomló Jugoszlávia esetében is alkalmaztak. (Blockmans [2007] p. 40.)

$177 \mathrm{Az}$ EBESZ a daytoni rendezés értelmében részt vett a válságot követő bizalomépítési és fegyverellenőrzési folyamatban, valamint az emberi jogok érvényre juttatásában, (Recchia [2007] p. 17.) $\mathrm{s}$ tevékenyen részt vett a civil társadalom kiépítésében is. Az EBESZ mandátumáról és feladatairól ld. részletesebben a jelen fejezet végét.
} 
A daytoni megállapodás 3. számú melléklete szól a választásokról, ennek felelősévé a dokumentum aláŕrói tehát az Európai Biztonsági és Együttmüködési Szervezetet (EBESZ) tették. A választások előkészítéséért és lebonyolításáért felelős szervként létrehozták az Ideiglenes Választási Bizottságot (Privremena izborna komisija - PIK), s meghatározták, hogy ki jogosult választani: főszabályként az a 18. életévét betöltött személy, aki az 1991-es népszámláláskor boszniai állampolgár volt és nyilvántartásba vették. (Daytoni megállapodás [1995] 3. sz. melléklet, III-IV. cikk) A Választási Bizottságban az EBESZ misszióvezetője elnökölt, s egyet nem értés esetén az ő szava döntött, ráadásul - szintén a felek közti vita esetén - jogában állt rendeleteket elfogadni a politikai pártok regisztrációjával, a jelöltek és választók alkalmasságával, a választási megfigyelők feladataival, és a kampány során alkalmazandó szabályokkal kapcsolatban. (Šelo Šabić [2005] pp. 152-153.)

A választásokra a dokumentum rendelkezéseinek értelmében a hatályba lépéstől számított hat hónap múlva, de nem később, mint kilenc hónap múlva kellett sort keríteni. (Daytoni megállapodás [1995] 3. sz. melléklet, II. cikk) A boszniai választási rendszer kidolgozása az EBESZ feladata volt, amely végül - az ebben a komplex környezetben minden érintett felet kielégíteni kívánó - arányos választási modellt választotta. A választott modell minden valószínüség szerint a legbonyolultabbak között van, arra azonban alkalmas, hogy fragmentáltabbá tegye a pártrendszert - a kisebb pártoknak is parlamenti helyet biztosítva -, s ez a máig is zömmel etnikai alapon szerveződő, s a legnagyobb nacionalista pártok nyomasztó fölényével jellemezhető pártstruktúrában fontos szempont. Sajnos a formulának azon előnyét, hogy a pártrendszer változását elősegíti (megkönnyíti a régi pártok meggyengülését, az új pártok megerősödését, s így a politikai szcéna felfrissülését), Boszniában nem sikerült kiaknázni, a nacionalista tematika - a kisebb változások ellenére - megingathatatlannak tünik. A modell egyik legjelentősebb hátránya - vagyis hogy koalíciós kormányzásra ösztönöz, s nem eredményez szinte soha erős kormánytöbbséget, ami a bizonytalanságot állandósítja - viszont érezteti negatív hatásait, hiszen Boszniában a kormányalakítás egyre nehezebb feladat, legutóbb 15 hónapig nem volt a 2010-es választás után kormánya az országnak. (Berta [2001] p. 19.) Természetesen emiatt nem a választási rendszert kell okolnunk, az csupán az eszközt teremtette meg, a politikai szereplők pedig éltek vele. 
A választás bonyolultsága több tényezőre vezethető vissza: fontos megemlíteni, hogy a választási rendszer kimunkálása ugyanabban az etnikai paritást preferáló, s a háborúból éppen kilábaló környezetben született, mint a daytoni megállapodás. Kidolgozásakor igyekeztek figyelemmel lenni a háború utáni sajátos viszonyokra, s a nagyszámú menekült számára is minél szélesebb körben biztosítani a részvételt. A szabályozás azoknak is lehetővé teszi a korábbi (1991-es) lakhelyük szerinti szavazást, akik a háború után nem térhettek vissza régi otthonukba. ${ }^{178} \mathrm{Az}$ etnikai tisztogatás eredményeként sok településen teljesen kicserélődött a lakosság a háború végére az 1991-eshez állapotokhoz képest, el lehet képzelni, hogy egy adott etnikum által többségében (és általában szinte tisztán általuk) lakott településen milyen problémákat okozott, ha kellően nagyszámú korábbi - más etnikumhoz tartozó, s a háború alatt elüzött - lakos a szavazáskor erre a korábbi lakhelyére regisztrált. Ad absurdum az is megeshetett, hogy a helyi önkormányzatban a képviselői helyek számottevő része jutott az elüzött etnikum tagjainak, akiknek pedig a háború után közvetlenül még látogatóba sem volt tanácsos ellátogatni korábbi lakhelyükre.

Az EBESZ a választási törvény kidolgozásán túl lebonyolította a választási regisztrációt is, ami nehéz feladat volt, hiszen 1996-ban, amikor az első választásokat tartották, több tízezer emberről nem tudták, hogy pontosan hol van: valamelyik szomszédos vagy európai államban tartózkodik menekültként, vagy belső menekültként (internally displaced persons - IDPs) Boszniában él valahol másutt, esetleg testét valamelyik még fel nem tárt tömegsír rejti. Nemcsak ezért volt bonyolult a regisztrációs folyamat, hanem a választási szabályozás komplexitása miatt is, s azért is, mert a választásra jogosultak egy része nem rendelkezett személyi okmányokkal (mivel a háborúban azok sok esetben megsemmisültek vagy elvesztek). Az EBESZ domináns szerepvállalása természetesen nem zárta ki, hogy a helyiek üljenek a különböző szintű választási bizottságokban és előkészítő grémiumokban, a tényleges irányító szerep valójában azonban az EBESZ-é volt ezeken a helyeken is.

\footnotetext{
178 A háború lezárását követő egy-két évben (1996-1997-ben) persze azok közül, aki korábbi lakhelyük listáira adták le szavazatukat, nem feltétlenül jelentek meg személyesen a választás napján, ennek ugyanis ebben az időszakban még komoly biztonsági kockázatai lehettek azokon a helyeken, ahol a lakosság etnikai aránya a háború alatt megváltozott. Ezeknek a személyeknek lehetőségük volt új otthonukban, de a régi lakhelyük listájára szavazni (absentee voting). Azok is szavazhattak, akik nem Bosznia területén éltek a voksolás időpontjában, hanem valamely más országban (out of country voting).
} 
A daytoni mandátum alapján az EBESZ feladata a választások felügyelete (supervising) volt, de az első években a szervezet - a nemzetközi polgári igazgatás vezetőivel egyetértésben - meglehetősen tágan értelmezte ezt a jogosítványt, ${ }^{179} \mathrm{~s}$ a választások megszervezése és levezénylése sokkal inkább volt az EBESZ feladata és felelőssége, mint a helyi szerveké. A szervezet a közigazgatás minden szintjén (a legkisebb szavazókörben is $)^{180}$ mindenütt jelen volt legalább egy alkalmazottjával, aki a választás napján a választóköri történések irányításában legalább akkora szerepet játszott, mint az adott szavazókör választási bizottságának elnöke. Az első, 1996. szeptemberi voksoláson minden felszerelést ${ }^{181}$ az EBESZ biztosított, s a választások teljeskörü lebonyolítását magára vállalta. Támaszkodhatott itt kétségtelen szakértelmére és módszertanára, amely a demokratikus választások minden szakaszára és aspektusára kiterjed: a jogi szabályozási kerettől a választási adminisztráción és a kampányon keresztül egészen a szavazás megszervezéséig, a szavazatok számlálásáig és az eredmények összesítéséig, valamint kihirdetéséig, beleértve a panaszok kivizsgálását is.

A választások lebonyolítása sem volt könnyü: egyrészt számolni lehetett (és kellett is) az etnikailag kevert vagy a háború alatt jelentősen megváltozott összetételü részeken incidensekre, összetűzésekre, másrészt tartani lehetett a választási visszaélési kísérletektől is, harmadrészt pedig szokatlan és idegen volt a boszniai emberek egy jelentős része számára az a mód, ahogyan ezt a nyugati sztenderdek alapján történő választást lebonyolították. ${ }^{182} \mathrm{Az}$ EBESZ széleskörü szerepvállalása a választásokon a 2000-es választási reformokig egyre csökkent, azután a szervezet - hasonlóan más kormányközi és nem-kormányzati nemzetközi intézményhez - már megfigyelőként

\footnotetext{
179 A választási reformokig tartott választások: parlamenti és elnökválasztások (általános választások): 1996, 1998, 2002, 2006, 2010; helyhatósági választások: 1997, 2004, 2008; RS nemzetgyülési választások: 1997. (EBESZ [é. n./a])

$180 \mathrm{Az}$ EBESZ-misszió központja Szarajevóban volt, regionális központjai pedig Banja Lukában, Mostarban, Szarajevóban és Tuzlában, helyi központjai (field office) pedig 24 településen, kiegészülve az ún. Brčko-csoporttal. (Šelo Šabić [2005] p. 178.)

181 A választási paravánoktól az irányító plakátokon át a tollig, amivel a választók kitöltötték a szavazólapokat.

${ }^{182}$ Itt elsősorban arra gondolhatunk, hogy milyen problémákat okoztak az eltérő kulturális minták: pl. mennyire idegenkedve reagáltak főként az idős emberek arra, hogy - az ismételt szavazást megakadályozandó - még a választás előtt egy olyan „lemoshatatlan” folyadékkal fújták le jobb kezük egyik ujján a körömágyat, amely UV fényben világított. Az erős nemzetközi felügyelet és a rengeteg megfigyelö jelenléte miatt a szabályokat igyekeztek maximálisan betartatni a szavazókörökben. A helyiek (föként vidéken) nehezen fogadták el, hogy miért tiltják hirtelen az általuk korábban megszokott ún. családi szavazást (amikor pl. a feleség a férjjel együtt megy a szavazófülkébe).

A boszniai választási rendszer rendkívül komplex (sokak szerint az egyik legbonyolultabba a világon), s maguk az állampolgárok is többször panaszkodtak az első években, hogy nem értik a szabályozás egyes elemeit. (Bieber [2006] p. 47.)
} 
(observing) vett részt a voksolásokon. A demokráciaépítésben természetesen továbbra is aktív szerepet vállal a szervezet, de már inkább tanácsadó-monitorozó szerepkörben: ellenőrzi a választási szabályok betartását, a különböző szintű választási bizottságok müködését, jogi, technikai és politikai támogatást nyújt az egyes önkormányzatok választási testületeinek, és támogatja a 2001 nyarán felálló, független boszniai (szövetségi szinten müködő) Központi Választási Bizottságot (Centralna izborna komisija Bosne i Hercegovine). (Bosznia-Hercegovina Központi Választási Bizottsága [é. n.]) A választásokat 200 óta a helyi szervek készítik elö, bonyolítják, valamint finanszírozzák.

Az EBESZ boszniai misszióját rendre amerikai diplomata vezeti, ez a hallgatólagos megállapodás garantálta, hogy a polgári igazgatás egyik fontos pozícióját megkapják az amerikaiak. S bár az EBESZ nevében szerepel az európai jelző, meglehetősen nyilvánvaló, hogy a szervezet tényleges irányítója az Amerikai Egyesült Államok. A háború utáni rendezés során egyértelmüvé vált, hogy az az európai szervezet, amely versenytársa lehetett volna Boszniában több területen is az EBESZ-nek, amerikai nyomásra kiszorult a nemzetközi igazgatásból. Ez a szervezet az Európa Tanács volt.

A dolgozatban ugyan a nemzetközi szerepvállalásra fókuszálunk, itt azonban érdemes kitérni néhány gondolat erejéig a boszniai választásokra. Nem az a célunk, hogy az egyes választások eredményeit részletesen ismertessük, hanem hogy a nemzetközi igazgatás szempontjából fontos tanulságokat levonjuk. Az első általános választásnak 1996 decemberében kiemelkedő jelentősége volt; a nemzetközi közösség úgy vélte, minél előbb meg kell ezt szervezni, hogy a boszniai társadalom demokratikusan megválasztott vezetőinek át lehessen adni a hatalmat. A választások gyors lebonyolítása mögött azonban valójában a daytoni rendezésböl kiolvasható szándék állt, vagyis az, hogy minél előbb ki lehessen vonni a nemzetközi igazgatás erőit. ${ }^{183}$ Elsősorban az amerikaiak gyakoroltak nyomást és terelték ebbe az irányba a rendezési folyamatot, mert Bill Clinton az 1996-os választási kampány öszi finisében Boszniát már külpolitikai sikerként szerette volna felmutatni. A politikai okok mellett téves várakozások is meghúzódtak a háttérben: az egyik feltételezés az volt, hogy a boszniai választópolgárok a háborúban főszerepet játszó nacionalista erőket a haladást gátló

\footnotetext{
${ }^{183}$ A daytoni megállapodásban erre utalt az a tény is, hogy az IFOR mandátumát eredetileg csupán egy évre tervezték.
} 
tényezőnek tekintik ekkorra már, és nem szavaznak majd rájuk a választásokon. Szintén hibásnak bizonyult az a várakozás, hogy a boszniai politikai vezetők - akik a választások nyomán újra kezükbe kapják a saját sorsuk irányításához szükséges jogokat - a nemzetközi igazgatási struktúra felszámolása után belátják az együttmüködés szükségességét és megértik, hogy politikai felelősségük is ezt diktálja. (Caplan [2005] p. 121.) Sajnos az idő bebizonyította, hogy utóbbi gondolat máig sem eresztett mély gyökereket a boszniai politikai vezetők jelentős részének gondolkodásában, s az is bizonyos, hogy az 1996-os kudarc oka a választás megtartásának sürgetése volt. Nem várt hatással járt ugyanis a nemzetközi közösség kivonulási szándékának nyilvánvalóvá válása a boszniai lakosság körében: a választásokon éppen azokra szavaztak, akik érdekeiket a leginkább képviselték a háború alatt, a nacionalista a politikai erőkre. ${ }^{184}$ (Caplan [2005] p. 121.) Más ugyanis nem nagyon volt a láthatáron: a háború lezárása óta eltelt nem egészen egy éves időszakban nem tudott kiemelkedni és megerösödni olyan, nem etnikai-nacionalista alapon szerveződő politikai erő, amely hitelesen tudta volna képviselni a haladás helyes irányát. A rosszul időzített (túl korai) választás során a háború közelsége miatt ugyanazon erők léptek müködésbe a választók mobilizálása során ugyanazon témák mentén, mint amelyek a háború alatt is összekovácsolták az egyes etnikumok tagjait. Az eredmény az lett, hogy a háború „folytatódott” a politikai színtéren, csak a korábbi „hadvezérek” tisztségviselővé lettek a választás következtében. (Chesterman [2004. p. 207.]) A demokratikus hatalomátadás eredménye tehát az lett, hogy azok a személyek lettek a legitimitás hordozói, akik közül nem egy nyíltan ellenezte a daytoni megoldást és a másik etnikum tagjaival való egy államban létezést kényszerként élte meg, sőt akadtak köztük, akikre később rábizonyították, hogy háborús bünöket követtek el a délszláv válság idején. ${ }^{185}$ A rossz időzítés mellett valószínűleg szerencsésebb lett volna nem az általános választásokkal kezdeni, hanem a helyhatóságival, mert utóbbi nem jár akkora politikai kockázattal, sokkal kevésbé lehet

\footnotetext{
${ }^{184}$ A legerősebb etnikai-nacionalista pártok Boszniában: a bosnyák Demokratikus Akciópárt (Stranka demokratske akcije - SDA), a boszniai szerb Szerb Demokrata Párt (Српска демократска странка SDS) és a boszniai horvát Demokratikus Közösség (Hrvatska demokratska zajednica Bosne $i$ Hercegovine - HDZ $\mathrm{BiH})$.

${ }^{185}$ A helyzetet jól szemlélteti Richard Holbrooke amerikai diplomata reagálása is az 1996-os szeptemberi választások eredményeire. A politikusról érdemes tudni, hogy Clinton-adminisztráció egyik legfőbb Balkán-tanácsadója és diplomatája volt. Holbrooke a következőket mondta: „Gondolom, a választásokat szabadnak és tisztességesnek nyilvánították”, a megválasztottak pedig „rasszisták, fasiszták, szeparatisták, akik nyíltan ellenzik a [békét és az újraegyesülést]: Ez ám a dilemma.”. Az idézetet Fareed Zakaria közölte az illiberális demokráciáról írott cikke első mondatában. (Zakaria [1997] p. 23.)
} 
ugyanis a politikai közbeszéd részévé tenni a nagypolitikára jellemző, s a társadalmi megosztottságot elmélyítő témákat. (Chesterman [2004] p. 210.)

A nemzetközi közösség igyekezett levonni a következetéseket az első választás kudarcaiból, a következő általános választást többször elhalasztották, s beindult az ún. political engineering (amit talán „,választási mesterkedés”-nek vagy „trükközés”-nek lehetne fordítani). Ennek során a nemzetközi közösség elkezdett „kampányolni” a demokratikus és nem etnikai alapon szerveződő politikai pártok mellett 1998-ban és 2002-ben, lényegében arra szólítva fel a lakosságot, hogy rájuk szavazzanak, később pedig a választási szabályokat igyekeztek úgy módosítani a Föderáció felsőházi választásán, hogy a mérsékelt, nem etnikai alapon szerveződő erőket hozzák kedvezőbb helyzetbe. Ezek a próbálkozás azonban nem hoztak számottevő eredményt (elsősorban a rossz időzítés miatt), sőt bizonyos morális aggályokat is felvetettek. (Caplan [2005] p. 128.)

A későbbi választások közül a 2000-es választásokat érdemes kiemelni, mivel itt történt meg első alkalommal, hogy a hagyományos, etnikai-nacionalista alapon szerveződő pártok némiképp háttérbe szorultak. A 2000. áprilisi helyhatósági választásokon elmozdulást a bosnyák és a szerb pártok körében láthattunk, a bosnyák pártok esetében a lényeg, hogy ekkor első alkalommal a háború idején is vezető bosnyák politikai erőként müködő, és sokáig megszoríthatatlannak tünő Demokratikus Akciópárt (SDA) alulmaradt egy nevében ugyan szociáldemokrata, de valójában elsősorban bosnyák párttal, a Bosznia-hercegovinai Szociáldemokrata Párttal (Socijaldemokratska Partija Bosne i Hercegovine - SDP) szemben. Az SDP azonban csak a bosnyák többségü önkormányzatokban került relatív vagy abszolút többségbe, igazi áttörésről tehát nem beszélhettünk. Ugyanezen a választáson a szerb pártok közül a legtöbb voksot a Szerb Demokrata Párt (SDS) ${ }^{186}$ kapta, s így maga mögé utasította az akkor leginkább radikálisnak tekinthető boszniai Szerb Radikális Pártot (Српска радикална странка ) Srpska radikalna stranka - SRS). Sajnos ezt sem tekinthetjük valódi mérföldkőnek, mert erre az eredményre lehetett számítani, miután az Ideiglenes Választási Bizottság -

\footnotetext{
${ }^{186}$ Az SDS volt a háború alatt a legerősebb szerb párt Boszniában, a 2000-es választáson a „visszatérése” történt meg. A párt időközben szakított Radovan Karadžićcsal, s 2000-ben mérsékeltebb hangvétellel tért vissza, ám az International Crisis Group szerint „kutyából nem lesz szalonna” (az eredeti, angol nyelvü szövegben: "the leopard hasn't changed its spots"). (ICG [2000/a] p. 14.)
} 
addig példátlan döntéssel - az SRS számos induló jelöltjét kizárta a választásokból. ${ }^{187}$ (ICG [2000/a] pp. 10-14.)

Szintén ezen a 2000 tavaszi választáson alkalmaztak elsőként néhány olyan intézményt, amelyet a demokratizálódás útján való előrehaladásként értékelhetünk: egyrészt életbe léptek a kampányfinanszírozásra vonatkozó korlátozások, másrészt pedig itt alkalmazták elsőként a nők részvételére vonatkozó kötelező kvótát (a pártlistákon a helyek legalább 1/3-át a nőknek kellett juttatni). (Belloni [2007] p. 80.)

A 2000 novemberében tartott általános választások sajnos igazolták a félelmeket: sem az áprilisi helyhatósági választásokon tapasztalt politikai átrendeződés nem bizonyult tartósnak, sem pedig a Horvátországban és Szerbiában lezajlott demokratikus változások nem hatottak jótékonyan a boszniai politikai életre - sőt, a boszniai nacionalista erők újabb megerősödésének lehettünk tanúi ezen a választáson. (ICG $[2000 / \mathrm{b}])$

Az EBESZ müködésének első öt évében a választásokra koncentrált, annak a nemzetközi közösség körében a daytoni rendezés során teret nyert meggyőződésnek megfelelően, miszerint a sikeres választások lesznek az ún. exit strategy alapvető pillérei: vagyis ha a haladó erők irányítják majd az országot, akkor a nemzetközi erők is elhagyhatják Boszniát. A második, 1997-es választást követően világos volt, hogy erre nem lehet számítani, s valóban nem történt érdemi változás, a nacionalista eröket nem lehet visszaszorítani. Az egyik főmegbízott, Paddy Ashdown ezen később így sajnálkozott:

„azt hittük, hogy a demokráciának kell az elsődleges prioritást biztosítanunk, s azt hittük, ennek az a módja, hogy minél több választást megszervezünk. Hét évvel később azt értük el, hogy a boszniai emberek belefáradtak a voksolásba. Ráadásul a választásokra való fókuszálás miatt kevesebb erőfeszítést tettünk a szervezett bünözés és a korrupció visszaszorítására, ami pedig aláásta az itteniek életminőségét és elijesztette a külföldi befektetőket." (idézi Chesterman [2004] p. 207.)

\footnotetext{
${ }^{187}$ A kizárás oka az volt, hogy a választási szabályok szerint nem indulhat a választásokon az, aki gazdasági társaságok igazgatóságában tag, vagy olyan lakásban / házban lakik, ami egy menekült vagy belső menekült tulajdonában áll. (ICG [2000/a] p. 6.)
} 
Az EBESZ tevékenységében 2001, az új választási törvény elfogadása jelentette a váltást, amennyiben a továbbiakban a helyi erők vették át a választások megszervezésének felelősségét, a szervezet pedig nagyobb erőkkel fókuszálhatott egyéb feladataira, elsősorban a demokratizálódás folyamatának előmozdítására. Az EBESZ „háromdimenziós” struktúrája jelöli ki a szervezet fő feladatait, ezek: 1) politikai és katonai, 2) gazdasági és környezeti és 3) humanitárius és a biztonság humán dimenzióját érintő. Az EBESZ választási tevékenysége a választások fizikai lebonyolításán túl egyre több politikai és a demokratizálódást célzó tevékenységet foglalt magába, ezek: a civil társadalom és a pártrendszer fejlődésének előmozdítása; média-monitoring, a nők politikai részvételének támogatása, választói oktatás (voter education); jó kormányzás; programok a romáknak és a nemzeti kisebbségeknek; a jogállamiság fejlesztése; az oktatási reformba történő bekapcsolódás. (Davidson [2005] p. 125.) 


\section{A NEMZETKÖZI IGAZGATÁS KOSZOVÓBAN}

\subsection{Koszovó a háború lezárásakor}

Az ENSZ Biztonsági Tanácsa 4011. ülésén, 1999. június 10-én ellenszavazat nélkül (Kína tartózkodása mellett) fogadta el 1244-es határozatát ${ }^{188}$ az ENSZ Alapokmány VII. fejezetére hivatkozva. A dokumentum lezárta a polgárháborút a koszovói albánok és a szerbek között és Koszovó sorsát azóta is alapvető mértékben meghatározza, tekintve, hogy sem új BT határozat, sem egyéb nemzetközi jogi szerződés nem született azóta, amely felülírná rendelkezéseit.

Az 1244-es BT határozat - hasonlóan a daytoni megállapodáshoz - kompromisszum eredménye. A különbség az, hogy míg a daytoni megállapodás a háborúban részt vevő három balkáni etnikum és a nemzetközi közösség kompromisszuma volt, addig az 1244-es BT határozat - egy fegyveres nemzetközi beavatkozást követően - a „győztesek”, vagyis a beavatkozó és a térségben érintett nagyhatalmak közti kompromisszum. Olyan megállapodás, amely a nyugati államok (az Amerikai Egyesült Államok és a nyugat-európai államok), Oroszország és Kína érdekeit tükrözi, és mindannyiuk számára elfogadható. A válságban érintett felek, vagyis a „,vesztes” Jugoszláv Szövetségi Köztársaság (JSzK) és a koszovói albánok vajmi kevéssé érvényesíthették érdekeiket a határozat rendelkezéseinek megalkotásakor.

Az albánok alapvetően elégedettek voltak a BT határozattal, hiszen felfogásuk szerint egy hosszú konfliktus végére ha nem is tett pontot, de a Jugoszláv Szövetségi Köztársaság (JSzK) szuverenitását a terület felett „,megszüntette” (de facto legalábbis), s ily módon véget vetett a koszovói albánok elnyomásának. A szerbek akarata annyiban érvényesült a végső rendezésnél, hogy a nemzetközi igazgatás Koszovóban ENSZvezetés alatt valósult meg. A rambouillet-i tárgyalások során és azt követően, a NATObombázások idején, még az EBESZ vagy az EU irányításával vizionálták a válság

${ }^{188}$ Az1244. számú BT határozat teljes szövegét lásd az ENSZ honlapján. Security Council Resolution 1244 (S/RES/1244 [1999]) 
lezárását követő nemzetközi igazgatást, Milošević azonban a végsőkig ragaszkodott ahhoz, hogy ENSZ-adminisztráció lépjen a szerb közigazgatás helyére. A szerbek politikai vezetője valószínűleg arra számított, hogy a kilencvenes évek első felében zajló délszláv válság idején az ENSZ tevékenysége egyértelmüen kudarcnak tekinthető, s az 1995 utáni boszniai rendezési folyamat legfőbb letéteményeseként szintén nem bizonyult túlzottan hatékonynak a világszervezet. Milošević arra számított, hogy egy „gyenge” nemzetközi (ENSZ) irányítás alatt sokkal több lehetősége nyílik hatalma megszilárdítására és megtartására, mint egy hatékonyabb EBESZ- vagy EU-irányította nemzetközi adminisztráció esetén. Természetesen nem kerülhetett volna a határozat rendelkezései közé az ENSZ vezető szerepének deklarálása (pusztán a szerb vezető igényeit kielégítendő), ha nem övezi nagyhatalmi egyetértés. Helyesebb lenne ez esetben a kompromisszum szót használni, hiszen az EBESZ vezető szerepét Oroszország ellenezte, az Amerikai Egyesült Államok pedig az EU-vezette nemzetközi jelenlétet zárta ki. Az ENSZ volt az a nemzetközi szervezet, amelyet mindegyik tárgyalásban részt vevő állam hajlandó volt elfogadni.

A határozat célja, hogy felvázolja az átmeneti nemzetközi igazgatás struktúráját, a megállapodás szellemiségéből - és egyébként betüjéből is - következik, hogy az ideiglenes nemzetközi igazgatás végét Koszovó státuszának végleges rendezése jelenti majd. Meglehetősen sajátos helyzetet teremt azonban az 1244-es határozat ebben a vonatkozásban, s kijelenthetjük, hogy már megszületése pillanatában sem volt mentes bizonyos ellentmondásoktól. Arról van szó, hogy az 1244-es BT határozat kiáll a Jugoszláv Szövetségi Köztársaság szuverenitása és területi integritása mellett, ${ }^{189}$ ugyanakkor megerősíti a nemzetközi közösség határozott szándékát is a terület lényegi autonómiájának és önigazgatásának fejlesztését illetően - ez utóbbi folyamat pedig elvezethet akár a teljes önállósághoz is. (Tansey [2009] p. 113.) A koszovói válság rendezése során tehát szintén jelen vannak azok a - jugoszláv dezintegrációs folyamatot a kilencvenes évek elejétől végigkísérő - nehézségek, amelyek a nemzetközi jog kogens normáinak ütközéséből fakadnak. Az 1244-es BT határozat inherens következetlenségei még inkább paradox jelleget kölcsönöznek a ma is hatályos dokumentumnak 2008.

189 „[a Biztonsági Tanács] újból megerősíti, hogy minden tagállam elkötelezett a Jugoszláv Szövetségi Köztársaság és a régió más államainak szuverenitása és területi integritása mellett” és hogy „,a korábbi határozatokban megfogalmazottaknak megfelelően Koszovónak lényegi autonómia és tényleges önkormányzat jár”. ( S/RES/1244 [1999]) 
február 17-ét követően, amikor is Koszovó parlamentje egyoldalúan kikiáltotta függetlenségét és elszakadását Szerbiától.

\subsubsection{A nemzetközi igazgatás jogi alapja: az 1244-es számú BT határozat}

A BT határozat a nemzetközi polgári és katonai-biztonsági jelenlét alapvető struktúráját határozza meg, méghozzá alapvetően azon elvek alapján, amelyek már korábban is megjelentek a koszovói válság lezárását célzó tárgyalások, békekonferenciák során és a megállapodás-tervezetekben. A határozat két része a főszöveg és a két függelék, rendelkezéseinek alapját pedig a G8-ak külügyminisztereinek 1999. május 6-án tartott petersbergi értekezletén elfogadott rendezési elvek, és az 1999. június 2-án aláírt belgrádi katonai-technikai megállapodás pontjai adják. ${ }^{190}$ A határozat több helyen utal az ENSZ korábbi, a válság kapcsán született BT határozataira, ${ }^{191}$ az ENSZ fötitkárának korábbi állásfoglalására ${ }^{192}$ és a rambouillet-i megállapodásra ${ }^{193}$ is. A dokumentum a következő rendelkezéseket tartalmazza:

- a JSzK azonnali hatállyal vessen véget az erőszaknak és az elnyomásnak Koszovóban, és vonja vissza katonai, rendőri és félkatonai egységeit a tartomány területéről;

- jugoszláv és szerb katonai és rendőri erők a kivonás után csak bizonyos speciális feladatok végrehajtásának céljából maradhatnak Koszovóban, ezek: kapcsolattartás a nemzetközi polgári igazgatással és a nemzetközi biztonsági erőkkel, aknajelölés és -mentesítés, jelenlét a szerb emlékhelyeknél, valamint a kulcsfontosságú határátkelőhelyeknél,

- az ENSZ felügyelete alatt a tartomány igazgatásáért nemzetközi polgári és katonai jelenlét lesz felelős; kezdetben 12 hónapos mandátummal, amelyet a BT döntése megújíthat.

\footnotetext{
${ }^{190}$ A petersbergi elvek az 1244-es BT határozat 1. függelékét képezik (az ENSZ saját nyilvántartásában a dokumentum hivatkozási száma: S/1999/516). A belgrádi megállapodás (S/1999/649) kilenc pontja az 1244-es határozat 2. számú függelékében található.

191 A hivatkozott korábbi BT határozatok a következők: 1160 (1998. március 31.), 1199 (1998. szeptember 23.), 1203 (1998. október 24.) és 1239 (1999, május 14.).

192 1999. április 8-án Kofi Annan arra hívta fel a nemzetközi közösség figyelmét, hogy Koszovóban humanitárius katasztrófa zajlik.

${ }^{193}$ A rambouillet-i megállapodás (Rambouillet Accords - Interim Agreement for Peace and SelfGovernment in Kosovo of 23 February 1999) A dokumentum - amelyet végül a szerbek elutasítottak rendelkezett volna Koszovó széleskörủ autonómiájáról és önkormányzatiságáról, de nem vágta volna el a Szerb Köztársasághoz füződő kötelékeit. A JSzK-t alkotó két állammal egyenlő jogai lettek volna Koszovónak, bár formailag Szerbia része lett (maradt) volna. (Stahn [2001] p. 117.)
} 
- a nemzetközi polgári igazgatás élére az ENSZ fötitkára különleges megbízottat nevez ki, akinek feladata lesz a nemzetközi biztonsági erőkkel történő együttmüködés is a kitüzött céloknak megfelelően;

- a tagállamokat és a releváns nemzetközi szervezeteket a Biztonsági Tanács felhatalmazza, hogy nemzetközi biztonsági erőket állítsanak fel és telepítsenek Koszovóba az alábbi feladatok ellátására: az ellenségeskedések kiújulásának megakadályozása; a jugoszláv erők kivonulásának felügyelete; a UÇK és más fegyveres albán csoportok leszerelésének ellenőrzése; biztonságos környezet megteremtése a menekültek visszatéréséhez, a nemzetközi civil igazgatás müködéséhez és a humanitárius segélyek szállításához; a közrend és a közbiztonság biztosítása és az aknaszedés felügyelete, amíg ezeket a feladatokat a nemzetközi civil igazgatás át nem veszi; szükséges mértékben határellenőrzési feladatok; a nemzetközi igazgatás és a nemzetközi szervezetek képviselőinek védelem és a szabad helyváltoztatás jogának biztosítása.

- A BT felhatalmazza a fótitkárt és a releváns nemzetközi szervezeteket, hogy a közigazgatás működtetésének feladatát ideiglenesen ellássák. A nemzetközi adminisztráció átmeneti jellegü, addig müködik, amíg feladatait a kiépülő demokratikus intézményrendszer át nem tudja venni. A nemzetközi polgári igazgatás feladatai a következők: a lényegi autonómia és az önkormányzatiság intézményei kiépülésének felügyelete; a közigazgatás funkcióinak ellátása ideiglenes intézményeken keresztül, ameddig ezt a funkciót a helyi szervek át nem tudják venni és ameddig szükséges; a választások megszervezése és felügyelete; a Koszovó jövőbeli státuszának meghatározására irányuló politikai folyamat előmozdítása; a demokratikus intézményrendszer kiépülését követően az ideiglenes intézményei hatósági jogosítványainak átadása a helyi szervek számára; a kulcságazatok újjáépítésének és a gazdasági segélyezésnek a támogatása, együttmüködve a nemzetközi humanitárius szervezetekkel és segélyszervezetekkel; a közrend és közbiztonság fenntartása a nemzetközi rendőri erők segítségével és a helyi rendőrség kiépítése mellett; az emberi jogok védelmének előmozdítása; a menekültek visszatérésének biztosítása.

- A határozat értelmében a JSzK köteles együttmüködni a nemzetközi közösség helyszínen tevékenykedő képviselőivel és a hágai törvényszékkel és biztosítani a humanitárius és segélyszállítmányok zavartalan célba juttatását. 
- A nemzetközi közösséget arra szólítja fel a határozatban a BT, hogy járuljanak hozzá Koszovó gazdasági és társadalmi rekonstrukciójához, s e célból szervezzenek ún. donorkonferenciákat. A gazdaságfejlesztésről szólva a határozat külön is említi az Európai Uniót és a Délkelet-európai Stabilitási Paktum ${ }^{194}$ elnevezésü kezdeményezést.

- A BT a főtitkárt bízta meg, hogy rendszeres időközönként jelentésben számoljon be a határozat rendelkezéseinek betartásáról és az elért eredményekről. (S/RES/1244 [1999])

A nemzetközi polgári igazgatás alapvető keretét a négypilléres UNMIK (United Nations Interim Administration Mission in Kosovo) adta egészen 2008-ig, amikortól az Európai Unió jogi és igazgatási missziója (European Union Rule of Law Mission - EULEX) vette át a helyét. A dolgozat behatóan az 1999 és 2008 közötti struktúrát vizsgálja, amelynek két alappillére az UNMIK és a KFOR. A 2008 utáni fejleményekkel és az EULEX-szel csupán érintőlegesen és jóval kisebb terjedelemben foglalkozik.

\subsection{Nemzetközi igazgatás Koszovóban 1999 és 2008 között}

Az UNMIK keretében megvalósuló nemzetközi igazgatás az ENSZ történetében rendkívüli vállalkozásnak számít, hiszen a szervezet ideiglenes jelleggel a teljes közigazgatás müködtetését magára vállalta Koszovó esetében. Azt is kijelenthetjük ugyanakkor, hogy az ENSZ ezen vállalása jóval túlmutat a békefenntartás első és második generációjának feladatkörein.

194 A koszovói válságnak véget vető NATO-bombázások befejezésekor az Európai Unió kezdeményezéseként merült fel, de végül szélesebb körü nemzetközi együttmüködésként jött létre 1999. május 17-én a Délkelet-európai Stabilitási Egyezmény (vagy Paktum). A kezdeményezésben több mint 40 nemzetközi szervezet, regionális kezdeményezés és állam vett részt, a végeredmény pedig a nemzetközi együttmüködés sajátos, fórumjellegü intézménye lett. Legfőbb célokként régió stabilizálását és transzformálását jelölik meg (Stability Pact for South Eastern Europe [1999]), és kiemelt helyen szerepel a nyugat-balkáni országok közti együttmúködés, valamint a békés, jószomszédi kapcsolatok előmozdítása. A regionális kooperáció mellett a Stabilitási Paktum másik sarokpontja az európai integráció előmozdítása. A Paktumot útjára bocsátó tanácsi közös álláspont első alkalommal tartalmaz egyértelmü utalást arra, hogy az Európai Unió - az amszterdami szerződésben foglaltak és a koppenhágai kritériumok teljesítése esetén - nyitott a nyugat-balkáni államok teljes jogú tagként történő befogadására. (Kemenszky [2008]) 
Az 1244-es BT határozat alapján az UNMIK feladata a következőkből áll:

- az érdemi autonómia és önkormányzatiság létrehozásának támogatása;

- az alapvető polgári igazgatási funkciók ellátása;

- a demokratikus és autonóm önkormányzás átmeneti intézményei kialakításának felügyelete;

- a választások lebonyolítása;

- a Koszovó végső státuszáról szóló politikai párbeszéd előmozdítása, e folyamat végső szakaszában pedig a hatáskörök átadása a helyi szerveknek;

- gazdasági és infrastrukturális újjáépítés;

- humanitárius segélyezés;

- a közrend fenntartása, a nemzetközi és a létrehozandó helyi rendőri erők bevonásával;

- az emberi jogok érvényesülésének elömozdítása;

- a menekültek visszatérésének elősegítése. (S/RES/1244 [1999] 11. cikk)

Az 1244-es BT határozat rendelkezései nem szabályozzák részletekbe menően a nemzetközi igazgatással kapcsolatos kérdéseket. Nem rendelkezik a dokumentum a nemzetközi igazgatás pontos struktúrájáról és az abban részt vevő egyes nemzetközi aktorok szerepéről, ${ }^{195} \mathrm{~s}$ nem szabályozza a nemzetközi és a helyi szervek közti hatalommegosztást sem. Csupán az ENSZ főtitkár második jelentésében (1999. júliusban) ${ }^{196}$ kezd körvonalazódni az igazgatás struktúrája és feladatai, s Kofi Annan jelentésében megállapítja, hogy az UNMIK Koszovóban a legfőbb végrehajtó és törvényhozó hatalom birtokosa lesz, és teljes mértékben átveszi a tartomány igazgatását. (Zaum [2007] p. 132.) A feladatmeghatározás és a mandátum tekintetében még ennél is részletesebb azonban az 1999. július 25-én kiadott 1999/1-es számú UNMIK-rendelet, ${ }^{197}$ amit szokás „,minden rendeletek anyjának” is nevezni. (Yannis [2006] p. 69.)

\footnotetext{
${ }^{195}$ Ezt majd az 1272-es BT határozat teszi meg 1999 októberében.

196 Report of the Secretary-General on the United Nations Interim Mission in Kosovo (S/1999/779 [1999])

${ }_{197}$ UNMIK Regulation 1999/1, On the Authority of the Interim Administration in Kosovo (UNMIK/REG/1999/1 [1999])
} 


\subsubsection{Az UNMIK eredeti pilléres szerkezete és az SRSG}

A két említett dokumentum felvázolja az UNMIK négypilléres struktúráját is, amelynek élén a koszovói különmegbízott (SRSG - Special Representative of the Secretary General) áll. Az SRSG a legföbb törvényhozó és végrehajtó hatalom birtokosa, munkáját politikai, jogi, gazdasági és emberi jogi szakértőkből álló csapat (kabinet) segíti. A civil igazgatás feje a polgári végrehajtó jogosítványok rendkívül széles spektrumának birtokosa, s az 1244-es BT határozat értelmében szükség esetén jogosítványainak kiterjesztéséről is dönthet. Az SRSG-nek hatalmában áll hatályos jogszabályokat megváltoztatni, visszahívni, vagy akár alkalmazásukat felfüggeszteni, tisztségviselőket szabadon kinevezni vagy éppen elmozdítani hivatalából. (Tansey [2009] p. 114.) Az SRSG rendeleteket bocsát ki, ezek az ideiglenes nemzetközi adminisztráció által alkotott jogszabályok, minden egyes rendeletet véleményez egyfelől az SRSG kabinetjének jogi tanácsadója, másfelöl pedig az ENSZ Jogi Tanácsadó Irodája (Office of the Legal Adviser - OLA). Ha ezeken a szürökön átmegy a rendelet és nem merül fel ellene kifogás, akkor az SRSG aláírja. Az SRSG-nek minden pillér élén áll egy-egy helyettese, s rajtuk kívül van még egy legfőbb helyettese is, akinek felelősségi területe általános és nem korlátozódik egy pillérre.

1999-ben a négypilléres struktúrát úgy igyekeztek kialakítani, hogy egyfelől azokat a területeket különítsék el, amelyek a legjelentősebb megoldandó problémákat jelentik Koszovóban, másfelől pedig az egységes szerkezettel biztosítsák a nemzetközi közösség összehangolt munkáját. Ez utóbbi cél a boszniai struktúra egyik legjelentősebb hibáját igyekezett kiküszöbölni, ott ugyanis nem létezik egy, a koszovói UNMIK-hoz hasonló „ernyőszervezet”, amely keretet biztosít a nemzetközi civil adminisztráció számára. A pillérek közül az első a humanitárius ügyek összefogásáért és koordinálásáért volt felelős az ENSZ Menekültügyi Föbiztosságának (UNHCR) vezetésével. A második pillér a közigazgatási feladatokat látta el, de az első években ide tartozott a rendőrség és az igazságszolgáltatás is, ennek a pillérnek a munkáját az ENSZ látta el. A harmadik pillér feladata az EBESZ vezetésével a demokratizálódás és intézményépités volt, a negyedik pedig az EU irányitása alatt a gazdasági fejlesztés és segélyezés koordinálását látta el. (Zaum [2007] p. 134.) A pillérek önállósága meglehetősen kiterjedt volt: mindegyikre az volt a jellemzö, hogy az a bürokratikus és szervezeti kultúra honosodott 
meg egy-egy pillérben, amelyik arra a nemzetközi szervezetre jellemző, amely az adott pillér müködtetéséért felelös.

A nemzetközi igazgatás fentiekben vázolt müködése két kérdést vet fel rögtön, az egyik a pillérek közötti együttmúködés hatékonysága, a másik pedig a helyi szervek bevonásának mértéke. Azért fontos, hogy ezeket a kérdéseket megvizsgáljuk, mert más tényezők vizsgálata mellett - ez a két terület lakmuszpapírként jelzi, hogy teljesülte az egyik kitüzött cél: hatékonyabb struktúrát sikerült-e Koszovóban létrehozni a boszniaihoz képest.

Ami a pillérek közti - és egyben a helyszínen tevékenykedő nemzetközi szervezetek közti - kooperációt illeti, az együttmüködés formális keretei már kezdettől fogva adottak voltak. A legfőbb koordináló szerv a Végrehajtó Bizottság (Executive Committee - EXCOM) volt, amelynek keretében naponta találkoztak az SRSG, legfőbb helyettese és a pilléreket vezető helyettesek, valamint a KFOR-t vezető föparancsnok (KFOR Commander - COMKFOR). (Zaum [2007] p. 134.)

A helyiekkel történő együttmüködés fóruma a Koszovói Átmeneti Tanács (Kosovo Transitional Council - KTC) volt, amely a helyi jelentősebb politikai erők és etnikai csoportok képviselőinek fórumaként szolgált. (Tansey [2009] p. 118.) A KTC megalapítása is jelezte, hogy a nemzetközi közösség képviselői tisztában voltak azzal, hogy az átmeneti jellegü nemzetközi igazgatástól fokozatosan a helyi erők kell, hogy átvegyék a közhatalmi jogosítványokat, ehhez pedig az önrendelkezés jogát fokozatosan és egyre növekvő mértékben biztosítani kell. Az a tény azonban, hogy a KTC csupán konzultatív szerepet kapott a tartomány igazgatásában, jelzi, hogy a nemzetközi közösség számára az elsőrendű prioritás a stabil és hatékony igazgatás, nem pedig az önrendelkezés minél előbbi átadása volt. (Zaum [2007] p. 134.)

\subsubsection{Az UNMIK-vezette nemzetközi civil igazgatás szakaszai}

A nemzetközi közösség eredeti tervei szerint az UNMIK ideiglenes igazgatása Koszovóban egy három szakaszból álló folyamatot jelentett volna, olyan folyamatot, amelyet az ésszerüség, s a kifejezetten technokrata stílus jellemzett volna. 
A tervezett első szakaszban a politikai kontrollt minden terület felett teljes egészében az UNMIK gyakorolta volna, közvetlen irányítással. Ebben a szakaszban a minden funkciót ellátó, nemzetközi vezetésű igazgatási struktúra kiépítése és müködtetése lett volna a feladat, a helyi erőknek érdemi részvételre még nem lett volna lehetősége. A második szakaszban a demokratikus választások után felálltak volna az önkormányzás ideiglenes intézményei, s ebben a szakaszban a nemzetközi vezetés mindenütt fokozatosan átadta volna hatalmi jogosítványait a helyi szereplőknek. A harmadik szakaszban fejeződött volna be és teljesedett volna ki a hatalomátadás folyamata, és született volna döntés a tartomány végső státuszáról is. Ennek a szakasznak a végére egy vegytisztán elméleti forgatókönyv szerint - az új hatalomgyakorlók kezébe került volna a teljes politikai hatalom, s a nemzetközi közösség nem rendelkezett volna tovább a szuverenitást csorbító jogosítványokkal, s kivonult volna a területről. (Zaum [2007] p. 134.) Az elméleti forgatókönyv - ma már tudjuk - nem éppen az imént vázoltak szerint alakult, a realitások jócskán felülírták az eredeti elképzeléseket. Nemcsak hogy kénytelen volt eltérni az UNMIK az eredeti tervétől a szakaszok ütemezését illetően, de kivonulása sem a tervek szerint történt.

Egészen 2008-ig igen változatos elképzelések, hovatovább találgatások jelentek meg az elméleti szakfolyóiratok hasábjain a lehetséges kivonulási stratégiákat és forgatókönyveket illetően. A találgatásoknak 2008. február 17. után nem volt tovább értelme, azzal, hogy a koszovói albánok kikiáltották a függetlenséget, kész helyzetet teremtettek. Az már egy ideje - talán a 2004-es tavaszi zavargások óta - azonban meglehetősen egyértelmű volt, hogy a kivonulás nem jelentheti a nemzetközi jelenlét teljes megszűnését majd Koszovóban. Ezt több tényező is indokolta. Az egyik Koszovó helyzetéből adódott, amennyiben a Szerbiával való viszonyában nem jelentett érdemi változást a demokratikusabb politikai kurzusok hatalomra jutása sem, s világossá vált: a tartomány státuszának kérdésében egyik jelentősebb politikai erő sem ragadtatja magát arra, hogy megdöntse a tabut, s lemondjon a tartományról. A szerb szomszéddal való feszült viszony elhúzódó konfliktusgóccá teszi Koszovót, nem beszélve ehelyütt a szomszédos szláv-ortodox többségü államok (Macedónia, Montenegró) albán kisebbségeiről és a feszültségek tovaterjedésének még mindig nem szünő veszélyeiről. A nemzetközi, főként biztonsági jelenlét azonban nemcsak Koszovónak a szomszédos államokkal szembeni törékeny helyzete miatt kívánatos, hanem a koszovói belső 
tényezők is indokolják - ez tehát a másik okcsoport. Itt mindenek előtt a többségi albánságnak a koszovói kisebbségekkel való viszonyát kell megemlítenünk, mint problematikus területet, elsősorban a koszovói szerbek, de más kisebbségek, így például a romák vonatkozásában. Szintén fokozza a bizonytalanságot a koszovói albánságon belül húzódó törésvonalak megléte, amely megnehezíti a stabil és hatékony hatalomgyakorlást a jelentősebb politikai erők számára (bármelyikük is van éppen hatalmon). Szintén a belső tényezők között kell említenünk azt is, hogy Koszovóban számos tényező nehezíti a stabil állami lét megszilárdulását, ilyenek: a súlyos gazdasági helyzet, a korrupció és a nemzetközi bünözés, hogy csak a legfontosabbakat emeljük ki.

Mindezen felsorolt tényezők - annak ellenére, hogy javarészüket a belső bizonytalansági faktorok között említettük - komoly biztonsági kockázatott jelentenek a szükebb és tágabb európai környezetre egyaránt. A nemzetközi közösségnek, de leginkább az Európai Uniónak elemi érdeke, hogy ezért továbbra is nemzetközi biztonsági jelenléttel garantálja a kontinens ezen térségének stabilitását és egyre inkább ellenőrző-tanácsadó jelleggel, de továbbra is nemzetközi civil erőket állomásoztasson a térségben.

A nemzetközi igazgatás bemutatása a polgári és katonai igazgatás eseményeinek leírásán túl annak értékelését is jelenti majd az alábbiakban. A szakaszhatárok megjelölésénél felhasználjuk King és Mason - két, Koszovóban az UNMIK szolgálatában álló nemzetközi tisztségviselő - munkáját, akik a koszovói nemzetközi igazgatást négy szakaszra osztották. ${ }^{198}$ Ebből a felosztásból - némileg módosítva és kiegészítve - indulunk $\mathrm{ki} \mathrm{mi}$ is a nemzetközi adminisztráció bemutatásánál. A szakaszok tehát az alábbiak:

1. szakasz: 1999. június - 2000. október

2. szakasz: 2000. október - 2002. június

3. szakasz: 2002. június - 2004. február

4. szakasz: 2004. március - 2008. február

5. szakasz: 2008. február -

198 King, Ian - Mason, Whit [2006]: Peace at Any Price. How the World Failed Kosovo. Cornell University Press, Ithaca, New York 
3.2.2.1. Első szakasz: 1999. június - 2000. október (háború utáni helyreállitás, kompetenciaproblémák)

1999. június 10-én az ENSZ Biztonsági Tanácsa meghozta 1244-es határozatát a koszovói nemzetközi igazgatás felállításáról. Az UNMIK mandátuma - ahogyan korábban ezt már kifejtettük - a tartományban a civil igazgatás teljes körủ gyakorlására, a demokratikus kormányzáshoz szükséges intézményrendszer kiépítésére és a tartomány státuszának rendezésére irányuló politikai folyamat megalapozására terjedt ki. Egy nappal a BT határozat megszületése elött, 1999. június 9-én aláírták az ún. kumanovói megállapodást a NATO-erők Koszovóba telepítéséről és arról, hogy a Jugoszláv Szövetségi Köztársaság és Szerbia tizenegy napon belül kivonja fegyveres erőit a tartomány területéről.

A nemzetközi polgári és biztonsági jelenlét gyors felállítása alapvető jelentőségü volt 1999. június 10-e, a NATO-bombázás befejezése után, hiszen - amint azt korábban már említettük - a nemzetközi közösség az összes állami funkciót ideiglenesen magára vállalta. A nemzetközi igazgatási rendszer felállítását azonban számos nehézség hátráltatta. Az okok egy része a nemzetközi közösség jelen levő képviselőinek magatartásából vagy a nemzetközi igazgatás struktúrájából fakadt, ezen okokkal ehelyütt nem foglalkozunk, a téma a dolgozatban később tárgyalásra kerül. A nemzetközi igazgatás kiépülését akadályozó tényezők másik része viszont a koszovói belső viszonyokból eredt, s következményeként az UNMIK - eredeti mandátumának ellentmondva - nem volt képes teljes politikai kontrollt gyakorolni Koszovóban.

A háborúból kilábaló tartomány számos belső problémával szembesült (romokban heverő gazdaság, nagyszámú menekült, militarizált politika közeg stb.), ezek közül az alábbiakban azokat emeljük ki, amelyek felszámolása rendkívül nagy nehézségeket okozott a nemzetközi igazgatásnak. Az egyik ilyen belső ok (vagy inkább okcsoport) volt a nemzetközi igazgatással párhuzamosan fennmaradt és müködö struktúrák megléte, valamint a társadalom több törésvonal mentén kialakuló szabdaltsága. Az első és leginkább nyilvánvaló ilyen törésvonal Koszovó többségi albán közössége és a kisebbségek, különösen a szerb népcsoport tagjai között húzódik, s egy nagymértékben szegregált politikai és társadalmi rendszert eredményez. E jelenségről bővebben néhány bekezdéssel alább (az erőszak továbbéléséről) bővebben is szólunk. 
Nem jelentett kisebb problémát a párhuzamos struktúrák megléte sem. A nemzetközi igazgatás első fél éve - egy éve alatt az egyik legnehezebb feladat az volt, hogy a tartomány igazgatását megszerezze az UNMIK az albánlakta részeken az UÇK-tól, a szerblakta területeken pedig Belgrádtól. Ami az albánokat illeti, ők ugyan alapvetően elégedettek voltak a nemzetközi hatalomátvétellel a tartományban (nekik köszönhették, hogy kikerültek a szerbek irányítása alól), de nem volt zökkenőmentes a nemzetközi igazgatás elismerése. A koszovói albán politikai elit szerette volna, ha a nemzetközi közösség elfogadja a Koszovói Köztársaság kormányát legitim kormánynak, azt a kormányt, amely még a kilencvenes évek első felében jött létre. Ennek a - sem a szerb államvezetés, sem a nemzetközi közösség által megalakulása óta nem ismert kormánynak az irányítása alatt jött létre az ún. párhuzamos állam is Koszovóban a kilencvenes évek első felében, amely a szerbek által irányított közhivatalok és közintézmények mellőzése mellett saját oktatási, egészségügyi stb. struktúrát múködtetett a koszovói albánok részére. Nagy hagyománya volt tehát már a párhuzamos struktúráknak, s amikor 1999 nyarán átvette a tartomány irányítását a nemzetközi közösség, a kezdeti hónapokban meg is tapasztalta ennek a párhuzamosságnak a hátrányait. Példaként említhetjük a nemzetközi közösségnek a bevonulása után még hosszú ideig komoly fejfájást okozó ,ppolgármestereket”, akiket a háborút követően a Koszovói Ideiglenes Kormányzat (valójában a Koszovói Felszabadítási Hadsereg) nevezett ki a huszonkilenc önkormányzat élére.

Világosan kell látnunk, hogy a NATO-bombázás 78 napja után gyökeresen megváltozott a helyzet Koszovóban: az addig üldözött koszovói albánok a nemzetközi közösség humanitárius beavatkozása következtében felszabadultak a szerbek uralma alól, s a háború alatt elmenekült albánok nagy számban kezdték meg a visszatérést a tartományba. A szerbek viszont ezzel párhuzamosan megkezdték kivándorlásukat, ${ }^{199}$ félve az albánok bosszújától. A bosszú nem is maradt el; azonban nem csupán a szerbeknek kellett tartaniuk az „elszámoltatástól”, hanem más kisebbségeknek, főként a romáknak is, ${ }^{200}$ sőt azoknak az albánoknak is, akik a Koszovói Felszabadítási Hadsereg

\footnotetext{
199 A NATO-bombázások befejezésekor becslések szerint 150-200 ezer szerb hagyta el Koszovót. (Yannis [2001] p. 40.)

200 A romákon kívül vannak más etnikai csoportok is, amelyeket az albánok árulással és a szerb elnyomókkal való kollaborálással, valamint a háború évei alatt az elmenekült albánok ingatlanainak kifosztásával vádoltak. Ezen csoportok - egyiptomiak, gorániak - bizonyos elméletek szerint valójában
} 
megítélése szerint nem képviselték megfelelően a válság idején az albánság érdekeit. ${ }^{201}$ Az UÇK a szerbek kivonulása után gyorsan megszilárdította mindenütt a hatalmát, s a nagyobb szerb enklávékon kívül mindenütt megszerezte az irányítást, s a tartományban kvázi kormányként uralta a mindennapokat: megszervezte és müködtette a közigazgatást, a maga sajátos elvei szerint gondoskodott a közbiztonságról stb. Korábban már említettük, hogy Koszovóban a kilencvenes években kiépült és viszonylagos hatékonysággal müködött a koszovói albánok körében a párhuzamos állam, hasonló történt a NATO-bombázások után is. A különbség annyi volt, hogy a nemzetközi közösség lassú bevonulása közepette nem nagyon volt olyan erő, mely az UÇK hatalmát korlátozta volna (mint ahogyan korábban a szerbek tették). Éppen ezért igen hamarosan nyilvánvalóvá vált: a biztonságot csak azoknak garantálta az UÇK, akik nem tartoztak sem valamely megvetett kisebbség, sem az áruló albánok közé; ami pedig a közvagyont (a korábbi jugoszláv állami tulajdont) illeti, a szervezet vezetői annak egy részét felosztották egymás között és birtokolták aztán magánvagyonként. (King-Mason [2006] p. 50.)

A nemzetközi közösség képviselőinek ezen körülmények között rendkívüli nehézséget okozott az irányítás átvétele, ez az önkormányzatok nagy részénél kezdetben nem is sikerült, néhol részeredménynek számított, ha a nemzetközi szakértő egyáltalán „beülhetett” az önkormányzatba. Vezető pozícióba 1999 szeptemberében csak kilenc helyen került a nemzetközi képviselő, s a kezdeti tehetetlenség és határozatlanság után 1999 októberétől sikerült csak kivenni az UNMIK-nak az önkormányzatok irányítását a helyi vezetők kezéből. (ICG [1999] pp. 2-3.)

A párhuzamos struktúrákkal azonban nemcsak az albánok esetében kellett számolni: a szerbek esetében is jelentkezett a párhuzamosság annyiban, hogy Szerbia pedig - annak ellenére, hogy elveszítette szuverenitását Koszovó felett - a koszovói szerbeket továbbra is állampolgárainak tekintette, akiknek sorsáért felelősséggel tartozik.

romák, a külön elnevezéssel attól a negatív megítéléstől igyekeznek szabadulni, amely a romákkal kapcsolatos. Mások elfogadják ezen etnikai csoportoknak a romáktól eltérő különböző eredetét és kulturális-civilizációs jellemzőit. Érdekes, hogy a koszovói háború lezárulása után, 1999-től élénkültek fel különösen ezek az etnikai csoportok, s léptek nagyot elöre különálló identitásuk megteremtésének és/vagy bizonyításának útján.

${ }^{201} \mathrm{Az}$ igen lassan települő nemzetközi erők képtelenek voltak megfékezni az erőszakot és a bosszúhadjáratokat, mintegy 50-60 ezer szerb hagyta el a tartományt közvetlenül a bombázások utáni időszakban, a halálos áldozatok száma pedig 2000 nyarára 600 és 800 közé volt tehető. (Judah [2000] p. 1-32.) 
Támogatta őket továbbra is, például folyósította a nyugdíjakat, támogatta az iskolákat, az egészségügyi és a szociális létesítményeket stb. Ez - föként azokon a területeken, ahol a szerbek nagyobb tömbökben éltek, jellemzően Észak-Koszovóban - egy idő után azt eredményezte, hogy a szerbek is kialakították a nemzetközi és helyi albán vezetéstől független igazgatási struktúráikat, s a koszovói politikai életben való részvételük is limitált maradt, amennyiben gyakran tüntető távollétükkel bojkottálták az eseményeket (pl. több alkalommal a választásokat). (Tansey [2009] p. 115.)

Szintén a belső hátráltató tényezők közé sorolható a nemzetközi adminisztrációra nehezedő egyre erőteljesebb nyomás a koszovói politikai elit részéről annak érdekében, hogy az önigazgatás minél előbb megvalósuljon a tartományban. Az UNMIK komoly dilemma elé került: ha enged ennek a nyomásnak, akkor feladja eredeti, háromszakaszos ütemtervét, s bizonyos (általa fontosnak vélt) kritériumok teljesítését feláldozza az önigazgatás mihamarabbi megvalósításának oltárán.

A nemzetközi közösség koszovói müködésének első fél éve után, éppen a fenti okok miatt, kénytelen volt tehát változtatni addigi stratégiáján. Az igazgatás hatékony működtetése, a tartomány teljes területén az irányítás megszerzése, és nem utolsósorban saját legitimációjának növelése érdekében a kezdetben tervezettnél korábban, 1999 decemberében megkezdte a koszovóiak bevonását a közigazgatásba. A nemzetközi közösség tehát ,igazodott” a koszovói helyzethez és - elveit részben feladva - 1999. december 15-én a fömegbízott aláírta a Vegyes Ideiglenes Igazgatási Struktúráról (Joint Interim Administrative Structure - JIAS) szóló megállapodást. (Halász [2005/b.] p. 14.) A JIAS központi intézménye az Ideiglenes Igazgatási Tanács (Interim Administrative Council - IAC) volt, amelynek tagja volt a nemzetközi közösség részéröl a főmegbízott, legfőbb helyettese, a II., III. és IV. pillért vezető főmegbízott-helyettesek, a helyiek részéről pedig három albán politikus és egy személy a szerb kisebbség képviseletében. A szervezet hivatalosan konzultációs-tanácsadó testületként funkcionált volna, valójában azonban döntéshozó és kvázi jogalkotó szerepe lett. Három eszközzel biztosította azonban magának a nemzetközi közösség a primátust: az első ilyen eszköz az volt, hogy a főmegbízott mondta ki továbbra is minden döntés esetében a végső szót, a második pedig az, hogy az új struktúrában az egyes részlegek vezetői annak a pillérnek tartoztak jelentéstételi kötelezettséggel, amelynek portfóliójába az adott tevékenység tartozott. A harmadik eszközként kialakult a közigazgatás központi és 
önkormányzati intézményeiben az ún. double-desk rendszer, vagyis hogy a fontos pozíciókban egy helyi és egy nemzetközi tisztviselö együtt látta el az adott feladatot.

Ebben az időben egyéb átalakításra is sor került: a KTC esetében ekkor orvosolták az összetételében sokat kritizált hiányosságot, és a civil szervezetek képviselői is részt vehettek a testület munkájában. A KTC szerepét azonban nem módosították, továbbra se vonták be a törvényhozói munkába és nem vett részt közvetlenül a közigazgatás kialakításában és működtetésében sem. (Zaum [2007] p. 136.)

Az első fömegbízott, aki maradandó nyomot hagyott Koszovóban - és azon kevesek egyike, akik kitöltötték teljes megbízatási idejüket -, Bernard Kouchner volt, a francia orvos, aki annak idején az Orvosok Határok Nélkül (Médecins sans Frontières) nevü szervezetet megálmodta és megalapította. Kouchner fáradhatatlannak bizonyult feladata ellátása során, s az a vélemény alakult ki róla, hogy az etikai szempontokat, az igazságosságot és a jogszerüséget koszovói munkája során is fontosabbnak tartotta, mint a reálpolitikai megfontolásokat. (King-Mason [2006] p. 51.) Ez nem feltétlenül vált hasznára az UNMIK-nak, s bár Kouchner igen nagy tiszteletnek örvendett a koszovóiak és a nemzetközi tisztviselők között is, a nemzetközi igazgatás kiépítésében nem ért el jelentős sikereket ebben az időszakban. Az UNMIK azonban sikeresen teljesítette a háború utáni első jelentős feladatát a háborúban keletkezett anyagi károk helyreállítása és a visszatérő menekülteknek nyújtott gyors humanitárius segítség területén. Ezt követően - az első időszak végére - a nemzetközi közösség figyelme az egyre sürgetőbb politikai és gazdasági kérdések felé fordult.

3.2.2.2. Második szakasz: 2000. október - 2002. június (a nemzetközi igazgatás konszolidálása)

A két szakasz közti korszakhatár jelentős eseménye egy, a regionális környezetben bekövetkező jelentős változás volt: Szerbiában ugyanis 2000 októberében megbuktatták Miloševićet, s ennek következtében felcsillant az UNMIK számára a Belgráddal folytatott érdemi párbeszéd megkezdésének lehetősége. A 2000. decemberi parlamenti választás az ellenzéki erők győzelmét hozta, 2001 nyarán pedig kiadták Miloševićet a hágai törvényszéknek. Ebben az időszakban - 2001 tavaszától őszéig - a szomszédos 
Macedóniában a lakosság egynegyedét kitevő ottani albánság ${ }^{202}$ és a többségi szlávortodox macedónok között kirobbant fegyveres konfliktus újabb fenyegetést jelentett a regionális biztonságra, s aggodalommal töltötte el a világ közvéleményét egy új, a koszovóihoz hasonló konfliktus lehetősége a Balkánon. A nemzetközi közösség közbenjárásával végül megállapodás született a macedónok és az albánok között. ${ }^{203}$

Ami a tartomány belső helyzetét illeti, ebben a szakaszban már nem a visszatérő menekültek elhelyezése jelentette a legföbb problémát, hanem a mindennapokban tapasztalható áramkimaradások, a felújítások és építkezések terén tapasztalható szervezetlenség és az e területen burjánzó illegális vállalkozások.

Koszovóban az UNMIK ebben az időszakban - Haekkerup és Steiner főmegbízottak hivatali ideje alatt - jelentős előrelépést tett a nemzetközi igazgatás megszilárdítása terén, s megkezdődött az önigazgatás helyreállításának folyamata is. Az önigazgatás fokozatos biztosításának következő lépése az ideiglenes struktúra intézményei helyett legitim, a jogállamiság keretei között választott intézmények létrehozása volt. 2000 októberében tartották Koszovóban a helyhatósági választásokat - hasonlóan, mint Boszniában a kilencvenes évek második felében -, a nemzetközi sztenderdeknek megfelelően és szoros felügyelet mellett. ${ }^{204} 2001$ januárjában az Európa Tanács Velencei Bizottságának közremüködésével megszövegezték az „,alkotmánytervezetet”. Az idézőjel indokolt: Koszovó nem volt szuverén állam, így nem lehetett alkotmánya sem. A tervezetet elfogadta a Kvintett (Quint States) és az ENSZ Titkársága is, ezután vitatta meg egy vegyes összetételü, tizenhárom tagú munkacsoport. ${ }^{205,206}$

\footnotetext{
${ }^{202}$ Macedóniában a hivatalos adatok szerint a lakosság 25\%-a albán, de ma már valószínű, hogy az albánok aránya a lakosságon belül inkább egyharmadnyi, semmint egynegyednyi. Az albánok pedig akár még 40-\%-ot is meghaladó mértéküre is becsülik arányukat.

${ }^{203}$ A konfliktust végül erős nemzetközi nyomásgyakorlás mellett az Ohridi egyezménnyel zárták le, amelyben rendelkeztek a politikai hatalommegosztásról a kisebbségi albánság és a többségi macedón szlávság között.

${ }^{204}$ Ebben a szakaszban fontos eredményeket ért el a nemzetközi igazgatás több, különösen problémás területen: az útlevelet helyettesítendő az UNMIK által kibocsátott ún. utazási dokumentumot adtak a lakosságnak; bevezették hivatalos fizetőeszközként az eurót és ebben az időszakban megindult a párbeszéd Belgráddal is.

${ }^{205}$ A munkacsoportnak hét koszovói tagja (öt albán, egy szerb és egy boszniai) volt, a nemzetközi közösség pedig hat tagot delegált.

${ }^{206}$ A munkacsoport elé került a koszovói albánok által készített alkotmánytervezet is, amelyet azonban azzal az indokkal utasítottak el, hogy az 1244-es BT-határozat értelmében a tartomány státusza ezt nem teszi lehetővé. Szintén elutasította a testület az albánok azon kérését, hogy a fömegbízott tartozzon elszámolással az alkotmánybíróság felé, s elvetette a koszovói függetlenségről szóló referendum kiírására tett javaslatot is.
} 
2001. május 15-én a főmegbízott rendeletet adott ki, amely tartalmazta az Ideiglenes Önigazgatás Alkotmányos Keretét; ez úgy változatta meg az addigi struktúrát, hogy a tartomány tovább mozdult abba az irányba, hogy lakosai maguk döntsenek sorsukról az alkotmányos jogállamiság keretei között rendelkezésre álló demokratikus intézmények segítségével. Az új struktúra neve az Ideiglenes Önigazgatás Intézményei (Provisional Institutions of Self-Governance - PISG) lett, központi elemei pedig a kormány, a köztársasági elnök és a parlament, valamint a minisztériumok. Az új rendszerben a PISG számos feladatot átvett az UNMIK-tól, amely utóbbi kezében azonban még mindig elég hatalom maradt, hogy alapvetően befolyásolhassa a koszovói politikai folyamatokat. Az 1999/1-es rendelet alapvető mérföldkövét ugyanis nem mozdították: a végső szót továbbra is az UNMIK (a főmegbízott) mondta ki minden egyes jogalkotási aktus esetében. Ráadásul az államiság kulcsterületeinek számító alapvető jelentőségű politikák esetében a PISG-nek történő hatalomátadás még részben sem történt meg, ezek: rendőrség és igazságszolgáltatás, állami vagyon kezelése és privatizációja és külkapcsolatok. Ahogy Tansey fogalmaz: „Az önigazgatás létezett Koszovóban, de nem érte el azt a szintet, hogy demokratikusnak nevezhetnénk.” (Tansey [2009] p. 134.)

Az új struktúra kapcsán időszerü volt megreformálni a pilléres szerkezetet is: az I. pillérbe addig tartozó, UNHCR által felügyelt humanitárius ügyek nagyrészt aktualitásukat vesztették, hiszen 2001-re a menekültek jelentős része visszatért Koszovóba, s a háború során az infrastruktúrában végbement pusztítások helyreállítása is kilépett abból a szakaszból, amikor a lakosság alapvető szükségleteinek biztosítása (pl. lakóházak beköltözhetővé tétele) volt a cél. Az új I. pillérbe került így a rendőrség és az igazságszolgáltatás.

$\mathrm{Az}$ új rendszerben a jogalkotás kettőssége érvényesült. Egyrészt az UNMIK hatáskörében maradt területeken a felelős pillérektől származó tervezetet a főmegbízott és az ENSZ jogi tanácsadóinak véleményezése után (ha megfelelö) a fömegbízott aláírja és rendeletben kihirdeti. Másrészt a PISG felelősségi körébe tartozó ügyekben a jogszabály-kezdeményező lehet a felelős szakminisztérium, a miniszterelnök vagy a parlament, de minden jogszabályt jóvá kell, hogy hagyjon a fómegbízott is. (Zaum [2007] p. 141.) 
2001. szeptember 11-én az Amerikai Egyesült Államok ellen intézett támadást követően kialakult nemzetközi helyzet azzal a veszéllyel fenyegetett, hogy az új, terrorizmus elleni harc megindítása marginalizálja a Balkán térségét, $\mathrm{s}$ így a koszovói státusztárgyalások előmozdítását is. Ugyanakkor a térségre irányuló kevesebb figyelem egyben kisebb nyomást is jelentett a koszovói nemzetközi adminisztráció vezetőinek, $\mathrm{s}$ lehetőséget nyújtott számukra, hogy átgondolják a nemzetközi igazgatás és a státuszkérdések jövőjét. Nyilvánvaló azonban az aránytalanság az előnyök és a hátrányok felsorolásánál: a kialakult helyzet 2001 szeptembere után Koszovó számára sokkal több fenyegetést hordozott magában, mint lehetőséget, ez utóbbi kihasználása ráadásul attól függött, hogy az UNMIK valóban képes lesz-e struktúráját és prioritásait a változó körülményekhez igazítani.

\subsubsection{Harmadik szakasz: 2002. június - 2004. február (stagnálás, az ellentétek fokozódása)}

A korszakhatárt a konszolidáció és a stagnálás időszaka között a koszovói kormány beiktatása jelzi 2002 júniusában. Az UNMIK az ezt követő időszakban sajnos nem tudott megfelelni az előző szakasz végén említett kihívásoknak, és nem volt képes megszilárdítani helyzetét Koszovóban.

Mindenekelőtt röviden bemutatjuk a koszovói ideiglenes önigazgatás központi intézményeit, a kormányt, a parlamentet és a köztársasági elnököt. Ennél a résznél alapvetően arra törekszünk, hogy az egyes intézményekről ma is érvényes információkat közöljünk, ha a PISG-intézmény és jelenlegi megfelelője között különbség van, akkor azt külön jelezzük. A kormány (kabineti qeveritar) a meglehetősen széles jogkörökkel bíró miniszterelnökből ${ }^{207}$ és a kabinetből $1^{208}$ áll, felépítésében pedig tükrözi Koszovó etnikai viszonyait és törekszik arra, hogy a kisebbségeket is pozícióhoz juttassa. Ennek érdekében a kormányban legalább egy-egy miniszter és kettő-kettő miniszterhelyettes a koszovói szerb közösség és más kisebbségi népcsoport tagja, s ha a miniszterek létszáma 12 fölé emelkedik, akkor még egy helyet

\footnotetext{
${ }^{207}$ A miniszterelnök jelenleg Hashim Thaçi.

${ }^{208}$ A kabinet tagjai a miniszterelnök, helyettesei és a miniszterek. Jelenleg Koszovóban az alábbi portfóliók tartoznak egy-egy minisztériumhoz: külügy; európai integráció; igazságügy; belügy; kultúra, ifjúság és sport; oktatás, tudomány és technológia; önkormányzatok; közigazgatás; infrastruktúra; mezőgazdaság; egészségügy; munkaügy és szociális jóléti ügyek; kommunikáció és visszatérési ügyek; diaszpóra. (Koszovó miniszterelnöki hivatala [é. n.])
} 
kell garantálni a kisebbségeknek mind a miniszterek, mind helyetteseik között. A választások után a nyertes pártokkal folytatott konzultációt követően tesz javaslatot a köztársasági elnök a parlamentnek a miniszterelnök személyére, utóbbiról az általa kijelölt miniszterekkel együtt szavaz a parlament. (A regnáló kormányban történő esetleges személycserékről ezt követően a miniszterelnök saját hatáskörben dönthet.) (Koszovó alkotmánya [2008] VI. fejezet) Az államfó ${ }^{209}$ (presidenti) személyében a koszovói nép egységét testesíti meg, minden 35. életévét betöltött koszovói állampolgár indulhat a köztársasági elnöki választásokon, személyéröl a parlament 2/3-dal dönt, hivatali ciklusa öt év. ${ }^{210}$ (Koszovó alkotmánya [2008] V. fejezet) A közvetlenül négy évre $^{211}$ választott koszovói parlament (Kuvendi i Kosovës) 120 tagból áll, a képviselői helyek egyhatoda (20 hely) a vallási és etnikai kisebbségek tagjainak van fenntartva. ${ }^{212}$ PISG-intézményként korábban a parlament elnöksége hét tagból állt, (Halász [2005/b.] p. 19.) mára ez úgy módosult, hogy a parlament elnökét a választásokon legtöbb szavazatot szerzett párt jelöli (a képviselők pedig egyszerü többséggel megválasztják), az öt elnökhelyettesi poszt összetétele pedig részben a politikai erőviszonyokat, részben pedig az etnikai összetételt tükrözi. ${ }^{213}$

A vezető politikai intézmények bemutatása után térjünk vissza ismét a nemzetközi igazgatás 2002-2004-es időszakának bemutatásához. Ebben a szakaszban számos tényező hozzájárult ahhoz, hogy az UNMIK számára kedvezőtlenül változott a regionális környezet. Mindenekelőtt változás állt be a koszovói albánok és az UNMIK viszonyában, utóbbi legitimitása a helyiek szemében ugyanis egyre csökkent. Ezt több tényező is magyarázza: elsősorban az, hogy időben egyre messzebb került a NATObeavatkozás. Az albánok az intervencióért ugyan továbbra is hálásak voltak a nemzetközi közösségnek, az UNMIK azonban egyre inkább az önrendelkezési folyamat gátjának, semmint előremozdítójának tűnt az albánok szemében. A nemzetközi igazgatás legitimitása többé vagy kevésbé, de minden esetben bizonyos mértékben

\footnotetext{
${ }^{209}$ A jelenlegi államfö Atifete Jahjaga asszony. (Koszovói államfő hivatala [é. n.])

${ }^{210}$ PISG-intézményként az államelnöki megbízatás még csak három évre szólt.

${ }^{211}$ Ideiglenes intézményként korábban a parlament mandátuma három évre szólt.

${ }^{212}$ A 20 kisebbségi képviselői helyből 10 a szerbeké, az alábbi közösségek pedig az alábbiak szerint jogosultak parlamenti helyekre: roma (1hely); askáli (1hely); egyiptomi (1 hely) - a három közösség ezen felül együttesen plusz egy helyre jogosult, s ezt ténylegesen az a kisebbségi csoport kapja közülük, amely a választásokon a legtöbb támogatást szerezte meg; bosnyák ( 3 hely); török ( 2 hely); goráni (1 hely). (Koszovó alkotmánya [2008] IV. fejezet, 64. cikk)

${ }^{213}$ A öt parlamenti elnökhelyettes közül hármat a három legtöbb szavazatot szerzett párt delegál, kettőt pedig a nem többségi közösségek (egy hely jut a szerbeknek, egy pedig a többi etnikai és vallási közösségnek). (Koszovó alkotmánya [2008] IV. fejezet, 67. cikk)
} 
megkérdőjelezhető, s igaz az állítás a koszovói esetre is. Az UNMIK jelenlétének szükségességét - a kezdettől fogva elutasító koszovói szerbségen túl - egyre több koszovói albán kezdte kétségbe vonni. Ráadásul a demokratikus választásokat követően felállt a nemzetközi közösség nagy része által immáron legitimnek elfogadott ${ }^{214}$ koszovói kormányzat, s a tartomány nagy lépést tett elöre az önrendelkezés megvalósulása felé. A koszovói albánok közül egyre többen vélték úgy, hogy most már a nemzetközi közösség bábáskodása nélkül is képesek rendelkezni saját sorsuk felett.

2002-2003-ban a koszovói parlament és az SRSG több kérdésben is szembekerült egymással, mindegyik esetben a vita végül azzal zárult, hogy a különleges megbízott hatalmi szóval lezárta a vitát. Az egyik ilyen feszültséget generáló kérdés a parlament azon határozattervezet volt, amelyben a testület síkra szállt a koszovói területi integritás mellett. Mivel a kérdés érzékenyen érintette Koszovó határait és így külkapcsolatait Macedóniával, ezért az SRSG megsemmisítette az egyébként ki is hirdetett határozatot. Így döntött a különleges megbízott akkor is, amikor a parlament egy olyan határozatot igyekezett elfogadtatni, amelyben elismerik az UCK háborús érdemeit. ${ }^{215} \mathrm{~A}$ legjelentősebb ellentét azonban a két intézmény között akkor bontakozott ki, amikor a parlament az Alkotmányos Keret módosítása nyomán megkísérelte az SRSG és a nemzetközi igazgatás jogköreit korlátozni és a státuszkérdés ügyében döntést kicsikarni. A végső jóváhagyásra az SRSG elé terjesztett jogszabály-tervezet jóváhagyását a különleges megbízott megtagadta, s így ismét bebizonyította, hogy él vétójogával azokban az esetekben, amikor az ideiglenes intézmények nem a rendezési elveknek megfelelő szellemiségben vagy kompetenciájukon túlnyúlóan kívánnak tevékenykedni. (Tansey [2009] pp. 137-138.)

Változott a nemzetközi igazgatás maga is, s a változás tovább rontotta az amúgy is egyre kevésbé népszerű UNMIK ${ }^{216}$ megítélését is. Egyre inkább szembetűnő volt ugyanis a csökkenő lelkesedés a nemzetközi tisztségviselők esetében, s hiába állt ebben az időszakban egy különösen lelkes főmegbízott az UNMIK élén, még neki sem sikerült

\footnotetext{
${ }^{214}$ A koszovói albánok már a kilencvenes években több alkalommal kikiáltották függetlenségüket, sőt 1992 májusában parlamenti és elnökválasztásokat is tartottak. Akkoriban sem a szerbek, sem pedig a nemzetközi közvélemény nem ismerte el legitimnek sem a választásokat, sem az annak eredményeképpen felállított kormányt.

${ }^{215}$ A szerbek a határozat beterjesztését követően azonnal kivonultak a parlamentböl.

${ }^{216}$ A kétezres évek elejére a helyiek körében elterjed Koszovó gúnyneve: Unmikisztán. (Lémay-Hébert [2009]. p. 69.)
} 
intenzívebb munkára ösztönöznie csapatát. Pedig Steiner fömegbízott ugyancsak nagy reményekkel kezdett hozzá az UNMIK szerinte legsürgetőbb feladatainak megvalósításához. Steiner gyakorlatilag minden fontos feladatot napirendre vett, ${ }^{217} \mathrm{~S}$ ekkor fogalmazták meg az ún. sztenderdeket (standards) is. Ezek a sztenderdek olyan célokat jelöltek meg, amelyek megvalósítása a nemzetközi közösség véleménye szerint a háború utáni normalizációnak és Koszovó demokratizálásának legfőbb záloga. 2002ben a nemzetközi közösség arra az álláspontra helyezkedett, hogy a sztenderdek megvalósítása - és különösen a több, mint százezer, föként szerb menekült visszatérésének biztosítása és jogainak védelme; a decentralizáció és a demokratikus intézményrendszer kiépítése - az elsődleges, s amíg nem valósulnak meg az abban foglaltak, addig nem kezdődhetnek meg a tárgyalások Koszovó végleges státuszáról (erre utalt a standards before status kifejezés). (Zaum [2007] p. 142.) Ehhez az elvhez 2004-ig ragaszkodtak, akkor azonban a koszovói események hatására kénytelenek voltak felülbírálni addigi álláspontjukat.

Steiner céljai valóban a legsürgetőbb megoldást igénylő problémákat fogalmazták meg, jelentős előrelépést azonban neki sem sikerült elérnie. Öt ráadásul Harri Holkeri követte a főmegbízotti székben, aki nemhogy nem lépett előre az UNMIK megítélésének javítása területén, de passzív magatartásával még tovább rontotta azt. (King-Mason [2006] p. 139-141.)

Szintén ebben az időszakban változás állt be a szerb belpolitikában is, a szerbiai választásokat ugyanis a nemzeti kérdésekben radikálisabb álláspontot képviselő jobboldal nyerte, így nem lehetett számítani arra, hogy a koszovói státusztárgyalásokban elörelépés történik.

A koszovóiak tehát egyre kevésbé támogatták az UNMIK koszovói jelenlétét, az UNMIK pedig - a nemzetközi közösség és közvélemény egyre lanyhuló érdeklődése mellett - egyre kevésbé tünt képesnek arra, hogy a fontos kérdésekben, mindenekelőtt a tartomány státuszának ügyében, előremozdítsa a folyamatokat. Ebben a koszovóiak már nem hittek, s látszólag az UNMIK maga sem. A csalódott koszovóiak számára ebben a

${ }^{217}$ Steiner szerint a megoldandó feladatok listája a következő volt: Mitrovica, decentralizáció, PristinaBelgrád párbeszéd, menekültek visszatérése, az illetékesség delegálása egyre több ügyben a helyi intézményeknek, a gazdasági és társadalmi helyzet javítása, UNMIK megreformálása, az európai integráció előmozdítása, sztenderdek. (King-Mason [2006] p. 140.) 
feszült helyzetben bármilyen esemény vezethetett az erőszak kirobbantásához. 2004 tavaszán ez az esemény be is következett.

Koszovóban a szerbek és az albánok között szórványosan már 2004 tavasza előtt is előfordultak fegyveres incidensek (merényletek, robbantások), többször intéztek támadásokat föként a kisebbségek tagjai ellen, de koszovói albánok ellen is. Március hónapban - a NATO-bombázások megindulásának évfordulóján - minden évben gyakoribbak voltak ezek az incidensek, s különösen számítani kellett arra, hogy a feszültség fokozódik, így volt ez 2000 óta minden évben. Kezdetben nem tűnt úgy, hogy az előző évekhez képest súlyosabb válságra nem kell számítani 2004-ben, március 17-én azonban három albán kisfiú halála felkorbácsolta az indulatokat. ${ }^{218}$

Ez a tragikus eset hatalmas - kezdetben spontán, de aztán rövid időn belül jól szervezett - tiltakozás-sorozatot indított el Koszovó-szerte, amelynek mentén a háború óta nem látott erőszakhullám söpört végig a tartományon. A támadások célpontjai elsősorban a szerb kisebbség tagjai és a szerbek tulajdonában álló lakóházak voltak, valamint a szerbek számára fontos emlékhelyek. Az „eredmény” pedig a körülbelül egy hónapos zavargást követően: mintegy 20 halott és több, mint 1000 sebesült; 4000 elüldözött szerb vagy valamely más kisebbséghez tartozó koszovói lakos; 700 megrongált vagy elpusztított lakóház, 36 tönkretett szerb ortodox templom vagy történelmi emlékhely. (King-Mason [2006] p. 5., 189.)

Azon túl, hogy a 2004. márciusi események bebizonyították a nemzetközi közösségnek, hogy Koszovó továbbra is potenciális veszélyforrás Európa biztonságát illetően, volt még egy fontos jellemzője a zavargásoknak. Első alkalommal fordult elő ugyanis, hogy a koszovóiak nyíltan szembeszálltak, sőt fegyveresen támadtak a nemzetközi közösség

\footnotetext{
${ }^{218}$ Az albán gyerekekböl álló csoport az Ibar-folyó mentén sétált, amikor három gyermek valamilyen okból a megáradt folyóba menekült, s életét vesztette. Mint minden ilyen eseménynél, itt is különböző vélemények keringtek az okokat illetően - és aztán merevedtek szilárd meggyőződéssé - az egyes véleményalkotó csoportok körében. Az események pontos rekonstrukciója itt sem történt meg, bizonyosan hibákat is elkövettek az ügyben nyomozó helyi és nemzetközi hatóságok. A leginkább valószínűnek az tűnik, hogy a hat gyerek közül négyen valamitől megijedve a folyóba vetették magukat, ahonnan csak egyiküknek sikerült élve kijutnia. A túlélő fiú arról számolt be, hogy szerbek kiabáltak rájuk, s fenyegették őket, ettől ijedtek meg. Más vélemények szerint a gyerekek kutyáktól ijedtek meg. Azt a két fiút, akik a csoportból nem gázoltak a folyóba, senki nem kérdezte meg, vagy ha igen, vallomásuk nem került nyilvánosságra. (King-Mason [2006] pp. 9-10.) Ami bizonyos, a hír - miszerint felböszült szerbek csoportja a halálba kergette az albán gyerekeket - villámgyorsan terjedt, s a hangulat felkorbácsolásához igen hathatósan járult hozzá több albán elektronikus és később írott médium is, sőt helyi és tartományi vezető politikusok. Felelősségüket sem akkor, sem később nem vizsgálták.
} 
jelen levő képviselőire. A fegyveres incidensek során ugyan elsősorban a KFOR alakulatai kerültek szembe a zavargásokban részt vevő koszovóiakkal, mégis azt mondhatjuk, hogy az albán többségi lakosság ellenszenve sokkal inkább az UNMIK ellen irányult, s kevéssé a KFOR ellen. (A KFOR továbbra is az a nemzetközi biztonsági erő volt, amely megakadályozta, hogy Belgrád ismét megszerezze az irányítást a tartomány felett.)

Meg kell azt is jegyeznünk, hogy az UNMIK és a KFOR sem reagált megfelelően és elég gyorsan a 2004. márciusi eseményekre. A KFOR vezetői például kezdetben úgy vélték, hogy a nemzetközi rendőrség hatáskörébe tartozik a zavargások megfékezése, az UNMIK vezetői pedig nem tudtak hitelesen hozzájárulni a helyzet normalizálásához, s ezáltal javítani saját megítélésüket. Az erőszak megfékezését követően pedig nemcsak a koszovóiak maradtak adósok az elkövetök felkutatásával és felelősségre vonásával, de a nemzetközi adminisztráció sem tett semmit ezen a területen.

Megállapíthatjuk tehát, hogy alulbecsülték a veszélyt a nemzetközi közösség képviselői Koszovóban, s ezzel ugyanazt a hibát követték el, mint addig már számos alkalommal a Balkánon a kilencvenes évek óta: 2004 tavaszán is megtörtént ugyanis, hogy az elkényelmesedett és ambícióját vesztett nemzetközi közösséget egy helyi erőszakos eseménysorozat ösztönözte cselekvésre és a Balkánnal kapcsolatos politika átgondolására.

3.2.2.4. Negyedik szakasz: 2004. március - 2008. február (státusztárgyalások és kudarcok)

A 2004. márciusi események tehát mindenképpen szakaszhatárnak tekintendőek a koszovói nemzetközi igazgatás történetében, az ezt követő időszakban sokkal reálisabb megközelítés jellemzi a nemzetközi közösséget, s valójában 2004 óta megkezdődött a nemzetközi közösség lassú kivonulásának elökészítése is. A legnagyobb paradigmaváltásnak a sztenderdekről való lemondást tekinthetjük: eddigre ugyanis világossá vált, hogy a sztenderdek maradéktalan teljesítése nem lehet feltétele a státusztárgyalások megkezdésének. Legfőképpen azért nem, mert teljesítésük korántsem haladt olyan ütemben, ahogyan a nemzetközi közösség azt vizionálta, egyre nőtt viszont a koszovói albánok türelmetlensége és aggodalma, hogy bennszorulnak ebben a 
szerintük köztes helyzetben. A sztenderdek nem teljesítése a nemzetközi közösség és a koszovóiak közös felelőssége. Előbbi felelőssége abban áll, hogy a sztenderdek megállapítása a nyugati értelemben vett érett demokráciák karakterisztikáit tükrözte vissza, s elvárásként fogalmazta meg ezeket egy olyan társadalommal szemben, amely Európában az egyik legszegényebb volt és maradt, $\mathrm{s}$ ahol a civilizációs-kulturális jellemzők és örökségek, valamint a közelmúlt történelmi sérelmei lassabb adaptálást tettek volna lehetővé. A nemzetközi adminisztráció nem vette figyelembe ezeket a körülményeket, s erőfeszítései sem bizonyultak elegendőnek ahhoz, hogy a sztenderdekben megfogalmazott elvek szerint müködő társadalmat építsenek Koszovóban.

A standards before status helyébe 2004-2005-ben a standards light politika lépett, (King-Mason [2006] p. 192.) később általában a kevésbé cinikus status before standards kifejezés vált általánossá. Ekkorra tehát a nemzetközi közösség letett arról a 2002-ben megfogalmazott szándékáról, hogy megköveteli a sztenderdek tételes teljesítését a koszovóiaktól, mielőtt elindítja a tartomány végleges státuszáról szóló tárgyalásokat, s utóbbit nem tette az előbbiek megvalósulásának feltételévé, hanem a párhuzamos megvalósítás mellett döntött.

Az első jelentős lépés az első Eide-jelentés jelenti ebben az irányban, 2004 júliusában. Kofi Annan ENSZ főtitkár ugyanis Kai Eide norvég diplomatát kérte fel, hogy készítsen jelentést arról, hogy mi történt Koszovóban 2004 tavaszán és értékelje a helyzetet. A jelentésben a raportőr megállapította, hogy ,,a jelen politika statikus és nem alkalmas arra, hogy Koszovó valós problémáira megoldást találjon”, Eide ezért azt javasolta, hogy radikálisan reformálják meg az addigi stratégiát és haladéktalanul kezdjék meg a státusztárgyalásokat. (Eide-jelentés [2005]) Az új irány végrehajtására megfelelően ambiciózus - és elődjéhez képest mindenképpen energikusabb - főmegbízottat is találtak Søren Jessen-Petersen dán diplomata személyében.

2005 áprilisában a Kontakt Csoport megfogalmazta azokat az elveket, amelyek mentén a koszovói státusztárgyalásokat folytatni kell. Megfogalmazták többek között, hogy a megoldás során nem lehet visszatérni az 1999 előtti állapotokhoz; de nem lehet felosztani sem a tartományt, határai tehát megváltoztathatatlanok; Koszovó nem csatlakozhat más államokhoz; s multietnikus jellegét meg kell őrizni. Azt is leszögezték, 
hogy a tárgyalások eredményeként olyan megoldás fogadható csak el a nemzetközi közösség számára, amely a két fél megállapodásának eredményeként születik, egyoldalú megoldást (népszavazást, fegyveres erőszakot) tehát nem lehet alkalmazni. (Háry [2007] p. 14.)

A tárgyalások koordinálásával az ENSZ főtitkára Marti Ahtisaari korábbi finn államfőt, egy tapasztalt diplomatát bízott meg, akinek ráadásul balkáni tapasztalata is volt már korábbról. A tárgyalások 2006. január 25-én kezdődtek meg Bécsben, s több fordulón keresztül zajlottak, a felek álláspontjai azonban nem közeledtek. A koszovói albánok mind a mérsékeltebb, mind pedig a radikálisabb politikai formációk - számára az egyetlen lehetséges megoldás a függetlenség volt, a szerbek viszont egy igen széleskörü autonómiával bíró Koszovót vizionáltak, amely továbbra is Szerbia része maradt volna. A belgrádi „autonómiánál több, függetlenségnél kevesebb” megoldási elképzelés részeként a szerbek saját irányítású közigazgatási egységeket akartak létrehozni azokon a koszovói területeken, ahol nemzettársaik éltek, s amelyek nemzeti etnohistorikus emlékezetük fontos helyszínei voltak. (elsősorban egyes északi, középső és keleti részeken, benne Peć és Prizren annak ellenére, hogy ott a lakosság már nem szerb többségü). Az említett területeken az oktatás, a közlekedés, a bíráskodás és a rendőrség a szerbek irányítása alá került volna, s a rendezés részeként a szerbek visszakövetelték volna a második világháborút követően a partizánok által kisajátított egyházi birtokokat is.

A sikertelen tárgyalásokkal párhuzamosan a nemzetközi közösség néhány befolyásos tagja is kinyilvánította véleményét, s világossá vált, hogy a nemzetközi közösség maga sem egységes Koszovó jövőjét illetően, ez pedig előrevetítette, hogy a fontos nemzetközi döntéshozó fórumokon (pl. ENSZ BT) sem lesz egyetértés a kérdésben. Az Amerikai Egyesült Államok szerint a koszovói népnek magának kell saját sorsáról döntenie (lényegében ez az albánok támogatását jelentette), Oroszország viszont Szerbia szuverenitásának és területi épségének hangsúlyozásával és azzal, hogy többször kijelentette, számára csak olyan megoldás elfogadható, amellyel mindkét fél elégedett, valójában a szerbek oldalára állt. Az Európai Unió tagállamai közül Spanyolország, Szlovákia, Románia határozottan ellenezték Koszovó függetlenségét, de nem támogatta 
a koszovói albánok önállósodási törekvéseit Görögország, Ciprus és Bulgária sem. ${ }^{219} \mathrm{~A}$ függetlenség legfőbb támogatója az uniós tagállamok közül Nagy-Britannia, de Németország és Franciaország is függetlenségpártinak bizonyult. Szerbia 2006 őszén sajátos módon tette álláspontját újfent egyértelművé: szeptember 30-án a parlament elfogadta az új alkotmányt, amelyben az áll, hogy Koszovó Szerbia integráns része. Az alaptörvény legitimitásának megerősítése érdekében népszavazást is tartottak október 28-29-én, ahol 54,9\%-os részvétel mellett (az albánok nem szavaztak), 53,04\%-os támogatással, megerősítették az új alkotmányt.

A sikertelen tárgyalásokat követően 2007. január 25-én Ahtisaari az ENSZ főtitkárának - február 2-án pedig az albánoknak és a szerbeknek is - bemutatta tervét a koszovói rendezésről. Az Ahtisaari-tervként ismertté vált dokumentum alapján kezdődtek meg ismét a tárgyalások Bécsben, 2007 márciusában. A terv egyfajta „,nemzetközileg felügyelt függetlenséget” irányzott elő anélkül, hogy nyilvánvalóvá tette volna, hogy nemzetközi jogilag Koszovó államisága és a szuverenitás tekintetében mit is jelent ez pontosan. Az elképzelés tartalma már világosabb volt: Koszovó nem kerül vissza Szerbiához, nemzetközi felügyelet alatt maradna, de a nemzetközi igazgatás jellege és szerepe jelentősen megváltozna. Megszünnének ugyanis a nemzetközi civil adminisztráció végrehajtó jogosítványai és közvetlen irányító szerepe is, s az UNMIKot új struktúra váltaná fel egy nemzetközi civil képviselő irányítás alatt és az EU vezetésével, amelynek fó feladata a jogállamiság megteremtésének támogatása és a demokratikus intézményrendszer elemeinek fejlesztése lenne. A nemzetközi biztonsági jelenlét nem szünne meg, a KFOR továbbra is a térségben maradna, s Ahtisaari szerint egy, az 1244-es BT határozatot felváltó nemzetközi jogi dokumentum (lehetőség szerint egy új BT határozat) adna megfelelő legitimitást az új struktúrának. (Ahtisaari-terv [2007])

A tárgyalások során továbbra sem körvonalazódott a kompromisszumos megoldás, később a Kontakt Csoport és az ún. trojka (Európai Unió, Amerikai Egyesült Államok és Oroszország) is igyekezett közvetítőként elöremozdítani a tárgyalásokat sikertelenül. 2007. december 10-én eredménytelenül zárult Koszovó státuszáról a tárgyalási folyamat.

${ }^{219}$ Az ellenzők köre ma is ezeket az államokat foglalja magába, kivéve Bulgáriát, amely elismerte Koszovót szuverén államnak. 
Amint az ismeretes, 2008. február 17-én - a szerbiai parlamenti választásokat követően - a pristinai parlament egyoldalú aktussal kikiáltotta Koszovó függetlenségét. Ugyanebben az évben megkezdődött az UNMIK-ot fokozatosan felváltó EULEX telepítése.

\subsection{Biztonság}

A koszovói válság - és egyben a 77 napig tartó NATO-bombázás - lezárásakor két dokumentumot írtak alá illetve fogadtak el, amelyek rendelkeztek a katonai-biztonsági intézkedésekről: a kumanovói technikai-katonai megállapodást és az 1244-es BT határozatot. A BT határozatról a fentiekben már írtunk, ebben a fejezetben röviden ismertetjük a kumanovói megállapodás tartalmát, amely részletesen szabályozza a nemzetközi biztonsági erők helyszínre településének folyamatát.

1999. június 9-én a nemzetközi erők egyrészről, a Jugoszláv Szövetségi Köztársaság és a Szerbia Köztársaság másrészről aláírta a katonai-technikai megállapodást (Military TechnicalAgreement between the International Security Force ["KFOR"] and the Government of the Federeal Republic of Yugoslavia and the Republic of Serbia). A dokumentum I. cikkébern a JSzK és Szerbia kormányai tudomásul veszik, hogy az 1244-es BT határozat rendelkezéseinek megfelelően nemzetközi katonai erők települjenek a tartományba a biztonság szavatolásának érdekében. Szintén ebben a cikkben rendelkeznek még a légi és a földi biztonsági zónákról, ${ }^{220}$ ahová tilos volt a jugoszláv légierő és a haderő belépése. (Kumanovói megállapodás [1999])

Az ellenségeskedések felszámolásáról szóló II. cikkben a jugoszláv erők azonnali kivonulásáról rendelkeznek. A kivonulás több, a dokumentumban részletesen ütemezett fázisból állt, s a kivonuló jugoszláv szárazföldi és légierők helyére folyamatosan települtek a KFOR (Kosovo Force) csapatai. Kivonulásuk során a jugoszláv erőknek fel kellett szedniük az útjukba eső és általuk telepített aknákat, robbanóanyag-csapdákat

\footnotetext{
${ }^{220}$ Ezekkel a zónákkal lényegében Koszovó köré a levegőben $25 \mathrm{~km}$-es, földön pedig 5 km-es zónákat jelöltek ki a JSzK területén és légterében a koszovói tartományi határ mentén, ahová a jugoszláv erők nem léphettek. (Kumanovói megállapodás [1999])
} 
(booby trap) és a fel nem robbant lövedékeket, valamint pontosan megjelölni azokat, amelyek még a térségben maradtak. Az erre vonatkozó dokumentációt, valamint a KFOR-erők parancsnoka által kért egyéb katonai és biztonsági információkat a III. cikk rendelkezéseinek értelmében a jugoszláv katonai vezetésnek két napon belül át kellett adnia. A IV. cikk rendelkezett a KFOR-parancsnok irányítása alatt álló Vegyes Végrehajtó Bizottság (Joint Implementation Commmission - JIC) létrehozásáról, amelyet a KFOR településével egy idöben kellett felállítani. ${ }^{221}$ Az V. cikk leszögezi, hogy a megállapodás - amelynek rendelkezései pedig kötelező érvényüek az aláíró felekre nézve - végrehajtásáért a KFOR parancsnoka a felelős. A dokumentumhoz két melléklet is csatlakozik: az „A” melléklet a jugoszláv erők kivonulását részletezi, a „, $\mathrm{B}$ ” pedig a KFOR-erőkre vonatkozik. (Kumanovói megállapodás [1999])

A megállapodás rendelkezéseinek megfelelően a nemzetközi biztonsági erők feladata a koszovói biztonságos környezet megteremtése és fenntartása, s ezen célja beteljesítése érdekében a KFOR minden szükséges eszközt felhasználhat, akár katonai erőt is alkalmazhat. A KFOR-nak joga van a következőkhöz (a „B” mellékletben foglaltak alapján):

- a megállapodás rendelkezéseinek végrehajtását ellenőrizni, be nem tartásuk vagy erőszakos cselekmények esetén azonnal reagálni, ha szükséges, katonai erő alkalmazásával;

- együttmüködni a koszovói helyi és a jugoszláv polgári és katonai szervekkel;

- megfigyelni, ellenőrizni és vizsgálatot lefolytatni minden olyan létesítményben, ahol feltételezhetően katonai vagy rendőri tevékenységet folytatnak, vagy ezen tevékenységekhez más módon kapcsolódnak.

A KFOR-erők néhány nappal a válság lezárulását követően (1999. június 12-én) meg is kezdték a térségbe való települést, s 1999. június 20-ra befejeződött a jugoszláv erők kivonulása is. A KFOR-csapatok soknemzetiségü, NATO és nem NATO-tagállam országok $^{222}$ kontingenseiből álló, mintegy 50000 föt számláló erővel jelentek meg a

\footnotetext{
${ }^{221}$ Fontos leszögezni, hogy a Koszovóban tevékenykedő NATO-csapatokért és azok tevékenységéért a legfőbb felelősséget a küldő állam viseli, a NATO feladat, hogy az irányításért és koordinációért feleljen, de nincs joga pl. az egyes kontingenseket az elöre rögzített müveleti területen túlra áthelyezni. (Friedrich [2005] p. 272.)

${ }^{222}$ A dolgozat lezárásának idején (2012. augusztus) a KFOR-erők 30 ország mintegy 5600 fős kontingenséből álltak össze. A nem NATO tag hozzájáruló államok: Ausztria, Finnország, Írország, Marokkó, Örményország, Svájc, Svédország, Törökország, Ukrajna. (NATO KFOR [2012])
} 
térségben, felhatalmazásukra az ENSZ Biztonsági Tanácsának rendeletével, az Alapokmány VII. fejezete alapján került sor. Különösen fontos volt a KFOR-ban Oroszország kontingensének részvétele, amelyre az amerikai és az orosz védelmi miniszterek között 1999. június 18-án kötött megállapodás (a helsinki megállapodás) (23 $^{223}$ alapján került sor. ${ }^{224} \mathrm{~A}$ KFOR létszámát több lépésben, fokozatosan csökkentették, a koszovói biztonsági helyzet javulásának megfelelően (2002 elején 39000 főre, 2003 júniusában 26000 főre, majd 2003 végén 17500 főre). A 2004. márciusi zavargások rávilágítottak arra, hogy túlzottan optimistának bizonyult az a feltevés, hogy Koszovóban nem kell már számítani az ellenségeskedések felszínre törésére, ekkor döntöttek arról, hogy egy gyorsreagálású erőt (2 500 főt) telepítenek Koszovóba, amely időben képes megfelelő választ adni egy esetlegesen a jövőben kibontakozó hasonló eseménysor idején. A Koszovóban állomásozó NATO-erők jelenlegi létszáma 5600 fö. (NATO KFOR [2012])

A KFOR-erők mandátuma is változott az idők során, a koszovói körülmények változásainak megfelelően, $\mathrm{s}$ egyaránt tartalmazott a klasszikus békefenntartásra jellemző feladatokat, és az azt meghaladó, inkább a békekikényszerítés kategóriájába tartozó funkciókat is (pl. tüzszünet betartatása, UÇK leszerelése). (Friedrich [2005] p. 236.) Az 1244-es BT határozat értelmében eredetileg is széles körben vállalt feladatokat a szervezet, amelyek elsősorban a koszovói biztonságos környezet és a törvényes rend biztosítására, a jugoszláv erők kivonulásának ellenőrzésére, az ellenségeskedések kiújulásának megakadályozására, az UÇK demilitarizálására terjedtek ki, de részüket képezte a nemzetközi területi adminisztráció civil szervezeteinek és a humanitárius segélyszervezeteknek a támogatása és az előbbiekkel

223 A helsinki megállapodás tartalmát a NATO honapján tették közzé az alábbi URL-címen: http://www.nato.int/kosovo/docu/a990618a.htm (letöltés: 2011.12.11.)

${ }^{224}$ Oroszország és a NATO kapcsolatában feszültséget okozott az 1999. május 24-től június 10-ig tartó és a válságot sikeresen lezáró - NATO-bombázás, amelyet a NATO hajtott végre, de BT-felhatalmazás hiányában nemzetközi jogi szempontból illegitim módon, Oroszország kifejezett ellenzése mellett. Az oroszok már 1998 őszén nyilvánvalóvá tették, hogy ha a JSzK elleni katonai intervencióval kapcsolatos BT határozat-tervezetet terjeszt bármely állam a Biztonsági Tanács elé, azt ő meg fogja vétózni. Egyrészt nem értett egyet - saját hasonló problémái miatt. ld. csecsen kérdés és a transzkaukázusi térség - a koszovói albánok szecessziós törekvéseinek bárminemü támogatásával, másrészt pedig kifejezetten nehezményezte, hogy a balkáni térséggel kapcsolatos biztonsági-politikai döntésekben ekkora szerepet kapott a NATO (s Oroszország ily módon kiszorult a koszovói válság kezelésének ezen színteréről). Az ENSZ BT elé nem került az ügy (köszönhetően az oroszok előre bejelentett vétójának), de felhatalmazás hiányában is végrehajtotta a NATO a beavatkozás (légiháborút). Érdekes epizódként az orosz ejtőernyősök egy kis csapata a légitámadások lezárulásakor megjelent a pristinai repülőtéren, ily módon demonstrálva, hogy Oroszországot nem lehet kihagyni a balkáni ügyekből, és később a rendezésből sem. 
való együttmüködés is. Ezeken túl a KFOR számos egyéb területen is tevékenykedett. ${ }^{225}$ (S/RES/1244 [1999])

A KFOR mandátumát többször meghosszabbították - föként a 2004. évi események hatására -, a NATO isztambuli csúcstalálkozóján elismerték, hogy a nemzetközi területi adminisztráció részeként a KFOR térségben maradására továbbra is szükség van, s még ugyanebben az évben, Brüsszelben döntöttek arról, hogy a kontingens a térségben marad. 2005-ben átszervezték a KFOR-t azzal a céllal, hogy gyorsabb, rugalmasabb reagálásra tegyék képessé, így ettől kezdve az egyes egységeknek lehetőségük nyílt szükség esetén más felelősségi körzetekbe is átmenni egy-egy müvelet során, $\mathrm{s}$ mindezzel párhuzamosan a hírszerzési tevékenységüket is hatékonyabbá tették. 2007ben a NATO-vezetők megállapodtak abban, hogy ha Koszovó függetlenedik, akkor is tovább marad a KFOR az országban. 2008-ban újabb reformra került sor, s a KPC (Kosovo Protection Force) erőket fokozatosan leszerelték, s párhuzamosan felállították az annak helyébe lépő KSF-et (Kosovo Security Force), a koszovói entitás tulajdonképpeni „haderejét”. (NATO KFOR [é. n.]) A koszovói biztonsági szervek fejlődésének bemutatására azonban ehelyütt a továbbiakban nem vállalkozunk, a dolgozat a nemzetközi komponensre fókuszál.

\subsection{Demokratikus intézményépítés}

Az EBESZ koszovói müködése meglehetősen régre nyúlik vissza, amennyiben már 1992 őszén hosszút távú misszió települt az akkor még szerbiai tartomány három régiójába: Koszovóba, a Szandzsákba és a Vajdaságba. ${ }^{226}$ A misszió feladata az volt,

\footnotetext{
225 Így segítséget nyújt a koszovói válság idején otthonaikat elhagyni kényszerült vagy kitelepített személyek visszatérésében, az újjápítésben és aknamentesítésben, az egészségügyi ellátás fejlesztésében, a biztonságos környezet és törvényes rend helyreálításában, az etnikai kisebbségek biztonságának megteremtésében, a vallási és történelmi emlékhelyek védelmében, a határörizeti feladatok ellátásában és a fegyvercsempészet visszaszorításában. Részt vesz továbbá a fegyverek, lőszerek és robbanóanyagok megsemmisítési programjában, támogatja a közintézmények létrehozását, a törvényhozói, végrehajtói és igazságszolgáltatási rendszer kiépítését, valamint hozzájárul a politikai, gazdasági és szociális rendszer kiépítéséhez. A KFOR különös hangsúlyt helyez az etnikai kisebbségek védelmére: rendszeresen járőrözik a szerbek és más kisebbségek által lakott területeken (enklávékban) és az ellenőrzőpontok körzetében, szükség esetén kíséretet nyújt az etnikai kisebbségek számára mozgásuk során, biztosítja a vallási és történelmi emlékhelyek védelmét, az élelmiszer-ellátmányok és az oktatáshoz kapcsolódó ellátmányok megfelelő helyre történő eljuttatását. (NATO KFOR [é. n.])

${ }^{226}$ A három régió központjában hozták létre a misszióközpontokat (Pristinában, Novi Pazarban és Szabadkán), de más településeken is létesítettek állandó képviseleteket (pl. Koszovóban a szerbek számára kulturális-történeti szempontból olya fontos Pećben és Prizrenben).
} 
hogy előmozdítsa a párbeszédet a régiók lakossága és a hivatalos szervek között, információt gyüjtsön az emberi jogok és szabadságok megsértésének eseteiről, valamint, hogy elősegítse a problémák megoldását. 1992-ben az EBESZ felfüggesztette a szervezetben Jugoszlávia tagságát háborús politikája miatt, ezért a JSzK nem hosszabbította meg az EBESZ-misszió mandátumáról szóló megállapodást, amelynek így távoznia kellett az országból. (Czapliński [2009] p. 179.)

Az EBESZ következő szerepvállalása a Koszovói Ellenőrző Misszió (Kosovo Verification Mission - KVM) nevü nagyszabású vállalkozás volt, 1998. októberében, amikor is a szervezet missziója azzal a céllal települt Koszovóba, hogy ellenőrizze a Richard Holbrooke és a jugoszláv hatóságok között megkötött megállapodás betartását a koszovói menekültek biztonságos hazatéréséröl és a tartományban állomásozó jugoszláv fegyveres erők létszámának csökkentéséről. Az 1199. sz. BT határozat értelmében az ellenőrző misszió elsődleges feladata volt a tűzszünet ellenőrzése, határrendészeti és rendőrségi tevékenység folytatása, a menekültek visszatérésének segítése és az emberi jogok védelme, de ezen túl folyamatosan tartotta a kapcsolatot az érintett szerb és albán hatóságokkal, felügyelte a választásokat és jelentett illetve ajánlásokat tett az EBESZ-nek és az ENSZ-nek. (S/RES/1199 [1998]) A misszió létszáma elérte az 1500 főt, de 1999. március 20-án az egyre romló biztonsági helyzet miatt kivonult a térségből. A KVM mandátuma hivatalosan 1999. június 8-án szünt meg, három hét előkészítés után (július 1-jén) pedig létrehozták az EBESZ koszovói misszióját (OSCE Mission in Kosovo - OMiK). ${ }^{227}$ (Czapliński [2009] p. 180.) Az OMiK az UNMIK harmadik pilléreként integrálódott az ENSZ polgári igazgatási keretébe, s fö feladata az intézmény- és demokráciaépítés és az emberi jogok védelme lett. A létrehozó dokumentum öt pontban foglalta össze a misszió teendőit:

1. az emberi erőforrások felkészítése (koszovói rendőrség kiképzése, a bírósági személyzet és a köztisztviselők képzése és továbbképzése), mely tevékenységet az EBESZ az Európa Tanáccsal együttmüködve végzi;

2. a demokratizálás és a demokratikus kormányzás elősegítése (civil társadalom, nem-kormányzati szervezetek, politikai pártok és a helyi média fejlesztése);

${ }^{227}$ Az EBESZ Állandó Tanácsa 305. sz. határozatával szüntette meg a - KVM megszüntetése és az OMiK létrehozása között eltelt időszakban előkészítő tevékenységet folytató - rövidéletủ missziót (OSCE Task Force for Kosovo). 
3. a választások megszervezése és lebonyolításuk felügyelete;

4. az emberi jogok védelmének előmozdítása, és érvényesülésük ellenőrzése (a koszovói ombudsman intézményének létrehozása, ezt a feladatot az EBESZ az ENSZ Emberi Jogi Főbiztosával [UNHCHR] együttmüködve valósítja meg)

5. további feladatok ellátása, amelyeket az ENSZ Főtitkára vagy Különleges Képviselője az EBESZ Állandó Tanácsának beleegyezésével ruház a misszióra. (PC.DEC/305 [1999]) (Blockmans [2007] p. 98.)

Az EBESZ tehát nem egyedül tevékenykedik a demokratikus intézményépítés területén, hanem az ENSZ-biztosította kereteken belül végzi munkáját, ám mindegyik területen együtt kell müködnie és konzultálnia kell az adott kérdésben még illetékes egyéb intézményekkel is (elkerülve így a párhuzamosságokat). Ami az elszámoltathatóságot illeti, az EBESZ misszióvezetője - aki egyben az SRSG egyik helyettese is egyben, s akit az EBESZ soros elnöke nevez ki - beszámolási kötelezettséggel tartozik a soros elnök és az EBESZ Állandó Tanácsa felé is. (Halász [2005/b])

Az EBESZ egyik fó tevékenysége - hasonlóan Boszniához - itt is a választások felügyelete, ezért a terület egyértelmüen az OMiK-portfólió része, amiért az EBESZmisszió közvetlen felelösséggel tartozik. A választások során szintén hasznosította szervezet - és a nemzetközi igazgatási struktúra - a boszniai tapasztalatokat amennyiben nem követték el még egyszer azt a hibát, hogy túlzottan korai időpontra időzítették az első választást. A helyi körülmények komplexitása nem elsősorban a terület etnikai összetételéből adódott - itt ugyanis a lakosság túlnyomó része az albán etnikumhoz tartozik, az etnikai arányosság követelményét itt nem kellett úgy érvényre juttatni, mint Boszniában. Külön problémát jelentett azonban az, hogy a terület státusza a 2008-ig terjedő vizsgált időszakban mindvégig bizonytalan volt, s minden, a terület önkormányzásának erősítését célzó döntést regionális összefüggésben, elsősorban a Szerbiával való viszony tükrében kellett kellö érzékenységgel kezelni.

A demokratizálódás területén a választások ellenőrzésén túl az EBESZ számos, a helyi kapacitásépítést előmozdító, a koordinációt fokozó erőfeszítést tesz nemcsak a központi intézmények szintjén, hanem az önkormányzatoknak is segítve az alábbi területeken: jó kormányzás (good governance); emberi jogok; esélyegyenlőség és egyenlő bánásmód; 
kisebbségek védelme és érdekérvényesítésük (különös tekintettel a nem szerb népcsoportok tagjaira: romák, askálik, egyiptomiak, gorániak stb.). Az EBESZ szakértői fontos szerepet játszanak a jogfejlesztés, a jogérvényesítés és az igazságszolgáltatás megreformálása ${ }^{228}$ területén; részt vesznek a pártatlan és multietnikus koszovói rendőrség fejlesztésében.

A választások megszervezése tehát Koszovóban is - hasonlóan Boszniához - a nemzetközi szervezetek közül az EBESZ „portfóliójának” része volt. Koszovó esetében sem tekintjük át az összes eddig lezajlott választást, csupán az első, helyhatósági választással foglalkozunk. ${ }^{229}$

Az EBESZ a választások időpontjának és sorrendiségének megjelölésénél igyekezett a korábbi (pl. boszniai) igazgatási tapasztalatokat hasznosítani, ezért úgy döntött, hogy a helyhatósági szintü választásokat rendezi meg elsőként. Az elhatározást elsősorban az a félelem táplálta, hogy a nemzetközi közösség kifejezetten tartott attól, hogy az „országos” szintű választások kiírása esetén túlzottan elötérbe kerülne a státuszkérdés rendezetlensége, s ez felszítaná a feszültségeket. Az előzetes várakozások azonban sajnos nem teljesültek: nem sikerült az égető kérdésekről elterelni a figyelmet a kampányidőszakban, s a szerbek végül bojkottálták a 2000-es helyhatósági választásokat. A választások időpontjának megválasztása is az óvatosságot tükrözi: Koszovó esetében igyekeztek nem elsietni az első választások kiírását (mint ahogyan ez Boszniában történt), s azzal, hogy több mint egy évet vártak az első választásokkal, az UÇK keményvonalas nacionalista utódpártjainak gyengítését kívánták elérni. A nemzetközi közösség gondosan mérlegelte a választási rendszer kiválasztásakor a lehetséges opciók előnyeit és hátrányait, s itt számolnia kellett a vezető koszovói politikai erők szembenállásával is. ${ }^{230} \mathrm{~A}$ választás végül az arányos képviseleti modellre

\footnotetext{
228 A szakmai tanácsadáson kívül támogatja és ellenőrzi a koszovói jogi és igazságszolgáltatási reformfolyamatban közremüködő kulcsfontosságú intézményeket: a Központi Választási Bizottságot (Central Election Commission), az ombudsman intézményét (Ombudsperson Institution), a Koszovói Igazságszolgáltatási Intézetet (Kosovo Judicial Institute), a Koszovói Jogi Központot (Kosovo Law Center), a koszovói televíziót (Radio Television Kosovo), a koszovói médiaintézetet (Kosovo Media Institute) és a koszovói rendőriskolát (Kosovo Police Service School). (Czapliński [2009] p. 181.)

${ }_{229}$ Koszovóban 2000-ben, 2002-ben, 2004-ben, 2007-ben és 2009-ben tartottak önkormányzati választásokat, parlamenti választásokra pedig a következő években került sor: 2001, 2004, 2007, 2010. (EBESZ Koszovói Misszió [é. n.]) (Koszovó Központi Választási Bizottsága [é. n.])

${ }^{230}$ A pártok nagy része egyetértett az arányos képviseleti modellel, kivéve a két nagy pártot, az LDK-t és a PDK-t. Előbbi az arányos és többségi elemeket egyaránt ötvöző vegyes modellt szeretett volna elfogadtatni, utóbbi pedig a tisztán többségi modellt preferálta. A végső szó a választási modell
} 
esett, egyrészt mert úgy vélték, hogy ez alkalmasabb a kisebb pártok politikai képviselethez juttatására - ez pedig a multietnikus Koszovó ideájával és a kisebbségek védelmével összecsengett -, másrészt pedig a többségi rendszer a választókerületek gyors kialakítását igényelte volna, ez pedig hiteles népszámlálási adatok hiányában nehézkes és megkérdőjelezhető lett volna. (Tansey [2009] pp. 130-132.)

A helyzet különlegessége itt abban ált, hogy a többségi lakosságot kitevő albán etnikum tagjai a nyolcvanas évek legvége óta - amióta a tartomány minden autonóm kiváltságát visszavonták - gyakorlatilag ki voltak zárva a politikai folyamatokból, ráadásul az albánokat elbocsátották az állami intézményekből is. Éppen ezért az államigazgatási struktúra demokratikus múködéséhez mind a tapasztalat, mint pedig a munkaerő nagyrészt hiányzott (mind központi, mind helyi szinten), de a politikai részvételi jogok gyakorlása területén sem álltak rendelkezésre tapasztalatok. A választásokra éppen ezért nagy hangsúly helyezödött, s különösen fontos volt annak a politikai kultúrának a meggyökereztetése, ahol mindennapos elvárás az egyenlöség, a transzparencia érvényesülése és az emberi jogok tiszteletben tartása, vagy éppen a független média. (Everts [2001] p. 246.)

Külön problémát jelentett az egészséges pártstruktúra kialakítása is. A válság nyomán a politikai paletta csupán néhány szereplős volt: vagyis a kilencvenes évek során - az elnyomás alatt, majd a háború idején - végig vezető szerepet játszó mérsékelt Koszovói Demokratikus Liga (Lidhja Demokratike e Kosovës - LDK) volt jelen, rajta kívül pedig azok az erők, amelyek a fegyveres válság idején harcoló albánok legfőbb ernyőszervezetéből, az UÇK-ból igyekeztek politikai mozgalommá transzformálódni. A korábbi katonai alakulatok tagjainak megjelenése a politikai életben nagy kihívás elé állította az EBESZ-t. A 2000-es helyhatósági választások bejelentésére hirtelen megszaporodtak a választáson indulni kívánó politikai szervezetek, s hamarosan látszott, hogy három pártnak van esélye nagy támogatást szerezni a választók körében: a már említett LDK-nak, és az UÇK-ból „kinőtt” két formációnak, a Koszovói Demokrata Pártnak (Partia Demokratike e Kosovës - PDK) és a Szövetség Koszovó Jövőjéért mozgalomnak (Aleanca për Ardhmërinë e Kosovës - AAK). A pártok nehéz helyzetben voltak, mert meg kellett teremteniük politikai arculatukat az ehhez kapcsolódó 
programjukkal együtt. Ekkorra ugyanis a korábbi örökségek már nem bizonyultak elegendőnek: az LDK esetében túl kellett lépni a nehéz időkben jellemző hősies kitartás és a párhuzamos állam kiépítésének mítoszán, az UÇK-ból alakult pártok pedig többen voltak, nem hivatkozhatott mindenki csupán a háborús hőstettekre, ennél kreatívabbnak kellett lenni. Az EBESZ ezen körülmények között két dologra fókuszált: egyrészt létrehozta Koszovó-szerte a politikai pártok szolgáltató központjainak (Political Parties Service Centers - PPSCs) hálózatát, ahol tréningeket szerveztek, valamint logisztikai és egyéb segítséget nyújtottak a politikai mozgalmaknak, valamint biztosították a pártok közti folyamatos párbeszédet kerekasztal-találkozóikon. Emellett létrehozták a politikai pártok számára egy konzultatív fórumot is (Political Parties Consultative Forum PPSF), ahol pedig a pártok a központi Választási Bizottsággal és UNMIK-kal tarthattak kapcsolatot. A másik, amihez az EBESZ ragaszkodott, hogy a választások eredményének ismeretében haladéktalanul álljanak fel a helyi önkormányzatok és kezdjék meg müködésüket. ${ }^{231}$ Az első választások 2000-ben rendben zajlottak, annak ellenére, hogy a szerbek bojkottálták, de mindenképpen fontos eredmény volt, hogy a politikai pártok megismerhették valódi társadalmi támogatottságukat, s folytatódhatott a politikai kultúra további fejlődési folyamata is. (Oliva [2007])

A 2008-as események - Koszovó függetlenségének egyoldalú deklarálása következtében változott az EBESZ-misszió müködési környezete is. A missziónak egyrészt ezzel kellett szembenéznie, másrészt a csökkentő nemzetközi részvételi hajlandósággal, amely az EBESZ-kontingens létszámának és költségvetésének megkurtításának következményével járt. Át kellett gondolnia a szervezetnek a mandátumát is, az azonban világos volt, hogy az emberi jogok védelme és a koszovói jelenlét meg kell, hogy maradjon prioritásként, a szervezetnek továbbra is szorosan együtt kell müködnie a nemzetközi igazgatás egyéb szerveivel (most már elsősorban az EULEX-szel), s továbbra is részt kell vennie a koszovói kapacitásépítési folyamatban képzéseivel és tanácsadó tevékenységével, különös tekintettel a Központi Választási Bizottság Munkájára. (Czapliński [2009] p. 189.)

${ }^{231}$ Ezt azért tartotta szükségesnek az EBESZ, mert Boszniában komoly problémát okozott, hogy a választások után a megválasztott testületek sokszor csak nagy nehézségek árán tudták (vagy akarták) megkezdeni a munkát. Az is igaz persze, hogy a politikai szcénát Koszovóban korántsem bénították a politikai szereplők obstrukciós szándékai úgy, mint ahogyan az Boszniában jellemző. 


\section{KONKLÚZIÓ}

A dolgozat során bemutattuk a nemzetközi területi igazgatás történelmi példáit, $\mathrm{s}$ megvizsgáltuk részletesebben a boszniai és a koszovói modelleket. Ezután megállapíthatjuk, hogy az első hipotézisünk igaznak bizonyult.

A balkáni térség Bosznia-Hercegovinában és Koszovóban müködö nemzetközi adminisztrációs modelljei valóban nem rendelkeznek a korábbi vagy párhuzamosan müködö igazgatási példákhoz képest lényegesen eltérö tulajdonságokkal, s nem állithatjuk egyikröl sem, hogy a nemzetközi területi adminisztráció egy „újabb generációját” képviselnék.

Koszovó esetében az a tény, hogy az igazgatási funkciók mindegyikét átvette egy átmeneti időszakra a nemzetközi adminisztráció, nem jelenti azt, hogy ez más modelleknél nem történt így. Már az egészen korai példáknál, például a Saar-vidék esetében is jellemző volt, hogy egy nemzetközi szervezet - akkor a Nemzetek Szövetsége - vállalta fel a terület teljes és közvetlen igazgatását. Bosznia esetében semmiképpen nem beszélhetünk ,új generációról”, mert ha a nemzetközi jelenlét igazgatási jogosítványainak körét nézzük, akkor az sokkal kiterjedtebb más modelleknél (pl. a kelet-timori esetnél, ahol a teljes államigazgatás azért omlott össze, mert 8000 közalkalmazott és köztisztviselő egyszerre távozott az országból annak függetlenedésekor, vagy másik példaként említhetnénk Koszovót is). Bosznia annyiban viszont valóban különleges, hogy általában nem jellemző, hogy az igazgatási jogkörök tekintetében az idő előrehaladásával a nemzetközi komponens erősödik, a helyi pedig gyengül. A bevett séma az, hogy a nemzetközi szint jogosítványai delegálódnak fokozatosan a helyi szintre, Boszniánál pedig épp ellenkezőleg: az OHR jogait a bonni döntés értelmében addig nem tapasztalt mértékben megnövelték.

Az ún. „generációs vitára” reflektálva (vagyis: léteznek-e a nemzetközi területi adminisztrációnak generációi, hasonlóan a békefenntartáshoz) még egy adalékként érdemes megjegyezni, hogy ennek az evolutív szemléletnek az elfogadásával valójában azt állítanánk, hogy a fejlődés egyirányú, s csak elöre mutathat, holott sokkal 
lényegesebb, hogy az igazgatási modelleknek mindig alkalmazkodniuk kell a helyi viszonyokhoz - a hatékonyság záloga tehát ez, és nem bizonyos bevett sémák alkalmazása.

A második feltevésünket is igazolhatjuk:

A két vizsgált nemzetközi igazgatási modell egymással történö összehasonlitása nyomán megállapitható, hogy a nemzetközi közösség a koszovói nemzetközi területi igazgatás felállítása során mind a strukturális jellemzöket tekintve, mind pedig müködését illetöen hasznositotta más (elsösorban a boszniai) modellek tapasztalatait. A nemzetközi területi adminisztrációt jellemzi tehát a szervezeti tanulás képessége, ${ }^{232}$ de csak olyan mértékben, amennyire az összeegyeztethetö azon nemzetközi szereplök érdekeivel, amelyektöl a mandátum származik.

A nemzetközi területi adminisztráció koszovói modellje több ponton hasznosította a korábbi, fóként boszniai igazgatási tapasztalatokat, ezt néhány esettel az alábbiakban igazoljuk is. Fontos felismerés volt például a koszovói nemzetközi igazgatás felállításánál, hogy a párhuzamosságok elkerülése érdekében az ENSZ irányítása alá tartozó pilléres rendszert hoztak létre, s így a részt vevő szervezeteknek ugyan meglehetősen nagyfokú önállóságot hagyva, de mégis az intézményesített konzultációskooperációs kényszer mentén arra késztették őket, hogy a hasonló területen müködő más intézményekkel koordinálják erőfeszítéseiket.

Természetesen az együttmüködés nem volt mindig zökkenőmentes, és sokszor a nézeteltérések a két érintett intézmény eltérő szervezeti struktúrájából vagy működési elveiből adódtak. Problémát okozott például Bosznia esetében, amikor a szervezett bünözéssel szembeni harcot mandátuma részének tekintette mind a nemzetközi rendőri (EUPM), mind pedig a nemzetközi katonai erő (IFOR). Boszniában a nemzetközi jelenlét katonai és civil komponense egymástól függetlenül müködik, s nyilván elvárt az egymással való egyeztetés, de ez mégsem müködött mindig megfelelően a valóságban. A koordinációs kényszer hiánya miatt a két szervezet sem egyeztetett megfelelő mértékben, így ebben az időben - jogosan - sok kritika érte a működés ezen területét.

232 Természetesen nem szervezetelméleti megközelítést alkalmaz a dolgozat, a kifejezést csak kölcsönvettük. 
Szintén két szervezet között okozott némi fennakadást és újfent Boszniában, hogy a választások koordinálásában és szabályozó környezetének megteremtésében az EBESZ inkább preferálta volna az alulról építkező, a konzultáción és kooperáción alapuló megoldást a vitás kérdésekben, az OHR viszont hajlamos volt kiterjedt bonni jogosítványaival élni, s egy újabb rendelet megalkotásával és az új jogszabály kikényszerítésével gyorsan és hatékonyan megoldani a helyzetet (sokszor tekintet nélkül az érintettek reakcióira).

$\mathrm{Az}$ is egy tanulási folyamat eredményének tekinthető, hogy Koszovóban az első választásokat csak megfelelő előkészítést követően, s alacsonyabb, helyhatósági szinten tartották meg. Boszniában az igazgatási misszió sikertelenségének egyik oka éppen a választások kapcsán a nemzetközi igazgatás nem kellően körültekintő hozzáállása volt. Általános választást tartani alig tíz hónappal a háború lezárását követően egy etnikai törésvonalak mentén súlyosan megosztott országban - nos, ennek az lett a következménye, hogy a nemzetközi igazgatás hozzájárult, hogy a lehető legdemokratikusabb úton (választások nyomán) a háborús nacionalista erők kezébe jutott a hatalom. Mi történt valójában? A bizonytalan szavazópolgárok nem bízhattak hiteles, nem etnikai alapon politizáló jelöltekben, hiszen ennyi idő alatt, ha formálódtak is ilyen erők, azok nem erősödtek még meg annyira, hogy egy választáson eséllyel szálljanak ringbe. Az is nyilvánvaló volt, hogy ennyi idővel a háború vége után a hatalom (politikai, gazdasági stb.) túlnyomórészt még mindig a válság idején is főszerepet játszó nacionalista erők kezében van, ráadásul érzékelhető volt a nemzetközi közösség azon szándéka is, hogy a Boszniából történő kivonulást fontolgatják (ergo a nemzetközi jelenléttel nem kívánják tovább garantálni a boszniai békét). Ebben a helyzetben a legkisebb rosszat választották a boszniai szavazók, és azokat erősítették meg hatalmukban, akik a háború alatt is védelmet tudtak nyújtani számukra: a nacionalista erőket. Koszovóban ugyan a kiinduló helyzet is más volt (az etnikai megosztottság is más jellegü volt, mint Boszniában), de a választásoknál kifejezetten körültekintően jártak el, okulva a boszniai tapasztalatokból.

A továbbiakban elsőként összehasonlítjuk a boszniai és a koszovói területi igazgatást, ezután bemutatjuk legfőbb jellemzőiket és tapasztalataikat, végül pedig kitérünk a nem modellspecifikus, általános tanulságokra. 
A boszniai és koszovói területi igazgatási modellek összevetése során a kettő között több lényeges különbség fedezhető fel, ezeknek természetesen csak egy része indokolható a második tézisünkkel - miszerint a nemzetközi közösség az igazgatási modellek felállítása során tanul korábbi tapasztalataiból -, nagyrészt a helyi viszonyok és környezet sajátosságaiból fakadnak az eltérő és hasonló jellemzők. Mindkét modellnél elválasztható egymástól a nemzetközi polgári és katonai jelenlét, de Koszovóban a polgári igazgatás minden résztvevő intézménye egy, az ENSZ által felügyelt struktúrába, az UNMIK-ba integrálódott, amelynek feladata, hogy a résztvevők munkáját koordinálja. Boszniában nem jellemző ez a fajta együttmüködés, ennek eredményeként meglehetősen sok átfedés, párhuzamosság volt tapasztalható a nemzetközi igazgatás müködésében. Mindkét modellben egy személy áll a polgári igazgatási komponens élén, Boszniában az OHR, Koszovóban pedig az SRSG, a különbség köztük abban áll, hogy míg az SRSG mindvégig az ENSZ-et képviselte, az OHR, ezen túlmutatóan, az egész nemzetközi közösséget (vagy ha úgy tetszik, a nemzetközi közösség összes Boszniában tevékenykedö szereplöjét), mandátumukat azonban mindketten az ENSZ-től kapták. Boszniában az OHR mellett müködik egy kvázi-felügyeleti szerv, ez a Békevégrehajtó Tanács (PIC), Koszovóban ez az intézmény hiányzik, ennek nyilván az előző mondatban már említett jelenség az oka: az OHR sok nemzetközi szereplőnek tartozik beszámolási kötelezettséggel (ezeket képviseli a PIC), míg az SRSG csak az ENSZ-nek.

A boszniai területi igazgatás bemutatásánál a dolgozat második részében nagy hangsúlyt helyeztünk a boszniai állam felépítésének és müködésének bemutatására (ezt így Koszovónál külön nem tettük meg, ott csupán a legszükségesebb mértékben utaltunk a helyi intézményekre). Erre azért volt szükség, mert a sajátos boszniai államszervezet olyan közeget biztosít a nemzetközi adminisztrációnak, ami kiegészülve a nemzetközi közösség által követett és alkalmazott normarendszer elemeivel, együttesen olyan helyzetet eredményezett, amelyben nem müködhet hatékonyan a nemzetközi területi adminisztráció. Boszniában a nemzetközi területi igazgatás mindvégig a kezdettől fogva létező helyi demokratikus intézményekkel kellett, hogy együttmüködjön, itt nem fordult elö, hogy a hatalmi ágak bármely szegmentumában a nemzetközi elem a helyi nélkül lett volna jelen. Éppen ezért fontos volt részletesen kitérni a boszniai központi intézmények bemutatására, $\mathrm{s}$ jelezni, hogy a nemzetközi jelenlét mennyiben befolyásolta ezek müködését. Koszovóban az államhatalmat és a kormányzati 
funkciókat megtestesítő szervek csak fokoztaosan jelentek meg, s mintegy nullaösszegü játszmaként, a phasing in - phasing out logikája mentén fokozatosan valósult meg az ún. local ownership, vagyis váltak a nemzetközi irányítás alatt álló intézmények helyiekké.

Bosznia esetében az egyik legjelentősebb problémát az etnikai egyensúly modelljén alapuló államszervezés jelenti. Ez megmutatkozik egyrészt az állam etnoterriorialista elveken való tagolásában, másrészt pedig a közintézményekben alkalmazott etnikai balansz elvében. A választás, hogy a liberális demokráciákra általában jellemző többségi elv helyett az etnikai egyensúly-modellt alkalmazzák, érthetö, hiszen egy etnikailag súlyosan megosztott, $\mathrm{s}$ a háborúból éppen kilábaló társadalomban ez megfelelő módszer lehet, hogy az államalkotó közösségek együttélési hajlandóságát fokozza. A valóságban azonban a modell nem teljesíti Boszniában a létrehozásakor kitüzött célokat, s elméletileg ugyan igazságos, a gyakorlatban viszont olyan merev, alkotmányban rögzített struktúrát eredményez, amely müködésképtelen. A modell következménye ugyanis, hogy a központi állam gyenge, s a decentralizáció magas foka miatt a legtöbb hatalmi jogosítvány az államigazgatás alsóbb szintjeire - Boszniában az entitásokhoz, a kantonokhoz és az önkormányzatokhoz - van telepítve, az egyes etnikumok viszont a döntéshozatalban vétójoggal rendelkeznek. Számos lehetőség kínálkozik így az obstrukcióra, amivel a boszniai politikai szereplök gyakran élnek is. Így olyan - nemcsak a sikeres tranzíció lebonyolításához szükséges, ${ }^{233}$ hanem az Európai Unóhoz való közeledés szempontjából is fontos - területeken hosszú évek óta nem sikerült elörelépni, mint pl. az alkotmányozási folyamat.

A balkáni nemzetközi területi igazgatásokat a dolgozat második és harmadik részében abból a szempontból is megvizsgáltuk, hogy a nemzetközi szervezetek közti munkamegosztás a vizsgált dimenziók alapján hogyan alakul. Megállapíthattuk, hogy a térség stabilizálása, a biztonságos viszonyok megteremtése három nagy nemzetközi szervezet felelősségi körébe tartozik, ezek az Egyesült Nemzetek Szervezete, az Észak-

\footnotetext{
${ }^{233}$ A délszláv államok esetében nem szabad megfeledkeznünk arról a fontos tényröl, hogy a háborúkban érintett államoknak nemcsak a fegyveres harcok súlyos infrastrukturális, és a fejlődést minden területen visszavető következményeivel kell számolniuk, de a kilencvenes években a függetlenedő államoknak - a háborútól függetlenül és a közép-európai államokhoz hasonlóan - egyébként is le kellett volna vezényelniük az átmenetet a demokratikus piacgazdaságok kialakítása során. A tranzíciós folyamat természetesen nemcsak, hogy később indulhatott meg a háború miatt, de jóval alacsonyabb fejlettségi szintről is indultak a térség országai.
} 
atlanti Szerződés Szervezete és az Európai Unió. A boszniai nemzetközi jelenlét polgári aspektusához tartoznak a belső biztonságot, a közrendet szavatoló nemzetközi rendőri erők, a nemzetközi részvételt tekintve itt elsőként az ENSZ irányítása alatt álló UNMiBH keretében müködtetett rendőri erőt, az IPTF-et kel megemlítenünk, amely mandátuma lejártáig, 2002-ig (az UNMiBH megszünéséig) tartózkodott BoszniaHercegovinában. Még ebben az évben az IPTF-et az EU rendőri missziója, az EUPM váltotta, ez 2012 nyaráig látott el hasonló feladatokat, mint elődje, vagyis elsősorban a boszniai rendőrség demokratikus átalakítási folyamatát felügyelte, mindenekelőtt a tapasztalatok átadása útján. A nemzetközi rendőri szervek egyike sem rendelkezett direkt végrehajtó jogosítványokkal, feladatuk a tanácsadás, képzés és monitoring, valamint a rendőrségi reform és a szervezett bünözés elleni küzdelem előmozdítása volt. A nemzetközi igazgatás biztonsági (katonai) aspektusának részei voltak az egymást követő nemzetközi békefenntartó erők, amelyek mindegyike az ENSZ BT-nek az ENSZ Alapokmány VII. fejezete alapján adott felhatalmazásával rendelkezett. Az első két misszió a NATO irányítása alá tartozott (1995-1996-ban az IFOR, majd 1996-2004-be az SFOR), a harmadik, azóta is müködő katonai kontingenst, az EUFOR-t viszont az EU jegyzi. A katonai és a rendőri missziók közül a katonai tekinthető sikeresebbnek, hiszen a világosan meghatározott, egyébként meglehetősen szükre szabott mandátumát (a biztonságos viszonyok megteremtését, a harcok kiújulásának megakadályozását, a civil és humanitárius szervezetek támogatását, valamint a menekültek biztonságos visszatérésének előmozdítását) teljesítette. A rendőri missziónál már több probléma jelentkezett: folyamatos kritikák érték a szervezetet az alulfinanszírozottsággal és a humán állomány felkészületlenségével kapcsolatban, ráadásul a kooperáció hiánya miatt - amint arra már utaltunk - hatásköri vitákba is keveredtek a rendőri és katonai erők annak kapcsán, hogy a szervezett bünözés elleni harcban melyiknek milyen jogai vannak. Látható, hogy az az átrendeződés, ami az EU szerepvállalásának növekedését jelentette, mind a nemzetközi katonai, mind a polgári biztonsági erök esetében lezajlott: a nemzetközi katonai erő biztosítását 2004-ben a NATO-tól, a nemzetközi rendőri feladatok ellátását pedig 2004-ben az ENSZ-től vette át az Európai Unió. Koszovóban kezdettől fogva az ENSZ BT felhatalmazásával rendelkező, NATO-irányítás alatt álló békefenntartók alkotják a nemzetközi jelenlét katonai komponensét, s a nemzetközi rendőrség funkcióit is ellátták egészen 2001-ig, amikor a civil igazgatási keretben, az UNMIK-ban változás történt: ekkor a korábbi első pillér megváltozik, s a menekültek visszatérésének elősegítése helyett feladata a rendőrség és igazságszolgáltatás kiépítése 
lett. Így tehát a rendőrségi feladatok köre ezután már az ENSZ által gondozott első pilléres civil igazgatási feladat lesz, ez azonban nem jelenti azt, hogy rendfenntartó feladatokat nem lát el a KFOR továbbra is.

A második vizsgált dimenzió a demokratikus államépítés volt, ahol számos kormányközi és nem-kormányzati nemzetközi intézmény tevékenykedik, úgymint az EBESZ, ENSZ, és az EU is, de a föszerep az EBESZ-é. A szervezet - mind Boszniában, mind Koszovóban - aktívan részt vett a választások lebonyolításában, fentebb már bemutattunk, hogy a koszovói igazgatás e téren mit hasznosított a boszniai tapasztalatokból.

A harmadik és negyedik dimenzió, amely még vizsgálat tárgyát képezheti, az általam humán és gazdasági dimenziónak nevezett aspektusa a nemzetközi igazgatási struktúráknak. Ezekkel a dolgozatban ugyan nem foglalkozom - ezek a témák további kutatási irányokat jelölhetnek ki -, ehelyütt röviden azonban mégis érdemes szólni ezekről is. A humán aspektus felöleli a következő területeket: emberi jogok védelme, menekültek visszatérése, a háborús bünösök felelösségre vonása. Az első területen (emberi jogok) mind Boszniában, mind Koszovóban nagy hangsúlyt helyeztek a kérdésre már a válság lezárásakor, s létrehozták azokat az intézményeket, amelyek az emberi jogok érvényesülésének legfőbb zálogai, jellemző volt, hogy ezen szervek müködésében a nemzetközi komponens (részvétel) néhány évig legalább biztosítva volt. Különösen nagy jelentősége van az emberi jogok prioritásként való kezelésének ezekben a társadalmakban, ahol a háborúk során súlyos humanitárius jogsértések történtek, s a válság egyik okaként mindig megjelent, hogy elnyomtak egy vagy több kisebbséget. Végsősoron azonban az emberi jogok érvényre jutása kisebb részben függ a nemzetközi szervezetektől és nagyobb részben a helyi társadalomtól és a helyi intézményektől, amelyek a mindennapi élet során bizonyítják ezirányú elkötelezettségüket, vagy éppen cáfolják azt. Az emberi jogvédelem területén a nemzetközi szervezetek közül a legföbb illetékes az EBESZ. A menekültek kérdésével mindkét országban az ENSZ Menekültügyi Főbiztossága (UNHCR) foglalkozik leginkább, de ezen a területen (s az emberi jogok ügyében is) gyakran játszanak aktív szerepet a nem-kormányzati nemzetközi szervezetek. Az ad hoc jellegű hágai Volt Jugoszlávia Nemzetközi Törvényszékkel (ICTY) való együttmüködés minden térségbeli állam kötelessége (amit a rendező dokumentumokban rögzítettek is), hosszú ideig 
azonban alacsony volt a kooperációs készség, különösen a két leginkább érintett állam, Szerbia és Horvátország) esetében. Ez annyiban változott az elmúlt években, hogy a nemzetközi közösség összefogásával gyakoroltak nyomást a két államra, $\mathrm{s}$ nyilvánvalóvá tették: a térség országai nem haladhatnak az olyannyira kívánt euroatlanti integráció irányába, amíg ki nem szolgáltatják legkeresettebb háborús bünöseiket. Az EU azonban sokszor nem következetes a fenyegetései betartását illetően, s többször előfordult már, hogy a feltételként szabott elvárást nem, vagy csak részben teljesítette egy adott állam, az EU pedig mégis megadta a ,jutalmat”. Visszatérve az ICTY-ra, a legkeresettebb bünösök (Milošević, Karadžić, Hadžić) mára már a hágai fogdákban várják ügyükben az ítélethirdetést, a Törvényszék megítélése azonban meglehetősen negatív a balkáni társadalmakban, s ily módon a társadalmi megbékéléshez sem tudott a kívánt mértékben hozzájárulni az intézmény.

A negyedik, vizsgálatra érdemes dimenzió a gazdasági, itt mindkét ország esetében igaz, hogy a gazdasági stabilizációs intézkedések főszereplői az Európai Unió elsősorban, s mellette a jelentősebb nemzetközi pénzügyi intézmények (IMF, Világbank), de az ENSZ család számos szakosított és egyéb intézménye is szerepet vállal a folyamatban. Mind Bosznia, mind pedig Koszovó - a térség többi államához hasonlóan - az Európai Unióban képzeli el a jövőjét, az együttmüködés legfőbb terepe ma az 1999-ben az EU által útjára bocsátott stabilizációs és társulási folyamat (stabilization and association process - SAP). Az európai integrációs elörehaladást tekintve Bosznia az egyik leggyengébben teljesítő állam a Balkánon, s a stabilizációs és társulási megállapodást (stabilization and association agreement - SAA) 2008 júniusában ugyan aláírta, s le is zárult a ratifikációs folyamat 2011 elején, de az EU felfüggesztette a hatályba lépést addig, amíg Bosznia az előírt feltételeket nem teljesíti (alkotmányos reform, népszámlálás, a nem államalkotó kisebbségek képviseletének biztosítása bizonyos állami szervekben). Koszovó előrehaladását pedig az akadályozza, hogy szuverén államként való elismerésének kérdése megosztja nemcsak a nemzetközi, de a szükebben vett európai környezetet is (nem is beszélve a regionálisról), s ez azt eredményezi, hogy amíg az Unió tagállamai nem képviselnek egységes álláspontot Koszovó elismerésének kérdésben, addig nem lehet nemzetközi szerződésen alapuló intézményes kapcsolatot kiépíteni az EU és Koszovó között. 
Végül néhány általános megjegyzéssel zárjuk a konkludáló fejezetet, amely a balkáni példákra is vonatkozik (legalább az egyikre), de van relevanciája általában véve is a nemzetközi területi igazgatásokra.

1. Jól definiált célmeghatározás a nemzetközi igazgatási misszió telepítésekor: nagy gondot okozhat, ha a célt nem, vagy csak homályos és kétértelmű módon határozzák meg, mint pl. Koszovó esetében, amikor a státuszrendezés kapcsán a nemzetközi közösség nem tette nyilvánvalóvá, hogy melyik az általa támogatott végső megoldás. A világos célmeghatározás egy másik szempontból is lényeges: nyugodtabb a társadalomban a közhangulat, ha egyértelmü a vízió. Példaként említhetjük Koszovó esetét, amikor a 2004-es események megmutatták: elég egy kis szikra, hogy a tartományban ismét fellángoljanak és nagyon rövid alatt fegyveres összetűzésekké eszkalálódjanak az etnikai ellentétek. Fontos az is, hogy a célmeghatározás lehetőleg a célállam lakossága nagyobb részének támogatását is élvezze, mert ez nagyban növeli legitimitását.

2. Az átgondolt és reális feltételeket tartalmazó „kiérdemelt szuverenitás” (earned sovereignty) elv következetes alkalmazása: fenti példákban is említettük, hogy a nemzetközi szervezetek gyakran támasztanak feltételeket bizonyos elönyökért cserébe (pl. a teljes szuverenitás megszerzése vagy előrelépés egy nemzetközi szervezet teljes jogú tagsága felé), majd ezek maradéktalan teljesítéséhez nem feltétlenül ragaszkodnak végül. A legtöbb esetben ennek az oka nem az állhatatosság hiánya szokott lenni, hanem az a tény, hogy a nemzetközi szervezet rosszul mérte fel, hogy mit lehet reálisan elvárni az adott országtól. Erre volt jó példa a koszovói státusztárgyalások során alkalmazott standards before status elv, amiről kiderült, hogy a demokratikus kritériumok ideáltipikus gyüjteményét - amit csupán az érett demokráciák némelyike képes teljesíteni - elvárni a koszovói entitástól erős túlzás. A nemzetközi közösség így arra kényszerült, hogy 2005-ben végül felhagyjon az elvvel.

3. Elszámoltathatóság: meg kell teremteni a nemzetközi területi igazgatás célállamban tevékenykedő intézményeinek és alkalmazottainak elszámoltathatóságát. Ez nem csupán azért lényeges, mert demokratikus deficitet eredményez, ha ez a demokráciákban alapvető kritérium nem teljesül, de felveti a hatalmi ágak szétválasztása klasszikus elvének semmibe vételét is, amennyiben a végrehajtó hatalomnak nem kell felelnie 
tetteiért bírói fórumok előtt. Egyben rossz üzenetet is közvetít a célállam lakossága felé, miszerint a nemzetközi igazgatás elvárja a demokrácia szabályainak betartását a helyi lakosságtól, de magára nézve nem tartja ezeket kötelezőnek.

4. Ne legyen túlságosan erös a nemzetközi függés: ha ez így van, akkor nem alakul ki és szilárdul meg a felelősségteljes politizálás légköre, s a helyi politikai vezetök gyakorlatilag tét nélkül használhatnak demagóg-populista politikai retorikát népszerüségük növelése érdekében, anélkül, hogy a következményeket viselniük kellene. Ezzel összefüggésben érdemes utalnunk a concept of ownership-re, ami kb. a „tulajdonlás koncepciója”, s lényege, hogy a nemzetközi területi adminisztrációk és a helyi szereplők megosztják a hatalmat és azzal együtt a felelősséget is, s a nemzetközi igazgatási modellek ideiglenes jellegéből fakadóan mind több lesz a „saját tulajdon” aránya, mind kevesebb a „nemzetközi”, ami végső soron idővel a szuverenitás teljes (vissza)delegálását jelenti a helyieknek.

5. A belátás képessége: ezt az elvet egyaránt vonatkoztathatjuk a nemzetközi területi adminisztráció mögött álló nemzetközi közösségre (vagy annak bizonyos tagjaira), de a helyiekre is. Utóbbiakra annyiban, hogy hasznos lenne észrevenni a patthelyzeteket, amikor már mindenki nullaösszegü játszmaként kezel bizonyos helyzeteket, s kivárásra rendezkedik be. Nem minden esetben fognak úgy alakulni az események ugyanis, mint ahogyan az Koszovó esetében a függetlenség kivívása után történt. Másrészről hasznos tanács lehet a nemzetközi területi adminisztrációkra vonatkozóan is, melyek müködtetése során a nemzetközi közösség általában a létrehozáskor lefekteti azokat az elveket, amelyeket fontosnak vél az adott rendezés szempontjából. Az általános gyakorlat az, hogy ezen a normatív kereten nem - vagy csak nagyon nehezen - változtat később a nemzetközi közösség akkor sem, ha a körülmények megváltoznak, vagy kiderül, hogy eleve elhibázott a koncepció. A balkáni igazgatási modellek esetében is sok ilyen elv van, amelyek közt kogens normákat is találunk szép számmal, de ehelyütt csak hármat emelünk ki: a határok sérthetetlenségének elve; az egyes államrészek kiszakadásának tilalma; a szuverenitás és területi integritás védelme. A három, egyébként egymással nyilvánvalóan összefüggő - lényegében a szuverenitás és annak társnormáiként megjelenő - elv kiegészülve a belső, az állam hatékony működését gátló tényezőkkel, olyan gúzsba köti a boszniai rendezési folyamatot, amiből egyelőre nem látni, hogy tud majd kiszabadulni. A nemzetközi közösség a precedenstől fél, s attól, 
hogy a hasonló helyzetben levő, szecessziós törekvésekkel bíró területek Koszovóhoz hasonló megoldást választanak, és - élve a népek önrendelkezési jogával - kiszakadnak abból az államból, amelyhez addig tartoztak. Ezzel pedig veszélyeztetik a nemzetközi békét és biztonságot, háborús gócpontok lesznek, és újabb feladatokat rónak majd az ENSZ-re és a nemzetközi közösség egyéb tagjaira. Az ténykérdés, hogy Koszovó 2008. február 17-én kikiáltotta függetlenségét; $\mathrm{s}$ ha nemzetközi fórumokon magasrangú diplomaták és politikusok ki is jelentik róla, hogy ez nem precedens, attól még természetesen az.

„Ez nem a vége. Még csak nem is a vég kezdete. De talán a kezdet vége.”234

${ }^{234}$ This is not the end. It is not even the beginning of the end. But it is, perhaps, the end of the beginning. (Winston Churchill, 1942) 


\section{HIVATKOZÁSOK JEGYZÉKE}

\section{Könyvek, folyóiratcikkek, tanulmányok}

AfSAH, Ebrahim - Guhr, Alexandra H. [2005]: Afghanistan: Building a Stet to Keep the Peace. In: von Bogdandy, Armin - Wolfrum, Rüdiger (szerk.): Max Planck Yearbook of United Nations Law. 9. évf., Martinus Nijhoff Publishers, Leiden, pp. 373-456.

BArfiEld, Thomas [2010]: Afghanistan. A Cultural and Political History. Princeton Univeristy Press, Princeton \& Oxford.

BELLONI, Roberto [2007]: State Building and International Intervention is Bosnia. Routledge, New York - London

BELLONI, Roberto [2009]: Bosnia: Dayton is Dead! Long Live Dayton! Nationalism and Ethnic Politics, 15. évf., pp. 355-375.

Benson, Leslie [2004]: Yugoslavia. A Concise History. Palgrave Macmillan

BenZING, Markus [2005]: Midwifing a New State: The United Nations in East Timor. In: von Bogdandy, Armin - Wolfrum, Rüdiger (szerk.): Max Planck Yearbook of United Nations Law. 9. évf., Martinus Nijhoff Publishers, Leiden, pp. 295-372.

BERTA Zsolt [2001]. A választási formulák. ELTE OTDK dolgozat. Forrás: http://www.ajk.elte.hu/file/BertaZsolt-ValasztasiFormulak.pdf (letöltés: 2012.08.02.)

BerTIN, Thomas [2008]: The EU Military Operation in Bosnia. In: Merlingen, Michael - Ostrauskaité, Rasa (szerk.): European Security and Defence Policy. An Implementation Perspective. Routledge, London, pp. 61-77.

BIEBER, Florian [2006]: Bosnia-Herzegovina: Slow progress towards a Functional State. Southeast European and Black Sea Studies, 6. évf., 1. sz., pp. 43-64.

BIEBER, Florian et al. [2009]: Understanding the War in Kosovo. Routledge, London

BíRÓ László [é. n.]: Bosznia-Hercegovina a daytoni szerződéstől a stabilizációs megállapodásig. Forrás:

http://www.balkancenter.hu/pdf/biro_balkanmint01.pdf (letöltés: 2010.07.23.)

Blockmans, Steven [2007]: Tough Love: The European Union's Relations with the Western Balkans. Doktori értekezés, Universitet Leiden Forrás: https://openaccess.leidenuniv.nl/bitstream/handle/1887/12390/Thesis.pdf?se quence $=4$ (letöltés: 2012.03.28.)

CAMPBELL, Gregory F. (1970): The Struggle for Upper Silesia, 1919-1922. The Journal of Modern History, 42. évf., 3. sz., pp. 361-385. 
CAPLAN, Richard [2005]: International Governance of Warn-Torn Territories. Rule and Reconstruction. Oxford University Press, Oxford

Chandler, David [2000]: Bosnia. Faking Democracy after Dayton. Pluto Press, London - Sterling, Virgina

Chesterman, Simon [2004]. You, the People. The United Nations, Transitional Administration, and State-Building. Oxford University Press, Oxford

CHURCHILL, Winston S. [1999]: A második világháború / 1. Európa Könyvkiadó, Budapest

CHOPRA, Jarat [1999]: Peace Maintenance: The Evolution of International Political Authority. Routledge, London

ChOpRA, Jarat [2000]: The UN's Kingdom in East Timor. Survival, 42. évf., 3. sz., pp. $27-40$.

CONFLiCt BAROMETER [2008]. Crises Wars - Coup d'État - Negotiations - Mediations - Peace Settlements. 17th Annual Conflict Analysis. Heidelberg Institute for International Conflict Research at the Department of Political Science, Univerity of Heidelberg. Forrás:

http://www.hiik.de/en/konfliktbarometer/pdf/ConflictBarometer_2008.pdf (letöltés: 2011.05.29.)

CsICSMANN László [2006]: Iszlám és demokrácia a Közel-Keleten és Észak-Afrikában. A nyugati típusú demokrácia adaptálásának lehetőségei és korlátai a tágabb értelemben vett Közel-Keleten. Ph.D. értekezés, Budapesti Corvinus Egyetem, Nemzetközi Kapcsolatok Multidiszciplináris Doktori Iskola. Forrás: http://phd.lib.uni-corvinus.hu/39/1/csicsmann_laszlo.pdf (letöltés: 2011.10.22.)

CZAPLIŃSKI, Marcin [2009]: The OSCE in the New International Environment in Kosovo. In: OSCE Yearbook 2009. pp. 179-189.

DAVIDSON, Douglas [2005]: Ten Years of the OSCE Mission to Bosnia and Herzegovina: Reflections on a Decade and Thoughts on the Future. In: OSCE Yearbook 2005. pp. 125-138.

DoBBINS, James [2008]: Europe's Role in Nation-Building. Survival, 50. évf., 3. sz., pp. $83-110$.

DomM, Rory [2007]: Europeanization without Democratization: A Critique of the International Community Peacebuilding Strategy in Bosnia and Herzegovina. Southeast European and Black Sea Studies, 7. évf., 1. sz., pp. 159-176.

DUCASSE-RogIER, Marianne [2004]: Recovering from Dayton: From 'peace-building' to 'state-building' in Bosnia-hercegovina. Helsinki Monitor, 15. évf., 2. sz., pp. $76-90$

EGEDY Gergely [1998]: Nagy-Britannia története. Aula Kiadó, Budapest

FrIEDMAN, Francine [2004]: Bosnia and Herzegovina. A polity on the brink. Routledge, London and New York. 
FRIEDRICH, Jürgen [2005]: UNMIK in Kosovo: Struggling with Uncertainty. In: von Bogdandy, Armin - Wolfrum, Rüdiger (szerk.): Max Planck Yearbook of United Nations Law. 9. évf., Martinus Nijhoff Publishers, Leiden, pp. 225293.

Fox, Gregory H. [2008]: Humanitarian Occupation. Cambridge University Press.

Gallagher, Tom [2005]: The Balkans in the New Millennium. In the shadow of war and peace. Routledge, London \& New York

GoldmanN, Matthias [2005]: Sierra Leone: African Solution to African Problems? In: von Bogdandy, Armin - Wolfrum, Rüdiger (szerk.): Max Planck Yearbook of United Nations Law. 9. évf., Martinus Nijhoff Publishers, Leiden, pp. 457-515.

GREY, Christine [2008]: International Law and the Use of Force. Oxford University Press.

Grevi, Giovanni - Helly, Damien - KeOHANe, Daniel (szerk.): European Security and Defence Policy. The first ten years (1999-2009). EUISS (European Union Institute for Security Studies), Párizs

GRUSS, Daniel [2005]: UNTEA and West New Guinea. In: von Bogdandy, Armin Wolfrum, Rüdiger (szerk.): Max Planck Yearbook of United Nations Law. 9. évf., Martinus Nijhoff Publishers, Leiden, pp. 97-126.

HALÁsz Iván [2005/a]: A nemzetközi igazgatás a válságövezetekben - adalékok a nemzetközi igazgatás történetéhez és jelenlegi dilemmáihoz. Külügyi Szemle, 4. évf., 1-2. sz.

HALÁSz Iván [2005/b]: Válságkezelő nemzetközi igazgatás Koszovóban. Balkántanulmányok Központ. Forrás: www.balkancenter.hu/pdf/elemzes/halasz02 (letöltés: 2011.06.30.)

HALMAI Gábor et al. [2012]: Nemzetközi Emberi Jogok. E-olvasókönyv. Budapest, 2012. Forrás: tatk.elte.hu (letöltés: 2012. 08.30.)

Halmosy Dénes [1985]: Nemzetközi szerződések 1945-1982. A második világháború utáni korszak legfontosabb külpolitikai szerzödései. Közgazdasági és Jogi Könyvkiadó - Gondolat Könyvkiadó, Budapest

HolBROOKE, Richard [1998]: To End a War. Random House, New York

ICG [1999]: Waiting for UNMIK-Local Administration in Kosovo. Balkans Report ${ }^{\circ}$ 79, Prishtinë/Priština, 18 October 1999. Forrás:

http://www.crisisgroup.org/ /media/Files/europe/Kosovo\%2013 (letöltés: 2011.12.09.)

ICG [2000/a]: Bosnia's Municipal Elections 2000: Winners and Losers. International Crisis Group Balkan Report N¹04, Szarajevó-Brüsszel. Forrás: http://www.crisisgroup.org/ /media/Files/europe/Bosnia\%2036 (letöltés: 2012.04.02.)

ICG [2000/b]: Bosnia's November Elections: Dayton Stumbles. International Crisis Group Balkan Report N¹04, Szarajevó-Brüsszel. Forrás: http://www.crisisgroup.org/ /media/Files/europe/Bosnia\%2037.pdf (letöltés: 2012.04.02.) 
ICG [2001]: Bosnia: Reshaping the International Machinery. International Crisis Group Balkans Report Nº121, Szarajevó-Brüsszel. Forrás:

http://www.crisisgroup.org/ /media/Files/europe/Bosnia 43 (letöltés: 2012.05.13.)

ICG, [2002]: Implementing equality: The "Constituent Peoples" Decision in Bosnia \& Herzegovina. International Crisis Group Balkan Report №128, SzarajevóBrüsszel. Forrás:

http://www.crisisgroup.org/ /media/Files/europe/Bosnia\%2045 (letöltés: 2010.02.27.)

ICG [2003]: Bosnia's Brcko: Getting In, Getting On and Getting Out. International Crisis Group Policy Briefing, Europe Briefing N44, Szarajevó-Brüsszel. Forrás: http://www.crisisgroup.org/ /media/Files/europe/Bosnia\%20144 (letöltés: 2012.03.09)

ICG [2004] Eufor: Changing Bosnia' Security Arrangements. International Crisis Group Europe Briefing $N^{0} 31$, Szarajevó-Brüsszel. Forrás: http://www.crisisgroup.org/en/regions/europe/balkans/bosniaherzegovina/b0031-eufor-changing-bosnias-security-arrangements.aspx (letöltés: 2012.06.27.)

ICG [2005]: Bosnia's Stalled Police Reform. No Progress, No EU. International Crisis Group Europe Report N ${ }^{\circ} 164$, Szarajevó-Brüsszel. Forrás:

http://www.crisisgroup.org/ /media/Files/europe/164_bosnia_stalled_police _reform_no_progress_no_eu (letöltés: 2012.06.29.)

ICG [2009]: Bosnia: A Test of Political Maturity in Mostar. International Crisis Group, Europe Briefing N54, 27 Jul 2009. Forrás: http://www.crisisgroup.org/ /media/Files/europe/b54_bosnia olitical_maturity_in_mostar.pdf (letöltés: 2011.10.07.)

ICG [2011]: Brčko Unsupervised. International Crisis Group Europe Briefing N66, 8 Dec 2011. Forrás: http://www.crisisgroup.org/ /media/Files/europe/balkans/bosniaherzegovina/B66\%20Brcko\%20Unsupervised.pdf (letöltés: 2011.12.10.)

IGAZ Levente [2004]: Portugál gyarmat, indonéz tartomány, független állam: KeletTimor 30 éve. Kitekintő, 1. évf. 3. sz. Forrás: www.kul-vilag.hu (letöltés: 2011.11.19.)

JELAVICH, Barbara [1996]: A Balkán története I, II. Osiris, Budapest

JENSEN, Erik [2005]: Western Sahara: Anatomy of a Stalemate. International Peace Academy Occasional Paper Series. Lynne Rienner Publishers

JuHÁsz József [1999]: Volt egyszer egy Jugoszlávia. A délszláv állam története. Aula, Budapest

JuHÁsz József et al. [2000]: Koszovó. Egy válság anatómiája. Osiris, Budapest

JuHÁsz József - MÁRKuSz László - TÁlAS Péter - VALKI László [2003]: Kinek a békéje? Háború és béke a volt Jugoszláviában. Zrínyi Kiadó, Budapest

JuHÁsz József [2008]: Bosznia-Hercegovina 2006 óta. Az államépítés kudarca? Nemzet és Biztonság, január, pp. 11-19. 
JuDAH, Tim [2008]: Kosovo: What Everyone Needs to Know. Oxford University Press, Oxford

Juncos, Ana E. [2011]: Europeanization by Decree? Th eCase of Police Reform in Bosnia. Journal of Common Market Studies, 49. évf., 2.sz., pp. 367-389.

KAPLAN, Robert D. [1994]: Balkan Ghosts. A journey through history. Picador, New York

KeEn, David [2005]: Conflict \& Collusion in Sierra Leone. Palgrave Macmillan.

KELlER, Lucy [2005]: UNTAC in Cambodia - from Occupation, Civil War and Genocide to Peace. In: von Bogdandy, Armin - Wolfrum, Rüdiger (szerk.): Max Planck Yearbook of United Nations Law. 9. évf., Martinus Nijhoff Publishers, Leiden, pp. 127-178.

KEMENSZKY Ágnes [2008]: A nyugat-balkáni uniós stratégia fejlődési irányai: stabilizáció és/vagy csatlakozás? In: 60 éves Közgáz. A Jubileumi Tudományos Konferencia alkalmából készült tanulmányok: Társadalomtudományi Kar. Budapest, Aula, 2008. 155-171. old.

KeOHANE, David [2009]: EUFOR Althea (Bosnia and Herzegovina). In: Grevi, Giovanni - Helly, Damien - Keohane, Daniel (szerk.): European Security and Defence Policy. The first ten years (1999-2009). EUISS (European Union Institute for Security Studies), Párizs, pp. 211-220.

KInG, Ian - MASON, Whit [2006]: Peace at any price. How the world failed Kosovo. Hurst, London

KNAUER, Jannik [2011]: EUFOR Althea: Appraisal and Future Perspectives of the EU's Former Flagship Operation in Bosnia and Herzegovina. College of Europe. Department of EU Internatinal Relations and Diplomacy Studies. EU Diplomacy Papers 7/2011, Bruges

KonDOCH, Boris [2001]: The United Nations Administration in East Timor. Journal of Conflict and Security Law, 6. évf., 2. sz., pp. 245-265.

LEHOCZKI Bernadett [2004]: A fejlődő államok részvétele az ENSZ békefenntartó tevékenységében - különös tekintettel Pakisztánra. Kül-világ, 1. évf., 3. sz. Forrás: http://www.kul-vilag.hu/2004/03/lehoczki.pdf (letöltés: 2011.07.22.)

LEMAY-HÉBERT, Nicolas [2009]: State-Building from the Outside-In: UNMIK and its Paradox. Journal of Public and International Affairs, 20. évf., tavaszi sz., pp. $65-86$.

LINDLEY-FRENCH, Julian [2003]: Kapcsolatok, amelyek összekötnek. NATO Tükör, 2003 ösz, 3. sz. Forrás:

http://www.nato.int/docu/review/2003/issue3/hungarian/art2.html (letöltés: 2012.06.27.)

Malcolm, Noel [1996]: Bosnia. A Short History. Papermac, London

Malcolm, Noel [2002]: Kosovo. A Short History. Pan Books, London

MALONE, David M. - THAKUR, Ramesh [2001]: UN Peacekeeping: Lessons Learned? Global Governance, 7. évf. 1. sz., pp. 11-17. 
MARTON Péter [2009]: Az államépítés sorrendisége és az afganisztáni bonyodalmak. Külügyi Szemle, 1. sz., pp. 18-40.

MARR, Phebe [2011]: The Modern History of Iraq. Westview Press

MATZ, Nele [2005]: Civilization and the Mandate System under the League of Nations as Origin of Trusteeship, Case Studies. In: von Bogdandy, Armin Wolfrum, Rüdiger (szerk.): Max Planck Yearbook of United Nations Law. 9. évf., Martinus Nijhoff Publishers, Leiden, pp. 47-95.

MERLINGEN, Michael [2009]: EUPM (Bosnia and Herzegovina). In: Grevi, GiovanniHelly, Damien - Keohane, Daniel (szerk.): European Security and Defence Policy. The first ten years (1999-2009). EUISS (European Union Institute for Security Studies), Párizs, pp. 161-172.

MerLingen, Michael - OstrausKaité, Rasa (szerk.): European Security and Defence Policy. An Implementation Perspective. Routledge, London

MÜHLman, Tomas [2008]: The Police Mission EUPM in Bosnia, 2003-05. In: Merlingen, Michael - Ostrauskaité, Rasa (szerk.): European Security and Defence Policy. An Implementation Perspective. Routledge, London, pp. 4366.

OELLERS-FrAHM, Karin [2005]: Restructuring Bosnia-Herzegovina. A Model with PitFalls. In: von Bogdandy, Armin - Wolfrum, Rüdiger (szerk.): Max Planck Yearbook of United Nations Law. 9. évf., Martinus Nijhoff Publishers, Leiden, pp. 179-224.

OLIVA, Fabio [2007]: Between contribution and disengagement: Postconflict elections and the OSCE role in the normalization of armed groups and militarized political parties in Bosnia and Herzegovina, Tajikistan, and Kosovo. Helsinki Monitor, 18. évf., 3. sz., pp. 192-207.

Ó TuATHAIL, Gearóid [2006]: Geopolitical Discourses: Paddy Ashdown and the Tenth Anniversary of the Dayton Peace Accords. Geopolitics, 11. évf., 1. sz., pp. 141. -158 .

PAP András László [1999]: Az etnicitás mint a politikai képviselet alapja. Megjegyzések a nemzeti és etnikai kisebbségek parlamenti

képviseletéhez. Politikatudományi Szemle, 4. sz., pp. 23-47.

Pellet, Alain [1992]: The Opinions of the Badinter Arbitration Committee. A Second Breath for the Self-Determination of Peoples. European Journal of International Law, 3. évf., 1. sz., pp. 178-181.

PHILIPP, Christiane E. [2005]: Somalia - A Very Special Case, Cross Cutting Issues. In: von Bogdandy, A. - Wolfrum, R. (szerk.): Max Planck Yearbook of United Nations Law. 9. évf., Martinus Nijhoff Publishers, Leiden, pp. 517-554.

PolgÁRI Eszter [2010]: Az Emberi Jogok Európai Bíróságának legutóbbi döntéseiből. Fundamentum, 14. évf., 1. sz., pp. 77-83.

PRANDLER Árpád (szerk.) [2011]: Nemzetközi szervezetek és intézmények. Aula Kiadó, Budapest

RAtNer, Steven R. [1997]: The New UN Peacekeeping. Building Peace in Lands of Conflict After the Cold War. Palgrave Macmillan 
RECCHIA, Stefano [2007]: Beyond International Trusteeship: EU peacebuilding in Bosnia and Herzegovina. Institute for Security Studies (ISS) Occasional Paper $\mathrm{n}^{\mathrm{o}}$ 66.Forrás: http://www.iss.europa.eu/uploads/media/occ66.pdf (letöltés: 2010.03.25.)

RitTBerger, Volker - ZAngL, Bernhard [2006]: International Organization. Polity, Politics and Policies. Palgrave Macmillan

RostovÁnYi Zsolt (szerk.): Az iszlám Európában. Az európai muszlim közösségek differenciáltsága. Budapest, Aula, 2010

SCHEDLER, Andreas - DiAMOND, Larry - Plattner, Marc F. (szerk.): The SelfRestraining State. Power and Accountability in New Democracies. Lynne Rienner Publishers, London

ŠElo ŠABIĆ, Senada [2005]: State Building Under Foreign Supervision: Intervention in Bosnia-Herzegovina 1996-2003. Landesverteidigungsakademie, Bécs

SEMANIĆ, Hana [2011]: EU-integráció szeparáció által. Etnikai csoportok intézményesítése Bosznia-Hercegovinában. Pro Minoritate, Ösz, pp. 57-66.

SIANI-DAVIES, Peter (szerk.) [2003]: International Intervention in the Balkans since 1995. Routledge, London and New York

SIPRI YEARBOOK [1996] Oxford University Press, Oxford

SKLAR, Richard L. [1999]: Democracy and Constitutionalism. In: Schedler, Andreas Diamond, Larry - Plattner, Marc F. (szerk.): The Self-Restraining State. Power and Accountability in New Democracies. Lynne Rienner Publishers, London, pp. 53-58.

SøBERG, Marius [2008]: The Quest for Institutional Reform in Bosnia and Herzegovina. East European Politics and Societies, 22. évf., 4. sz., pp. 714-737.

SolIOZ, Christophe [2005]: Turning Points in Post-War Bosnia: Ownership Process and European Integration. Sorozatcím: Democracy, Security, Peace / Demokratie, Sicherheit, Frieden. Nomos, Baden-Baden

Sollenberg, Margareta - WALlensteen, Peter [1996]: Major Armed Conflicts. In: SIPRI Yearbook 1996. Oxford University Press, Oxford, pp.15-30.

STAHN, Carsten [2001]: The United Nations Transitional Administrations in Kosovo and East Timor: A First Analysis. In: von Bogdandy, Armin - Wolfrum, Rüdiger (szerk.): Max Planck Yearbook of United Nations Law. 5. évf., Martinus Nijhoff Publishers, Leiden

StAHN, Carsten [2008]: The Law and Practice of International Territorial Administration. Versailles to Iraq and Beyond. Cambridge Unoversity Press, Cambridge

STROHMEYER, Hansjörg [2001]: Collapse and Reconstruction of a Judicial System: The United Nations Mission in Kosovo and East Timor. American Journal of International Law, 95. év. 1. sz., pp. 46-63.

TANSEY, Oisín [2007]: Democratization without a State: Democratic Regime-building in Kosovo. Democratization, 14. évf., 1. sz., pp. 129-150. 
TANSEY, Oisín [2009]: Regime-building. Democratization and International Administration. Oxford University Press, Oxford

TrauB, James [2000]: Inventing East Timor. Foreign, Affairs, 79. évf. 4. sz., pp. 74-89.

YANNIS, Alexandros [2001]: Kosovo Under International Administration. Survival, 43. évf., 2. sz., pp. 31-48.

VON BOGDANDY, Armin - WOLFRUM, Rüdiger (szerk.): Max Planck Yearbook of United Nations Law. 5. évf., Martinus Nijhoff Publishers, Leiden

VON BOGDANDY, Armin - WolfRUM, Rüdiger (szerk.): Max Planck Yearbook of United Nations Law. 9. évf. , Martinus Nijhoff Publishers, Leiden

Wentz, Larry [1997]: Lessons from Bosnia: The IFOR experience. DoD Command and Control Research Program (CCRP) - The National Defence University

WILDE, Ralph [2001]: From Danzig to East Timor and Beyond: The Role of International Territorial Administration. The American Journal of International Law, 95. évf., 3. sz., pp. 583-606.

WILDE, Ralph [2004]: Representing International Territorial Administration: A Critique of Some Approaches. European Journal of International Law, 15. évf., 15. sz., pp. 71-96.

WILDE, Ralph [2008]: International Territorial Administration. How trusteeship and Civilizing Mission Never Wenr Away. Oxford University Press, Oxford

Williams, Paul R. - Pecci, Francesca Janotti [2004]: Earned Sovereignty: Bridging the Gap between Sovereignty and Self-Determination. Stanford Journal of International Law, 40. évf., 1. sz.

WolfRUM, Rüdiger [2005]: International Administration in Post-Conflict Situations by the United Nations and Other International Actors. In: von Bogdandy, Armin - Wolfrum, Rüdiger (szerk.]: Max Planck Yearbook of United Nations Law. 9. évf., pp. 649-696.

ZAKARIA, Fareed [1997]: The Rise of Illiberal Democracy. Foreign Affairs, 76. évf., 6. sz., pp. 22-43.

ZAuM, Dominik [2007]: The Sovereignty Paradox. The Norms and Politics of International Statebuilding. Oxford University Press, Oxford

\section{Nemzetközi szervezetek, állami intézmények honlapjainak közleményei, sajtóanyagai}

A/53/951-S/1999/513 [1999] Agreement between the Republic of Indonesia and the Portuguese Republic on the question of East Timor. Forrás:

http://www.un.int/portugal/acordos.htm (letöltés: 2010.11.19.)

A/56/875-S/2002/278 [2002] The situation in Afghanistan and its implications for international peace and security. Report of the Secretary-General. Forrás: http://unama.unmissions.org/Portals/UNAMA/SG\%20Reports/18\%20March \%202002.pdf (letöltés: 2011.07.23.) 
A/RES/1542(XV) [1960] Transmission of information under Article 73 of the Charter. Forrás: http://www.un.org/documents/ga/res/15/ares15.htm (letöltés: 2010.11.19.)

A/RES/1752(XII) [1962] Agreement between the Republic of Indonesia and the Kingdom of the Netherlands concerning West New Guinea (West Irian) Forrás: http://daccess-ddsny.un.org/doc/RESOLUTION/GEN/NR0/192/60/IMG/NR019260.pdf?Open Element (letöltés: 2011.10.11.)

A/RES/2145(XXI) [1966] Question of South West Africa. Forrás: http://daccess-ddsny.un.org/doc/RESOLUTION/GEN/NR0/004/48/IMG/NR000448.pdf?Open Element (letöltés. 2011.09.12.)

A/RES/3485 (XXX) [1975] Question of Timor. Forrás: http://www.un.org/depts/dhl/resguide/r30.htm (letöltés. 2011.09.14.)

AB határozat U-5/98-III. [2000] Bosznia-Hercegovina Alkotmánybírósága, 2000. július 1. Forrás: http://www.ccbh.ba/bos/odluke/povuci_html.php?pid=22211 (letöltés: 2012.07.12.); angol nyelven: Főmegbízott Hivatala Forrás: http://www.ohr.int/ohr-dept/legal/const/default.asp?content_id=5853 (letöltés: 2012.07.12.)

Advisory Opinion of 11 July 1950 - International Status of South West Africa (including the text of the declaration of Judges Guerrero, Zoricic et Badawi Pasha) http://www.icj-cij.org/docket/files/10/8931.pdf (letöltés: 2011.09.12.)

Agreement Among the People's Republic of Angola, the Republic of Cuba, and the Republic of South Africa. Forrás:

http://lcweb2.loc.gov/frd/cs/angola/ao_appnb.html (letöltés: 2011.10.11.)

Agreement between the Republic of Indonesia and the Portuguese Republic on the question of East Timor Forrás: http://www.un.int/portugal/acordos.htm (letöltés. 2011.09.12.)

Agreement on a Comprehensive Political Settlement of the Cambodia Conflict. Forrás: http://www.usip.org/sites/default/files/file/resources/collections/peace_agree ments/agree_comppol_10231991.pdf(letöltés: 2011.09.12.)

Ahtisaari-terv [2007]: Comprehensive proposal for the Kosovo Status Settlement. Forrás: http://www.unosek.org/docref/Comprehensive_proposal-english.pdf (letöltés: 2011.07.07.)

An Agenda for Peace [1992] An Agenda for Peace. Preventive diplomacy, peacemaking and peace-keeping. A/47/277 - S/24111, 17 June 1992 Forrás:

http://www.unrol.org/files/A_47_277.pdf(letöltés: 2011.07.23.)

Basic Agreement on The Region of Eastern Slavonia, Baranja, And Western Sirmium.

Forrás:

http://www.usip.org/files/file/resources/collections/peace_agreements/croati a_erdut_11121995.pdf (letöltés: 2010.09.16.) 
Bécsi egyezmény [1963] 1987. évi 12. törvényerejü rendelet szerzödések jogáról szóló, Bécsben az 1969. évi május hó 23. napján kelt szerzödés kihirdetéséröl. Forrás:

http://www.kulugyminiszterium.hu/kum/hu/bal/Kulpolitikank/Jogszabalyok/ nemzetkozi_dipl_konzuli_jog/BE_szerzodesek_jogarol.htm (letöltés: 2012.01.08.)

Bosznia-Hercegovina Alkotmánybírósága [é. n.]: Forrás: http://www.ccbh.ba/ (letöltés: 2012.08.05.)

Bosznia-Hercegovina Központi Bankja [é. n.]: Forrás: http://cbbh.ba (letöltés: 2012.08.06.)

Bosznia-Hercegovina Központi Választási Bizottsága [é. n.]: Centralna izborna komisija Bosne i Hercegovine. Forrás: http://www.izbori.ba (letöltés: 2012.08.02.)

Bosznia-hercegovinai Elnökség (Bosna i Hercegovina, Predsjedništvo) [é. n.]: Forrás: http://www.predsjednistvobih.ba (letöltés: 2012.07.24.)

Bosznia-hercegovinai Minisztertanács [é. n.]: Forrás: http://www.vijeceministara.gov.ba/ (letöltés: 2012.08.05.)

Bosznia-hercegovinai Föderáció alkotmánya [1994] Forrás: http://legislationline.org/download/action/download/id/1577/file/cf85ae3b01 cladcd1b6eed4a3b84.htm/preview (letöltés: 2012.05.09.)

Bosznia-hercegovinai Föderáció kormánya [é. n.]: Forrás: http://www.fbihvlada.gov.ba. (letöltés: 2012.07.21.)

Bosznia-hercegovinai Föderáció Legfelsőbb Bírói és Ügyészi Tanácsa [é. n.]: Forrás: http://www.hjpc.ba (letöltés: 2012.06.29.)

Bosznia-hercegovinai Föderáció parlamentje [é. n.]: Forrás: http://www.parlamentfbih.gov.ba (letöltés: 2012.07.21.)

Brcko Arbitral Tribunal for Dispute Over the Inter-Entity Boundary in Brcko Area Award. Arbitration for the Brcko Area. The Republika Srpska v. The Federation of Bosnia and Herzegovina. Final Award. Főmegbízott Hivatala, 1997. február 14. http://www.ohr.int/ohroffices/brcko/default.asp?content_id=5327 (letöltés: 2012.03.09)

Brcko Arbitral Tribunal for Dispute Over the Inter-Entity Boundary in Brcko Area Award. Arbitration for the Brcko Area. The Republika Srpska v. The Federation of Bosnia and Herzegovina. Annex to Final Award. Fömegbízott Hivatala, 1999. augusztus 18. http://www.ohr.int/ohroffices/brcko/default.asp?content_id=5362 (letöltés: 2012.03.09)

Constitutional Court of Bosnia and Hercegovina, Decision No. U 9/00, 3 November 2000 Forrás: http://www.ccbh.ba/eng/odluke/povuci_html.php?pid=22419 (letöltés: 2012.08.14.)

Daytoni megállapodás. [1995] The General Framework Agreement for Peace in Bosnia and Herzegovina. 14/12/1995. Office of the High Representative. Forrás: http://www.ohr.int/dpa/default.asp? content_id=380 (letöltés: 2012.04.05.)

DPKO [2003]: Handbook on United Nations Multidimensional Peacekeeping Operations. Department of Peacekeeping Operations, United Nations 
EBESZ [é. n./a]: OSCE Office for Democratic Institutions and Human Rights. Bosnia and Herzegovina. Forrás: http://www.osce.org/odihr/elections/bih/66559 (letöltés: 2012.08.02.)

EBESZ Koszovói Misszió [é. n.]: OSCE Mission in Kosovo. Forrás: http://www.osce.org/kosovo/100512 (letöltés: 2012.08.25.)

Eide-jelentés [2005]: A comprehensive review of the situation in Kosovo. S/2005/635 7 October 2005, Forrás: http://www.unosek.org/docref/KaiEidereport.pdf (letöltés: 2011.10.08.)

ENSZ Ao. [1945]: Egyesült Nemzetek Alapokmánya. Magyar ENSZ Társaság. Forrás: http://www.menszt.hu/tudnivalok_az_egyesult_nemzetek_szervezeterol/az_e gyesult_nemzetek_alapokmanya/az_egyesult_nemzetek_alapokmanya (2012.03.09)

EUFORBiH [é. n./a] EUFOR Fact Sheet - Countries of EUFOR. Forrás: http://www.euforbih.org/index.php?option $=$ com_content\&view=article\&id= $15 \% 3$ Aeufor-fact-sheet\&catid=185\%3Aabouteufor\&Itemid=134\&limitstart=2 (letöltés: 2012.06.27.)

EUFORBiH [é. n./b] EUFOR Fact Sheet-Military Forces. Forrás: http://www.euforbih.org/index.php?option=com_content\&view=article\&id= 15\%3Aeufor-fact-sheet\&catid=185\%3Aabout-eufor\&Itemid=134 (letöltés: 2012.06.27.)

EUPM [é. n.] Overview. EUPM honlapja. Forrás: http://www.eupm.org/Overview.aspx (letöltés: 2012.06.29.)

Európai Unió Tanácsa [2002] Council Joint Action on the European Police Mission, 2002/210/CFSP, Brussels, 11 March 2002 Forrás: http://www.eupm.org/Documents/councill.pdf (letöltés: 2012.06.29.)

Európai Unió Tanácsa [2003]: EU-NATO: The Framework for Permanent Relations and Berlin plus. (Background) Forrás: http://www.consilium.europa.eu/uedocs/cmsUpload/03-11-11 Berlin Plus press note BL.pdf (letöltés: 2012.06.27.)

Európai Unió Tanácsa [2006]: Common Operational Guidelines for EUPM-EUFOR support to the fight against organised crime, Council Doc. 10769/06, Brussels, 21 June 2006 Forrás: http://register.consilium.europa.eu/pdf/en/06/st10/st10769-re01.en06.pdf (letöltés: 2012.06.29.)

Európai Unió Tanácsa [2007]: Press Release - 2789th Council meeting - General Affairs and External Relations, Council Doc. 6756/07 (Presse 39), Brussels, 5 March 2007 Forrás: http://www.consilium.europa.eu/uedocs/cmsUpload/Council_Conclusions05.03.07.pdf (letöltés: 2012.06.27.)

Európai Unió Tanácsa [2010]: Press Release - 2992nd Council meeting - Foreign Affairs, Council Doc. 5686/10 (Presse 10), Brussels, 25 January 2010 Forrás: http://www.consilium.europa.eu/uedocs/cms_data/docs/pressdata/EN/foraff/ 112569.pdf (letöltés: 2012.06.27.) 
Helsinki megállapodás [1999]: Agreed Points on Russian Participation in KFOR. Forrás: http://www.nato.int/kosovo/docu/a990618a.htm (letöltés: 2011.12.11.)

ICISS -International Commission on Intervention and State Sovereignty. The Responsibility to Protect. Report of the International Commission on Intervention and State Sovereignty. 2001. Forrás: http://responsibilitytoprotect.org/ICISS\%20Report.pdf (letöltés: 2012.06.10.)

Islamic Republic of Afghanistan Afghanistan National Development Strategy 1387 1391 (2008 - 2013). Forrás:

http://www.undp.org.af/publications/KeyDocuments/ANDS_Full_Eng.pdf (letöltés: 2011.07.23.)

Judgment of 18 July 1966 - South West Africa (Liberia v. South Africa) és Judgment of 18 July 1966 - South West Africa (Ethiopia v. South Africa) http://www.icjcij.org/docket/files/47/4955.pdf (letöltés: 2011.09.12.)

Koszovó alkotmánya [2008]: Kushtetuta e Republikës së Kosovës. Forrás: http://www.assembly-kosova.org/common/docs/Constitutionl of the Republic of Kosovo.pdf (letöltés: 2012.08.28.)

Koszovói államfö hivatala [é. n.]: Presidenti Republikës së Kosovës. Forrás: http://www.president-ksgov.net/ (letöltés: 2012.08.20.)

Koszovó Központi Választási Bizottsága [é. n.]: Komisioni Qendror i Zgjedjheve. Forrás: http://www.kqz-ks.org/ (letöltés: 2012.08.25.)

Koszovó miniszterelnöki hivatala [é. n.] Zyra e Kryeministrit. Forrás: http://www.kryeministri-ks.net (letöltés: 2012.08.28.)

Kumanovói megállapodás [1999] Military TechnicalAgreement between the International Security Force ("KFOR") and the Government of the Federeal Republic of Yugoslavia and the Republic of Serbia. 9 June 1999. Forrás: http://www.nato.int/kosovo/docu/a990609a.htm (letöltés: 2011.11.02.]

Nacionalni sastav stanovništva [1993] Federalni zavod za statistiku. Forrás: http://www.fzs.ba/popis.htm\#_POPIS\%20STANOVNI\%C5\%A0TVA\%201 991 (letöltés: 2012.07.19.)

NATO [é. n./a] SFOR ends on 2 December. NATO honlapja, Newsroom. 2004. dec. 1. Forrás: http://www.nato.int/cps/en/natolive/news_20645.htm?selectedLocale=en (letöltés: 2012.06.27.)

NATO [é. n./b] NATO ends SFOR mission. NATO honlapja, Newsroom. 2004. dec. 2. Forrás:

http://www.nato.int/cps/en/natolive/news_20646.htm?selectedLocale=en (letöltés: 2012.06.27.)

NATO KFOR [2012] Kosovo Force (KFOR) Troop Contributions. Forrás: http://www.nato.int/kfor/structur/nations/placemap/kfor_placemat.pdf (letöltés: 2012.08.17.)

NATO SFOR [é. n.] SFOR Stabilization Force Forrás: http://www.nato.int/sfor/index.htm (letöltés: 2012.05.08.) 
NATO SFOR CIMIC [é. n.] SFOR Informer Online. A presentation of CIMIC. Forrás: http://www.nato.int/sfor/cimic/introduction/cimic.htm (letöltés: 2012.05.08.)

OHR döntés [2002/a.] Decision on Constitutional Amendments in Republika Srpska. Főmegbízott Hivatala, 2002. április 19. Forrás:

http://www.ohr.int/decisions/statemattersdec/default.asp?content id=7474 (letöltés: 2012.07.12.)

OHR döntés [2002/b.] Decision on Constitutional Amendments in the Federation. Főmegbízott Hivatala, 2002. április 19. Forrás:

http://www.ohr.int/decisions/statemattersdec/default.asp?content_id=7475 (letöltés: 2012.07.12.)

OHR döntés [2002/c.] Decision amennding the BiH Election Law in accordance with the new Entity Constitutions. Főmegbízott Hivatala, 2002. április 19. Forrás: http://www.ohr.int/decisions/statemattersdec/default.asp?content_id=7476 (letöltés: 2012.07.12.)

PC.DEC/305 [1999] OSCE Permanent Council Decision No. 305 of 1 July 1999. Forrás: http://www.osce.org/pc/28795 (letöltés: 2012.03.17.)

Peace Agreement Between the Government of Sierra Leone and the Revolutionary United Front of Sierra Leone. Forrás: http://www.scsl.org/scsl/Public/SCSL-03-13-Kanu/SCSL-03-13-PT-028/SCSL-03-13-PT028-IX.pdf (letöltés: 2011.11.24.)

Popis stanovništva, domaćinstava, stanova i poljoprivrednih gazdinstava 1991. Forrás: http://www.fzs.ba/Dem/Popis/Etnicka\%20obiljezja\%20stanovnistva\%20bilt en\%20233.pdf (letöltés: 2011.04.18.)

President Woodrow Wilson's Fourteen Points. Forrás:

http://avalon.law.yale.edu/20th_century/wilson14.asp (letöltés: 2010.08.05.)

Rambouillet Accords [1999] Interim Agreement for Peace and Self-Government in Kosovo, 23 February 1999. Forrás.

http://www.un.org/peace/kosovo/sc_kosovo.htm (letöltés: 2011.10.09.)

Republika Srpska alkotmánya [1992] Forrás:

http://legislationline.org/download/action/download/id/1580/file/c8ea79bc0d b11c11f49f19525f43.htm/preview (letöltés: 2012.05.09.)

Republika Srpska kormánya [é. n.]: Forrás. http://www.vladars.net (letöltés: 2012.07.21.)

Republika Srpska Nemzetgyülés [é. n.]: Forrás: http://www.narodnaskupstinars.net (letöltés: 2012.07.21.)

Republika Srpska Népek Tanácsa [é. n.]: Forrás: http://vijecenarodars.net (letöltés: 2012.07.21.)

Republika Srpska szenátusa [é. n.]: Forrás: http://www.predsjednikrs.net/index.php?option=com_content\&view=categor

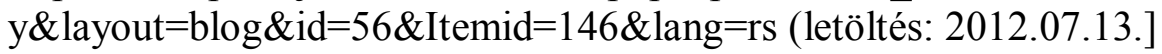

S/1999/779 [1999] Report of the Secretary-General on the United Nations Interim Administration Mission in Kosovo. 12 July 1999. Forrás: http://www.un.org/en/peacekeeping/missions/unmik/reports.shtml (letöltés: 2011.08.22.) 
S/RES/143 [1960] Security Council Resolution of 14 July 1960. Forrás: http://www.unhcr.org/refworld/country,,,RESOLUTION,COG,,3b00f00d50, 0.html (letöltés: 2011.10.11.)

S/RES/384 [1975] Security Council Resolution of 22 December 1975.

Forrás: http://daccess-ddsny.un.org/doc/RESOLUTION/GEN/NR0/782/32/IMG/NR078232.pdf?Open Element (2011.09.12.)

S/RES/389 [1976] Security Council Resolution of 22 April 1976. Forrás: http://daccessdds-

ny.un.org/doc/RESOLUTION/GEN/NR0/294/77/IMG/NR029477.pdf?Open Element (2011.09.12.)

S/RES/435 [1978] Security Council Resolution of 29 September 1978. Forrás: http://daccess-ddsny.un.org/doc/RESOLUTION/GEN/NR0/368/80/IMG/NR036880.pdf?Open Element (letöltés: 2011.09.12.)

S/RES/687 [1991] Security Council Resolution of 3 April 1991. Forrás: http://www.un.org/Docs/scres/1991/scres91.htm (letöltés: 2011.10.29.)

S/RES/690 [1991] Security Council Resolution of 29 April 1991. Forrás: http://www.un.org/Docs/scres/1991/scres91.htm (letöltés: 2011.10.29.)

S/RES/743 [1992] Security Council Resolution of 21 February 1992. Forrás: http://www.un.org/documents/sc/res/1992/scres92.htm (letöltés: 2011.02.21.)

S/RES/745 [1992] Security Council Resolution of 28 February 1992. Forrás: http://www.un.org/documents/sc/res/1992/scres92.htm (letöltés: 2011.09.20.)

S/RES/751 [1992] Security Council Resolution of 24 April 1992. Forrás: http://www.un.org/documents/sc/res/1992/scres92.htm (leöltés: 2011.09.23.)

S/RES/781 [1992] Security Council Resolution of 9 October 1992. Forrás: http://www.un.org/documents/sc/res/1992/scres92.htm (letöltés: 2011.02.21.)

S/RES/792 [1992] Security Council Resolution of 11 December 1992. Forrás: http://www.un.org/documents/sc/res/1992/scres92.htm (letöltés: 2011.02.21.)

S/RES/794 [1992] Security Council Resolution of 3 December 1992. Forrás: http://www.un.org/documents/sc/res/1992/scres92.htm (leöltés: 2011.09.23.)

S/RES/814 [1993] Security Council Resolution of 26 March 1993. Forrás: http://www.un.org/Docs/scres/1993/scres93.htm (letöltés: 2011.09.23.)

S/RES/819 [1993] Security Council Resolution of 16 April 1993. Forrás: http://www.un.org/Docs/scres/1993/scres93.htm (letöltés: 2011.09.23.)

S/RES/824 [1993] Security Council Resolution of 6 May 1993. Forrás: http://www.un.org/Docs/scres/1993/scres93.htm (letöltés: 2011.09.23.) 
S/RES/836 [1993] Security Council Resolution of 4 June 1993. Forrás: http://www.un.org/Docs/scres/1993/scres93.htm (letöltés: 2011.02.21.)

S/RES/954 [1994] Security Council Resolution of 4 November 1994. Forrás: http://www.un.org/Docs/scres/1994/scres94.htm (letöltés: 2011.09.23.)

S/RES/1031 [1995] Security Council Resolution of 15 December 1995. Forrás: http://www.un.org/Docs/scres/1995/scres95.htm (letöltés: 2011.02.21.)

S/RES/1037 [1996] Security Council Resolution of 15 January of 1996. Forrás: http://www.un.org/Docs/scres/1996/scres96.htm (letöltés: 2010.09.16.)

S/RES/1088 [1996] Security Council Resolution of 15 January 1996. Forrás: http://www.un.org/Docs/scres/1996/scres96.htm (letöltés: 2011.02.21.)

S/RES/1181 [1998] Security Council Resolution of 13 July 1998. Forrás: http://www.un.org/Docs/scres/1998/scres98.htm (letöltés: 2011.11.24.)

S/RES/1199 [1998] Security Council Resolution of 23 September 1998. Forrás: http://www.un.org/peace/kosovo/98sc1199.htm (letöltés: 2012.03.17.)

S/RES/1244 [1999] Security Council Resolution of 10 June 1999. Forrás: http://www.un.org/Docs/scres/1999/sc99.htm (letöltés: 2010.08.05.)

S/RES/1246 [1999] Security Council Resolution of 11 June 1999. Forrás: http://www.un.org/Docs/scres/1999/sc99.htm (letöltés: 2010.11.19.)

S/RES/1264 [1999] Security Council Resolution of 15 September 1999. Forrás: http://www.un.org/Docs/scres/1999/sc99.htm (letöltés: 2011.11.29.)

S/RES/1270 [1999] Security Council Resolution of 22 October 1999. Forrás: http://www.un.org/Docs/scres/1999/sc99.htm (letöltés: 2011.11.24.)

S/RES/1272 [1999] Security Council Resolution of 25 October 1999. Forrás: http://www.un.org/Docs/scres/1999/sc99.htm (letöltés: 2011.11.29.)

S/RES/1386 [2001] Security Council Resolution of 20 December 2001. Forrás: http://www.un.org/Docs/scres/2001/sc2001.htm (letöltés: 2011. 07.23.)

S/RES/1401 [2002] Security Council Resolution of 28 March 2002. Forrás: http://www.un.org/Docs/scres/2001/sc2001.htm (letöltés: 2011.07.23.)

S/RES/1410 [2002] Security Council Resolution of 17 May 2002. Forrás: http://www.un.org/en/peacekeeping/missions/past/unmiset/res.html (letöltés: 2011.11.29.)

S/RES/1500 [2003] Security Council Resolution of 14 August 2003. Forrás: http://www.un.org/Docs/sc/unsc_resolutions03.html (letöltés: 2011.10.29.)

S/RES/1599 [2005] Security Council Resolution of 28 April 2005. Forrás: http://www.un.org/en/peacekeeping/missions/past/unmiset/res.html (letöltés: 2011.11.29.)

S/RES/1704 [2006] Security Council Resolution of 25 August 2006. Forrás: http://www.un.org/ga/search/view_doc.asp?symbol=S/RES/1704\%282006\% 29 (letöltés: 2011.11.29.) 
Sejdić és Finci ügy. Judgement in the case of Sejdić and Finci v. Bosnia-Herzegovina. Emberi Jogok Európai Bírósága, Strasbourg, 2009. december 22. Forrás: http://hudoc.echr.coe.int/sites/eng/pages/search.aspx?i=001-96491 (letöltés: 2012.07.12.)

Stability Pact for South Eastern Europe [1999] Sarajevo Summit Declaration. 30 July 1999. Forrás: http://www.stabilitypact.org/constituent/990730-sarajevo.asp (Letöltve: 2008. augusztus 5.)

The Afghanistan Compact. Forrás:

http://www.nato.int/isaf/docu/epub/pdf/afghanistan_compact.pdf(letöltés: 2011.07.23.)

The Responsibility to Protect. Report of the International Commission on Intervention and State Sovereignty. 2001. Forrás: http://responsibilitytoprotect.org/ICISS\%20Report.pdf (letöltés: 2012.06.10.)

The Situation Concerning Western Sahara. Report of the Secretary General. 18 June 1990. Forrás: http://www.un.org/ga/search/view_doc.asp?symbol=S/21360 (letöltés: 2011.05.24.)

The Situation Concerning Western Sahara. Report of the Secretary General. 19 April 1991.Forrás: http://www.un.org/ga/search/view_doc.asp?symbol=S/22464 (letöltés: 2011.05.24.) (letöltés: 2011.05.24.)

UN - UNAMI mandate. [é. n.] Forrás: http://www.uniraq.org/aboutus/mandate.asp (letöltés: 2011.10.27)

UN [é. n./a] The United Nations and Decolonizations. Non-Self-Governing Territories. http://www.un.org/en/decolonization/nonselfgovterritories.shtml\#foot2 (letöltés: 2011.03.12.)

UN [é. n./b] Declaration on the granting of independence to colonial countries and peoples. Forrás: http://daccess-ddsny.un.org/doc/RESOLUTION/GEN/NR0/152/88/IMG/NR015288.pdf?Open Element (letöltés: 2011.07.03.)

UNMIK/REG/1999/1 [1999] Regulation No. 1991/1 On the Authority of the Interim Administration in Kosovo, 25 July 1999 Forrás: http://www.unmikonline.org/regulations/1999/re99_01.pdf(letöltés: 2011.06.22.)

UN Peacekeeping Operations - MINURSO. [é. n.] Forrás: http://www.un.org/en/peacekeeping/missions/minurso/ (letöltés: 2011.05.24.)

UN Peacekeeping Operations - ONUC. [é. n.] Forrás: http://www.un.org/en/peacekeeping/missions/past/onuc.htm (letöltés: 2011.10.11.)

UN Peacekeeping Operations - UNAMA. [é. n.] Forrás: http://unama.unmissions.org/ (letöltés: 2011.07.23.)

UN Peacekeeping Operations - UNMIBH. [é. n.] Forrás: http://www.un.org/en/peacekeeping/missions/past/unmibh/ (letöltés: 2011.10.07.) 
UN Peacekeeping Operations - UNMIK. [é. n.] Forrás: http://www.unmikonline.org/ (letöltés. 2011.08.05.)

UN Peacekeeping Operations - UNMISET. [é. n.] Forrás:

http://www.un.org/en/peacekeeping/missions/past/unmiset/ (letöltés:

2011.11.29)

UN Peacekeeping Operations - UNOSOM I. [é. n.] Forrás:

http://www.un.org/en/peacekeeping/missions/past/unosomi.htm (letöltés:

2011.09.23.)

UN Peacekeeping Operations - UNOSOM II. [é. n.] Forrás:

http://www.un.org/en/peacekeeping/missions/past/unosom2.htm (letöltés:

2011.09.23.)

UN Peacekeeping Operations - UNPROFOR. [é. n.] Forrás:

http://www.un.org/en/peacekeeping/missions/past/unprofor.htm (letöltés:

2012.07.23.)

UN Peacekeeping Operations - UNSF. [é. n.] Forrás:

http://www.un.org/en/peacekeeping/missions/past/unsf.htm (letöltés:

2011.10.11.)

UN Peacekeeping Operations - UNTAC. [é. n.] Forrás:

http://www.un.org/en/peacekeeping/missions/past/untac.htm (letöltés:

2011.09.20.)

UN Peacekeeping Operations - UNTAES. [é. n.] Forrás:

http://www.un.org/en/peacekeeping/missions/past/untaes.htm (2011.09.23.)

UN Peacekeeping Operations - UNTAET. [é. n.] Forrás:

http://www.un.org/en/peacekeeping/missions/past/etimor/etimor.htm (2011.09.23.)

UN Peacekeeping Operations - UNTAG. [é. n.] Forrás:

http://www.un.org/en/peacekeeping/missions/past/untag.htm (letöltés:

2011.09.12.)

UN-Committee of 24 (Special Committee on Decolonization) [é. n.] Forrás: http://www.un.org/en/decolonization/specialcommittee.shtml (letöltés: 2011.09.05.)

Washingtoni megállapodás. USIP (United States Institute of Peace) Forrás:

http://www.usip.org/files/file/resources/collections/peace_agreements/washa gree_03011994.pdf(letöltés: 2012.08.05.)

Zakon o zaštiti prava pripadnika nacionalnih manjina. [2003] Ombudsman Hivatala. Forrás:

http://www.ombudsmen.gov.ba/odjeli/Zakon\%20o\%20zastiti\%20prava\%20 nacionalnih\%20manjina\%20-\%20S1.\%20glasnik\%20BiH\%2012-03.pdf (letöltés: 2012.07.19.) 


\section{A SZERZŐ TÉMÁBAN MEGJELENT PUBLIKÁCIÓI}

\section{Tanulmány, analitika:}

Az európai muszlim közösségek sajátos színfoltja: a balkáni muszlimok. In: Rostoványi Zsolt (szerk.): Az iszlám Európában. Az európai muszlim közösségek differenciáltsága. Budapest, Aula, 2010, 447-485. old.

Egy „többségben levő kisebbség”, a boszniai muszlimok identitásának formálódása. Acta Humana, 2009/4. sz. 131-144. old.

A nyugat-balkáni uniós stratégia fejlődési irányai: stabilizáció és/vagy csatlakozás?

In: 60 éves Közgáz. A Jubileumi Tudományos Konferencia alkalmából készült tanulmányok: Társadalomtudományi Kar. Budapest, Aula, 2008. 155-171. old.

Független Koszovó - de milyen (áron)?

Szabad Ötletek. A szegedi bölcsészlap, 4. évf., 2007. 3. sz., 8. old.

A délszláv háborúk.

Rubicon, 17. évf., 2006. 2-3. sz., 66-77. old.

Háborús bünösök felelősségre vonása az egykori Jugoszláviában, Ruandában és Sierra Leonéban. Az ad hoc büntetőbíróságok gyakorlata.

Acta Humana, 13. évf. 2002. 46-47. sz., 47-64. old.

Egy felbomlási folyamat margójára. A Jugoszláv Szocialista Szövetségi Köztársaság megszünésének nemzetközi körülményei.

In: Rostoványi Zsolt (szerk.): Ars Boni et cequi. Tanulmányok az ezredvég nemzetközi rendszeréről. Bokorné Szegö Hanna 75. születésnapjára. Budapest, Nemzetközi Kapcsolatok Tanszék, 2000. 358-371. old.

Vita az ENSZ Közgyülés elött: Az emberé vagy az államé az elsőbbség? Acta Humana, 1999/37-38. 162-169. old.

\section{Szerkesztés (könyv, tankönyv):}

Bokorné Szegő Hanna - Böszörményi Jenő - Kemenszky Ágnes: Nemzetközi kapcsolatok alapszótár. Budapest, Aula Kiadó, 2003

Horváth Jenő (szerk.): A klasszikus hidegháború időszaka 1945-1962. Diplomáciatörténeti szöveggyüjtemény. Budapest, BKÁE Nemzetközi Kapcsolatok Tanszék, 2001. Társszerkesztők: Csicsmann László, Ignáth Éva, Kemenszky Ágnes 


\section{Recenzió, lexikon:}

The Hidden Handshake: National Identity and Europe in the Post-Communist World, by A. Debeljak.

Book review.

Journal of Common Market Studies, 44 (2) June 2006

Horváth Jenő (szerk.): Világpolitikai lexikon (1945-2005). Budapest, Osiris, 2005. 